Historic, archived document

Do not assume content reflects current scientific knowledge, policies, or practices. 

USDA United States Department of Agriculture

Forest Service

Northeastern

Research Station

Resource Bulletin NE-145

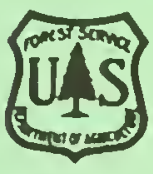

\section{Forest Statistics for Vermont: 1983 and 1997}

\author{
Thomas Frieswyk \\ Richard Widmann
}

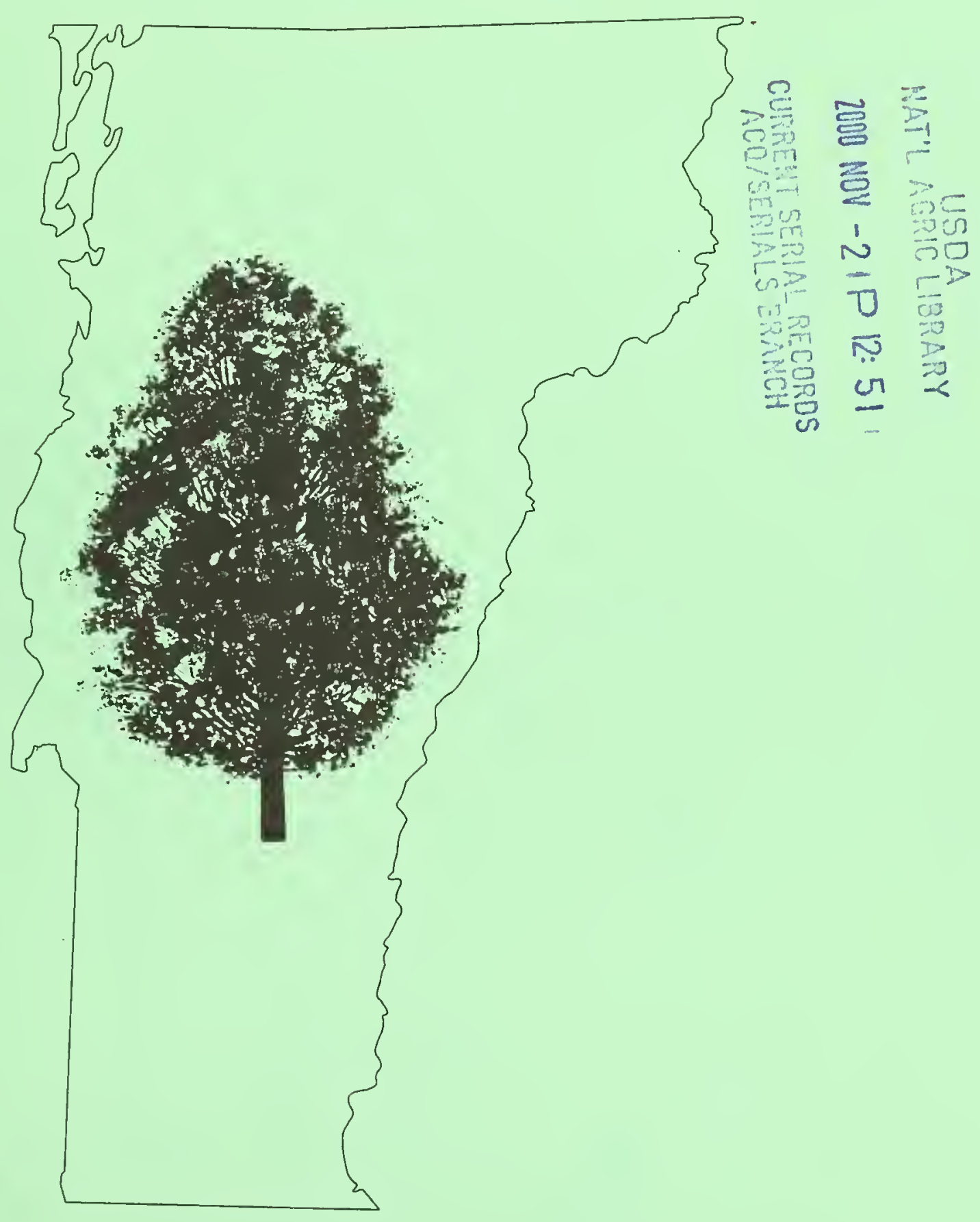




\begin{abstract}
A statistical report on the fifth forest inventory of Vermont conducted in 1996-98 by the Forest Inventory and Analysis Unit of the Northeastern Research Station. Statistics for forest area, numbers of trees, tree biomass, timber volume, growth, and change are displayed at the state and, where appropriate, the county level. The current inventory indicates that there are approximately 8.7 billion cubic feet of growing-stock volume on 4.5 million acres of timberland in Vermont.
\end{abstract}

\title{
Foreword
}

The fifth inventory of Vermont was directed by John R. Peters, Project Leader of the Forest Inventory and Analysis Unit. David J. Alerich supervised the data collection phase of the inventory. He was assisted by Robert E. Ilgenfritz, Richard A. McCullough, and Lucretia B. Stewart, and Kathryn M. Tillman at unit headquarters in Radnor, PA; and by Edward A. Doane, Brian M. LaPoint, Jason W. Morrison, and Scott H. Tepke, who coordinated the activities of the following members of the data-collection field staff in Vermont:

Michael A. Baer
Joseph P. Barsky
David Beers
David Berger
Karl J. Benner
Gabriel Bolton
Christopher W. Brown
Lynn D. Brown
Neal Bungard
Allison M. Bush
Elizabeth A. Burrill
Thomas M. Byron
Amy L. Calehuff
Jason Carter

Shane A. Carter
Paul F. Catanzaro
James D. Donaldson
Gene Dressley
Michael Effinger
Gerald Farrell
Robert Goodwin
Michael Haldeman
Jeffery Harriman
Keith G. Kanoti
Brian LaPoint
Michael J. Lingley
Benjamin Malone
Victoria Mas

James P. Morin Seth Partridge Neil Pederson Andrew Reed Laurie Reid Daniel Schultz Jerome S. Scott Michael Ulsh Dean Wargo Mike Whitehill Christine Ziegler

Carol Alerich and Tom Frieswyk applied FINSYS (Forest Inventory SYStem), a generalized data processing system, ORACLE SQLPlus, and SAS to process and analyze the information provided by the field crews, and produced summary tables of estimates and errors for the state and counties. Doug Griffith, Richard Goren, and Michael Kazimer assisted in data entry and data management.

Bob DeGeus, along with other members of the Vermont Department of Forests, Parks and Recreation, collected and compiled data on public ownership and assisted in reviewing this document for accuracy. Thom J. McEvoy of the University of Vermont also assisted in reviewing this document.

Vickie M. Sharon was responsible for administrative and secretarial services.

The Forest Inventory and Analysis Unit thanks the landowners of Vermont and the Vermont State Department of Forests, Parks and Recreation for their cooperation and assistance during this inventory. 


\title{
Forest Statistics for Vermont: 1983 and 1997
}

\author{
Thomas Frieswyk, Forester \\ Richard Widmann, Forester
}

\author{
Forest Inventory and Analysis Unit \\ Northeastern Research Station \\ USDA Forest Service \\ Newtown Square, PA
}

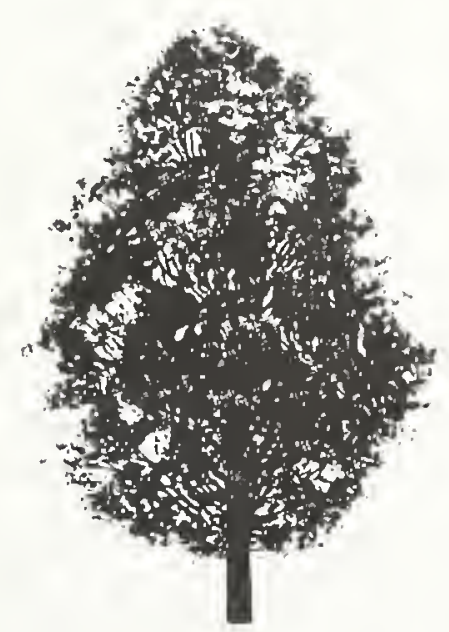

Visit our homepage at: http://www.fs.fed.us/ne

\begin{tabular}{ll}
\hline \hline Published by: & For additional copies: \\
USDA FOREST SERVICE & USDA Forest Service \\
11 CAMPUS BLVD SUITE 200 & Publications Distribution \\
NEWTOWN SQUARE PA 19073-3294 & 359 Main Road \\
September 2000 & Delaware, OH 43015-8640 \\
\hline \hline
\end{tabular}

Manuscript received for publication 10 April 2000 



\section{Contents}

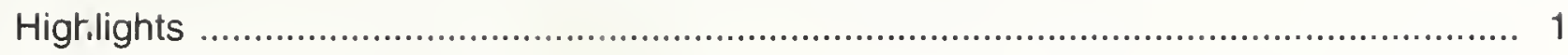

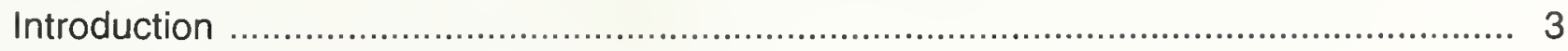

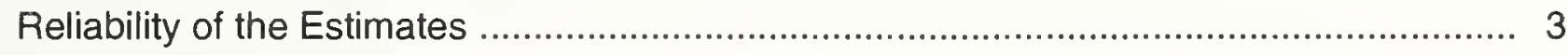

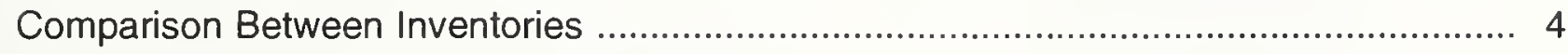

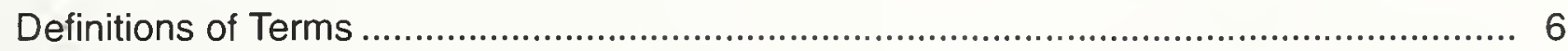

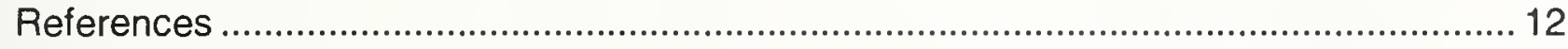

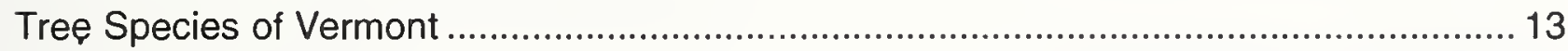

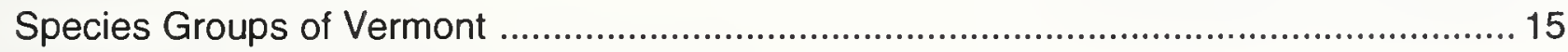

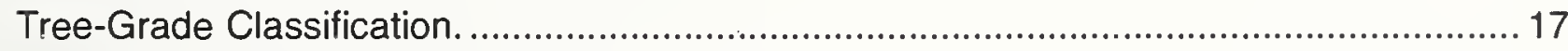

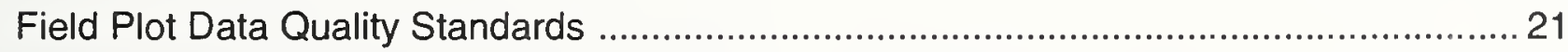

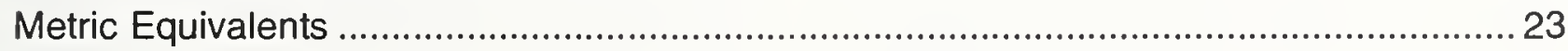

Index to Tables

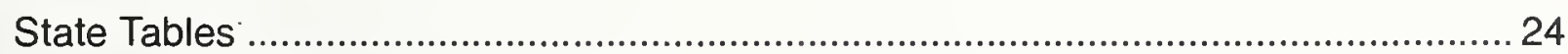

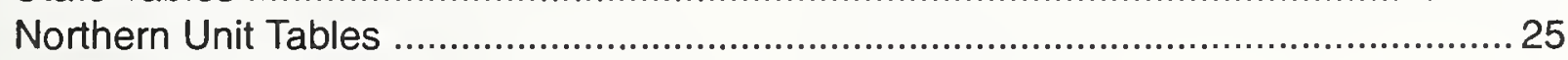

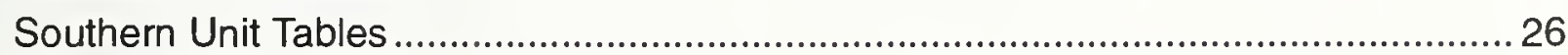

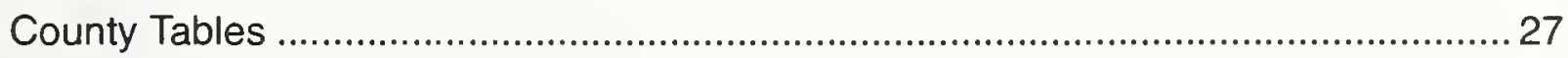

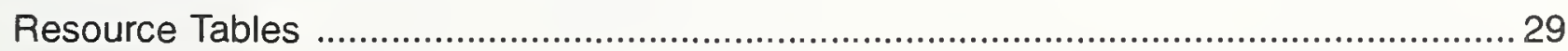





\section{Highlights}

\section{Forest-land Area}

Forests cover 4.6 million acres or 78.2 percent of Vermont. This is an increase of 93,000 acres since the previous forest inventory in 1983. Timberland area increased by 69,600 acres and other forest land increased by 23,300 acres. Timberland area represents 97 percent of total forest-land area.

(Thousands of acres at each inventory)

\begin{tabular}{|l|r|r|r|r|r|}
\hline & \multicolumn{1}{|c|}{1948} & \multicolumn{1}{c|}{1966} & \multicolumn{1}{c|}{1973} & 1983 & 1997 \\
\hline Timberland & $3,713.4$ & $4,294.6$ & $4,429.9$ & $4,412.9$ & $4,482.5$ \\
\hline $\begin{array}{l}\text { Other } \\
\text { forest land }\end{array}$ & 16.3 & 27.1 & 63.8 & 123.0 & 146.3 \\
\hline $\begin{array}{l}\text { Total } \\
\text { forest land }\end{array}$ & $3,729.7$ & $4,321.7$ & $4,493.7$ & $4,535.9$ & $4,628.8$ \\
\hline $\begin{array}{l}\text { Percent } \\
\text { forested }\end{array}$ & $62.8 \%$ & $72.8 \%$ & $75.7 \%$ & $76.6 \%$ & $78.2 \%$ \\
\hline $\begin{array}{l}\text { Estimated total } \\
\text { land area* }\end{array}$ & $5,937.9$ & $5,937.0$ & $5,935.4$ & 5919.6 & $5,919.0$ \\
\hline
\end{tabular}

"Estimates of the total land area have changed because of new measurement techniques and refinements in the classification of small bodies of water and streams.

Sawtimber-size stands increased by 21 percent and now account for 61 percent of the timberland.

Poletimber-size stands declined by 26 percent and now represent 29 percent of timberland. The area in sapling/seedling and nonstocked stands accounts for 10 percent of the timberland. Area in these conditions increased by 16 percent since the previous inventory.

Area of timberland by stand-size class

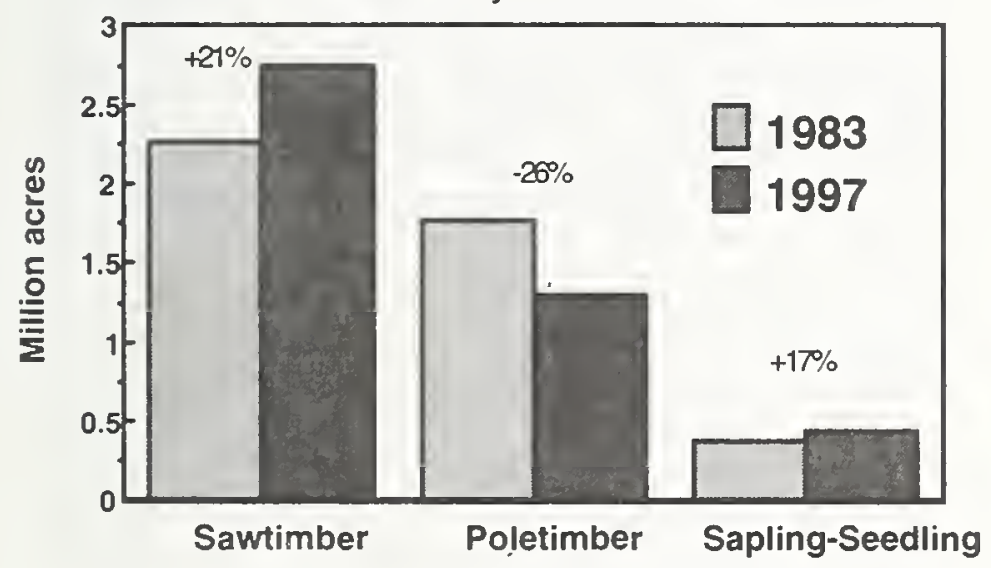

\section{Volume}

The total volume of all live trees on timberland 5 inches and larger in diameter increased by 20.5 percent. Growing-stock volume increased by 33.3 percent, 26.2 percent in the Northern Unit and by 40.0 percent in the Southern Unit. The portion of volume suitable for sawlogs increased by 47.4 percent.

\section{Growing-stock volume}

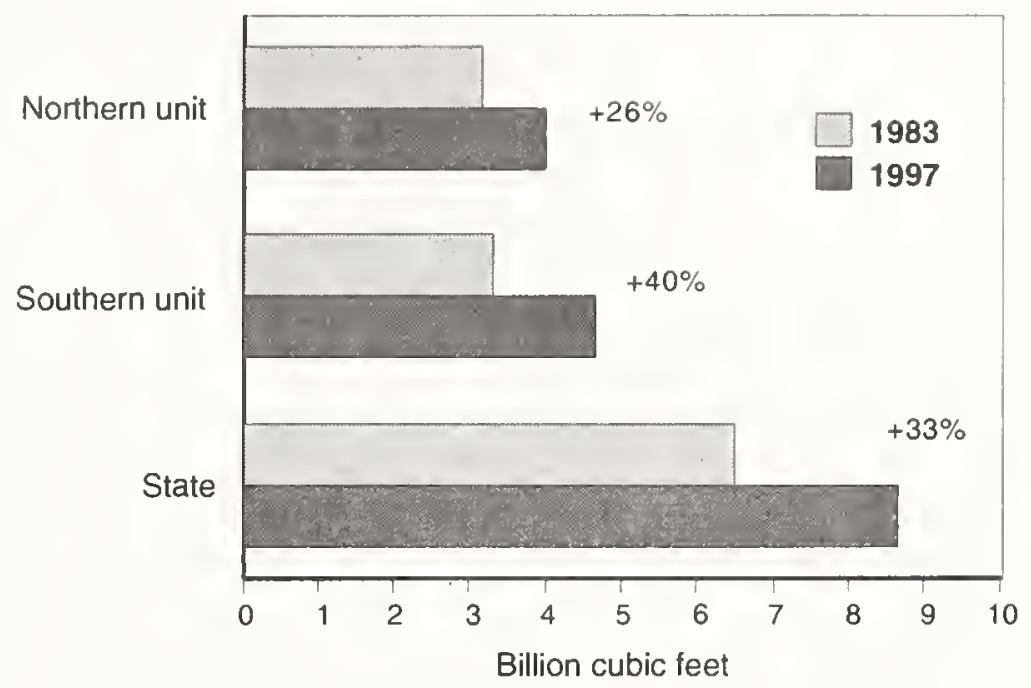

Sugar maple continued to have the greatest volume, leading all other species. Growing-stock volume of sugar maple, red maple, and hemlock increased by, 31.0, 54.4, and 53.2 percent, respectively. These species account for 52.2 percent of the increase in volume between inventories.

Change in growing-stock volume, top five species

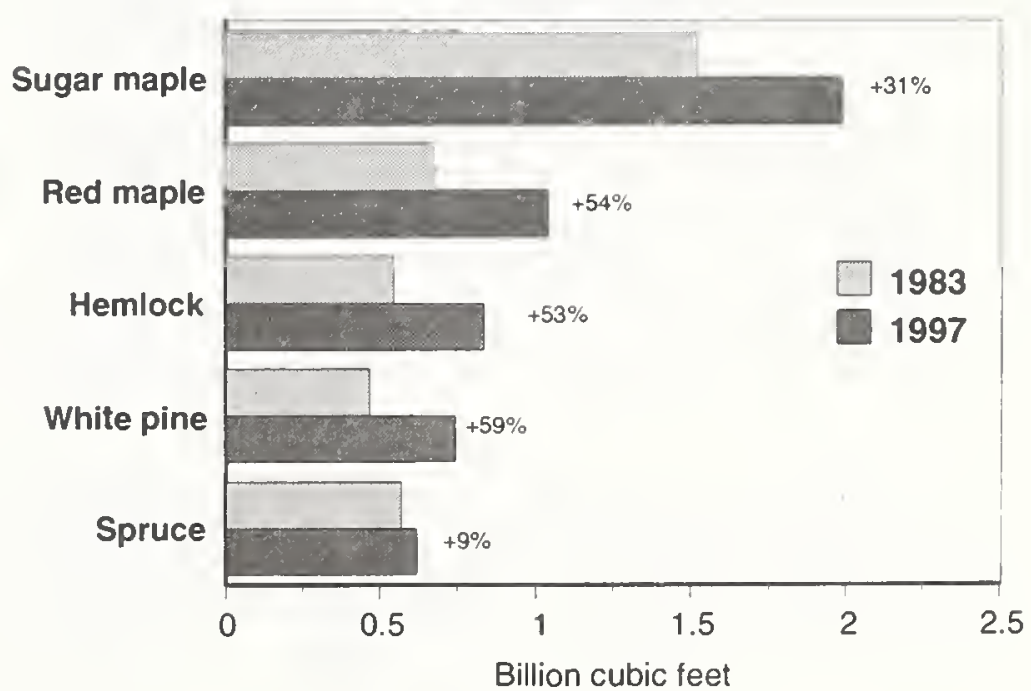




\section{Growth and Removals}

On an annual basis, net growth of growing stock on Vermont's timberland has averaged 189.8 million cubic feet of wood and the average annual harvest plus other removals has been 81.8 million cubic feet. The ratio of net growth to removals has averaged about $2.3: 1$ over the past inventory period.

On an annual basis, mortality has averaged ( 47.8 million cubic feet) 0.6 percent of the current inventory.
Average annual net growth and removals of growing stock, top five species

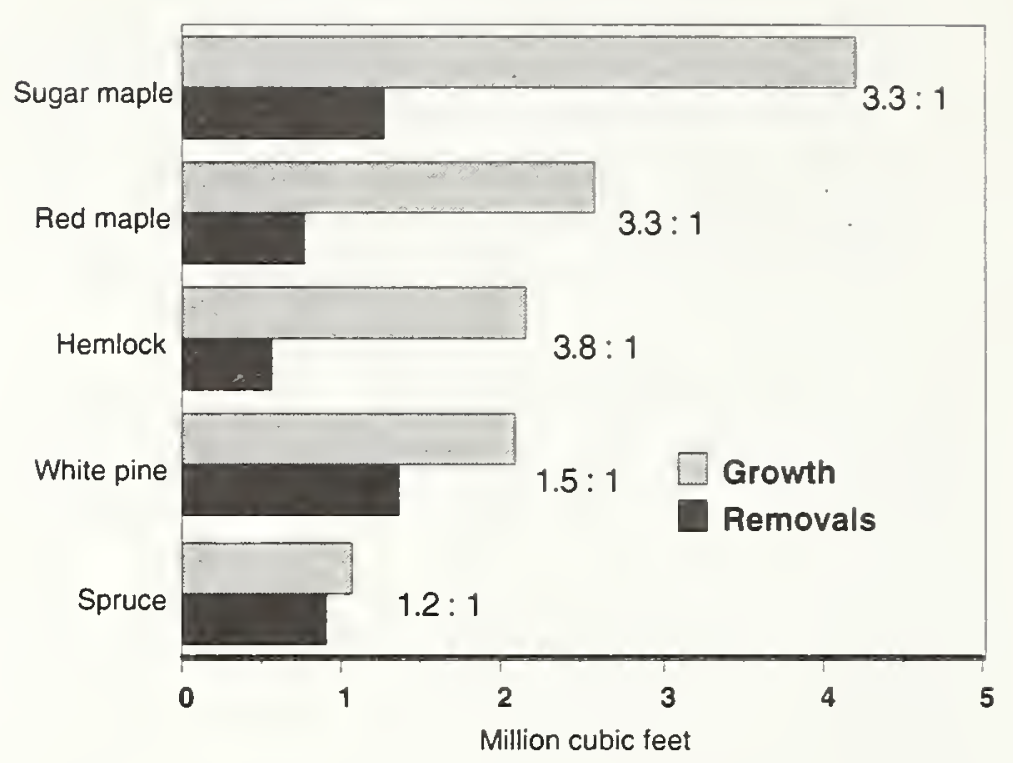




\section{Introduction}

Under the authority of the McSweeney-McNary Forest Research Act of 1928 and subsequent acts, including the Renewable Resources Planning Act of 1974 and the Renewable Resources Research Act of 1978, the USDA Forest Service conducts periodic inventories of all states to provide up-to-date information on the forest resources of the Nation. The initial inventory of Vermont's forest resources was conducted in 1948. Succeeding inventories were carried out in 1966, 1973, and 1983. This report presents forest-resource data from the fifth inventory, which was conducted in 1996-98. This inventory was a cooperative effort of the Northeastern Research Station, the Vermont Department of Forests, Parks and Recreation, and the landowners of Vermont.

The Forest Inventory and Analysis Unit (FIA) of the Northeastem Research Station conducted the inventory on all lands, developed the resource tables, and prepared this report.

The sampling procedure used during the current inventory included the use of aerial photography, the remeasurement of a sample of ground plots established in earlier inventories, and the establishment of new ground plots. For Vermont, this procedure required the photointerpretation and classification of 21,976 new photo points and 823 previously sampled ground plot locations into land-use and cubicfoot volume classes. Then 823 ground plots from the previous inventory were remeasured and 103 new ground plots were established. Of the total 926 plots, 724 were forested at plot center. The data collected were summarized using the FINSYS computer system developed at the Northeastern Research Station.

In January of 1998, a series of ice storms in northern New England and New York damaged an estimated 940,000 acres in Vermont. Five counties were declared disaster areas. FIA was asked to reinventory the area that was thought to be most severely impacted. During the spring and summer of 1998,118 plots were selected and remeasured within the damage footprint identified by the State of Vermont. The entire inventory was reprocessed incorporating the updated data from the damage footprint. As per agreement with the State of Vermont only one set of inventory data will be available and that data will contain the ice damage update.

The resurvey of Vermont's forest resources involved several associated studies and considerable analysis. Reports on the state's private forest-land owners and its primary forest-products industry also will be available, and a report analyzing Vermont's forest resource in greater detail is being prepared.

The forest area, numbers of trees, biomass, timber volume, growth, and change statistics in this report summarize the information collected. Other information or additional summaries may be developed. For information about these, contact the Forest Inventory and Analysis Unit, USDA Forest Service, 11 Campus Boulevard, Suite 200, Newtown Square, PA 19073 (Telephone: 610-557-4075; Fax: 610$557-4200)$.

\section{Reliability of the Estimates}

The data in this report are based on a carefully designed sample of forest conditions throughout Vermont. However, because the field crews did not measure every tree or every acre in the state, the data are estimates. The reliability of the estimating procedure can be judged by two important statistical measures: accuracy and precision. Accuracy refers to the success of estimating the true value; while precision refers to the clustering of sample values about their own averages or to the variation among repeated samples. We are interested primarily in the accuracy of the inventory but in most cases we can only measure its precision.

Although accuracy cannot be measured exactly, it can be checked. Preliminary tables are sent to other agencies and to outside experts familiar with the forest conditions in Vermont. If questions arise, the data are reviewed and reanalyzed to resolve differences. Great care is taken to minimize sources of procedural error through careful training of both field and office personnel, frequent inspection of field and office work, and application of the most reliable inventory methods.

Because of the care exercised in the inventory process, estimates of precision afford a reasonable measure of the inventory's 
adequacy. The precision of each estimate is described by its sampling error. Sampling errors are given with several tables in this report. The others are available upon request.

Here is an example of how the sampling error is used to indicate reliability. The estimate of timberland for Vermont is $4,482,500$ acres. The associated sampling error is 1.0 percent, or 44,825 acres. This means that if there are no errors in the procedure, we are 68 percent confident that the true number of acres is between $4,437,675$ and $4,527,325$ acres, or $4,482,500 \pm 44,825$ (one standard deviation). Similarly, we are 95 percent confident that the true number of acres is within $\pm 89,650$ acres (two standard deviations). County estimates are less precise. In Vermont, for example, while the sampling error for timberland at the state level is 1.0 percent, the sampling error for Addison County is 7.4 percent. In general, as the size of the sample decreases, the sampling error, expressed as a percentage of the estimate, increases. A high amount of variance within a county increases the sampling error.

For many of the tables in this report, both the last column and last row are labeled "SE." These figures are the sampling errors of the column and row totals. The last sampling error given (SE) is for the table total. To calculate the approximate sampling error $\left(S E_{i j}\right)$ for a table cell (ij), use the following formula (this formula is reliable only for estimating sampling errors of individual cells in AREA tables):

$S E_{i j}=1 / P_{i j}\left(\left(P_{i j}\left(1-P_{i j}\right)\right) / n\right)^{1 / 2}$

where:

$n=$ total number of sample plots of a population

$P_{i j}=A_{i j} / A$

$A_{i j}=$ cell estimate

$A=$ total land area of a population

ij = row(i) and column(i)

Any estimate with a sampling error of 50 percent or more is not significantly different from zero, and estimates with errors of 25 to 50 percent are suspect. Therefore, any estimates with errors exceeding 25 percent should be used with caution.

\section{Comparison Between Inventories}

To evaluate the condition of the forest resource, it is useful to compare the current estimates with those from the previous inventory. However, as a result of ongoing efforts to improve the efficiency of the inventory, we have made several changes in procedures and definitions since 1980. Because these changes make inappropriate the direct comparison of some of the current estimates with those published by Frieswyk and Malley (1985), readers should use caution when comparing the data in this report with those in the 1983 report. In this report, several tables containing 1983 data are provided to allow comparisons. The changes in methods and definitions follow.

To improve data consistency at the national level, a standard plot design is being used by all Forest Inventory projects in the country. The new plot design, a cluster of four 24-foot-radius subplots covering a $1 / 6$-acre area, was established at this occasion at all selected plot locations, both new and previously measured. Field crews recorded different conditions on the plots if certain attributes (land use, forest type, stand origin, stand size, tree density, and/or owner) differed from those at plot center. They "mapped" these conditions by recording information that described the boundaries of the conditions. This mapping procedure is designed to reduce bias in the estimates. In previous inventories, a ground plot was established wholly within the land class (forest or nonforest) that the plot was chosen to represent. The condition (e.g. privately-owned northernhardwoods sawtimber timberland) that was found at plot center was used to classify the entire plot.

On all selected remeasured plot locations, a subsample of the trees that were recorded in the past were reconciled, and growth and removals estimates were calculated using these data. Condition mapping was ignored for calculations of estimates of change because this procedure was not used at the previous occasion.

Forest Inventory uses Bureau of Census estimates of total land area in a state or county as the basis for estimating land area by various 
classes. For the 1983 report (1985), 1980 Bureau of Census data were used; in 1997 , 1990 data were available. Between 1980 and 1990, the Bureau of Census changed its estimating procedures. It now can identify as inland water streams more than 200 feet wide and bodies of water 4.5 acres and larger in area. Previously, the minimum width was 660 feet for streams and the minimun area was 40 acres for bodies of water. This procedure results in a reduction in total land area. For comparison of land area between inventories, 1983 estimates of land area by class were recalculated using 1990 land-area values from the Bureau of Census.

Stocking is a quantitative expression of live tree stand density that may be expressed in absolute terms, such as basal area per acre, volume per acre, or number of trees per acre; or in relative terms, such as a percent of a previously defined standard (Arner et al., 2000). For the 1983 inventory statistics, the stocking value of a tree was calculated using the basal area of the tree as a percent of 75 square feet per acre, which is the basal area standard for full use of the site (Forest Survey Handbook, 1967). Basal area stocking may well describe current timber volume, but it is inadequate to describe stand composition in a multi-resource inventory in that it neither adequately measures present site utilization nor describes small-diameter stands. For the statistics in this publication, stocking is calculated using relative density, which represents site occupancy based on normal yield tables. Basal area is diameter-dependent only; whereas relative density reflects species composition, stage of development and the social position of the trees present. A relative measure of stand density is a useful tool for interpreting findings of extensive inventories, such as those performed by Forest Inventory and Analysis, where a wide variety of stands are sampled. A procedure using relative density to calculate stocking was developed and accepted as a standard to be used by all FIA projects in the country.

Stand size is a classification (sapling/seedling, poletimber, sawtimber, or nonstocked) of forest land based on the size of the trees that dominate an area, and forest type is a classification of forest land based on the species found in the area. Stand size and forest type are both calculated based on stocking of all live trees, and therefore are affected by the change in the procedure to calculate stocking. To allow comparisons, this report includes several 1983 area tables showing estimates of area of timberland by stand-size class and forest type and forest-type group that are calculated based on relative density. There are also tables that show estimates of timberland area by forest type and stand size for both 1983 and 1997, where stocking is based on the basal area of all live trees

Forest type is a classification of forest land based on species that form a plurality of livetree stocking. Prior to 1995, basal area was used to determine plurality of live-tree stocking. Currently, forest type classification is based on stocking values calculated using relative density. There have been minor refinements with respect to how several species (e.g. red maple and beech) are allocated to local types since the previous inventory and a programming error that affected the white pine type was corrected.

Eighty-nine percent of the plots that were visited during the 1997 inventory, were measured in 1983. The estimates of average annual net growth and change are derived from this set of data. These estimates afford an opportunity to look at change in overall volume from occasion to occasion and from plot to plot. The estimates showing 1983 information are from the plots that were selected at that occasion to produce an estimate of the area and volume.

\footnotetext{
1 Arner, Stanford L. et al. 2000. National Algorithms for Determining Stocking Class, Stand Size Class, and Forest Type for Forest Inventory and Analysis Plots. Unpublished document on file at Northeastern Research Station Forest Inventory and Analysis, 11 Campus Boulevard, Suite 200, Newtown Square, PA 19073.
}

\footnotetext{
2 Author unknown. 1967. Forest Survey Handbook. Unpublished document on file at Northeastern Research Station Forest Inventory and Analysis, 11 Campus Boulevard, Suite 200, Newtown Square, PA 19073.
} 
These data have been used in current procedures to recalculate estimates of area and volume at the 1983 occasion so that comparisons can be made. Although the data set from which estimates of growth and change are derived contains a portion of the plots from which the 1983 recalculated estimates were calculated, they are different data sets designed to produce different types of estimates. Inconsistencies in trends may result when the annual change tables are compared with the total change between the 1983 and 1997 tables. Sampling errors have been included to indicate the precision of the data.

In addition to the traditional data gathered to estimate forest area and tree volumes, information was collected to describe forest wild life habitat and forest-tree biomass.

\section{Definitions of Terms}

Acceptable tree. (a) Live sawtimber trees that do not qualify as preferred trees but are not cull trees. (b) Live poletimber trees that prospectively will not qualify as preferred trees, but are not now or prospectively cull trees.

Accretion. The estimated net growth on growing-stock trees that were measured during the previous inventory (divided by the number of growing seasons between surveys to produce average annual accretion). It does not include the growth on trees that were cut during the period, nor those trees that died.

Basal-area class. A classification of forest land based on basal area (cross-sectional area of a tree stem at breast height in square feet per acre) of all live trees of all sizes.

Board foot. A unit of lumber measurement 1 foot long, 1 foot wide, and 1 inch thick, or its equivalent. Intemational $1 / 4$ inch rule is used as the USDA Forest Service standard $\log$ rule in the eastem United States.

Board-foot stand-volume class. A classification of forest land based on net board-foot volume of sawtimber trees per acre.

Bog/Marsh/Swamp. Land that has less than 10.0 percent stocking with live trees and which characteristically supports low, generally herbaceous or shrubby vegetation, and which is intermittently covered with water during all seasons; includes tidal areas that are covered with brackish water duning high tides.

Commercial species. Tree species currently or prospectively suitable for industrial wood products; excludes species of typically small size, poor form, or inferior quality, such as hawthom and sumac.

Condition. A classification of a land area based on land use, forest type, stand onigin, and stand size (see definitions).

County and municipal lands. Lands owned by counties and local public agencies or municipalities or leased to them for 50 years or more.

Cropland. Land that currently supports agricultural crops including silage and feed grains, bare farm fields resulting from cultivation or harvest, and maintained orchards.

Cubic-foot stand-volume class. A classification of forest land based on net cubic-foot volume of all live trees per acre.

Cull decrement. The net volume of rough or rotten trees in the previous inventory that are classified as growing-stock trees in current inventory (divided by the number of growing seasons between surveys to produce average annual cull decrement).

\section{Cull tree. A rough tree or a rotten tree.}

Cull increment. The net volume of growing-stock trees in the previous inventory that are classified as rough or rotten trees in the current inventory (divided by the number of growing seasons between surveys to produce average annual cull increment).

Diameter at breast height (d.b.h.). The diameter outside bark of a standing tree measured at 4-1/2 feet above the ground.

Dry ton. A unit of measure of dry weight equivalent to 2,000 pounds or 907.1848 kilograms.

Dry ton stand-volume class. A classification of forest land based on net dry weight of the aboveground components of all live trees per unit area; usually expressed in dry tons per acre. 
Dry weight. The weight of wood and bark as it would be if it had been oven-dried; usually expressed in pounds or tons.

Farmer-owned lands. Lands owned by farm operators, whether part of the farmstead or not; excludes land leased by farm operators from nonfarm owners.

Federal lands. Lands (other than National Forests) administered by Federal agencies.

Forest industry lands. Lands owned by companies or individuals that operate primary wood-using plants.

Forest land. Land that is at least 10 percent stocked with trees of any size, or that formenly had such tree cover and is not currently developed for a nonforest use. The minimum area for classification of forest land is one acre. The components that make up forest land are timberland and all noncommercial forest land (see definitions).

Forest type. A classification of forest land based on the species that form a plurality of live-tree stocking.

Forest-type group. A classification of forest land based on the species forming a plurality of live-tree stocking. A combination of forest types that share closety associated species or site requirements are combined into the following major forest-type groups (the descriptions apply to forests in this state):

a. White/red pine. Forests in which eastem white pine, red pine, or eastem hemlock, singly or in combination, make up the plurality of the stocking; common associates include red maple, oak, sugar maple, and aspen.

b. Spruce/fir. Forests in which red, white, black, or Norway spruces, balsam fir, northem white-cedar, tamarack, or planted larch, singly or in combination, make up a plurality of the stocking; common associates include white pine, red maple, yellow birch, and aspens.

c. Hard pine (also called loblolly/shortleaf pine). Forests in which eastem redcedar or pitch pine, singly or in combination, make up a plurality of the stocking; common associates include white pine, paper birch, sugar maple, and basswood. d. Oak/pine. Forests in which hardwoods (usually hickory or upland oaks) make up a plurality of the stocking and in which pines or eastem redcedar contribute 25 to 50 percent of the stocking.

e. Oak/hickory. Forests in which upland oaks, hickory, yellow-poplar, black locust, sweetgum, or red maple (when associated with central hardwoods), singly or in combination, make up a plurality of the stocking and in which pines or eastem redcedar make up less than 25 percent of the stocking; common associates include white ash, sugar maple, and hemlock.

f. Oak/gum/cypress. Bottomland forests in which tupelo, blackgum, sweetgum, oaks, or southem cypress, singly or in combination, make up a plurality of the stocking and in which pines make up less than 25 percent of the stocking; common associates include cottonwood, willow, ash, elm, hackberry, and maple.

g. Elm/ash/red maple (also called elm ash /cottonwood). Forests in which elm, willow, cottonwood, or red maple (when growing on wet sites), singly or in combination, make up a plurality of the stocking; common associates include white ash, sugar maple, aspens, and oaks.

h. Northem hardwoods (also called maple/beech/birch). Forests in which sugar maple, beech, yellow birch, black chemy, or red maple (when associated with northem hardwoods), singly or in combination, make up a plurality of the stocking; common associates include white ash, eastem hemlock, basswood, aspens, and red oak.

i. Aspen/birch. Forests in which aspen, paper birch, or gray birch, singly or in combination, make up a plurality of the stocking; common associates include red maple, white pine, red oaks, and white ash.

Gross growth. The sum of accretion and ingrowth.

Growing-stock trees. Live trees of commercial species classified as sawtimber, poletimber, saplings, or seedlings; that is, all live trees of commercial species except rough and rotten trees.

Growing-stock volume. Net volume, in cubic feet, of growing-stock trees 5.0 inches d.b.h. and larger 
from a 1-foot stump to a minimum 4.0-inch top diameter outside bark of the central stem, or to the point where the central stem breaks into limbs. Net volume equals gross volume less deduction for cull.

Hard hardwoods. Hardwood species with an average specific gravity of greater than 0.50 .

Handwoods. Dicotyledonous trees, usually broad-leaved and deciduous.

Harvested cropland. All lands from which crops were harvested or hay was cut; all land in orchards, citrus groves, vineyards, and nursery and greenhouse products.

Idle farmland. Former cropland or pasture that has not been tended for within the last 2 years and has less than 10 percent stocking with live trees (established seedlings or larger trees), regardless of species.

Improved/maintained pasture. Land that is currently used and maintained for grazing (not including grazed cropland).

Indian lands. (a) Lands held in trust by the United States or States for Indian tribes or individual Indians. (b) Lands owned in fee by Indian tribes whether subject to Federal or State restrictions against alienation or not.

Industrial and commercial land. Supply yards, parking lots, factories, etc.

Ingrowth. The estimated net volume of growing-stock trees that became 5.0 inches d.b.h. or larger during the period between inventories (divided by the number of growing seasons between surveys to produce average annual ingrowth). Also, the estimated net volume of growing-stock trees 5.0 inches d.b.h. and larger that are growing on land that was reclassified from noncommercial forest land or nonforest land to timberland.

Intemational 1/4-inch rule. A log rule or formula for estimating the board-foot volume of logs. The mathematical formula is:

$$
\left(0.22 D^{2}-0.71 D\right)(0.904762)
$$

for 4-foot sections, where $D=$ diameter inside bark at the small end of the log section. This rule is used as the USDA Forest Service standard log rule in the Eastem United States.

Land area. (a) Bureau of Census: The area of dry land and land temporanily or partly covered by water, such as marshes, swamps, and river flood plains; streams, sloughs, estuaries, and canals less than 200 feet wide; and lakes, reservoirs, and ponds less than 4.5 acres in area. (b) Forest Inventory and Analysis: same as (a) except that the minimum width of streams, etc. is 120 feet, and the minimum size of lakes, etc. is 1 acre.

Land use. A classification of land that indicates the primary use at the time of inventory. Major categories are forest land and nonforest land (see definitions).

Merchantable stem. The main stem of the tree between a 1-foot stump height and a 4-inch top diameter (outside the bark), including the wood and bark.

Mining and waste land. Surface mining, gravel pits, dumps.

Miscellaneous private lands. Privately owned lands other than forest industry and farmer-owned lands.

Mortality. The estimated net volume of growing-stock trees at the previous inventory that died from natural causes before the current inventory (divided by the number of growing seasons between surveys to produce average annual mortality).

National Forest lands. Federal lands legally designated as National Forests or purchase units and other lands administered as part of the National Forest System by the USDA Forest Service.

Net change. The difference between the current and previous inventory estimates of growing-stock volume (divided by the number of growing seasons between surveys to produce average annual net change). Components of net change are ingrowth plus accretion, minus mortality, minus cull increment, plus cull decrement, minus removals.

Net dry weight. The dry weight of woody material less the weight of all unsound (rotten) material.

Net growth. The change, resulting from natural causes, in growing-stock volume during the period 
between surveys (divided by the number of growing seasons to produce average annual net growth). Components of net growth are ingrowth plus accretion, minus mortality, minus cull increment, plus cull decrement.

Noncensus water. Streams/rivers between 120 feet and 200 feet in width, and bodies of water between 1 and 4.5 acres in size. The Bureau of the Census classifies such water as land.

Noncommiercial forest land. Reserved productive forest land, Christmas tree plantations, other forest land, and other reserved forest land (see definitions).

Noncommercial species. Tree species of typically small size, poor form, or inferior quality that normally do not develop into trees suitable for industrial wood products.

Nonforest land. Land that has never supported forests, or land formenly forested but now in nonforest use such as cropland, pasture, residential areas, marshes, swamps, highways, industrial or commercial sites, or noncensus water.

Nonsalvable dead tree. A dead tree with most or all of its bark missing that is at least 5.0 inches d.b.h. and is at least 4.5 feet tall.

Nonstocked area. A stand-size class of forest land that is stocked with less than 10 percent of minimum full stocking with live trees.

Other cropland. Includes cropland used for cover crops and soil improvement (legumes).

Other farmland. All nonforest land on a farm excluding cropland, pasture, and idle farmland; includes farm lanes, stock pens, and farmsteads.

Other forest land. Forest land that is incapable of producing 20 cubic feet per acre per year of industrial wood under natural conditions, because of adverse site conditions (formerly known as unproductive forest land).

Other reserved forest land. Forest land that is incapable of producing 20 cubic feet per acre per year of industrial wood under natural conditions, because of adverse site conditions, and is protected through statute or administrative designation.
Ownership class. A classification of forest land based on ownership and nature of business or control of decisionmaking for the land. It encompasses all types of legal entities having ownership interest in the land, whether public or private.

Pasture land. Includes any pasture land other than cropland and woodland pasture. It can include lands that have had lime fertilizer or seed applied, or that had been improved by imigation, drainage, or control of weeds and brush.

Pastured cropland. Includes rotation pasture and grazing land that would have been used for crops without additional improvement.

Pastured timberland. Land that is partially developed, maintained, or managed for pasture and grazing, but which continues to meet the definition of timberland.

Poletimber stand. A stand-size class of forest land that is stocked with at least 10 percent of minimum full stocking with live trees with half or more of such stocking in poletimber or sawtimber trees or both, and in which the stocking of poletimber exceeds that of sawtimber.

Poletimber tree. A live tree of commercial species meeting regional specifications of soundness and form and at least 5.0 inches in d.b.h., but smaller than a sawtimber tree.

Preferred tree. A high-quality tree, from a lumber viewpoint, that would be favored in cultural operations. General characteristics include grade 1 butt log (if sawtimber size), good form, good vigor, and freedom from serious damage.

Recreation site. Parks, campgrounds, playing fields, tracks, etc.

Relative stand density. A stocking classification procedure that reflects species, stage of development, and the characteristics of the trees present in a stand.

Removals. The net growing-stock volume harvested or killed in logging, cultural operations (such as timber stand improvement) or land cleaning, and the net growing-stock volume neither harvested nor killed but growing on land that was reclassified from timberland to noncommercial forest land or nonforest land during the period between surveys. This volume is divided by the 
number of growing seasons to produce average annual removals.

Reserved productive forest land. Forest land sufficiently productive to qualify as timberland but withdrawn from timber utilization through statute or administrative designation; land exclusively used for Christmas tree production.

Rights-of-way. Highways, pipelines, powerlines, canals.

Rotten tree. A live tree of commercial species that does not contain at least one 12-foot sawlog or two noncontiguous sawlogs, each 8 feet or longer, now or prospectively, and does not meet regional specifications for freedom from defect primarily because of rot; that is, more than 50 percent of the cull volume in the tree is rotten.

Rough tree. (a)The same as a rotten tree except that a rough tree does not meet regional specifications for freedom from defect primarily because of roughness or poor form; also (b) a live tree of noncommercial species.

Salvable dead tree. A tree at least 5.0 inches d.b.h. that has died recently and still has intact bark; may be standing, fallen, windthrown, knocked down, or broken off.

Sampling error. A measure of the reliability of an estimate, expressed as a percentage of the estimate. The sampling errors given in this report correspond to one standard deviation and are calculated as the square root of the variance, divided by the estimate, and multiplied by 100 . Indicated in statistical tables as "SE".

Sapling. All live trees 1.0 through 4.9 inches d.b.h.

Sapling/seedling stand. A stand-size class of forest land that is stocked with at least 10 percent of minimum full stocking with live trees with half or more of such stocking in saplings or seedlings or both.

Sawlog. A log meeting regional standards of diameter, length, and freedom from defect, including a minimum 8-foot length and a minimum top diameter inside bark of 6 inches for softwoods and 8 inches for hardwoods. (See specifications under Tree-Grade Classification.)
Sawlog portion. That part of the bole of a sawtimber tree between the stump and the sawlog top.

Sawlog top. The point on the bole of a sawtimber tree above which a sawlog cannot be produced. The minimum sawlog top is 7.0 inches diameter outside bark (d.o.b.) for softwoods and 9.0 inches d.o.b. for hardwoods.

Sawtimber stand. A stand-size class of forest land that is stocked with at least 10 percent of minimum full stocking with all live trees with half or more of such stocking in poletimber or sawtimber trees or both, and in which the stocking of sawtimber is at least equal to that of poletimber.

Sawtimber tree. A live tree of commercial species at least 9.0 inches d.b.h. for softwoods or 11.0 inches for hardwoods, containing at least one 12-foot sawlog or two noncontiguous 8-foot sawlogs, and meeting regional specifications for freedom from defect.

Sawtimber volume. Net volume in boand feet, by the Intemational 1/4-inch rule, of sawlogs in sawtimber trees. Net volume equals gross volume less deductions for rot, sweep, and other defects that affect use for lumber.

\section{SE. See Sampling error.}

Seedling. A live tree less than 1.0 inch d.b.h. and at least 1 foot tall.

Single-family house. House sheltering one family and immediately adjacent managed land.

Snag. Standing dead tree with most or all of its bark missing that is at least 5.0 inches d.b.h. and at least 4.5 feet tall (does not include salvable dead).

Soft handwoods. Hardwood species with an average specific gravity of 0.50 or less.

Softwoods. Coniferous trees, usually evergreen and having needles or scalelike leaves.

Stand. A group of forest trees growing on forest land.

Stand origin. An indication of how the measured stand originated: 100 percent natural, 100 percent artificial, or a combination of both. 
Stand-size class. A classification of forest land based on the size class (that is, seedlings, saplings, poletimber, or sawtimber) of the stocking of all live trees in the area.

Standard cord. A unit of measure for stacked bolts of wood, encompassing 128 cubic feet of wood, bark, and air space. Fuelwood cord estimates can be derived from cubic-foot estimates of growing stock by applying an average factor of 80 cubic feet of solid wood per cord. For pulpwood, a conversion of 85 cubic feet of solid wood per cond is used because pulpwood is more uniform.

State lands. Lands owned by the state or leased to the state for 50 years or more.

Stocking. The degree of occupancy of land by trees relative to the growth potential utilized by a site. It' is expressed as a percent of the "normal" value presented in yield tables and stocking quides. Two categories of stocking are used in this report: all live trees and growing-stock trees. The relationships between the classes and the percentage of the stocking standard are: nonstocked (0 to 9 ); poorly stocked (10 to 34$)$; moderately stocked ( 35 to 59 ); fully stocked (60 to 100); and overstocked (greater than 100).

Strip mine. Area devoid of vegetation due to current or recent general excavation.

Stump. The main stem of a tree from ground level to 1 foot above ground level, including the wood and bark.

Timberland. Forest land producing or capable of producing crops of industrial wood (more than 20 cubic feet per acre per year) and not withdrawn from timber utilization (formerly known as commercial forest land).

Timber products. Roundwood (round timber) products and manufacturing plant by-products harvested from growing-stock trees on timberland; from other sources, such as cull trees, salvable dead trees, limbs, tops, and saplings; and from trees on noncommercial forest and nonforest lands.

Timber removals. The growing-stock or sawtimber volume of trees removed from the inventory for roundwood products, plus logging residues, volume destroyed during land clearing, and volume of standing trees on land that was reclassified from timberland to noncommercial forest land.

Top. The wood and bark of a tree above the merchantable height (or above the point on the stem 4.0 inches in diameter outside bark); generally includes the uppermost stem, branches, and twigs of the tree, but not the foliage.

Tract/multiple family housing. Multiple individual residential units or attached units (e.g., apartment buildings and condominiums) and immediately adjacent managed land.

Transportation night-of-way. Land associated with highways and railroads.

Tree class. A classification of the quality or condition of trees for sawlog production. Tree class for sawtimber trees is based on their current condition. Tree class for poletimber trees is a prospective determination-a forecast of their potential quality when they reach sawtimber size (11.0 inches d.b.h. for hardwoods, 9.0 inches d.b.h. for softwoods).

Tree grade. A classification of sawtimber quality based on guidelines for tree grades for hardwoods, white pine, and southem pine. (Note: Red pine was graded using the guidelines for southem pine. All specifications are shown under Tree-Grade Classification.)

Trees. Woody plants that have well-developed stems and that usually are more than 12 feet tall at maturity.

Unproductive forest land. See Other forest land.

Upper-stem portion. That part of the main stem or fork of a sawtimber tree above the sawlog top to a diameter of 4.0 inches outside bark, or to the point where the main stem or fork breaks into limbs.

Urban forest land. Forest land sufficiently productive to qualify as timberland that is completely surrounded by or nearly surrounded by urban development (not parks), whether commercial, industrial, or residential.

Utility right-of-way. Land associated with pipeline or electric transmission lines; identified only if vegetative cover differs from adjacent land use.

Veneer log or bolt. A roundwood product from which veneer is sliced or sawn that usually meets 
certain minimum standards of diameter, length, and defect.

Windbreak/hedgerow. Linear areas, less than 120 feet in width, with predominantly tree and/or shrub vegetation.
Volume suitable for pulpwood. The sound volume (only rotten cull excluded) of growing-stock and rough trees.

\section{References}

Frieswyk, Thomas S.; Malley, Anne M. 1985. Forest statistics for Vermont-1973 and 1983. Resour. Bull. NE-87. Broomall, PA: U.S. Department of Agriculture, Forest Service, Northeastern Forest Experiment Station. $102 \mathrm{p}$.

Kingsley, Neal P. 1977. The forest resources of Vermont. Resour. Bull. NE-46. Upper Darby, PA: U.S. Department of Agriculture, Forest Service, Northeastern Forest Experiment Station. 58 p.

Kingsley, Neal P.; Barnard, Joseph E. 1968. The timber resources of Vermont. Resour. Bull. NE-12. Upper Darby, PA: U.S. Department of Agriculture, Forest Service, Northeastern Forest Experiment Station. 117 p.

Lund, H. Gyde (ed.). 1998. IUFRO Guidelines for Designing Multipurpose Resource Inventories: A Project of IUFRO Research Group 4.02.02. IUFRO World Series, Vol. 8. Vienna, Austria: IUFRO. $216 \mathrm{p}$.

McGuire, John R.; Wray, Robert D. 1952. The forest statistics for Vermont. Upper Darby, PA: U.S. Department of Agriculture, Forest Service, Northeastern Forest Experiment Station. 47 p.

Scott, Charles T. 1979. Northeastern forest survey board-foot volume equations. Res. Note NE271. Broomall, PA: U.S. Department of Agriculture, Forest Service, Northeastern Forest Experiment Station. $3 p$.

Scott, Charles T. 1981. Northeastern forest survey revised cubic-foot volume equations. Res. Note NE-304. Broomall, PA: U.S. Department of Agriculture, Forest Service, Northeastern ForestExperiment Station. $3 \mathrm{p}$.

Wharton, Eric H.; Griffith, Douglas M. 1998. Estimating total forest biomass in Maine, 1995. Resour. Bull. NE-142 Radnor, PA: U.S. Department of Agriculture, Forest Service, Northeastern Forest Experiment Station. 50p. 


\section{Tree Species of Vermont (as encountered on field plots)}

\section{Scientific Name ${ }^{* \star *}$}

Common Name(s)

Occurrence $^{\star \star}$

\section{Softwoods}

Abies balsamea (L.) Mill.

Juniperus virginiana $L$.

Lanix sp. Mill.

Lanix laricina (Du Roi) K. Koch

Picea abies (L.) Karst.

Picea glauca (Moench) Voss

Picea maniana (Mill.) B.S.P.

Picea rubens Sarg.

Pinus resinosa Ait.

Pinus strobus $L$.

Pinus sylvestris L.

Thuja occidentalis L.

Tsuga canadensis (L.) Carr.

Acer pensylvanicum $\mathrm{L}$. *

Acer rubrum L.

Acer saccharinum $\mathrm{L}$.

Acer saccharum Marsh.

Acer spicatum Lam. *

Amelanchier sp. Medic. *

Betula alleghaniensis Britton

Betula lenta L.

Betula papyrifera Marsh.

Betula populifolia Marsh. *

Carpinus caroliniana Walt. *

Carya sp. Nutt.

Carya cordiformis (Wangenh.) K. Koch

Carya glabra (Mill.) Sweet

Carya ovata (Mill.) K. Koch

Carya tomentosa (Poir.) Nutt.

Crataegus sp. L.

Fagus grandifolia Ehrh.

Fraxinus americana L.

Fraxinus nigra Marsh.

Fraxinus pennsylvanica Marsh.

Juglans cinerea L.

Malus sp. Mill. *

Ostrya virginiana (Mill.) K. Koch *

Populus balsamifera L.

Populus deltoides Bartr. ex Marsh.

Populus grandidentata Michx.

Populus tremuloides Michix. balsam fir

eastern redcedar

larch (introduced)

tamarack (native)

Nonway spruce

white spruce

black spruce

red spruce

red pine

eastern white pine

Scotch pine

northern white-cedar

eastern hemlock

\section{Hardwoods}

striped maple

red maple

silver maple

sugar maple

mountain maple

serviceberry

yellow birch

sweet birch

paper birch

gray birch

American hornbeam

hickory

bitternut hickory

pignut hickory

shagbark hickory

mockernut hickory

hawthorn

American beech

white ash

black ash

green ash

butternut

apple

eastern hophornbeam

balsam poplar

eastern cottonwood

bigtooth aspen

quaking aspen vc

$\mathrm{vr}$

vr

$r$

$r$

c

$\mathrm{vr}$

ve

$r$

vc

vr

c

vc

c

vc

$r$

ve

$\mathrm{vr}$

$r$

vc

c

ve

$r$

vr

vr

$r$

vr

$r$

vr

$r$

ve

$c$

$r$

$r$

$r$

$r$

c

$r$

$\mathrm{vr}$

$r$ 
Prunus pensylvanica L. f. "

Prunus serotina Ehrh.

Prunus virginiana $\mathrm{L}$. *

Quercus alba L.

Quercus bicolor Willd.

Quercus macrocarpa Michx.

Quercus prinus L.

Quercus rubra L.

Quercus velutina Lam.

Robinia pseudoacacia L.

Salix sp. L. *

Salix nigra Marsh.

Sorbus americana Marsh. *

Tilia sp. L.

Tilia americana L.

Uimus americana L.

pin cherry
black cherry
chokecherry
white oak
swamp white oak
bur oak
chestnut oak
northern red oak
black oak
black locust
willow
black willow
American mountain-ash
basswood
American basswood
American elm

$r$

c

$\mathrm{vr}$

$r$

vr

$\mathrm{Vr}$

$r$

c

vr

vr

$\mathrm{vr}$

$v r$

$r$

vr

$r$

$r$

\footnotetext{
*\# Names according to: Little, Elbert L., Jr. 1979. Checklist of United States Trees (native and naturalized). Agric. Handb. 541. Washington, DC: U.S Department of Agriculture. 375 p.

* Occurrence is based on the proportion of the species among all live trees 5.0 inches d.b.h. or larger encountered on forest survey field plots: $\mathrm{vr}=$ very rare $(<0.05 \%), r=$ rare $(0.05$ to $0.49 \%), c=$ common $(0.5$ to $4.9 \%)$, and $v c=$ very common $(>5.0 \%)$.

* Noncommercial species.
} 


\section{Species Groups of Vermont}

\begin{tabular}{|c|c|c|}
\hline Species Group & Scientific name & Common name \\
\hline Baisam fir & Abies balsamea & balsam fir \\
\hline Tamarack & $\begin{array}{l}\text { Lanix sp. } \\
\text { Lanix lancina }\end{array}$ & $\begin{array}{l}\text { larch (introduced) } \\
\text { tamarack (native) }\end{array}$ \\
\hline White spruce & Picea glauca & white spruce \\
\hline Black spruce & Picea mariana & black spruce \\
\hline Red spruce & Picea rubens & red spruce \\
\hline Red pine & Pinus resinosa & red pine \\
\hline White pine & Pinus strobus & eastern white pine \\
\hline Northern white-cedar & Thuja occidentalis & northern white-cedar \\
\hline Hemiock & Tsuga canadensis & eastern hemlock \\
\hline Other softwoods & $\begin{array}{l}\text { Chamaecyparis thyoides } \\
\text { Juniperus virginiana } \\
\text { Picea abies } \\
\text { Pinus sylvestris }\end{array}$ & $\begin{array}{l}\text { Atlantic white-cedar } \\
\text { eastern redcedar } \\
\text { Norway spruce } \\
\text { Scotch pine }\end{array}$ \\
\hline Sugar maple & Acer saccharum & sugar maple \\
\hline Red maple & $\begin{array}{l}\text { Acer rubrum } \\
\text { Acer saccharinum }\end{array}$ & $\begin{array}{l}\text { red maple } \\
\text { silver maple }\end{array}$ \\
\hline Yellow blrch & Betula alleghaniensis & yellow birch \\
\hline Paper birch & Betula papyrifera & paper birch \\
\hline Beech & Fagus grandifolia & American beech \\
\hline White ash & Fraxinus americana & white ash \\
\hline Black ash & Fraxinus nigra & black ash \\
\hline Aspen & $\begin{array}{l}\text { Populus balsamifera } \\
\text { Populus deltoides } \\
\text { Populus grandidentata } \\
\text { Populus tremuloides }\end{array}$ & $\begin{array}{l}\text { balsam poplar } \\
\text { eastern cottonwood } \\
\text { bigtooth aspen } \\
\text { quaking aspen }\end{array}$ \\
\hline
\end{tabular}




\section{Species Groups of Vermont (continued)}

\begin{tabular}{|c|c|c|}
\hline Species Group & Scientific name & Common name \\
\hline White oaks & $\begin{array}{l}\text { Quercus albe } \\
\text { Quercus bicolor } \\
\text { Quercus macrocarpa } \\
\text { Quercus prinus }\end{array}$ & $\begin{array}{l}\text { white oak } \\
\text { swamp white oak } \\
\text { bur oak } \\
\text { chestnut oak }\end{array}$ \\
\hline Red oaks & $\begin{array}{l}\text { Quercus rubra } \\
\text { Quercus velutina }\end{array}$ & $\begin{array}{l}\text { northern red oak } \\
\text { black oak }\end{array}$ \\
\hline Basswood & Tilia americana & American basswood \\
\hline Elm & $\begin{array}{l}\text { Ulmus americana } \\
\text { Ulmus rubra }\end{array}$ & $\begin{array}{l}\text { American elm } \\
\text { slippery elm }\end{array}$ \\
\hline Other hardwoods & $\begin{array}{l}\text { Acer sp. } \\
\text { Acer pensylvanicum } \\
\text { Acer spicatum } \\
\text { Ailanthus altissima } \\
\text { Amelanchier sp. } \\
\text { Betula lenta } \\
\text { Betula populifolia } \\
\text { Carpinus caroliniana } \\
\text { Carya sp. } \\
\text { Carya cordiformis } \\
\text { Carya glabra } \\
\text { Carya ovata } \\
\text { Carya tomentosa } \\
\text { Comus florida } \\
\text { Crataegus sp. } \\
\text { Fraxinus pennsylvanica } \\
\text { Gleditsia triacanthos } \\
\text { Juglans cinerea } \\
\text { Juglans nigra } \\
\text { Malus sp. } \\
\text { Ostrya virginiana } \\
\text { Prunus pensylvanica } \\
\text { Prunus serotina } \\
\text { Prunus virginiana } \\
\text { Robinia pseudoacacia } \\
\text { Salix sp. } \\
\text { Salix nigra } \\
\text { Sorbus americana } \\
\text { Sorbus aucuparia } \\
\text { Tilia sp. }\end{array}$ & $\begin{array}{l}\text { maple } \\
\text { striped maple } \\
\text { mountain maple } \\
\text { ailanthus } \\
\text { serviceberry } \\
\text { sweet birch } \\
\text { gray birch } \\
\text { American hornbeam } \\
\text { hickory } \\
\text { bitternut hickory } \\
\text { pignut hickory } \\
\text { shagbark hickory } \\
\text { mockernut hickory } \\
\text { flowering dogwood } \\
\text { hawthorn } \\
\text { green ash } \\
\text { honeylocust } \\
\text { butternut } \\
\text { black walnut } \\
\text { apple } \\
\text { eastern hophornbeam } \\
\text { pin cherry } \\
\text { black cherry } \\
\text { chokecherry } \\
\text { black locust } \\
\text { willow } \\
\text { black willow } \\
\text { American mountain-ash } \\
\text { European mountain-ash } \\
\text { basswood } \\
\text { unknown or not listed tree }\end{array}$ \\
\hline
\end{tabular}


HARDWOOD TREE GRADES

\begin{tabular}{|c|c|c|c|}
\hline GRADING FACTOR & TREE GRADE 1 & TREE GRADE 2 & TREE GRADE 3 \\
\hline Length of grading zone (feet) & Butt 16 & Butt 16 & Butt 16 \\
\hline Length of grading section ${ }^{a}$ (feet) & Best 12 & Best 12 & Best 12 \\
\hline Minimum DBH (inches) & $16^{b}$ & 13 & 11 \\
\hline $\begin{array}{l}\text { Minimum Diameter inside bark at top } \\
\text { of grading section (inches) }\end{array}$ & $13^{b} 1620$ & $11^{\mathrm{c}} \quad 12$ & 8 \\
\hline Clear cuttings on 3 rd best face ${ }^{d}$ & & & \\
\hline minimum length (feet) & $\begin{array}{lll}7 & 5 & 3\end{array}$ & 3 & 2 \\
\hline number on face (maximum) & 2 & 2 & unlimited \\
\hline yield in face length (minimum) & $5 / 6$ & $4 / 6$ & $3 / 6$ \\
\hline $\begin{array}{l}\text { Cull deduction, including crook and } \\
\text { sweep but excluding shake, } \\
\text { maximum within grading section (\%) }\end{array}$ & 9 & $9^{e}$ & 50 \\
\hline
\end{tabular}

a Whenever a 14- or 16-foot section of the butt 16-foot log is better than the best 12-foot section, the grade of the longer section will become the grade of the tree. This longer section, when used, is the basis for determining the grading factors, such as diameter and cull deduction.

b In basswood and ash, diameter inside bark at the top of the grading section may be 12 inches and $\mathrm{DBH}$ may be 15 inches.

c Grade 2 trees can be 10 inches diameter inside bark at the top of the grading section if otherwise meeting surface requirements for small grade 1 's.

d A clear cutting is a portion of a face free of defects, extending the width of the face. A face is one-fourth of the surface of the grading section as divided lengthwise.

e Fifteen percent crook and sweep, or 40 percent total cull deduction are permitted in grade 2 if size and surface of grading section qualify as grade 1 . If rot shortens the required clear cuttings to the extent of dropping the butt log to grade 2, do not drop the tree's grade to 3 unless the cull deduction for rot is greater than 40 percent. 


\section{Tree-Grade Classification (continued)}

TIE AND TIMBER GRADE

\begin{tabular}{|c|c|}
\hline GRADE FACTORS & SPECIFICATIONS \\
\hline Position in tree & Butts and uppers \\
\hline Scaling Diameter (inches) & 8 inches d.i.b. and larger \\
\hline Length, without trim (feet) & 12 feet and larger \\
\hline Clear cuttings & no requirements: not graded on cutting basis \\
\hline Maximum sweep allowance & $\begin{array}{l}\text { One-fourth d.i.b. of small end for half logs, and one- } \\
\text { half d.i.b. for logs sixteen feet long }\end{array}$ \\
\hline $\begin{array}{l}\text { Sound surface defects permitted } \\
\text { Single knots }\end{array}$ & $\begin{array}{l}\text { Any number, if none has an average collar }{ }^{a} \text { diameter } \\
\text { that is more than one third of the log diameter at the } \\
\text { point of occurrence }\end{array}$ \\
\hline $\begin{array}{l}\text { Sound surface defects permitted } \\
\text { Whorled knots }\end{array}$ & $\begin{array}{l}\text { Any number, provided the sum of the collar } \\
\text { diameters does not exceed one third the log } \\
\text { diameter at the point of occurrence }\end{array}$ \\
\hline $\begin{array}{l}\text { Sound surface defects permitted } \\
\text { Knots }\end{array}$ & $\begin{array}{l}\text { Any number not exceeding knot specifications, if } \\
\text { they do not extend more than } 3 \text { inches into the } \\
\text { contained tie or timber }\end{array}$ \\
\hline Unsound surface defects permitted ${ }^{b}$ & $\begin{array}{l}\text { Any number and size if they do not extend into } \\
\text { contained tie or timber. If they extend into the } \\
\text { contained tie or timber, they shall not exceed size, } \\
\text { number, and depth of limits for sound defects. }\end{array}$ \\
\hline
\end{tabular}

a Knot collar is the average of the vertical and horizontal diameters of the limb, or knot swelling, as measured flush with the surface of the log.

b Interior defects are not visible in standing trees. They are considered in grading cut logs. No interior defects are permitted except one shake not more than one-third the width of the contained tie or timber, and one split not more than 5 inches long. 


\section{Tree-Grade Classification (continued)}

EASTERN WHITE PINE TREE GRADE SPECIFICATIONS

\begin{tabular}{|c|c|c|c|c|}
\hline $\begin{array}{l}\text { GRADING } \\
\text { FACTOR }\end{array}$ & TREE GRADE 1 & TREE GRADE 2 & TREE GRADE 3 & TREE GRADE 4 \\
\hline $\begin{array}{l}\text { (1) Minimum DBH } \\
\text { (inches) }\end{array}$ & 9 & 9 & 9 & 9 \\
\hline $\begin{array}{l}\text { (2) Maximum } \\
\text { weevil injury in } \\
\text { butt } 16 \mathrm{ft} \text { section } \\
\text { (number) }\end{array}$ & None & None & 2 injuries & No limit \\
\hline $\begin{array}{l}\text { (3) Minimum face } \\
\text { requirements on } \\
\text { butt } 16 \mathrm{ft} \text { section }\end{array}$ & $\begin{array}{l}\text { Two full length or } \\
\text { four } 50 \% \text { length } \\
\text { good faces }{ }^{1} \text { ( In } \\
\text { addition, knots on } \\
\text { balance of faces } \\
\text { shall not exceed } \\
\text { size limitations for } \\
\text { grade } 2 \text { sections) }\end{array}$ & $\begin{array}{l}\text { NO GOOD FACES } \\
\text { REQUIRED. } \\
\text { Maximum diameter } \\
\text { of knots on three } \\
\text { best faces: } \\
\text { SOUND RED } \\
\text { KNOTS not to } \\
\text { exceed } 1 / 6 \text { of } \\
\text { scaling dia. or } 3 \\
\text { inch maximum } 2 \\
\text { DEAD OR BLACK } \\
\text { KNOTS, including } \\
\text { overgrown knots, } \\
\text { not to exceed } 1 / 12 \\
\text { scaling dia. and } 1- \\
1 / 2 \text { inch max. }\end{array}$ & $\begin{array}{l}\text { NO GOOD FACES } \\
\text { REQUIRED. } \\
\text { Maximum diameter } \\
\text { of knots on three } \\
\text { best faces: } \\
\text { SOUND RED } \\
\text { KNOTS not to } \\
\text { exceed } 1 / 3 \text { of } \\
\text { scaling diameter or } \\
5 \text { inch maximum } 2 \\
\text { DEAD OR BLACK } \\
\text { KNOTS, including } \\
\text { overgrown knots, } \\
\text { not to exceed } 1 / 6 \\
\text { scaling dia. and } 2- \\
1 / 2 \text { inch max. }\end{array}$ & $\begin{array}{l}\text { Includes all trees } \\
\text { not qualifying for } \\
\text { grade } 3 \text { or better } \\
\text { and judged to have } \\
\text { at least } 1 / 3 \text { of their } \\
\text { gross volume in } \\
\text { sound wood } \\
\text { suitable for } \\
\text { manufacture into } \\
\text { standard lumber }\end{array}$ \\
\hline $\begin{array}{l}\text { (4) Maximum } \\
\text { sweep or crook in } \\
\text { butt } 16 \mathrm{ft} \text { section } \\
\text { (percent) }\end{array}$ & 20 & 30 & 40 & No limit \\
\hline $\begin{array}{l}\text { (5) Maximum total } \\
\text { scaling deduction } \\
\text { in butt } 16 \mathrm{ft} \text {. } \\
\text { section (percent) }\end{array}$ & 50 & 50 & 50 & No limit \\
\hline
\end{tabular}

After the tentative grade of the section is established from face examination, the section will be reduced one grade whenever the following defects are evident:

CONKS, PUNK KNOTS, AND PINE BORER DAMAGE ON THE SURFACE OF THE SECTION ${ }^{3}$ Degrade one grade if present on one face. Degrade two grades if present on two faces. Degrade three grades if present on three or four faces.

(7) If the final grade of the grading section is 1,2 , or 3 , examine the tree for weevil injuries in the merchantable stem above $16 \mathrm{ft}$. If the total apparent weevil injuries exceed three, degrade the tree one grade below the section grade ${ }^{3}$. Otherwise the tree grade equals the final section grade.

Trees under 16 inches DBH require four full length good faces.

${ }^{2}$ Scaling diameter is estimated at the top of the 16 -foot grading section.

${ }^{3}$ No tree will be designated below Grade 4 unless net tree scale is less than one-third of gross tree scale. 


\section{Tree-Grade Classification (continued)}

\section{SOUTHERN PINE TREE GRADES}

Grade 1 - trees with 3 or 4 clear faces on the 16-foot grading section.

Grade 2 - trees with 1 or 2 clear faces on the 16-foot grading section.

Grade 3 - trees with no clear faces on the 16 -foot grading section.

After the tentative grade is established, the tree will be reduced one grade for each of the following:

(1) Sweep. Degrade any tentative Grade 1 or 2 tree one grade if sweep in the lower 12 feet of the grading section amounts to 3 or more inches and equals or exceeds one-fourth the diameter at breast height.

(2) Heart rot. Degrade any tentative Grade 1 or 2 tree one grade if conks, punk knots, or other evidence of advanced heart rot is found anywhere on the tree stem.

NOTE: No tree can be degraded below Grade 3, provided the total scaling deductions for sweep and/or rot do not exceed two-thirds the gross scale of the tree. Trees with total scaling deductions in excess of twothirds are classified as cull.

A face is one-fourth the circumference of the 16-foot grading section and extends the full length of the grading section. Clear faces are those free from knots measuring more than $1 / 2$ inch in diameter, overgrown knots of any size, and holes more than $1 / 4$ inch in diameter. Faces may be rotated, if necessary, to obtain the maximum number of clear faces on the grading section.

One-log trees are graded by using the Southern Pine Log Grades. This is recommended because the entire merchantable volume of the tree is contained in the graded section. The log grading system gives a more accurate prediction of the lumber grade-yields for such trees than would the tree grading system.

\section{SPRUCE, FIR, CEDAR, TAMARACK, AND HEMLOCK LOGS}

\begin{tabular}{|c|c|c|c|c|}
\hline \multicolumn{5}{|c|}{ Minimum Merchantability Specifications for Grade One Logs } \\
\hline D.I.B. ${ }^{1}$ & LENGTH $^{2}$ & $\begin{array}{c}\text { TOTAL } \\
\text { DEDUCTION }\end{array}$ & $\begin{array}{c}\text { SWEEP } \\
\text { PERMITTED }\end{array}$ & OTHER REQUIREMENTS \\
\hline $6^{n}-12^{n}$ & $\begin{array}{c}12^{\prime}-16^{\prime} \text { in } 2 \\
\text { foot multiples }\end{array}$ & $50 \%$ & $25 \%$ & $\begin{array}{l}\text { Sound knots not over } 2^{n} \text { in diameter } \\
\text { permitted. Shake permitted up to } 20 \\
\% \text { of gross scale if not combined with } \\
\text { other serious defect. }\end{array}$ \\
\hline $13^{n}+$ & $\begin{array}{c}12^{\prime}-16^{\prime} \text { in } 2 \\
\text { foot multiples }\end{array}$ & $50 \%$ & $25 \%$ & $\begin{array}{l}\text { Sound knots not over } 3^{n} \text { in diameter } \\
\text { permitted. Shake permitted up to } 20 \\
\% \text { of gross scale if not combined with } \\
\text { other serious defect. }\end{array}$ \\
\hline
\end{tabular}

\footnotetext{
1 ...at small end of $\mathrm{log}$.

2 ...without trim.
}

TREE GRADE 5 (ALL SPECIES)

Any tree which does not make tree grade 1,2 , or 3 (or 4 ) but is still a merchantable tree. 


\section{Field Plot Data Quality Standards}

A quality assurance (QA) program is performed to ensure that a final product will meet the desired level of accuracy and precision. Quality control (QC) procedures are specific actions within the quality assurance program that are designed to maintain data quality within an acceptable range. There are three basic aspects of any QA program: error prevention, assessment and appraisal, and correction. Error prevention is achieved by developing standardized methods, establishing measurement quality objectives and data quality standards, and applying calibration techniques and training. Assessment and appraisal is accomplished by performing audits, debriefings and field personnel feedback, data validation and verification, and a remeasurement program for QC data collection. The purpose of correction, the last aspect of the quality assurance program, is to use all of the information from the prevention and assessment and appraisal components to make improvements, where needed, in the measurement system.

Our periodic resource inventories are designed to satisfy specified precision objectives. Much of our resource information comes from a statistically sound but very small sample of actual ground conditions that were selected to satisfy the precision objectives. While there is no guarantee that the data are completely errorfree, it is obvious that field errors must be kept to a minimum. Establishing and adhering to a quality assurance (QA) program can accomplish this objective. By setting standards and monitoring fieldwork, we can detect and correct, prevent, or eliminate the repetition of most errors.

After the initial training period, periodic inspections are made of every crew's fieldwork by field supervisors. The number of errors detected will partially determine frequency of inspections. All instances of error are analyzed and discussed with the crew concerned. Supervisors monitor progress and goals, and minimum acceptable performance levels are adjusted as conditions warrant. In addition, a percentage of all plots are subjected to a second measurement as part of the quality control program.

Tolerance levels are set depending on the type of data item. When an item is obtained by measurements that can be repeated with uniform results by several individuals, close tolerance limits that define acceptable data are set. Some items require subjective evaluation; the breadth of the tolerance limits depends on the degree of subjectivity. When an item requires a mutually exclusive answer, crews are expected to complete the item as best they can, based on their training, instructions received, and evidence on the plot, with zero tolerance for error.

\section{Quality Control Program}

The following procedures were followed to obtain the QC tree data results.

\section{Sample Size}

* Four percent random sample of all plots in state is selected.

\section{Data Collection}

* Crew 1 visits a plot.

* The plot is identified as QC by field supervisor.

* Crew 2 visits the same plot.

\section{Compilation}

* Trees from both data sets (Crew 1 and 2) are extracted from forested subplots.

* Trees are matched between sets based on the following criteria:

1) Tree numbers for all remeasure trees.

2) Distance, azimuth, and species for all new or ingrowth trees.

\section{Comparison}

* Tolerance limits from state field instructions are used to compare the tree data between Crew 1 and Crew 2.

* Four tree data item classes are grouped prior to applying tolerance.

1) Six condition classes are reduced to three: live, dead, or snag. 
2) Six tree grades are reduced to four: merchantable, tie \& timber, cull, and dead.
3) Six tree classes are reduced to five: preferred and acceptable, rough, rotten, dead, and snag.

4) Three merchantability classes are reduced to two: sound and unsound.

Results

Tree data items are presented as:

* Percentage of data within tolerance limits, and

* Number of times data exceeded tolerance limits.

* Values are either within tolerance $(1 x)$ or exceed tolerance $(2 x, 3 x$, or $4 x)$.

Vermont QA Tree Data Results from 121

Subplots"

\begin{tabular}{|c|c|c|c|c|c|c|c|c|c|c|}
\hline \multirow[b]{2}{*}{ Tree data item } & & \multicolumn{4}{|c|}{$\begin{array}{c}\text { Percentage of data within } \\
\text { tolerance }\end{array}$} & \multicolumn{4}{|c|}{$\begin{array}{l}\text { Number of times data } \\
\text { exceeded tolerance }\end{array}$} & \multirow{2}{*}{$\begin{array}{l}\text { Record } \\
\mathrm{s}\end{array}$} \\
\hline & & Q1x & $02 x$ & @ $3 x$ & @ 4x & $@ 1 x$ & Q2x & Q $3 x$ & Q $4 x$ & \\
\hline Species & - No tolerance & $96 \%$ & & & & 75 & & & & $\uparrow, 958$ \\
\hline Trees (missed) & - No tolerance & $98 \%$ & & & & (38) & & & & 1,958 \\
\hline Horizontal distance & -.2 feet $(+$ or -$)$ & $74 \%$ & $89 \%$ & $93 \%$ & & 505 & 225 & 133 & & 1,958 \\
\hline Azimuth & -2 degrees (+ or - ) & $74 \%$ & $91 \%$ & $95 \%$ & & 514 & 184 & 104 & & 1,958 \\
\hline Tree history & - No tolerance & $94 \%$ & & & & 66 & & & & 1,076 \\
\hline Diameter & -.1 inch (+ or -$)$ & $88 \%$ & $93 \%$ & $95 \%$ & & 184 & 106 & 83 & & 1,545 \\
\hline Ecotype & - No tolerance & $95 \%$ & & & & 64 & & & & 1,352 \\
\hline Condition & - No tolerance & $87 \%$ & & & & 191 & & & & 1,491 \\
\hline Tree grade & - No tolerance & $77 \%$ & & & & 69 & & & & 304 \\
\hline Saw length & -4 feet $(+$ or -$)$ & $53 \%$ & $73 \%$ & $84 \%$ & $92 \%$ & 142 & 82 & 48 & 24 & 304 \\
\hline Bole length & -4 feet $(+$ or -$)$ & $52 \%$ & $76 \%$ & $89 \%$ & $95 \%$ & 530 & 266 & 119 & 60 & 1,106 \\
\hline Total length & -10 feet $(+$ or -$)$ & $82 \%$ & $96 \%$ & $98 \%$ & & 218 & 49 & 25 & & 1,237 \\
\hline Board foot cull & $-10 \%(+$ or -$)$ & $77 \%$ & $90 \%$ & $93 \%$ & $94 \%$ & 71 & 29 & 20 & 17 & 304 \\
\hline Board foot soundness & -1 class (+ or - ) & $91 \%$ & $92 \%$ & $93 \%$ & $93 \%$ & 27 & 24 & 22 & 20 & 304 \\
\hline Cubic foot cull & $-10 \%(+$ or -$)$ & $81 \%$ & $93 \%$ & $97 \%$ & $99 \%$ & 206 & 72 & 30 & 13 & 1,106 \\
\hline Cubic foot soundness & -1 class (+ or - ) & $89 \%$ & $90 \%$ & $91 \%$ & $92 \%$ & 122 & 112 & 102 & 94 & 1,106 \\
\hline Crown ratio & -1 class (+ or - ) & $89 \%$ & $97 \%$ & & & 125 & 34 & & & 1,106 \\
\hline Crown class & - No tolerance & $76 \%$ & & & & 266 & & & & 1,106 \\
\hline General damage & - Variable tolerance & $100 \%$ & & & & 0 & & & & 1,106 \\
\hline Special damage & - Variable tolerance & $90 \%$ & & & & 223 & & & & 2,212 \\
\hline Tree class & - No tolerance & $89 \%$ & & & & 163 & & & & 1,491 \\
\hline Merchantability class & - No tolerance & $91 \%$ & & & & 125 & & & & 1,339 \\
\hline
\end{tabular}




\section{Metric Equivalents}

1 acre $=4,046.86$ square meters

1 acre $=0.404686$ hectares

1,000 acres $=404.686$ hectares

$1,000,000$ acres $=404,686$ hectares

1 board foot $=0.00348$ cubic meters

1 board foot $=3,480$ cubic centimeters

1,000 board feet $=3.48$ cubic meters

$1,000,000$ board feet $=3,480$ cubic meters

1 cubic foot $=0.028317$ cubic meters

1,000 cubic feet $=28.317$ cubic meters

$1,000,000$ cubic feet $=28,317$ cubic meters

1 cord (wood, bark, and air space) $=3.6246$ cubic meters

1 cord (solid wood, pulpwood) $=2.4069$ cubic meters

1 cord (solid wood, other than pulpwood) $=2.2654$ cubic meters

1,000 cords (pulpwood) $=2,406.9$ cubic meters

1,000 cords (other products) $=2,265.4$ cubic meters

1 inch $=2.54$ centimeters or 0.0254 meters

1 foot $=30.48$ centimeters or 0.3048 meters

1 mile $=1.609$ kilometers

1 square foot $=929.03$ square centimeters

1 square foot $=0.0929$ square meters

1 square foot per acre basal area $=0.229568$ square meters per hectare

1 cubic foot per acre $=0.0699$ cubic meters per hectare

1 ton $=907.1848$ kilograms

1,000 tons $=907.1848$ metric tons

Breast height $=1.4$ meters above ground level

Although 1,000 board feet are theoretically equivalent to 2.36 cubic meters, this is true only when a board foot is actually a piece of wood with a volume $1 / 12$ of a cubic foot. The International 1/4-inch log rule is used by the USDA Forest Service in the East to estimate the product potential in board feet. The reliability of the estimate obtained by conversion will vary with the size of the log measure. The conversion given here, 3.48 cubic meters, is based on the cubic volume of a log 16 feet long and 15 inches in diameter inside bark (d.i.b.) at the small end. This conversion could be used for average comparisons when accuracy of 10 percent is acceptable. Because the board foot unit is not a true measure of wood volume and because products other than dimension lumber are becoming important, this unit may eventually be phased out and replaced by the cubic meter. 


\section{INDEX TO TABLES}

The following tables are divided into four major sections: (1) State, (2) Northern Unit,

Southern Unit and (4) County tables.

\section{State Tables}

\section{Area}

1. Total land area by land use class, Vermont, 1997.

2. Area of timberland by forest type, foresttype group, and stand-size class, Vermont, 1983.

3. Area of timberland by forest type, foresttype group, and stand-size class, Vermont, 1997.

4. Area of timberland by forest-type group and ownership class, Vermont, 1997.

5. Area of timberland by stand-size class and ownership class, Vermont, 1997.

6. Area of timberland by forest-type group and cubic-foot stand-volume class of all live trees, Vermont, 1997.

7. Area of timberland by forest-type group and cubic-foot stand-volume class of growing stock trees, Vermont, 1997.

8. Area of timberland by forest-type group and board-foot stand-volume class, Vermont, 1997.

9. Area of timberland by forest-type group and basal-area class, Vermont, 1997.

10. Area of timberland by forest-type group and stocking class of all live trees, Vermont, 1983.

11. Area of timberland by forest-type group and stocking class of all live trees, Vermont, 1997.
12. Area of timberland by forest-type group and stocking class of growing-stock trees, Vermont, 1983.

13. Area of timberland by forest-type group and stocking class of growing-stock trees, Vermont, 1997.

\section{Number of Trees}

14. Number of trees (5.0+ inches d.b.h.) on timberland by species and tree class, Vermont, 1997.

15. Number of standing dead trees (5.0+ inches d.b.h.) on timberland by species, condition class, and diameter class, Vermont, 1997.

16. Number of seedlings, saplings, and shrubs on timberland by species and stand-size class, Vermont, 1997.

17. Number of live trees (1.0+ inches d.b.h.) on timberland by species and diameter class, Vermont, 1997.

18. Number of growing-stock trees $(5.0+$ inches d.b.h.) on timberland by species and diameter class, Vermont, 1983.

19. Number of growing-stock trees (5.0+ inches d.b.h.) on timberland by species and diameter class, Vermont, 1997.

\section{Volume}

20. Net volume of all trees on timberland by species and tree class, Vermont, 1997.

21. Net volume of all live trees on timberland by species and diameter class, Vermont, 1983.

22. Net volume of live trees on timberland by species and diameter class, Vermont, 1997.

23. Net volume of growing-stock trees on timberland by species and diameter class, Vermont, 1983.

24. Net volume of growing-stock trees on timberland by species and diameter class, Vermont, 1997. 
25. Net volume of growing-stock trees on timberland by species and stand-size class, Vermont, 1983.

26. Net volume of growing-stock trees on timberland by species and stand-size class, Vermont, 1997.

27. Net volume of growing-stock trees on timberland by forest type and stand-size class, Vermont, 1997.

28. Net volume of growing-stock trees on timberland by species and forest-type group, Vermont, 1983.

29. Net volume of growing-stock trees on timberland by species and forest-type group, Vermont, 1997.

30. Net volume of growing-stock in the sawlog portion of sautimber trees on timberland by species and diameter class, Vermont, 1997.

31. Net volume of sawtimber trees on timberland by species and diameter class, Vermont, 1983.

32. Net volume of sawtimber trees on timberland by species and diameter class, Vermont, 1997.

33. Net volume of sawtimber trees on timberland by species, size class, and tree grade, Vermont, 1997.

\section{Change}

34. Average annual net change of growingstock volume on timberland by species and component of change, Vermont, 1997.

35. Average annual net change of sawtimber volume on timberland by species and component of change, Vermont, 1997.

\section{Northern Unit Tables}

36. Area of timberland by forest type, foresttype group, and stand-size class, Northern Unit, Vermont, 1983.
37. Area of timberland by forest type, foresttype group, and stand-size class, Northern Unit, Vermont, 1997.

38. Number of live trees (1.0+ inches d.b.h.) on timberland by species and diameter class, Northern Unit, Vermont, 1997.

39. Number of growing-stock trees (5.0+ inches d.b.h.) on timberland by species and diameter class, Northern Unit, Vermont, 1983.

40. Number of growing-stock trees (5.0+ inches d.b.h.) on timberland by species and diameter class, Northern Unit, Vermont, 1997.

41. Net volume of all trees on timberland by species and tree class, Northern Unit, Vermont, 1997.

42. Net volume of all live trees on timberland by species and diameter class, Northern Unit, Vermont, 1983.

43. Net volume of live trees $(5.0+$ inches d.b.h.) on timberland by species and diameter class, Northern Unit, Vermont, 1997.

44. Net volume of growing-stock trees on timberland by species and diameter class, Northern Unit, Vermont, 1983.

45. Net volume of growing-stock trees on timberland by species and diameter class, Northern Unit, Vermont, 1997.

46. Net volume of growing-stock trees on timberland by species and stand-size class, Northern Unit, Vermont, 1983.

47. Net volume of growing-stock trees on timberland by species and stand-size class, Northern Unit, Vermont, 1997.

48. Net volume of growing-stock trees on timberland by forest type and stand-size class, Northern Unit, Vermont, 1997.

49. Net volume of growing-stock trees on timberland by species and forest-type group, Northern Unit, Vermont, 1983. 
50. Net volume of growing-stock trees on timberland by species and forest-type group, Northern Unit, Vermont, 1997.

51. Net volume of growing-stock in the sawlog portion of sawtimber trees on timberland by species and diameter class, Northern Unit, Vermont, 1997.

52. Net volume of sawtimber trees on timberland by species and diameter class, Northern Unit, Vermont, 1983.

53. Net volume of sawtimber trees on timberland by species and diameter class, Northern Unit, Vermont, 1997.

54. Average annual net change of growingstock volume on timberland by species and component of change, Northern Unit, Vermont, 1997.

55. Average annual net change of sawtimber volume on timberland by species and component of change, Northern Unit, Vermont, 1997.

\section{Southern Unit Tables}

56. Area of timberland by forest type, foresttype group, and stand-size class, Southern Unit, Vermont, 1983.

57. Area of timberland by forest type, foresttype group, and stand-size class, Southern Unit, Vermont, 1997.

58. Number of live trees (1.0+ inches d.b.h.) on timberland by species and diameter class, Southern Unit, Vermont, 1997.

59. Number of growing-stock trees (5.0+ inches d.b.h.) on timberland by species and diameter class, Southern Unit, Vermont, 1983.

60. Number of growing-stock trees (5.0+ inches d.b.h.) on timberland by species and diameter class, Southern Unit, Vermont, 1997.

61. Net volume of all trees on timberland by species and tree class, Southern Unit, Vermont, 1997.
62. Net volume of all live trees on timberland by species and diameter class, Southern Unit, Vermont, 1983.

63. Net volume of live trees $(5.0+$ inches d.b.h.) on timberland by species and diameter class, Southern Unit, Vermont, 1997.

64. Net volume of growing-stock trees on timberland by species and diameter class, Southern Unit, Vermont, 1983.

65. Net volume of growing-stock trees on timberland by species and diameter class, Southern Unit, Vermont, 1997.

66. Net volume of growing-stock trees on timberland by species and stand-size class, Southern Unit, Vermont, 1983.

67. Net volume of growing-stock trees on timberland by species and stand-size class, Southern Unit, Vermont, 1997

68. Net volume of growing-stock trees on timberland by forest type and stand-size class, Southern Unit, Vermont, 1997.

69. Net volume of growing-stock trees on timberland by species and forest-type group, Southern Unit, Vermont, 1983.

70. Net volume of growing-stock trees on timberland by species and forest-type group, Southern Unit, Vermont, 1997.

71. Net volume of growing-stock in the sawlog portion of sawtimber trees on timberland by species and diameter class, Southem Unit, Vermont, 1997.

72. Net volume of sawtimber trees on timberland by species and diameter class, Southern Unit, Vermont, 1983.

73. Net volume of sawtimber trees on timberland by species and diameter class, Southern Unit, Vermont, 1997.

74. Average annual net change of growingstock volume on timberland by species and component of change, Southern Unit, Vermont, 1997. 
75. Average annual net change of sawtimber volume on timberland by species and component of change, Southern Unit, Vermont, 1997.

\section{County Tables}

76. Net land area by county, and land class, Vermont, 1997.

77. Area of timberland by county and ownership class, Vermont, 1997.

78. Area of timberland by county and foresttype group, Vermont, 1997.

79. Area of timberland by county and standsize class, Vermont, 1997.

80. Area of timberland by county and stocking class of growing-stock trees, Vermont, 1997.
81. Net volume of growing-stock trees on timberland by county and forest-type group, Vermont, 1997.

82. Net volume of growing-stock trees on timberland by county and stand-size class, Vermont, 1997.

83. Net volume of sawtimber trees on timberland by county and forest-type group, Vermont, 1997.

84. Net volume of sawtimber trees on timberland by county and stand-size class, Vermont, 1997.

85. Biomass of all trees and shrubs on timberland, by county and class of material, Vermont, 1997.

86. Biomass of all timber on timberland, by county and class of material, Vermont, 1997. 



\section{STATE TABLES}

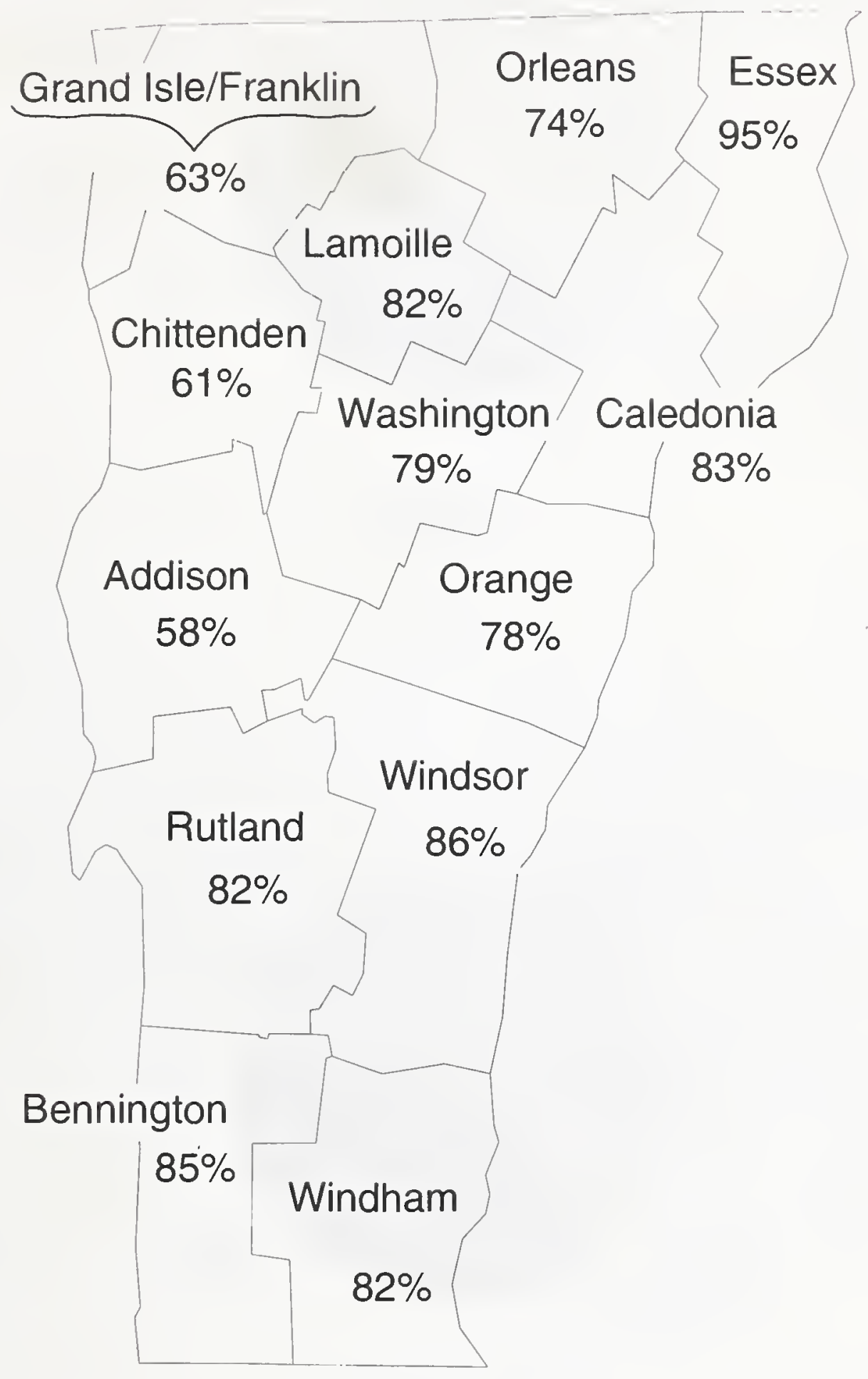

$\frac{\Phi}{\frac{\pi}{0}}$

Percentage of land in forest by county, 1997

(State average $=78.2$ percent $)$ 
Timberland area by stand-size class

Vermont, 1983 and 1997

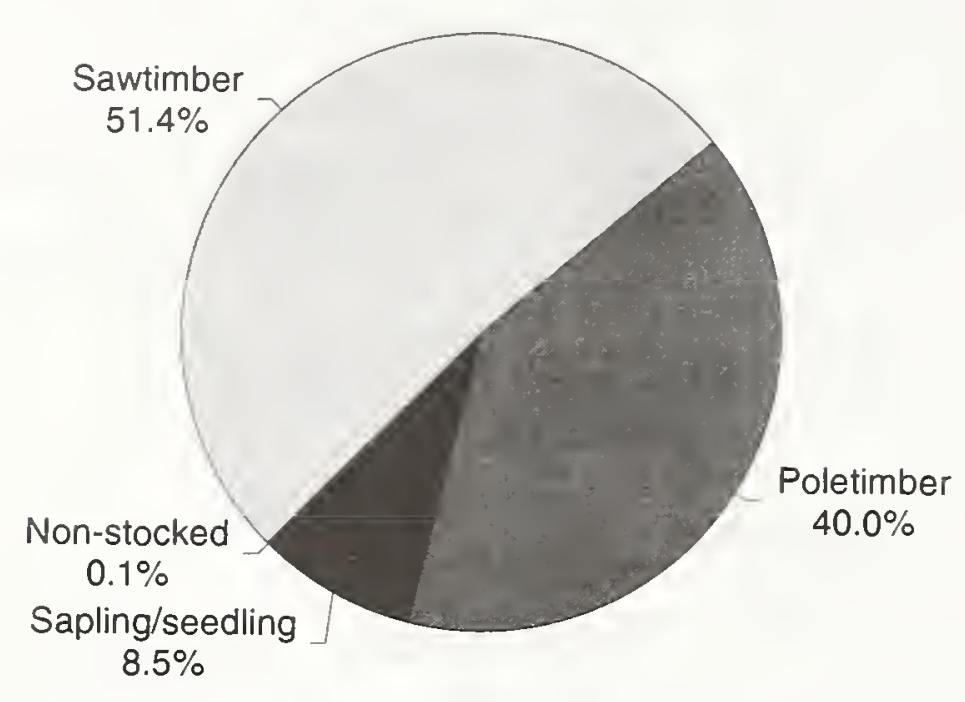

1983

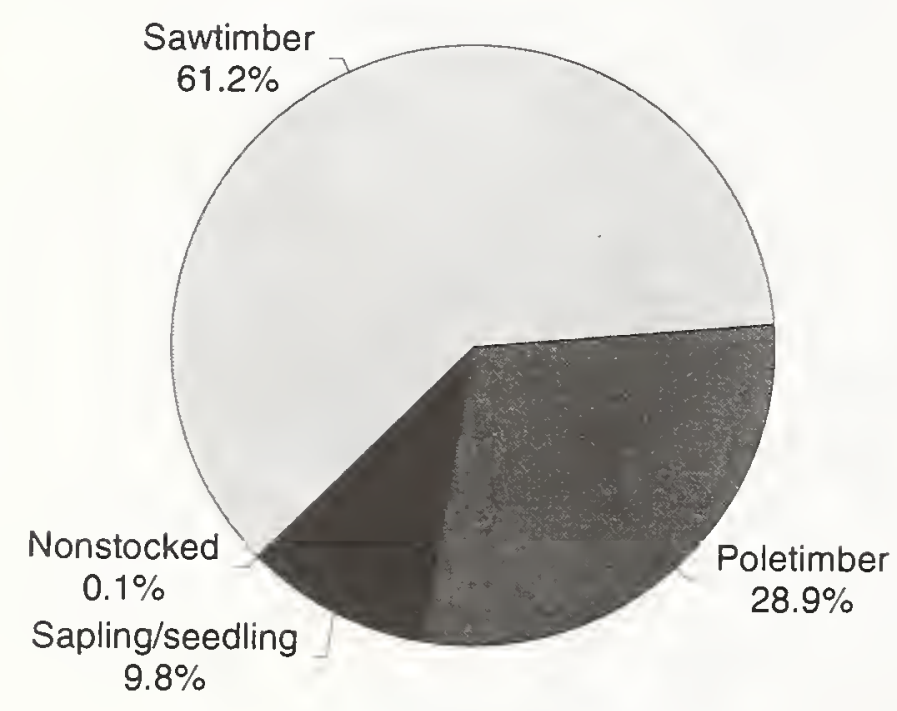

1997 
Table 1.--Land area by Land class, Vermont, 1983 and $1997^{\mathrm{a}}$

(In thousands of acres)

\begin{tabular}{|c|c|c|c|c|}
\hline \multirow{2}{*}{ Land class } & \multicolumn{4}{|c|}{ Area } \\
\hline & 1983 & Percent & 1997 & Percent \\
\hline Timber land & $4,412.9$ & 76 & 4.482 .5 & 75 \\
\hline \multicolumn{5}{|l|}{ Noncommercial forest land: } \\
\hline Reserved productive & 89.1 & 2 & 114.1 & 2 \\
\hline Urban forest land & 0.0 & $<1$ & 3.8 & $<1$ \\
\hline Other forest land & 33.9 & $<1$ & 17.7 & $<1$ \\
\hline Christmas tree plantations & 0.0 & $<1$ & 10.7 & $<1$ \\
\hline Total noncommercial ... & 123.0 & 2 & 146.3 & 2 \\
\hline Total forest land & $4,535.9$ & 77 & $4,628.9$ & 78 \\
\hline \multicolumn{5}{|l|}{ Nonforest land: } \\
\hline Cropl and & 482.1 & 8 & 398.6 & 7 \\
\hline Pasture & 357.4 & 6 & 273.4 & 5 \\
\hline other & 544.2 & 9 & 618.9 & 10 \\
\hline Total nonforest land & $1,384.7$ & 23 & $1,290.8$ & 22 \\
\hline Total land area & $5,919.6$ & 100 & $5,919.6$ & 100 \\
\hline $\begin{array}{l}\text { An this and other tables, a } \\
\text { negligible or the condition } \\
\text { A dash indicates that the c } \\
\text { borest Service definitions. } \\
c \text { Rows and columns in all tab } \\
\text { "Other forest land" formerl } \\
\text { Source: } 1990 \text { United States }\end{array}$ & $\begin{array}{l}\text { indicates } \\
\text { hot encoun } \\
\text { on is not } \\
\text { not sum } \\
\text { ant unpr }\end{array}$ & $\begin{array}{l}t \text { the dat } \\
d \text { in the } \\
\text { sible uno } \\
\text { to roune } \\
\text { tive fore } \\
\text { rce, Bure }\end{array}$ & $\begin{array}{l}\text { e } \\
\text { le. } \\
\text { urrent }\end{array}$ & \\
\hline
\end{tabular}


Table 2.--Area of timberland by forest type, forest-type group, and stand-size class, Vermont, 1983

(In thousands of acres)

\begin{tabular}{|c|c|c|c|c|c|c|}
\hline \multirow{2}{*}{ Forest type } & \multicolumn{4}{|c|}{ Stand-size class } & \multirow{2}{*}{$\begin{array}{c}\text { All } \\
\text { classes }\end{array}$} & \multirow{2}{*}{ SE } \\
\hline & $\begin{array}{l}\text { Saw- } \\
\text { timber }\end{array}$ & $\begin{array}{l}\text { Pole- } \\
\text { timber }\end{array}$ & $\begin{array}{l}\text { Sapl ing and } \\
\text { seedl ing }\end{array}$ & $\begin{array}{l}\text { Non- } \\
\text { stocked }\end{array}$ & & \\
\hline Red pine & 7.5 & .0 & .0 & .0 & 7.5 & 100.0 \\
\hline White pine & 115.7 & 55.8 & 7.0 & .0 & 178.6 & 19.6 \\
\hline White pine/hemlock & 56.5 & 6.7 & .0 & .0 & 63.2 & 33.0 \\
\hline Hemlock & 182.4 & 43.5 & .0 & .0 & 225.9 & 17.5 \\
\hline White/red pine group & 362.2 & 106.0 & 7.0 & .0 & 475.2 & 11.4 \\
\hline Balsam fir & 52.8 & 79.7 & 29.7 & .0 & 162.2 & 19.7 \\
\hline Red spruce & 43.1 & 43.8 & .0 & .0 & 86.9 & 28.8 \\
\hline Red spruce/balsam fir & 73.9 & 66.5 & 14.9 & .0 & 155.2 & 21.2 \\
\hline White spruce & 7.4 & 15.4 & 12.7 & .0 & 35.5 & 44.9 \\
\hline Northern white-cedar & 37.4 & 14.4 & .0 & .0 & 51.8 & 37.4 \\
\hline Spruce/fir group & 214.6 & 219.8 & 57.3 & .0 & 491.6 & 10.6 \\
\hline Wh. pine/no.red oak/wh. ash & 14.0 & .0 & .0 & .0 & 14.0 & 70.7 \\
\hline Oak/pine group & 14.0 & .0 & .0 & .0 & 14.0 & 70.7 \\
\hline White oak/red oak/hickory & .0 & 20.5 & .0 & .0 & 20.5 & 57.0 \\
\hline White oak & .0 & 6.7 & .0 & .0 & 6.7 & 100.0 \\
\hline Northern red oak & 29.5 & 14.2 & .0 & .0 & 43.7 & 40.8 \\
\hline Hawthorn/reverting field & .0 & 2.8 & 7.1 & .0 & 9.9 & 77.2 \\
\hline Red maple/central hardwood & .0 & 6.4 & .0 & .0 & 6.4 & 100.0 \\
\hline Mixed central hardwoods & 28.5 & 29.4 & 18.8 & .0 & 76.7 & 30.2 \\
\hline Oak/hickory group & 58.0 & 80.0 & 25.9 & .0 & 163.9 & 20.1 \\
\hline Black ash/Amer. elm/red maple & 22.6 & 47.5 & 21.8 & .0 & 91.9 & 27.5 \\
\hline Red maple(upl and) & .0 & 7.1 & 6.4 & .0 & 13.5 & 70.8 \\
\hline Cottonwood & .0 & 7.0 & .0 & .0 & 7.0 & 100.0 \\
\hline Willow & .0 & .0 & 5.0 & .0 & 5.0 & 100.0 \\
\hline American elm/green ash & 7.6 & 7.4 & .0 & .0 & 15.0 & 70.7 \\
\hline Elm/ash/red maple group & 30.2 & 69.1 & 33.2 & .0 & 132.4 & 22.4 \\
\hline Sugar maple/beech/yellow birch & $1,324.1$ & 741.3 & 74.4 & .0 & $2,139.9$ & $\begin{aligned} 4.1 \\
72 \\
7\end{aligned}$ \\
\hline Black Cherry & & 4.9 & 7.7 & .0 & 12.6 & 72.5 \\
\hline Red maple/northern hardwoods & 127.4 & 171.1 & 22.0 & .0 & 320.5 & 14.4 \\
\hline Pin cherry/reverting field & .0 & & 48.6 & 5.6 & 54.2 & 32.7 \\
\hline Mixed nor thern hardwoods & 78.4 & 146.3 & 82.0 & .0 & 306.7 & 14.2 \\
\hline Northern hardwoods group & $1,530.0$ & $1,063.5$ & 234.7 & 5.6 & $2,833.8$ & 3.0 \\
\hline Aspen & 22.0 & 44.4 & 19.2 & .0 & 85.5 & 28.6 \\
\hline Paper birch & 35.2 & 166.9 & .0 & .0 & 202.0 & 18.2 \\
\hline Gray birch & .0 & 14.3 & .0 & .0 & 14.3 & 70.8 \\
\hline Aspen/birch group & 57.1 & 225.6 & 19.2 & .0 & 301.9 & 14.8 \\
\hline All forest types & $2,266.1$ & $1,764.0$ & 377.3 & 5.6 & $4,412.9$ & .7 \\
\hline SE & 3.8 & 4.9 & 10.7 & 100.0 & .7 & \\
\hline
\end{tabular}


Table 3.--Area of timberland by forest type, forest-type group, and stand-size class, Vermont, 1997

(In thousands of acres)

\begin{tabular}{|c|c|c|c|c|c|c|}
\hline \multirow{2}{*}{ Forest type } & \multicolumn{4}{|c|}{ Stand-size class } & \multirow{2}{*}{$\begin{array}{c}\text { All } \\
\text { classes }\end{array}$} & \multirow{2}{*}{ SE } \\
\hline & $\begin{array}{l}\text { Saw- } \\
\text { timber }\end{array}$ & $\begin{array}{l}\text { Pole- } \\
\text { timber }\end{array}$ & $\begin{array}{l}\text { Sapling and } \\
\text { seedling }\end{array}$ & $\begin{array}{c}\text { Non- } \\
\text { stocked }\end{array}$ & & \\
\hline $\begin{array}{l}\text { Red pine } \\
\text { White pine } \\
\text { White pine/hemlock } \\
\text { Hemlock }\end{array}$ & $\begin{array}{r}3.3 \\
133.9 \\
80.0 \\
227.2\end{array}$ & $\begin{array}{r}.1 \\
25.2 \\
8.1 \\
2.2\end{array}$ & $\begin{array}{r}.0 \\
7.6 \\
3.5 \\
.0\end{array}$ & $\begin{array}{l}.0 \\
.0 \\
.5 \\
.0\end{array}$ & $\begin{array}{r}3.4 \\
166.7 \\
92.2 \\
229.4\end{array}$ & $\begin{array}{l}97.3 \\
17.5 \\
24.1 \\
15.1\end{array}$ \\
\hline White/red pine group & 444.4 & 35.6 & 11.1 & .5 & 491.7 & 9.7 \\
\hline $\begin{array}{l}\text { Balsam fir } \\
\text { Red spruce } \\
\text { Red spruce/balsam fir } \\
\text { White spruce } \\
\text { Black spruce } \\
\text { Norway spruce } \\
\text { Northern white-cedar } \\
\text { Tamarack }\end{array}$ & $\begin{array}{r}52.8 \\
36.7 \\
39.7 \\
20.1 \\
.0 \\
1.5 \\
25.3 \\
6.4\end{array}$ & $\begin{array}{r}119.0 \\
7.9 \\
42.5 \\
6.5 \\
.0 \\
.0 \\
12.6 \\
.0\end{array}$ & $\begin{array}{r}58.6 \\
.0 \\
25.6 \\
.0 \\
4.8 \\
.0 \\
.0 \\
.0\end{array}$ & $\begin{array}{l}.0 \\
.0 \\
.0 \\
.0 \\
.0 \\
.0 \\
.0 \\
.0\end{array}$ & $\begin{array}{r}230.4 \\
44.6 \\
107.8 \\
26.6 \\
4.8 \\
1.5 \\
37.9 \\
6.4\end{array}$ & $\begin{array}{r}14.9 \\
35.1 \\
22.3 \\
47.5 \\
100.0 \\
100.0 \\
38.7 \\
100.0\end{array}$ \\
\hline Spruce/fir group & 182.5 & 188.5 & 89.0 & .0 & 460.0 & 9.8 \\
\hline Wh. pine/no.red oak/wh. ash & 17.5 & 17.2 & .0 & .0 & 34.7 & 41.0 \\
\hline Oak/pine group & 17.5 & 17.2 & .0 & .0 & 34.7 & 41.0 \\
\hline $\begin{array}{l}\text { Chestnut oak } \\
\text { White oak/red oak/hickory } \\
\text { Northern red oak } \\
\text { Hawthorn/reverting field } \\
\text { Mixed central hardwoods }\end{array}$ & $\begin{array}{r}7.5 \\
15.9 \\
29.3 \\
.0 \\
58.8\end{array}$ & $\begin{array}{r}.0 \\
12.6 \\
6.6 \\
.0 \\
31.2\end{array}$ & $\begin{array}{r}.0 \\
.0 \\
.0 \\
1.1 \\
.0\end{array}$ & $\begin{array}{l}.0 \\
.0 \\
.0 \\
.0 \\
.0\end{array}$ & $\begin{array}{r}7.5 \\
28.5 \\
35.9 \\
1.1 \\
90.0\end{array}$ & $\begin{array}{r}100.0 \\
50.4 \\
44.1 \\
100.0 \\
26.4\end{array}$ \\
\hline Oak/hickory group & 111.6 & 50.4 & 1.1 & .0 & 163.1 & 19.5 \\
\hline $\begin{array}{l}\text { Black ash/Amer. elm/red maple } \\
\text { Red maple(upland) } \\
\text { Willow } \\
\text { American elm/green ash }\end{array}$ & $\begin{array}{r}10.3 \\
.0 \\
.0 \\
.0\end{array}$ & $\begin{array}{r}12.5 \\
5.0 \\
.0 \\
4.3\end{array}$ & $\begin{array}{r}21.0 \\
.0 \\
7.1 \\
.0\end{array}$ & $\begin{array}{l}.0 \\
.0 \\
.0 \\
.0\end{array}$ & $\begin{array}{r}43.8 \\
5.0 \\
7.1 \\
4.3\end{array}$ & $\begin{array}{r}35.9 \\
100.0 \\
79.4 \\
100.0\end{array}$ \\
\hline Elm/ash/red maple group & 10.3 & 21.8 & 28.2 & .0 & 60.2 & 29.1 \\
\hline $\begin{array}{l}\text { Sugar maple/beech/yellow birch } \\
\text { Black Cherry } \\
\text { Red maple/northern hardwoods } \\
\text { Pin cherry/reverting field } \\
\text { Mixed northern hardwoods }\end{array}$ & $\begin{array}{r}1.473 .7 \\
.0 \\
222.6 \\
.0 \\
183.4\end{array}$ & $\begin{array}{r}503.8 \\
2.2 \\
215.7 \\
15.2 \\
148.9\end{array}$ & $\begin{array}{r}81.0 \\
.0 \\
34.7 \\
103.7 \\
32.6\end{array}$ & $\begin{array}{r}.0 \\
.0 \\
.0 \\
2.6 \\
.0\end{array}$ & $\begin{array}{r}2.058 .4 \\
2.2 \\
473.0 \\
121.5 \\
364.9\end{array}$ & $\begin{array}{r}4.0 \\
100.0 \\
10.9 \\
19.9 \\
12.5\end{array}$ \\
\hline Northern hardwoods group & $1,879.7$ & 885.8 & 252.0 & 2.6 & $3,020.1$ & 2.7 \\
\hline $\begin{array}{l}\text { Aspen } \\
\text { Paper birch } \\
\text { Gray birch }\end{array}$ & $\begin{array}{r}40.6 \\
55.2 \\
.0\end{array}$ & $\begin{array}{r}27.3 \\
66.7 \\
3.3\end{array}$ & $\begin{array}{r}44.6 \\
13.0 \\
1.8\end{array}$ & $\begin{array}{l}.0 \\
.0 \\
.0\end{array}$ & $\begin{array}{r}112.6 \\
135.0 \\
5.0\end{array}$ & $\begin{array}{l}22.4 \\
20.8 \\
57.1\end{array}$ \\
\hline Aspen/birch group & 95.9 & 97.3 & 59.4 & .0 & 252.6 & 14.8 \\
\hline A!l forest types & $2,741.9$ & 1.296 .6 & 440.8 & 3.2 & $4,482.5$ & 1.0 \\
\hline SE & 2.9 & 5.8 & 10.1 & 85.3 & 1.0 & \\
\hline
\end{tabular}


Table 4.--Area of timberland by forest-type group and ownership class, Vermont, 1997

(In thousands of acres)

\begin{tabular}{|c|c|c|c|c|c|c|}
\hline \multirow{2}{*}{$\begin{array}{c}\text { Forest-type } \\
\text { group }\end{array}$} & \multicolumn{4}{|c|}{ Ownership class } & \multirow{2}{*}{$\begin{array}{c}\text { All } \\
\text { classes }\end{array}$} & \multirow{2}{*}{ SE } \\
\hline & $\begin{array}{r}\text { National } \\
\text { Forest }\end{array}$ & $\begin{array}{l}\text { Other } \\
\text { publ ic }\end{array}$ & $\begin{array}{l}\text { Forest } \\
\text { industry }\end{array}$ & $\begin{array}{c}\text { Other } \\
\text { private }\end{array}$ & & \\
\hline White/red pine & 1.9 & 35.9 & .0 & 453.9 & 491.7 & 9.7 \\
\hline Spruce/fir & 9.1 & 24.9 & 43.9 & 382.2 & 460.0 & 9.8 \\
\hline Oak/pine & .0 & .0 & .0 & 34.7 & 34.7 & 41.0 \\
\hline Oak/hickory & .0 & 10.7 & .0 & 152.3 & 163.1 & 19.5 \\
\hline Elm/ash/red maple & .0 & 11.4 & .0 & 48.8 & 60.2 & 29.1 \\
\hline Northern hardwoods & 237.4 & 277.6 & 191.7 & $2,313.5$ & $3,020.1$ & 2.7 \\
\hline Aspen/birch & 6.3 & 17.6 & 17.1 & 211.7 & 252.6 & 14.8 \\
\hline Total, all groups & 254.6 & 378.1 & 252.6 & $3,597.2$ & $4,482.5$ & 1.0 \\
\hline SE & 9.5 & 12.3 & 14.9 & 2.0 & 1.0 & \\
\hline
\end{tabular}

Table 5. Area of timberland by stand-size class and ownership class, Vermont, 1997

(In thousands of acres)

\begin{tabular}{|c|c|c|c|c|c|c|}
\hline \multirow{2}{*}{ Stand-size class } & \multicolumn{4}{|c|}{ Ownership class } & \multirow{2}{*}{$\begin{array}{c}\text { All } \\
\text { classes }\end{array}$} & \multirow{2}{*}{ SE } \\
\hline & $\begin{array}{l}\text { National } \\
\text { Forest }\end{array}$ & $\begin{array}{l}\text { Other } \\
\text { publ ic }\end{array}$ & $\begin{array}{r}\text { Forest } \\
\text { industry }\end{array}$ & $\begin{array}{c}\text { Other } \\
\text { private }\end{array}$ & & \\
\hline Sawt imber & 185.6 & 261.1 & 104.2 & $2,191.1$ & $2,741.9$ & 2.9 \\
\hline Poletimber & 57.9 & 102.8 & 110.7 & $1,025.3$ & $1,296.6$ & 5.8 \\
\hline Sapling and seedling & 11.1 & 14.2 & 37.8 & 377.7 & 440.8 & 10.1 \\
\hline Nonstocked & .0 & .0 & .0 & 3.2 & 3.2 & 85.3 \\
\hline Total, all classes & 254.6 & 378.1 & 252.6 & $3,597.2$ & $4,482.5$ & 1.0 \\
\hline SE & 9.5 & 12.3 & 14.9 & 2.0 & 1.0 & \\
\hline
\end{tabular}


Table 6.--Area of timberland by forest-type group and cubic-foot stand-volume class of all live trees, Vermont, 1997

(In thousands of acres)

\begin{tabular}{|c|c|c|c|c|c|c|c|c|}
\hline \multirow{2}{*}{$\begin{array}{c}\text { Forest-type } \\
\text { group }\end{array}$} & \multicolumn{6}{|c|}{ Stand-volume class (cubic feet per acre) } & \multirow{2}{*}{$\begin{array}{c}\text { All } \\
\text { classes }\end{array}$} & \multirow{2}{*}{ SE } \\
\hline & $\begin{array}{l}0- \\
499\end{array}$ & $\begin{array}{l}500- \\
999\end{array}$ & $\begin{array}{l}1000- \\
1499\end{array}$ & $\begin{array}{l}1500- \\
1999\end{array}$ & $\begin{array}{l}2000- \\
2499\end{array}$ & $2500+$ & & \\
\hline White/red pine & 18.1 & 15.6 & 47.3 & 62.8 & 69.9 & 277.9 & 491.7 & 9.7 \\
\hline Spruce/fir & 56.5 & 58.2 & 68.1 & 59.4 & 64.7 & 153.2 & 460.0 & 9.8 \\
\hline Oak/pine & .0 & .0 & 4.8 & 11.4 & .0 & 18.5 & 34.7 & 41.0 \\
\hline Oak/hickory & .0 & .0 & 24.0 & 34.0 & 36.0 & 69.1 & 163.1 & 19.5 \\
\hline Elm/ash/red maple & 14.5 & 18.4 & 1.7 & 11.4 & 11.0 & 3.2 & 60.2 & 29.1 \\
\hline Northern hardwoods & 220.3 & 253.7 & 434.5 & 677.0 & 516.0 & 918.6 & $3,020.1$ & 2.7 \\
\hline Aspen/birch & 55.4 & 10.9 & 38.8 & 34.8 & 25.9 & 86.9 & 252.6 & 14.8 \\
\hline Total, all groups & 364.8 & 356.8 & 619.2 & 890.9 & 723.4 & $1,527.4$ & $4,482.5$ & 1.0 \\
\hline SE & 10.8 & 12.4 & 9.3 & 7.4 & 8.5 & 5.0 & 1.0 & \\
\hline
\end{tabular}

Table 7.--Area of timberland by forest-type group and cubic-foot stand-volume class of growing-stock trees, Vermont, 1997

(In thousands of acres)

\begin{tabular}{|c|c|c|c|c|c|c|c|c|}
\hline \multirow{2}{*}{$\begin{array}{c}\text { Forest-type } \\
\text { group }\end{array}$} & \multicolumn{6}{|c|}{ Stand-volume class (cubic feet per acre) } & \multirow{2}{*}{$\begin{array}{c}\text { All } \\
\text { classes }\end{array}$} & \multirow{2}{*}{ SE } \\
\hline & $\begin{array}{c}0- \\
499\end{array}$ & $\begin{array}{l}500- \\
999\end{array}$ & $\begin{array}{l}1000- \\
.1499\end{array}$ & $\begin{array}{l}1500- \\
1999\end{array}$ & $\begin{array}{l}2000- \\
2499\end{array}$ & $2500+$ & & \\
\hline White/red pine & 27.3 & 11.9 & 41.9 & 80.5 & 61.9 & 268.1 & 491.7 & 9.7 \\
\hline Spruce/fir & 70.3 & 63.8 & 70.2 & 38.9 & 80.7 & 136.1 & 460.0 & 9.8 \\
\hline Oak/pine & .0 & 6.1 & 4.8 & 11.4 & 6.0 & 6.4 & 34.7 & 41.0 \\
\hline Oak/hickory & .1 & .0 & 39.9 & 24.6 & 34.3 & 64.1 & 163.1 & 19.5 \\
\hline Elm/ash/red maple & 16.3 & 18.4 & 4.3 & 18.0 & 3.2 & .0 & 60.2 & 29.1 \\
\hline Northern hardwoods & 260.3 & 337.3 & 485.6 & 652.7 & 523.7 & 760.4 & $3,020.1$ & 2.7 \\
\hline Aspen/birch & 55.4 & 10.9 & 45.1 & 41.5 & 25.5 & 74.2 & 252.6 & 14.8 \\
\hline Total, all groups & 429.7 & 448.4 & 691.9 & 867.7 & 735.4 & $1,309.4$ & $4,482.5$ & 1.0 \\
\hline SE & 10.0 & 11.0 & 8.7 & 7.5 & 8.5 & 5.6 & 1.0 & \\
\hline
\end{tabular}


Table 8.--Area of timberland by forest-type group and board-foot stand-volume class, Vermont, 1997

(In thousands of acres)

\begin{tabular}{|c|c|c|c|c|c|c|c|c|}
\hline \multirow{2}{*}{$\begin{array}{c}\text { Forest - type } \\
\text { group }\end{array}$} & \multicolumn{6}{|c|}{ Stand-volume class (board feet per acre) } & \multirow{2}{*}{$\begin{array}{c}\text { All } \\
\text { classes }\end{array}$} & \multirow{2}{*}{ SE } \\
\hline & $\begin{array}{l}0- \\
1999\end{array}$ & $\begin{array}{l}2000- \\
3999\end{array}$ & $\begin{array}{l}4000- \\
5999\end{array}$ & $\begin{array}{l}6000- \\
7999\end{array}$ & $\begin{array}{l}8000- \\
9999\end{array}$ & $10000+$ & & \\
\hline White/red pine & 45.7 & 45.2 & 73.8 & 113.4 & 53.3 & 160.3 & 491.7 & 9.7 \\
\hline spruce/fir & 172.2 & 101.9 & 42.7 & 96.0 & 19.8 & 27.4 & 460.0 & 9.8 \\
\hline Oak/pine & 11.0 & 6.4 & 6.0 & 11.4 & .0 & .0 & 34.7 & 41.0 \\
\hline Oak/hickory & 19.7 & 40.6 & 30.9 & 36.9 & 13.8 & 21.2 & 163.1 & 19.5 \\
\hline Elm/ash/red maple & 39.6 & 4.3 & 13.1 & .0 & 3.2 & .0 & 60.2 & 29.1 \\
\hline Northern hardwoods & 745.9 & 728.9 & 574.7 & 366.4 & 271.3 & 332.9 & $3,020.1$ & 2.7 \\
\hline Aspen/birch & 113.9 & 44.9 & 17.3 & 52.8 & .0 & 23.7 & 252.6 & 14.8 \\
\hline Total, all groups & $1,148.0$ & 972.2 & 758.5 & 676.9 & 361.4 & 565.6 & $4,482.5$ & 1.0 \\
\hline SE & 6.0 & 7.1 & 8.3 & 8.6 & 12.8 & 9.5 & 1.0 & \\
\hline
\end{tabular}

Table 9.--Area of timberland by forest-type group and basal-area class, Vermont, 1997

(In thousands of acres)

\begin{tabular}{|c|c|c|c|c|c|c|c|c|c|}
\hline \multirow{2}{*}{$\begin{array}{c}\text { Forest-type } \\
\text { group }\end{array}$} & \multicolumn{6}{|c|}{ Basal area class (square feet per acre) } & \multirow{2}{*}{\multicolumn{2}{|c|}{$\begin{array}{c}\text { All } \\
\text { classes }\end{array}$}} & \multirow{2}{*}{ SE } \\
\hline & $\begin{array}{l}0- \\
49\end{array}$ & $\begin{array}{l}50- \\
99\end{array}$ & $\begin{array}{l}100- \\
149\end{array}$ & $\begin{array}{l}150- \\
199\end{array}$ & $\begin{array}{l}200- \\
249\end{array}$ & $\begin{array}{l}250- \\
299\end{array}$ & & & \\
\hline White/red pine & 18.9 & 88.3 & 157.3 & 169.1 & 45.8 & 7.3 & 5.0 & 491.7 & 9.7 \\
\hline Spruce/fir & 66.3 & 76.8 & 141.7 & 135.6 & 38.0 & 1.7 & .0 & 460.0 & 9.8 \\
\hline Oak/pine & .0 & 16.2 & 12.4 & .0 & 6.1 & .0 & .0 & 34.7 & 41.0 \\
\hline Oak/hickory & .0 & 27.4 & 98.0 & 29.4 & 8.1 & .0 & .1 & 163.1 & 19.5 \\
\hline Elm/ash/red maple & 14.5 & 27.2 & 15.3 & 3.2 & .0 & .0 & .0 & 60.2 & 29.1 \\
\hline Northern hardwoods & 225.9 & 991.5 & $1,352.5$ & 380.5 & 61.1 & 8.6 & .0 & $3,020.1$ & 2.7 \\
\hline Aspen/birch & 33.9 & 64.8 & 85.6 & 56.0 & 12.3 & .0 & .0 & 252.6 & 14.8 \\
\hline Total, all groups & 359.5 & $1,292.4$ & $1,862.8$ & 773.8 & 171.3 & 17.5 & 5.1 & $4,482.5$ & 1.0 \\
\hline SE & 11.3 & 5.9 & 4.4 & 8.0 & 17.3 & 49.4 & 96.2 & 1.0 & \\
\hline
\end{tabular}


Table 10.--Area of timberland by forest-type group and stocking class of all live trees, Vermont, 1983

(In thousands of acres)

\begin{tabular}{|c|c|c|c|c|c|c|c|}
\hline \multirow{2}{*}{$\begin{array}{c}\text { Forest-type } \\
\text { group }\end{array}$} & \multicolumn{5}{|c|}{ stocking class } & \multirow{2}{*}{$\begin{array}{c}\text { All } \\
\text { classes }\end{array}$} & \multirow{2}{*}{ SE } \\
\hline & Nonstocked & $\begin{array}{l}\text { Poorly } \\
\text { stocked }\end{array}$ & $\begin{array}{c}\text { Moderately } \\
\text { stocked }\end{array}$ & $\begin{array}{l}\text { Fully } \\
\text { stocked }\end{array}$ & $\begin{array}{l}\text { Over- } \\
\text { stocked }\end{array}$ & & \\
\hline White/red pine & .0 & 43.1 & 99.2 & 289.2 & 43.8 & 475.2 & 11.4 \\
\hline Spruce/fir & .0 & 75.8 & 188.6 & 219.9 & 7.4 & 491.6 & 10.6 \\
\hline Oak/pine & .0 & .0 & .0 & 14.0 & .0 & 14.0 & 70.7 \\
\hline oak/hickory & .0 & 22.5 & 42.6 & 92.0 & 6.7 & 163.9 & 20.1 \\
\hline Elm/ash/red maple & .0 & 52.9 & 56.1 & 23.4 & .0 & 132.4 & 22.4 \\
\hline Northern hardwoods & 5.6 & 117.9 & 551.2 & 1.859 .0 & 300.0 & $2,833.8$ & 3.0 \\
\hline Aspen/birch & .0 & 12.5 & 58.4 & 173.0 & 58.0 & 301.9 & 14.8 \\
\hline Total, all groups & 5.6 & 324.7 & 996.1 & $2,670.6$ & 415.9 & $4,412.9$ & .7 \\
\hline SE & 100.0 & 13.4 & 7.4 & 3.2 & 12.7 & .7 & \\
\hline
\end{tabular}

Table 11.--Area of timberland by forest-type group and stocking class of all l ive trees, Vermont, 1997

(In thousands of acres)

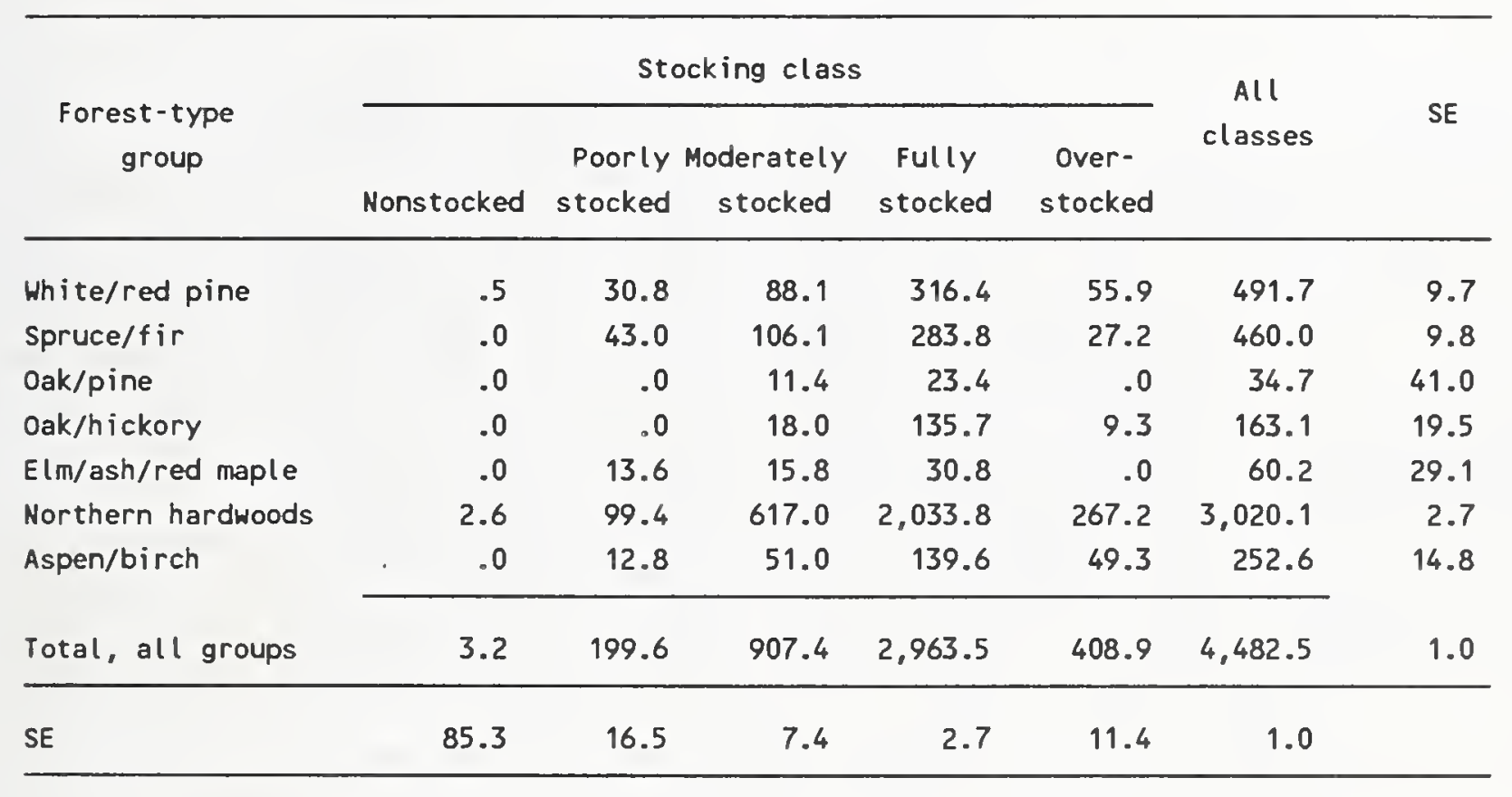


Table 12.--Area of timberland by forest-type group and stocking class of growing-stock trees, Vermont, 1983

(In thousands of acres)

\begin{tabular}{|c|c|c|c|c|c|c|c|}
\hline \multirow{2}{*}{$\begin{array}{c}\text { Forest-type } \\
\text { group }\end{array}$} & \multicolumn{5}{|c|}{ Stocking class } & \multirow{2}{*}{$\begin{array}{c}\text { All } \\
\text { classes }\end{array}$} & \multirow{2}{*}{ SE } \\
\hline & Nonstocked & $\begin{array}{l}\text { Poorly } \\
\text { stocked }\end{array}$ & $\begin{array}{c}\text { Moderately } \\
\text { stocked }\end{array}$ & $\begin{array}{l}\text { Fully } \\
\text { stocked }\end{array}$ & $\begin{array}{l}\text { Over- } \\
\text { stocked }\end{array}$ & & \\
\hline White/red pine & .0 & 93.2 & 186.3 & 181.0 & 14.7 & 475.2 & 11.4 \\
\hline Spruce/fir & .0 & 206.4 & 174.6 & 110.6 & .0 & 491.6 & 10.6 \\
\hline Oak/pine & .0 & .0 & 14.0 & .0 & .0 & 14.0 & 70.7 \\
\hline Oak/hickory & 14.9 & 35.7 & 49.1 & 64.2 & .0 & 163.9 & 20.1 \\
\hline Elm/ash/red maple & 5.0 & 55.2 & 55.9 & 16.3 & .0 & 132.4 & 22.4 \\
\hline Northern hardwoods & 66.7 & 539.1 & $1,171.6$ & $1,007.7$ & 48.6 & $2,833.8$ & 3.0 \\
\hline Aspen/birch & .0 & 47.0 & 124.2 & 108.7 & 22.0 & 301.9 & 14.8 \\
\hline Total, all groups & 86.5 & 976.7 & $1,775.9$ & $1,488.5$ & 85.3 & $4,412.9$ & .7 \\
\hline SE & 24.6 & 7.3 & 5.0 & 5.5 & 28.7 & .7 & \\
\hline
\end{tabular}

Table 13.--Area of timberland by forest-type group and stocking class of growing-stock trees, Vermont, 1997

(In thousands of acres)

\begin{tabular}{|c|c|c|c|c|c|c|c|}
\hline \multirow{2}{*}{$\begin{array}{c}\text { Forest-type } \\
\text { group }\end{array}$} & \multicolumn{5}{|c|}{ Stocking class } & \multirow{2}{*}{$\begin{array}{c}\text { All } \\
\text { classes }\end{array}$} & \multirow{2}{*}{ SE } \\
\hline & Nons tocked & $\begin{array}{l}\text { Poorly } \\
\text { stocked }\end{array}$ & $\begin{array}{c}\text { Moderately } \\
\text { stocked }\end{array}$ & $\begin{array}{l}\text { Fully } \\
\text { stocked }\end{array}$ & $\begin{array}{l}\text { Over- } \\
\text { stocked }\end{array}$ & & \\
\hline White/red pine & 5.9 & 46.9 & 155.9 & 263.6 & 19.4 & 491.7 & 9.7 \\
\hline Spruce/fir & 16.2 & 112.8 & 153.1 & 177.9 & .0 & 460.0 & 9.8 \\
\hline Oak/pine & .0 & 6.1 & 22.2 & 6.4 & .0 & 34.7 & 41.0 \\
\hline Oak/hickory & .1 & .0 & 60.5 & 101.0 & 1.4 & 163.1 & 19.5 \\
\hline Elm/ash/red maple & 9.7 & 25.6 & 25.0 & .0 & .0 & 60.2 & 29.1 \\
\hline Northern hardwoods & 54.3 & 482.4 & $1,062.3$ & $1,333.4$ & 87.7 & $3,020.1$ & 2.7 \\
\hline Aspen/birch & 24.5 & 53.4 & 89.1 & 79.8 & 5.8 & 252.6 & 14.8 \\
\hline Total, all groups & 110.6 & 727.2 & $1,568.1$ & $1,962.2$ & 114.4 & $4,482.5$ & 1.0 \\
\hline SE & 22.7 & 8.1 & 5.1 & 4.1 & 21.2 & 1.0 & \\
\hline
\end{tabular}


Timberland area by forest-type group and percent change, Vermont, 1983-97

Northern hardwoods

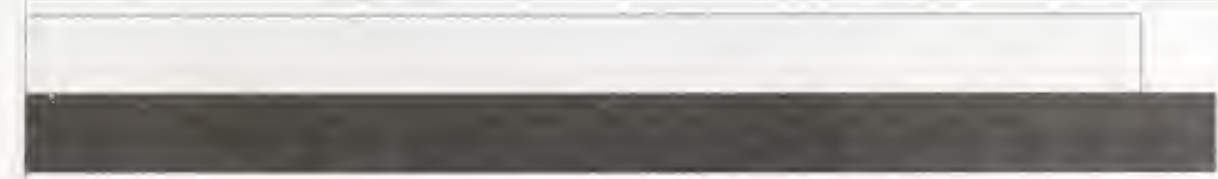

$+6.6 \%$

White /red pine

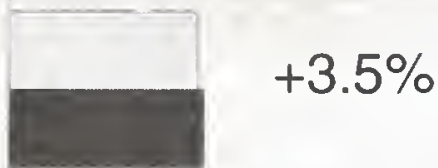

Spruce/fir

$-6.4 \%$

Aspen/birch

$-16.3 \%$

1983

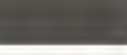

Oak/hickory

$-0.5 \%$

Other

$-35.2 \%$

0

0.5

1

1.5

2

2.5

3

3.5

Millions of acres 


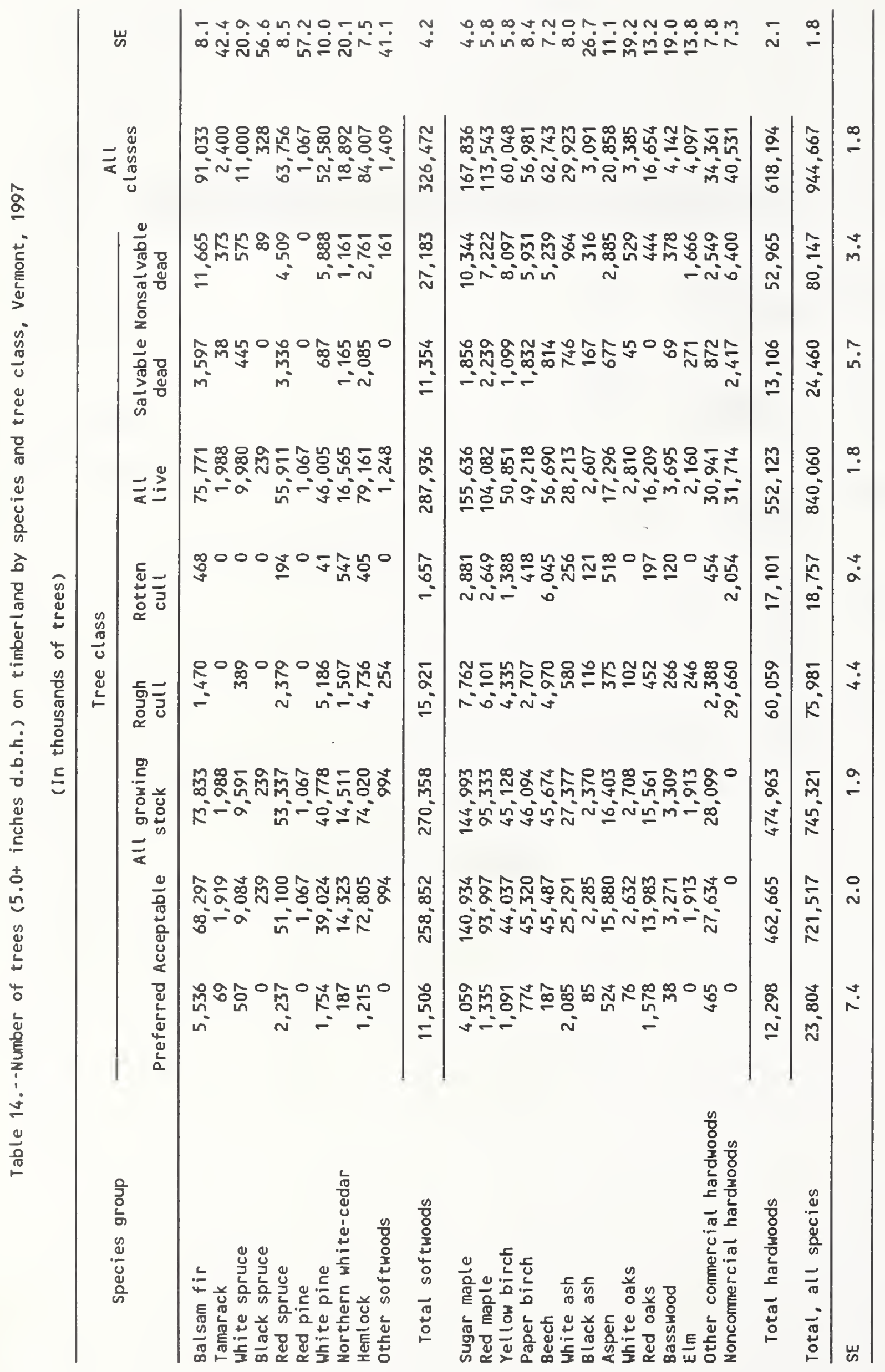




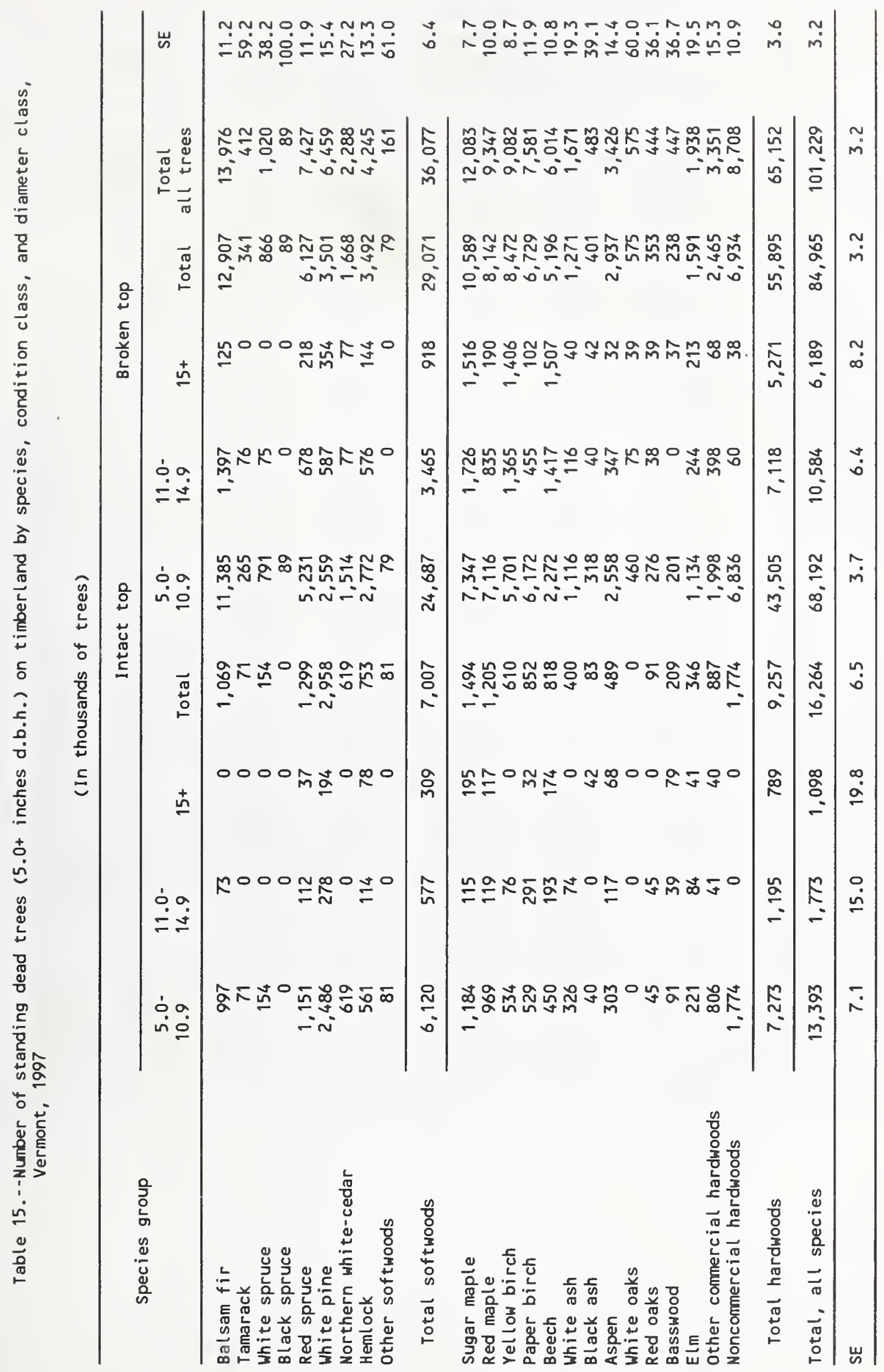


Table 16.--Number of seedlings, saplings, and shrubs on timberland by species and stand-size class, Vermont, 1997

(In thousands of stems)

\begin{tabular}{|c|c|c|c|c|c|c|}
\hline \multirow{2}{*}{ Species } & \multicolumn{4}{|c|}{ Stand-size class } & \multirow{2}{*}{$\begin{array}{c}\text { All } \\
\text { classes }\end{array}$} & \multirow{2}{*}{ SE } \\
\hline & $\begin{array}{l}\text { Saw- } \\
\text { timber }\end{array}$ & $\begin{array}{l}\text { Pole- } \\
\text { timber }\end{array}$ & $\begin{array}{l}\text { Sapling and } \\
\text { seedling }\end{array}$ & $\begin{array}{l}\text { Non- } \\
\text { stocked }\end{array}$ & & \\
\hline Balsam fir & 630,491 & 830,557 & 337,947 & 0 & $1,798,995$ & 9.6 \\
\hline Atlantic white cedar & 3,070 & 0 & 0 & 0 & 3,070 & 100.0 \\
\hline Larch & 522 & 0 & 3,643 & 0 & 4,165 & 62.1 \\
\hline Spruce species & 419,562 & 319,013 & 156,354 & 0 & 894,929 & 12.9 \\
\hline Eastern white pine & 36,593 & 11,366 & 11,891 & 0 & 59,851 & 21.2 \\
\hline Canada yew & 0 & 6,614 & 0 & 0 & 6,614 & 100.0 \\
\hline Northern white-cedar & 44,690 & 49,754 & 11,738 & 0 & 106,182 & 31.8 \\
\hline silver maple & 3,379 & 22,196 & 0 & 0 & 25,575 & 86.4 \\
\hline Sugar maple & $2,890,595$ & $1,048,284$ & 353,783 & 0 & $4,292,662$ & 8.4 \\
\hline Mountain maple & 318,706 & 159,888 & 82,125 & 0 & 560,719 & 17.4 \\
\hline Ailanthus species & 2,893 & 484 & 0 & 0 & 3,378 & 73.5 \\
\hline Alder species & 63,813 & 97,670 & 143,032 & 0 & 304,515 & 23.7 \\
\hline Serviceberry & 99,170 & 95,040 & 9,843 & 0 & 204,054 & 34.9 \\
\hline Chokeberry species & 9,522 & 6,456 & 0 & 0 & 15,978 & 72.0 \\
\hline Barberry & 88,046 & 9,781 & 22,998 & 0 & 120,825 & 44.3 \\
\hline Yellow birch & 794,068 & 357,186 & 102,075 & 0 & $1,253,330$ & 11.6 \\
\hline Sweet birch & 79,774 & 8,282 & 1,744 & 0 & 89,800 & 31.5 \\
\hline Paper birch & 210,064 & 117,755 & 141,035 & 0 & 468,854 & 15.7 \\
\hline Flowering dogwood & 15,148 & 0 & 0 & 0 & 15,148 & 100.0 \\
\hline Alternate-leaved dogwood & 55,979 & 27,072 & 11,505 & 0 & 94,556 & 30.5 \\
\hline silky dogwood & 0 & 0 & 11,430 & 0 & 11,430 & 71.4 \\
\hline Round-leaved dogwood & 12,054 & 1,681 & 6,398 & 0 & 20,133 & 68.3 \\
\hline Panicled dogwood & 196,057 & 85,067 & 75,443 & 0 & 356,567 & 34.1 \\
\hline Red-osier dogwood & 68,469 & 66,409 & 198,021 & 0 & 332,898 & 30.7 \\
\hline Hawthorn species & 23,069 & 12,776 & 9,916 & 0 & 45,760 & 26.5 \\
\hline American hazelnut & 0 & 5,171 & 8,052 & 0 & 13,223 & 56.9 \\
\hline Beaked hazelnut & 177,893 & 177,751 & 157,794 & 0 & 513,438 & 24.4 \\
\hline Leatherwood & 6,745 & 1,641 & 0 & 0 & $\cdot 8,386$ & 82.8 \\
\hline American beech & $1,772,732$ & 583,747 & 76,968 & 0 & $2,433,448$ & 6.8 \\
\hline Ash species & 0 & 9,819 & 0 & 0 & 9,819 & 100.0 \\
\hline White ash & 773,296 & 401,816 & 151,518 & 0 & $1,326,630$ & 9.3 \\
\hline Black ash & 9,763 & 27,358 & 15,238 & 0 & 52,359 & 35.4 \\
\hline Green ash & 1,027 & 726 & 0 & 0 & 1,754 & 71.7 \\
\hline Witch-hazel & 69,378 & 58,746 & 0 & 0 & 128,124 & 34.7 \\
\hline Large-leaved holly & 4,890 & 0 & 0 & 0 & 4,890 & 100.0 \\
\hline
\end{tabular}


Table 16.--continued

(In thousands of stems)

\begin{tabular}{|c|c|c|c|c|c|c|}
\hline \multirow{2}{*}{ Species } & \multicolumn{4}{|c|}{ Stand-size class } & \multirow{2}{*}{$\begin{array}{c}\text { All } \\
\text { classes }\end{array}$} & \multirow{2}{*}{ SE } \\
\hline & $\begin{array}{l}\text { Saw- } \\
\text { t imber }\end{array}$ & $\begin{array}{l}\text { Pole- } \\
\text { timber }\end{array}$ & $\begin{array}{l}\text { Sapling and } \\
\text { seedl ing }\end{array}$ & $\begin{array}{l}\text { Non- } \\
\text { stocked }\end{array}$ & & \\
\hline Winterberry holly & 80,501 & 0 & 68,689 & 0 & 149,189 & 59.3 \\
\hline Butternut & 6,321 & 0 & 0 & 0 & 6,321 & 60.8 \\
\hline Bush honeysuckle & 67,428 & 52,190 & 41,348 & 0 & 160,965 & 27.0 \\
\hline Apple species & 77,384 & 4,040 & 23,453 & 0 & 104,877 & 66.3 \\
\hline Mountain holly & 6,100 & 33,202 & 63,495 & 0 & 102,798 & 46.5 \\
\hline Eastern hophornbeam & 298,366 & 158,446 & 23,968 & 0 & 480,780 & 16.4 \\
\hline Balsam poplar & 3,405 & 5,207 & 19,356 & 0 & 27,967 & 64.1 \\
\hline Eastern cottonwood & 0 & 0 & 1,639 & 0 & 1,639 & 100.0 \\
\hline Bigtooth aspen & 6,878 & 9,952 & 9,432 & 0 & 26,262 & 44.3 \\
\hline Quaking aspen & 34,491 & 98,399 & 102,025 & 0 & 234,916 & 17.4 \\
\hline Pin cherry & 117,857 & 99,535 & 338,699 & 0 & 556,092 & 19.2 \\
\hline Black cherry & 399,575 & 327,032 & 112,579 & 0 & 839,186 & 13.1 \\
\hline Chokecherry & 88,473 & 36,239 & 190,611 & 0 & 315,323 & 26.6 \\
\hline White oak & 4,287 & 3,680 & 0 & 0 & 7,967 & 53.4 \\
\hline Bur oak & 454 & 0 & 0 & 0 & 454 & 100.0 \\
\hline Chestnut oak & 28,672 & 0 & 0 & 0 & 28,672 & 100.0 \\
\hline Northern red oak & 69,239 & 66,772 & 2,072 & 0 & 138,083 & 24.1 \\
\hline Buckthorn species & 92,641 & 23,637 & 22,203 & 0 & 138,482 & 36.4 \\
\hline Staghorn sumac & 3,054 & 0 & 1,591 & 0 & 4,645 & 57.7 \\
\hline Currant species & 22,834 & 34,933 & 6,775 & 0 & 64,542 & 38.5 \\
\hline Rose species & 3,148 & 0 & 6,223 & 0 & 9,371 & 58.0 \\
\hline Rubus species & $3,448,143$ & $2,667,360$ & $3,681,428$ & 0 & $9,796,932$ & 10.6 \\
\hline Willow species & 44,913 & 8,722 & 60,747 & 0 & 114,382 & 29.1 \\
\hline Black willow & 4,836 & 2,816 & 0 & 0 & 7.653 & 73.1 \\
\hline Crack willow & 0 & 5,399 & 0 & 0 & 5,399 & 100.0 \\
\hline American elderberry & 25,797 & 3,336 & 11,232 & 0 & 40,365 & 39.0 \\
\hline Red-berried alder & 4,879 & 32,445 & 1,601 & 0 & 38,924 & 48.5 \\
\hline American mountain ash & 16,246 & 3,188 & 4,211 & 0 & 23,645 & 44.2 \\
\hline European mountain ash & 0 & 6,061 & 0 & 0 & 6,061 & 80.9 \\
\hline Spirea species & 262,563 & 410,186 & 868,591 & 0 & $1,541,339$ & 22.3 \\
\hline American basswood & 10,604 & 8,584 & 1,761 & 0 & 20,949 & 45.4 \\
\hline American elm & 34,331 & 22,780 & 11,084 & 486 & 68,682 & 22.1 \\
\hline slippery elm & 3,260 & 0 & 0 & 0 & 3,260 & 100.0 \\
\hline Blueberry & 240,699 & 113,204 & 93,148 & 0 & 447,051 & 52.0 \\
\hline Viburnum species & 1,684 & 20,056 & 4,968 & 0 & 26,708 & 56.8 \\
\hline Maple-leaved viburnum & 22,132 & 35,917 & 0 & 0 & 58,049 & 51.4 \\
\hline Hobblebush viburnum & $2,389,933$ & 698,603 & 39,993 & 0 & $3,128,529$ & 11.4 \\
\hline Wild raisin & 45,395 & 14,955 & 27,830 & 0 & 88,180 & 40.3 \\
\hline Arrowwood & 0 & 49,207 & 0 & 0 & 49,207 & 54.1 \\
\hline Nannyberry & 5,293 & 111,458 & 0 & 0 & 116,752 & 95.6 \\
\hline Common prickly ash & 61,131 & 2,151 & 69,843 & 0 & 133,125 & 47.9 \\
\hline Unknown deciduous shrub & 8,961 & 2,821 & 108,254 & 0 & 120,037 & 83.5 \\
\hline Unknown evergreen shrub & 0 & 0 & 12,266 & 0 & 12,266 & 100.0 \\
\hline Unknown tree & 0 & 9,970 & 0 & 0 & 9,970 & 58.1 \\
\hline All species & $19,735,519$ & $, 145,943$ & $8,568,404$ & 486 & $39,450,351$ & 3.7 \\
\hline SE & 5.5 & 8.3 & 13.3 & 100.0 & 3.7 & \\
\hline
\end{tabular}




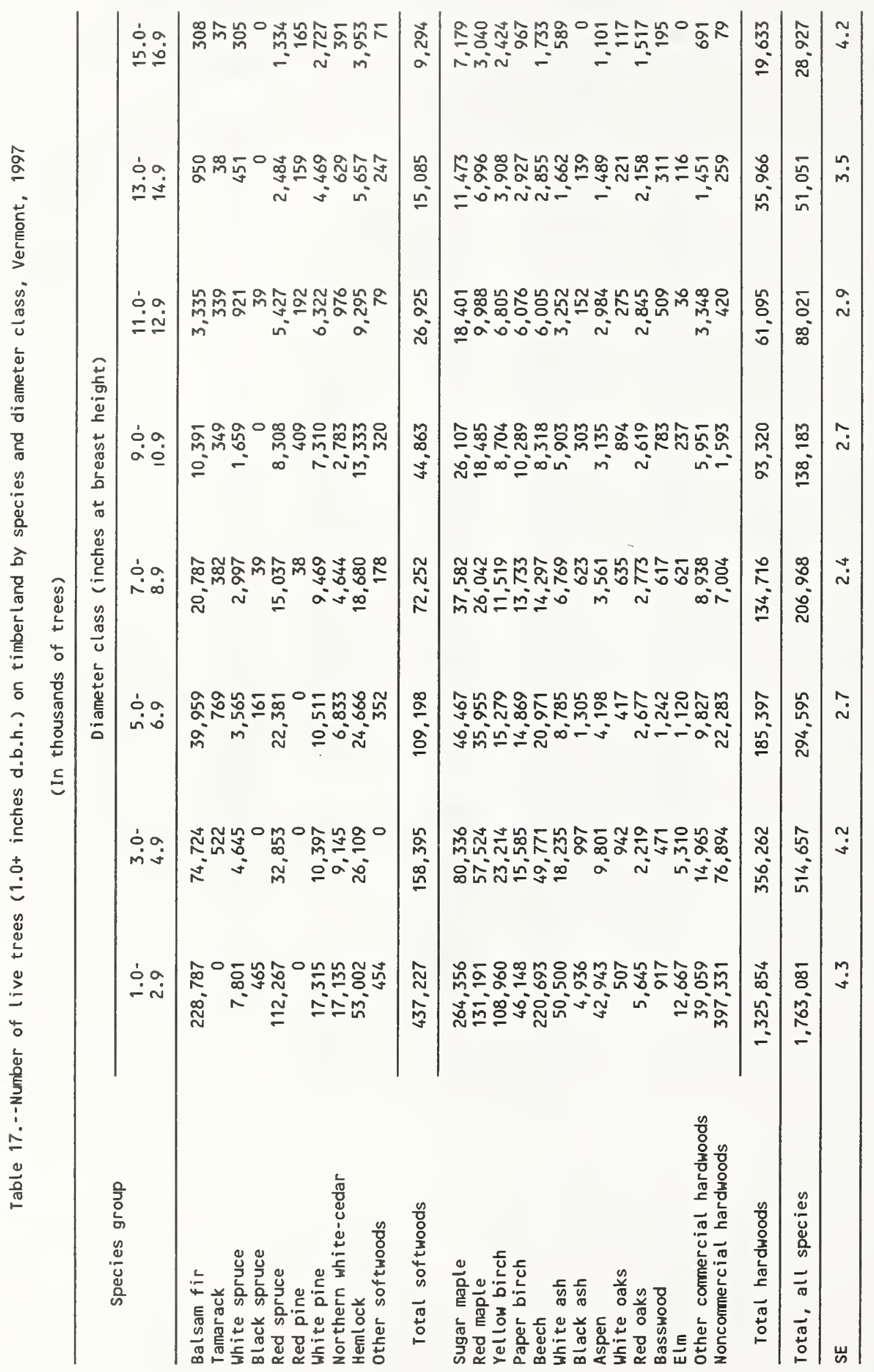




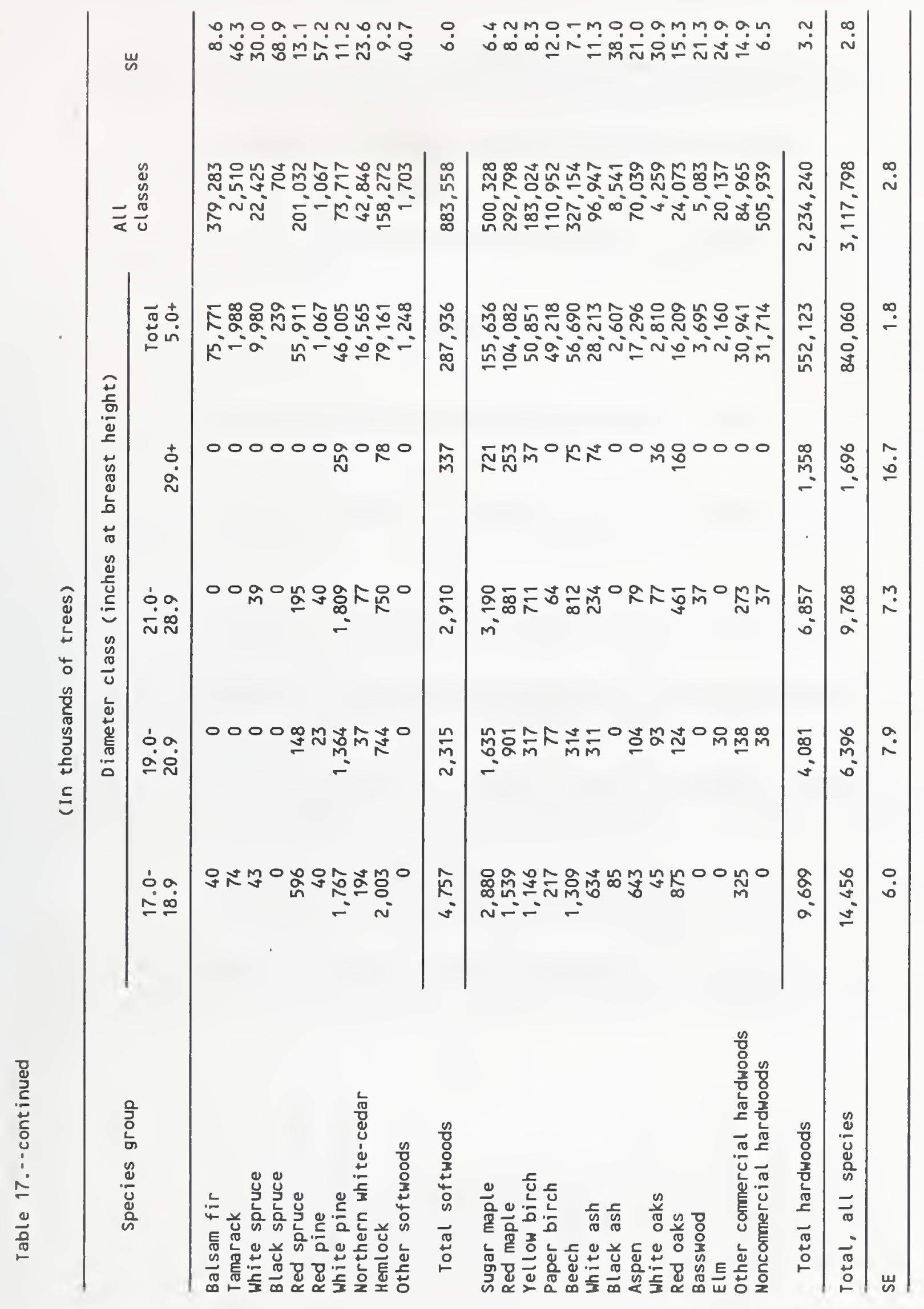




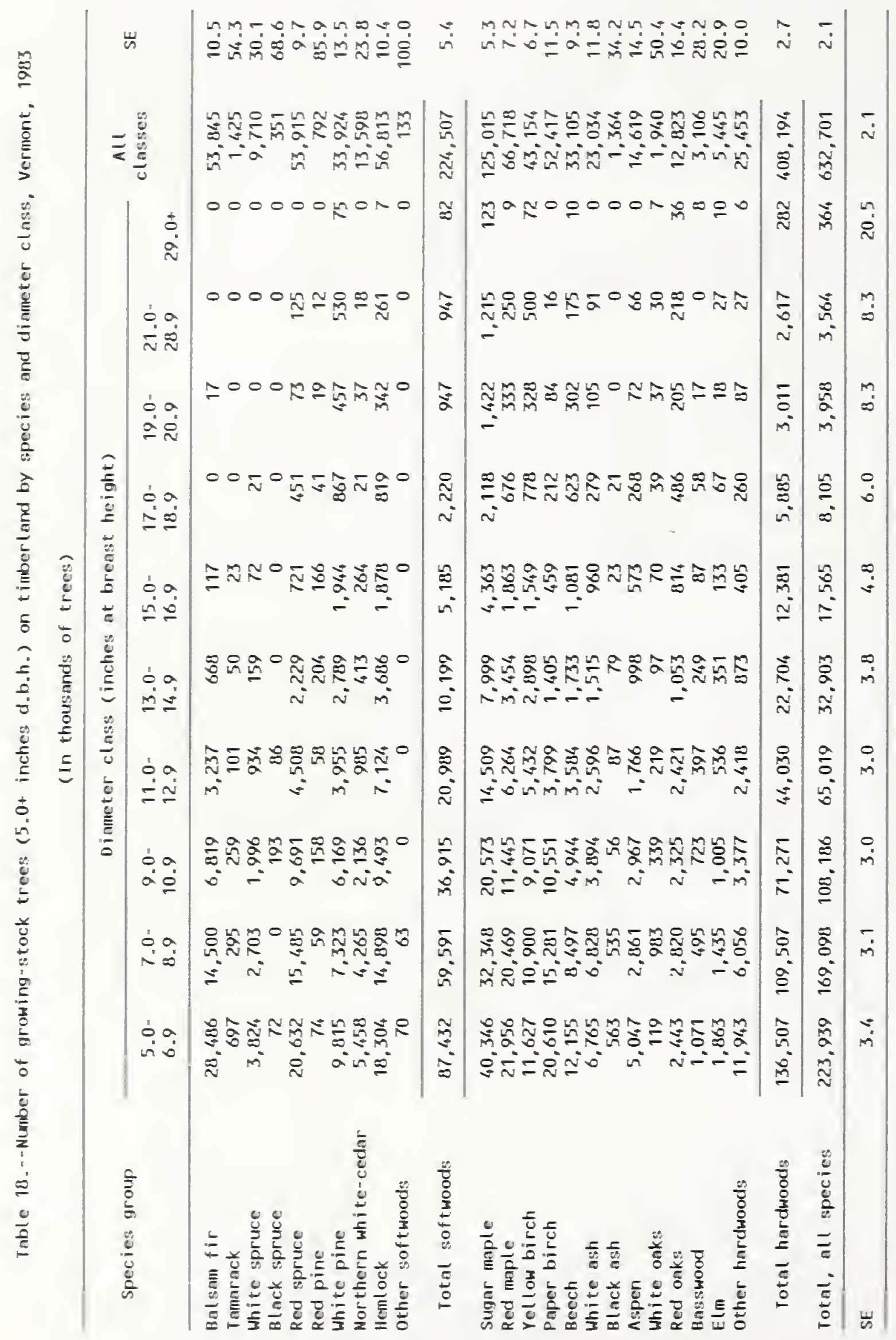




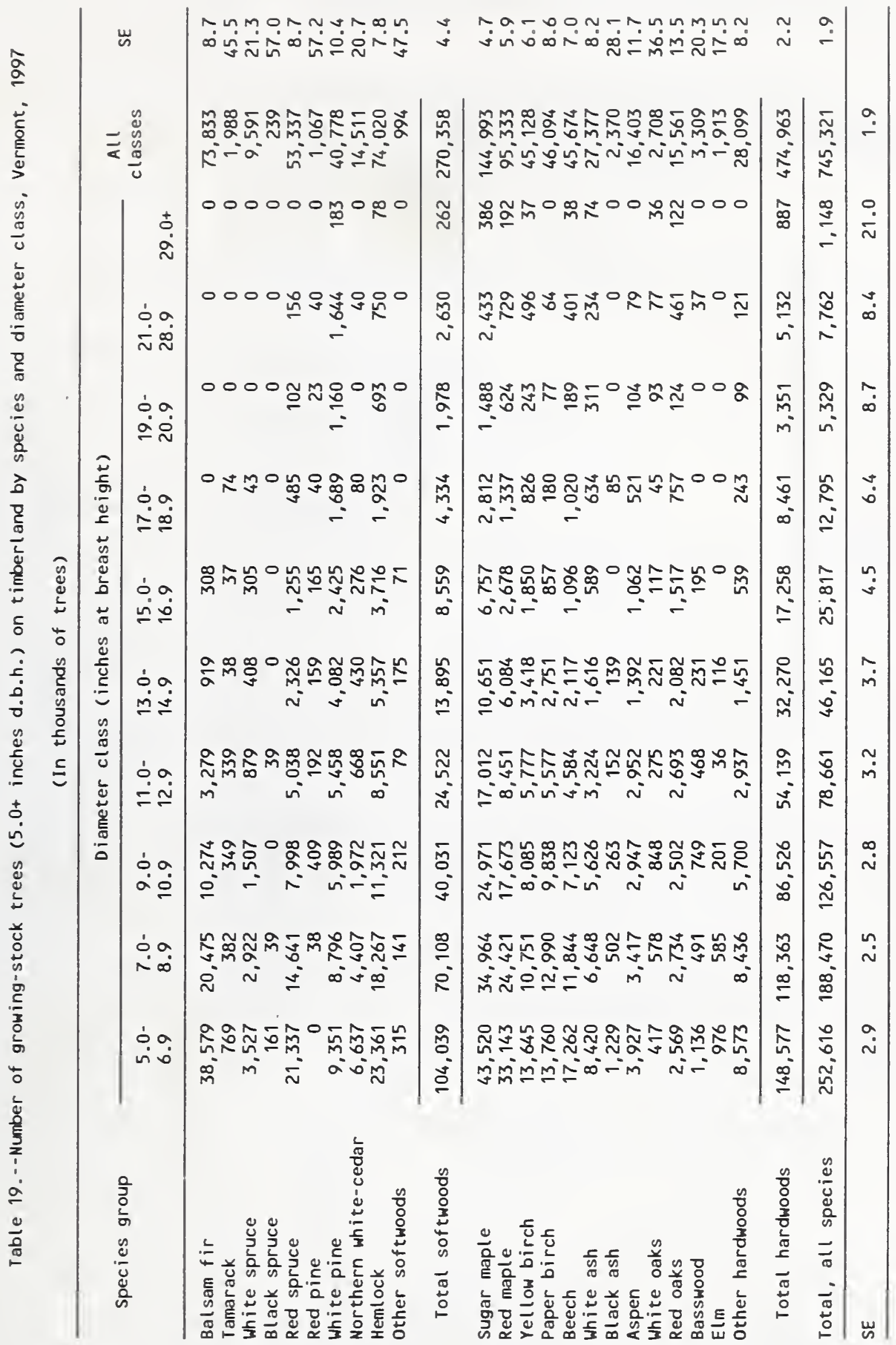




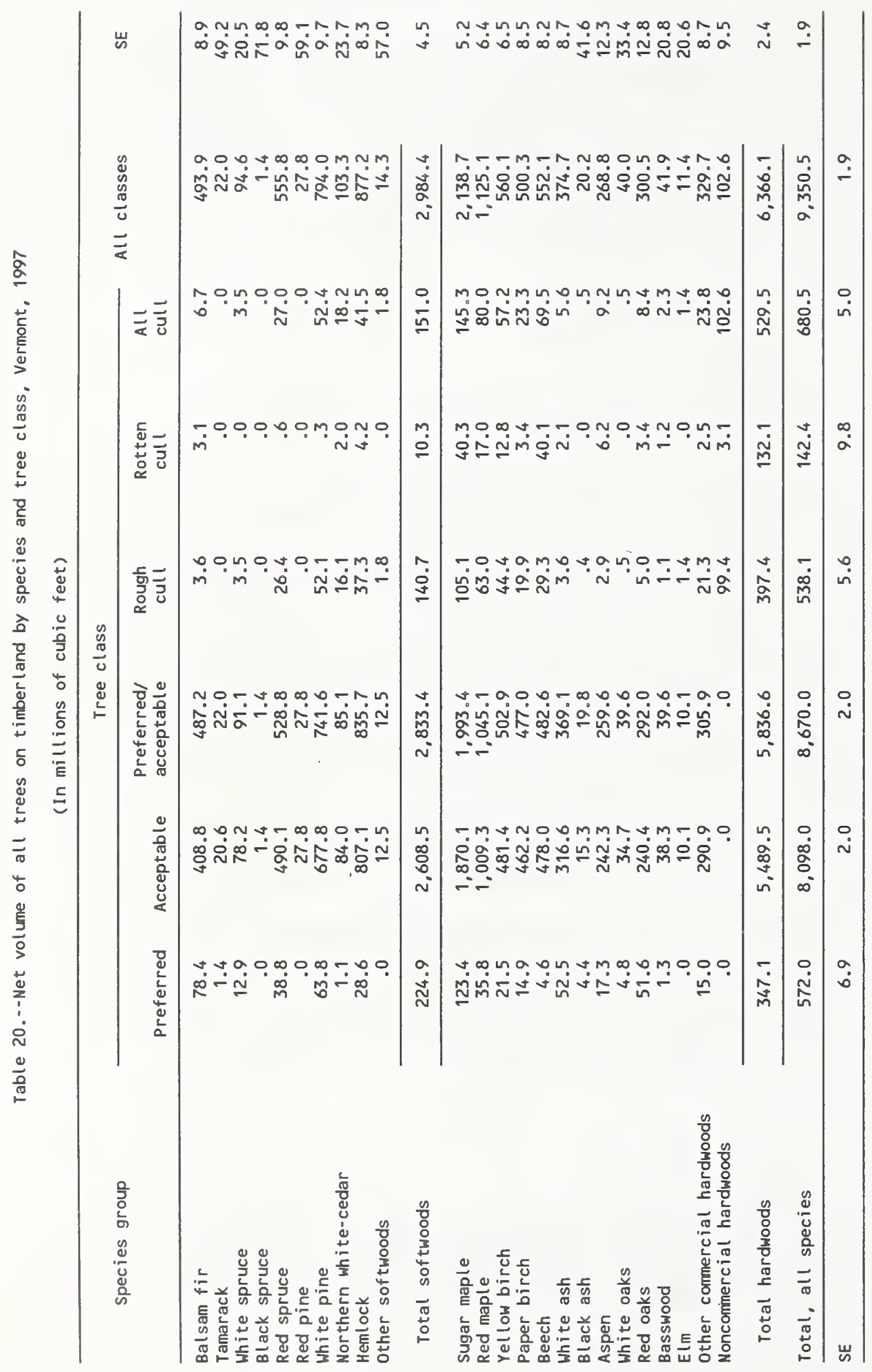


Volume of all live trees on timberland, for selected species and percent change, Vermont, 1983 and 1997

(Volume increased by 20.5 percent for all species)

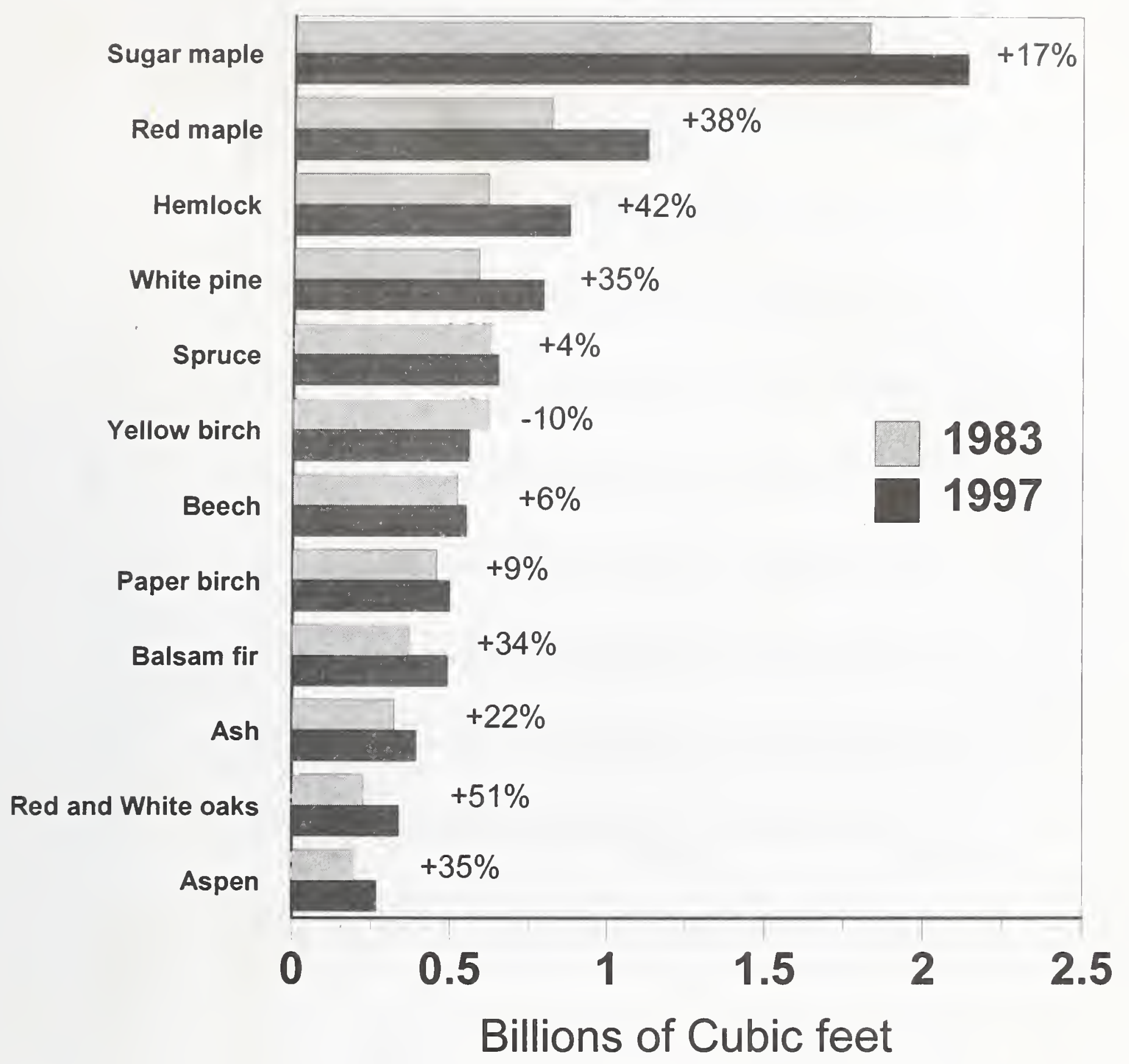




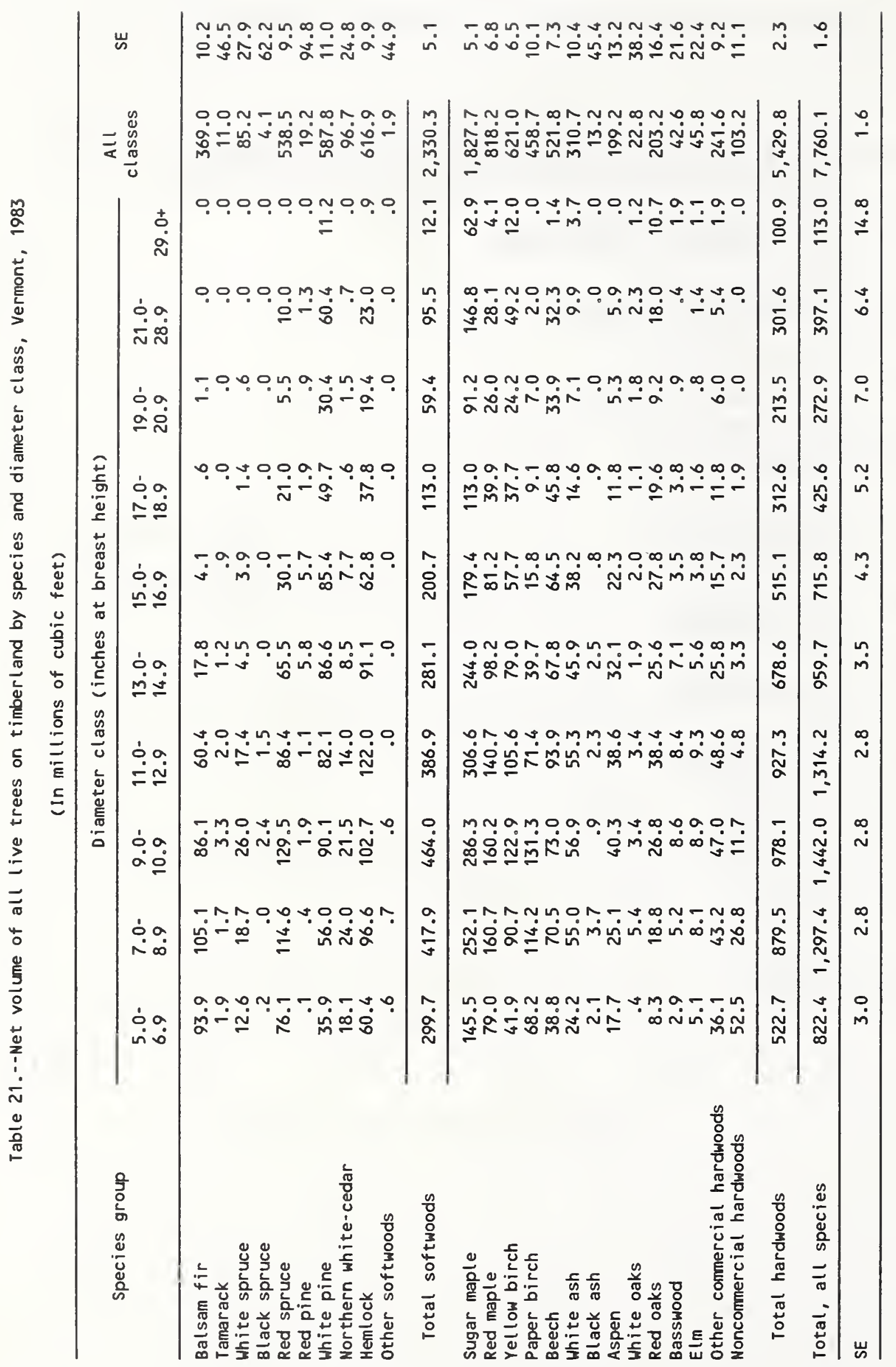




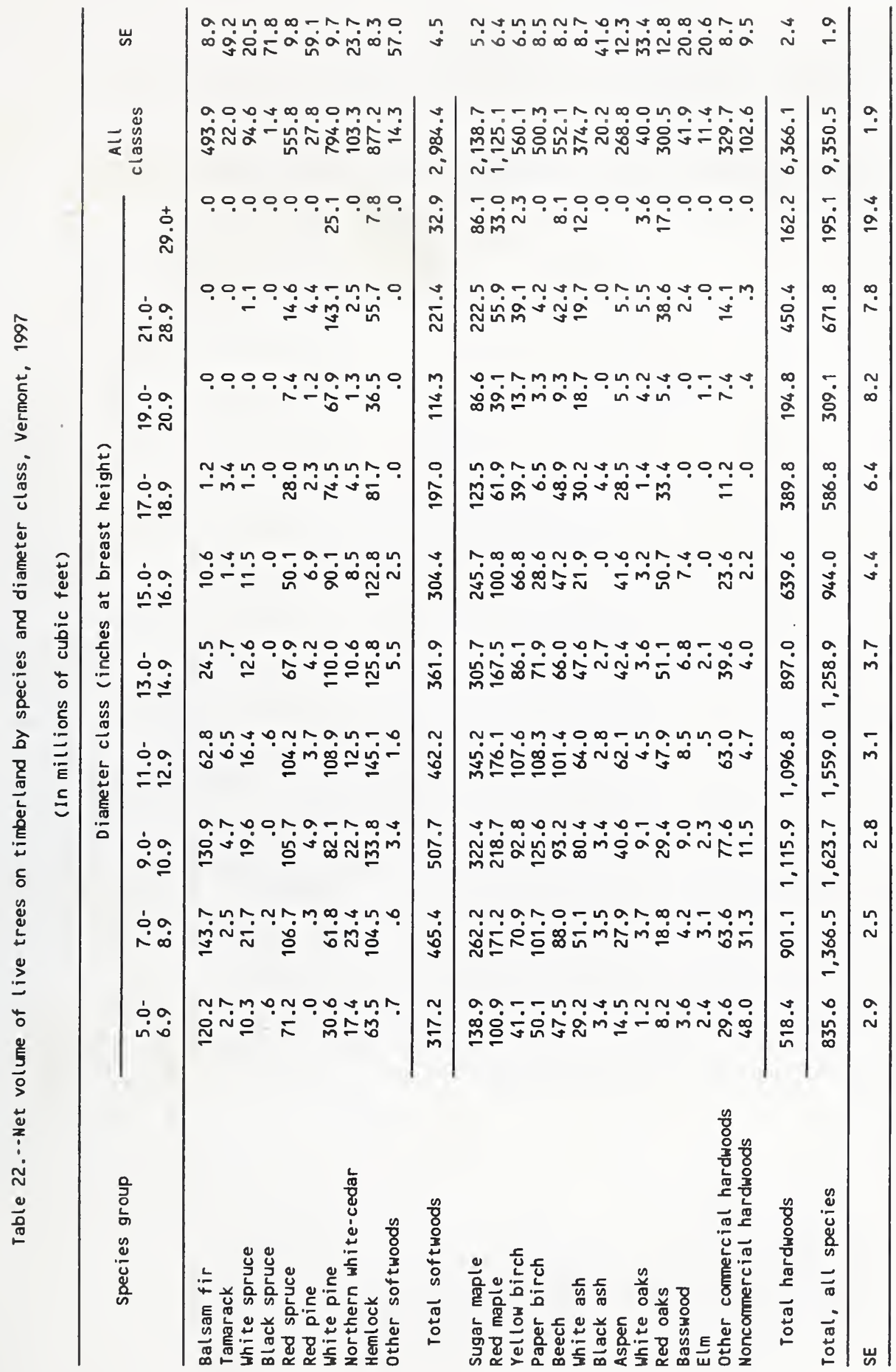




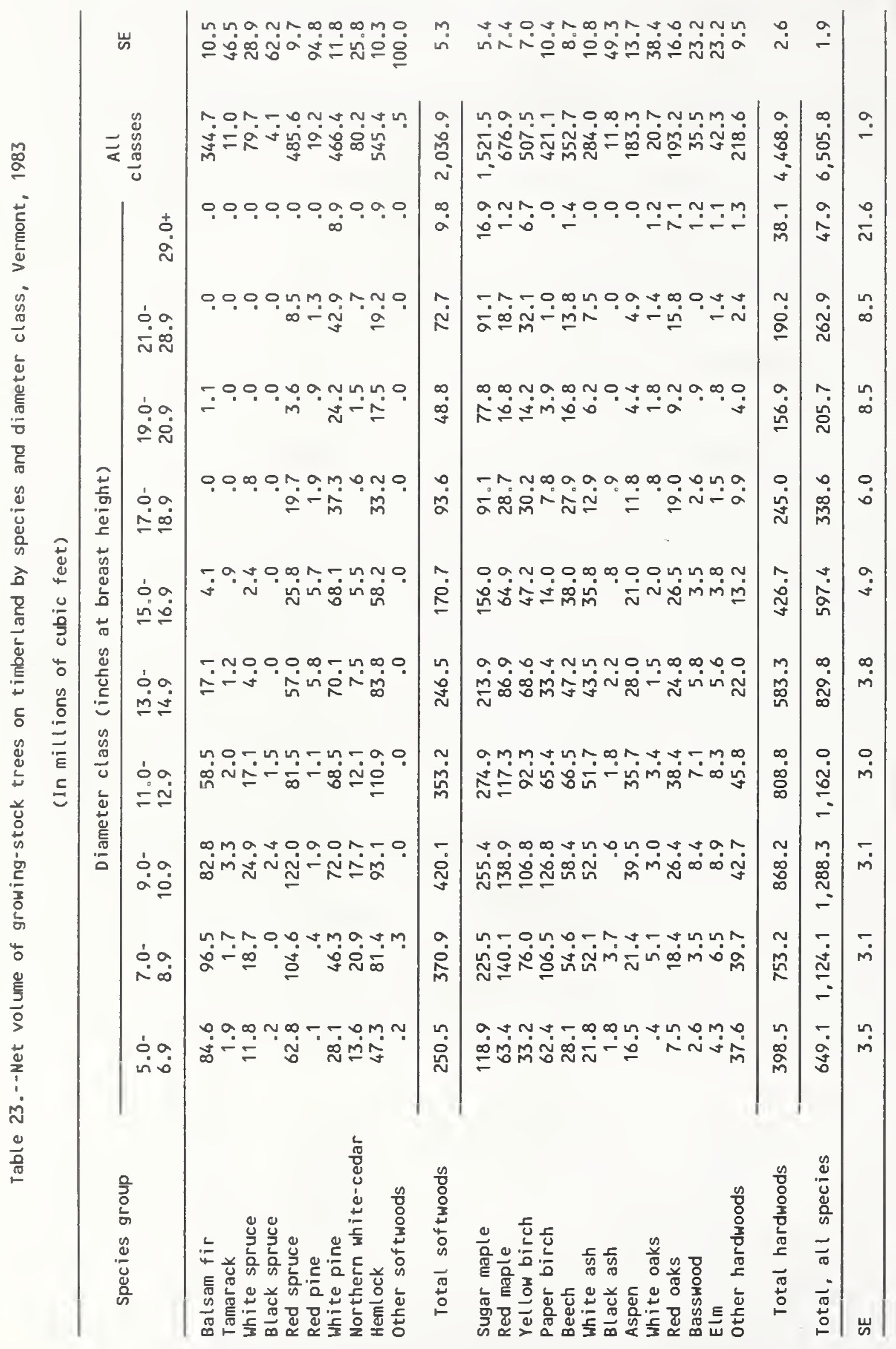




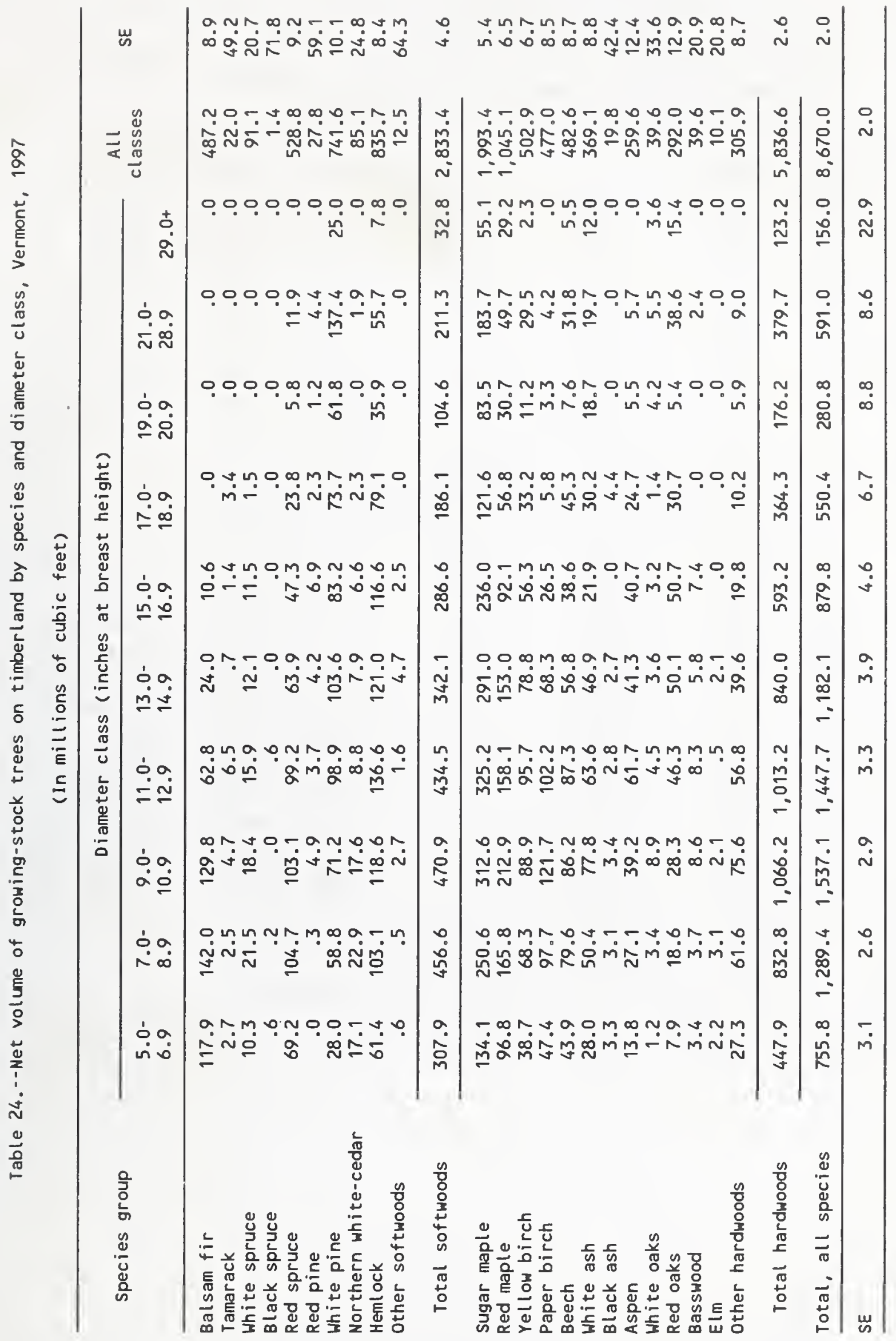


Table 25.--Net volume of growing-stock trees on timberland by species and stand-size class, Vermont, 1983

(In millions of cubic feet)

\begin{tabular}{|c|c|c|c|c|c|c|}
\hline \multirow{2}{*}{ Species group } & \multicolumn{4}{|c|}{ Stand-size class } & \multirow{2}{*}{$\begin{array}{c}\text { All } \\
\text { classes }\end{array}$} & \multirow{2}{*}{ SE } \\
\hline & $\begin{array}{l}\text { Sан- } \\
\text { timber }\end{array}$ & $\begin{array}{l}\text { Pole- } \\
\text { timber }\end{array}$ & $\begin{array}{l}\text { Sapling and } \\
\text { seedling }\end{array}$ & $\begin{array}{l}\text { Non- } \\
\text { stocked }\end{array}$ & & \\
\hline Balsam fir & $i 67.3$ & 169.9 & 7.5 & .0 & 344.7 & 10.5 \\
\hline Tamarack & 2.3 & 8.7 & .0 & .0 & 11.0 & 46.5 \\
\hline White spruce & 36.9 & 37.5 & 5.3 & .0 & 79.7 & 28.9 \\
\hline Black spruce & 2.3 & 1.8 & .0 & .0 & 4.1 & 62.2 \\
\hline Red spruce & 276.4 & 201.1 & 8.1 & .0 & 485.6 & 9.7 \\
\hline Red pine & 18.1 & 1.0 & .0 & .0 & 19.2 & 94.8 \\
\hline White pine & 310.4 & 138.2 & 17.9 & .0 & 466.4 & 11.8 \\
\hline Northern white-cedar & 49.4 & 26.7 & 4.1 & .0 & 80.2 & 25.8 \\
\hline Hemlock & 447.8 & 97.2 & .4 & .0 & 545.4 & 10.3 \\
\hline Other softwoods & .0 & .5 & .0 & .0 & .5 & 100.0 \\
\hline Total softwoods & $1,310.8$ & 682.7 & 43.4 & .0 & $2,036.9$ & 5.3 \\
\hline Sugar maple & $1,092.8$ & 419.6 & 9.1 & .0 & $1,521.5$ & 5.4 \\
\hline Red maple & 361.0 & 314.5 & 1.4 & .0 & 676.9 & 7.4 \\
\hline Yellow birch & 321.1 & 184.9 & 1.5 & .0 & 507.5 & 7.0 \\
\hline Paper birch & 134.1 & 285.0 & 2.0 & .0 & 421.1 & 10.4 \\
\hline Beech & 259.6 & 91.6 & 1.5 & .0 & 352.7 & 8.7 \\
\hline White ash & 117.0 & 164.7 & 2.4 & .0 & 284.0 & 10.8 \\
\hline Black ash & 7.5 & 3.8 & .4 & .0 & 11.8 & 49.3 \\
\hline Aspen & 83.4 & 94.2 & 5.7 & .0 & 183.3 & 13.7 \\
\hline White oaks & 5.0 & 15.0 & .6 & .0 & 20.7 & 38.4 \\
\hline Red oaks & 105.0 & 86.4 & 1.8 & .0 & 193.2 & 16.6 \\
\hline Basswood & 15.5 & 19.1 & .9 & .0 & 35.5 & 23.2 \\
\hline Elm & 21.2 & 19.9 & 1.2 & .0 & 42.3 & 23.2 \\
\hline Other hardwoods & 116.4 & 100.1 & 2.1 & .0 & 218.6 & 9.5 \\
\hline Total hardwoods & $2,639.5$ & $1,798.7$ & 30.7 & .0 & $4,468.9$ & 2.6 \\
\hline Total, all species & $3,950.3$ & $2,481.5$ & 74.1 & .0 & $6,505.8$ & 1.9 \\
\hline SE & 4.3 & 5.8 & 18.0 & .0 & 1.9 & \\
\hline
\end{tabular}


Table 26.--Net volume of growing-stock trees on timberland by species and stand-size class, Vermont, 1997

(In millions of cubic feet)

\begin{tabular}{|c|c|c|c|c|c|c|}
\hline \multirow{2}{*}{ Species group } & \multicolumn{4}{|c|}{ Stand-size class } & \multirow{2}{*}{$\begin{array}{c}\text { All } \\
\text { classes }\end{array}$} & \multirow{2}{*}{ SE } \\
\hline & $\begin{array}{l}\text { Saw- } \\
\text { timber }\end{array}$ & $\begin{array}{l}\text { Pole- } \\
\text { timber }\end{array}$ & $\begin{array}{l}\text { Sapling and } \\
\text { seedling }\end{array}$ & $\begin{array}{l}\text { Non- } \\
\text { stocked }\end{array}$ & & \\
\hline Balsam fir & 207.1 & 247.8 & 32.3 & .0 & 487.2 & 8.9 \\
\hline Tamarack & 19.7 & 1.8 & .5 & .0 & 22.0 & 49.2 \\
\hline White spruce & 57.4 & 27.7 & 6.0 & .0 & 91.1 & 20.7 \\
\hline Black spruce & .0 & .2 & 1.2 & .0 & 9.4 & 71.8 \\
\hline Red spruce & 363.5 & 153.7 & 11.6 & .0 & 528.8 & 9.2 \\
\hline Red pine & 21.6 & 1.3 & 4.9 & .0 & 27.8 & 59.1 \\
\hline White pine & 607.8 & 122.9 & 10.9 & .0 & 741.6 & 10.1 \\
\hline Northern white-cedar & 49.2 & 31.6 & 4.3 & .0 & 85.1 & 24.8 \\
\hline Hemlock & 780.7 & 52.2 & 2.8 & .0 & 835.7 & 8.4 \\
\hline Other sof twoods & 11.8 & .3 & .5 & .0 & 12.5 & 64.3 \\
\hline Total softwoods & $2,118.9$ & 639.6 & 74.9 & .0 & $2,833.4$ & 4.6 \\
\hline Sugar maple & $1,622.0$ & 355.9 & 15.6 & .0 & $1,993.4$ & 5.4 \\
\hline Red maple & 707.0 & 328.8 & 9.3 & .0 & $1,045.1$ & 6.5 \\
\hline Yellow birch & 389.1 & 112.2 & 1.7 & .0 & 502.9 & 6.7 \\
\hline Paper birch & 280.3 & 192.4 & 4.4 & .0 & 477.0 & 8.5 \\
\hline Beech & 408.5 & 65.5 & 8.6 & .0 & 482.6 & 8.7 \\
\hline White ash & 247.5 & 115.2 & 6.3 & .1 & 369.1 & 8.8 \\
\hline Black ash & 8.8 & 5.9 & 5.1 & .0 & 19.8 & 42.4 \\
\hline Aspen & 189.2 & 65.0 & 5.4 & .0 & 259.6 & 12.4 \\
\hline White oaks & 31.4 & 8.1 & .0 & .0 & 39.6 & 33.6 \\
\hline Red oaks & 220.6 & 71.5 & .0 & .0 & 292.0 & 12.9 \\
\hline Basswood & 35.1 & 4.5 & .0 & .0 & 39.6 & 20.9 \\
\hline$E l m$ & 6.0 & 2.9 & 1.1 & .0 & 10.1 & 20.8 \\
\hline Other hardwoods & 204.6 & 94.8 & 6.4 & .0 & 305.9 & 8.7 \\
\hline Total hardwoods & $4,350.0$ & $1,422.7$ & 63.9 & .1 & $5,836.6$ & 2.6 \\
\hline Total, all species & $6,468.9$ & $2,062.2$ & 138.8 & .9 & $8,670.0$ & 2.0 \\
\hline$S E$ & 3.3 & 6.6 & 16.0 & 100.0 & 2.0 & \\
\hline
\end{tabular}


Table 27.--Net volume of growing-stock trees on timberland by forest type and stand-size class, Vermont, 1997

(In millions of cubic feet)

\begin{tabular}{|c|c|c|c|c|c|c|}
\hline \multirow{2}{*}{ Forest type } & \multicolumn{4}{|c|}{ Stand-size class } & \multirow{2}{*}{$\begin{array}{c}\text { All } \\
\text { classes }\end{array}$} & \multirow{2}{*}{ SE } \\
\hline & $\begin{array}{l}\text { Saw- } \\
\text { timber }\end{array}$ & $\begin{array}{l}\text { Pole- } \\
\text { timber }\end{array}$ & $\begin{array}{l}\text { Sapling and } \\
\text { seedl ing }\end{array}$ & $\begin{array}{c}\text { Non- } \\
\text { stocked }\end{array}$ & & \\
\hline $\begin{array}{l}\text { Red pine } \\
\text { White pine } \\
\text { White pine/hemlock } \\
\text { Hemlock }\end{array}$ & $\begin{array}{r}17.3 \\
403.5 \\
194.0 \\
614.0\end{array}$ & $\begin{array}{r}1.3 \\
29.7 \\
20.9 \\
3.5\end{array}$ & $\begin{array}{r}.0 \\
.1 \\
4.4 \\
.0\end{array}$ & $\begin{array}{l}.0 \\
.0 \\
.0 \\
.0\end{array}$ & $\begin{array}{r}18.6 \\
433.2 \\
219.3 \\
617.5\end{array}$ & $\begin{array}{l}93.2 \\
21.5 \\
25.5 \\
15.8\end{array}$ \\
\hline White/red pine group & $1,228.8$ & 55.3 & 4.5 & .0 & $1,288.7$ & 11.0 \\
\hline $\begin{array}{l}\text { Balsam fir } \\
\text { Red spruce } \\
\text { Red spruce/balsam fir } \\
\text { White spruce } \\
\text { Black spruce } \\
\text { Norway spruce } \\
\text { Northern white-cedar } \\
\text { Tamarack }\end{array}$ & $\begin{array}{r}89.9 \\
109.3 \\
91.7 \\
59.8 \\
.0 \\
6.5 \\
67.9 \\
19.0\end{array}$ & $\begin{array}{r}218.2 \\
15.8 \\
93.1 \\
6.3 \\
.0 \\
.0 \\
29.6 \\
.0\end{array}$ & $\begin{array}{r}20.0 \\
.0 \\
12.3 \\
.0 \\
1.8 \\
.0 \\
.0 \\
.0\end{array}$ & $\begin{array}{l}.0 \\
.0 \\
.0 \\
.0 \\
.0 \\
.0 \\
.0 \\
.0\end{array}$ & $\begin{array}{r}328.1 \\
125.0 \\
197.1 \\
66.0 \\
1.8 \\
6.5 \\
97.4 \\
19.0\end{array}$ & $\begin{array}{r}18.1 \\
36.4 \\
25.5 \\
52.6 \\
100.0 \\
100.0 \\
40.3 \\
100.0\end{array}$ \\
\hline Spruce/fir group & 443.9 & 362.9 & 34.1 & .0 & 840.9 & 11.7 \\
\hline Wh. pine/no.red oak/wh. ash & 28.4 & 35.3 & .0 & .0 & 63.7 & 44.4 \\
\hline Oak/pine group & 28.4 & 35.3 & .0 & .0 & 63.7 & 44.4 \\
\hline $\begin{array}{l}\text { Chestnut oak } \\
\text { White oak/red oak/hickory } \\
\text { Northern red oak } \\
\text { Hawthorn/reverting field } \\
\text { Mixed central hardwoods }\end{array}$ & $\begin{array}{r}16.3 \\
33.0 \\
57.1 \\
.0 \\
150.5\end{array}$ & $\begin{array}{r}.0 \\
30.6 \\
19.5 \\
56.0\end{array}$ & $\begin{array}{l}.0 \\
.0 \\
.0 \\
1.8 \\
.0\end{array}$ & $\begin{array}{l}.0 \\
.0 \\
.0 \\
.0 \\
.0\end{array}$ & $\begin{array}{r}16.3 \\
63.6 \\
76.6 \\
1.8 \\
206.5\end{array}$ & $\begin{array}{r}100.0 \\
51.0 \\
44.9 \\
100.0 \\
28.8\end{array}$ \\
\hline Oak/hickory group & 256.9 & 106.2 & 1.8 & .0 & 364.8 & 20.8 \\
\hline $\begin{array}{l}\text { Black ash/Amer. elm/red maple } \\
\text { Red maple(upland) } \\
\text { Willow } \\
\text { American elm/green ash }\end{array}$ & $\begin{array}{r}19.4 \\
.0 \\
.0 \\
.0\end{array}$ & $\begin{array}{r}18.2 \\
9.9 \\
.0 \\
6.4\end{array}$ & $\begin{array}{r}8.3 \\
.0 \\
1.1 \\
.0\end{array}$ & $\begin{array}{l}.0 \\
.0 \\
.0 \\
.0\end{array}$ & $\begin{array}{r}45.9 \\
9.9 \\
1.1 \\
6.4\end{array}$ & $\begin{array}{r}43.9 \\
100.0 \\
71.1 \\
100.0\end{array}$ \\
\hline Elm/ash/red maple group & 19.4 & 34.5 & 9.4 & .0 & 63.3 & 36.5 \\
\hline $\begin{array}{l}\text { Sugar maple/beech/yellow birch } \\
\text { Black Cherry } \\
\text { Red maple/northern hardwoods } \\
\text { Pin cherry/reverting field } \\
\text { Mixed northern hardwoods }\end{array}$ & $\begin{array}{r}3,194.4 \\
.0 \\
572.2 \\
.0 \\
469.7\end{array}$ & $\begin{array}{r}726.4 \\
1.0 \\
334.2 \\
11.7 \\
234.8\end{array}$ & $\begin{array}{r}27.8 \\
.0 \\
21.3 \\
15.4 \\
14.2\end{array}$ & $\begin{array}{l}.0 \\
.0 \\
.0 \\
.1 \\
.0\end{array}$ & $\begin{array}{r}3,948.5 \\
1.0 \\
927.8 \\
27.2 \\
718.6\end{array}$ & $\begin{array}{r}4.8 \\
100.0 \\
12.2 \\
37.9 \\
14.5\end{array}$ \\
\hline Northern hardwoods group & $4,236.2$ & $1,308.0$ & 78.7 & .1 & $5,623.1$ & 3.5 \\
\hline $\begin{array}{l}\text { Aspen } \\
\text { Paper birch } \\
\text { Gray birch }\end{array}$ & $\begin{array}{r}103.8 \\
151.5 \\
.0\end{array}$ & $\begin{array}{r}45.5 \\
114.4 \\
.1\end{array}$ & $\begin{array}{r}8.6 \\
1.7 \\
.0\end{array}$ & $\begin{array}{l}.0 \\
.0 \\
.0\end{array}$ & $\begin{array}{r}157.9 \\
267.6 \\
.1\end{array}$ & $\begin{array}{l}30.0 \\
24.2 \\
76.7\end{array}$ \\
\hline Aspen/birch group & 255.3 & 160.0 & 10.2 & .0 & 425.6 & 18.7 \\
\hline All forest types & $6,468.9$ & $2,062.2$ & 138.8 & .1 & $8,670.0$ & 2.0 \\
\hline SE & 3.3 & 6.6 & 16.0 & 100.0 & 2.0 & \\
\hline
\end{tabular}


Percent of growing-stock volume by forest-type group Vermont, 1997

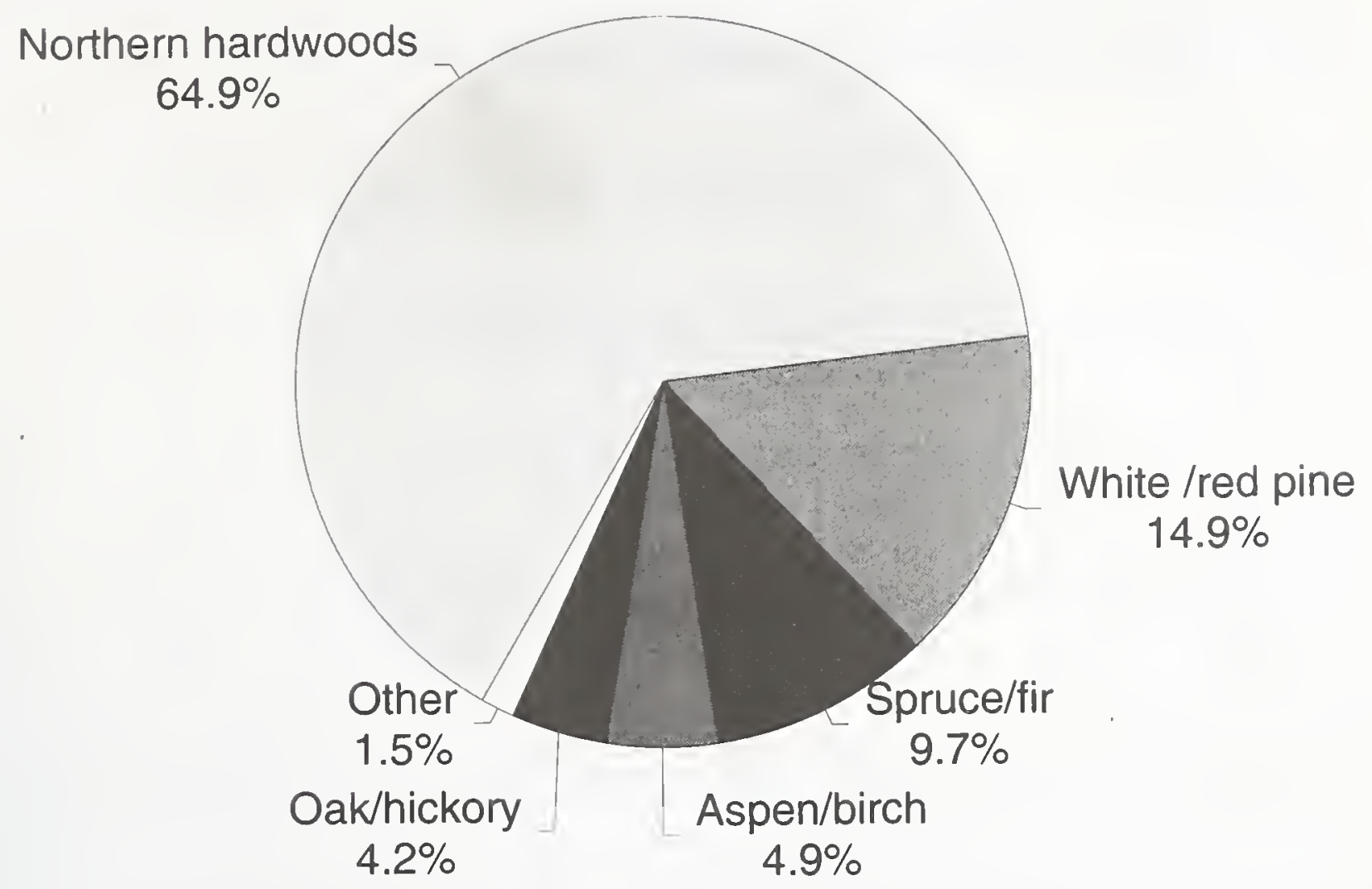




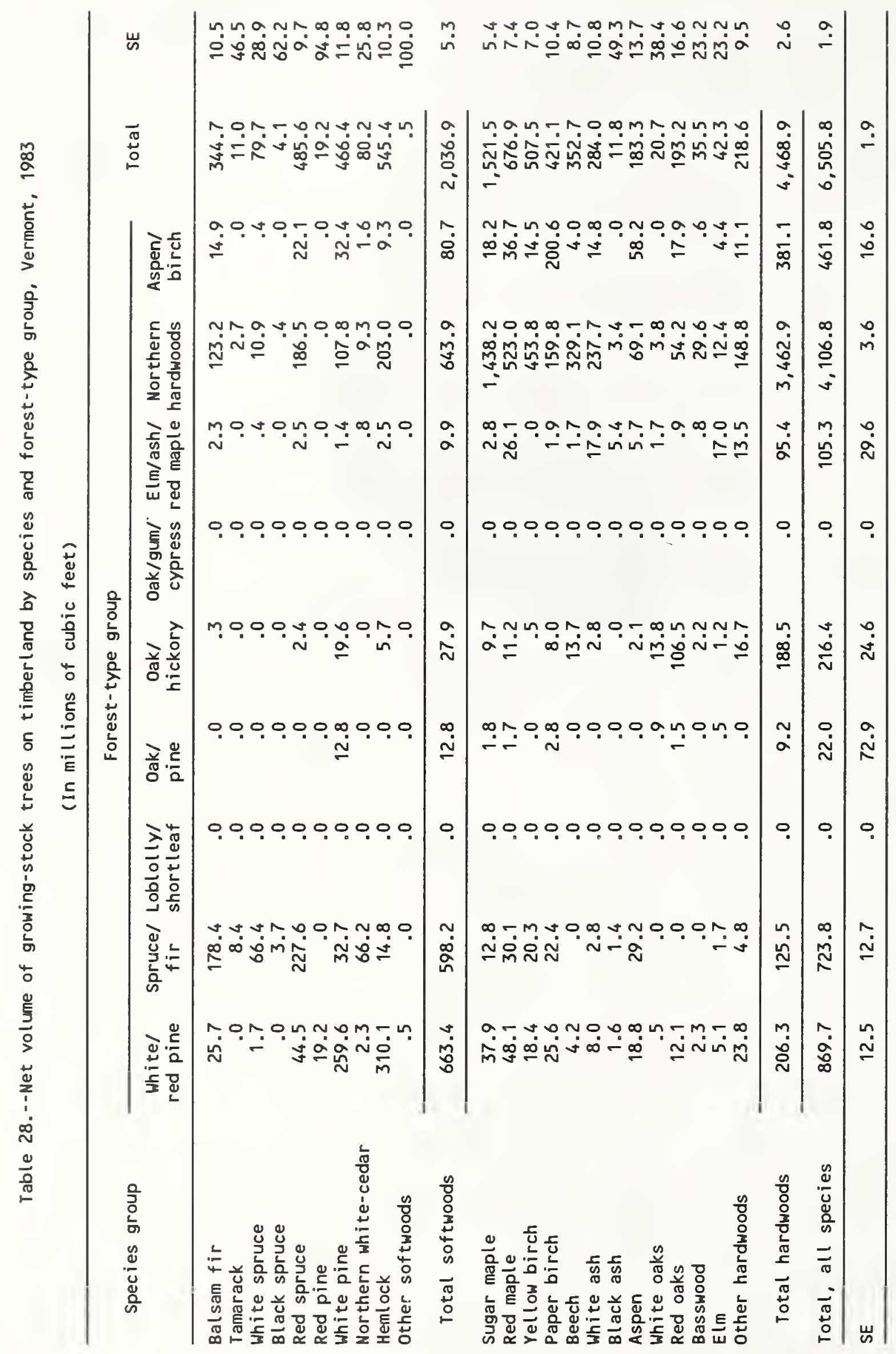




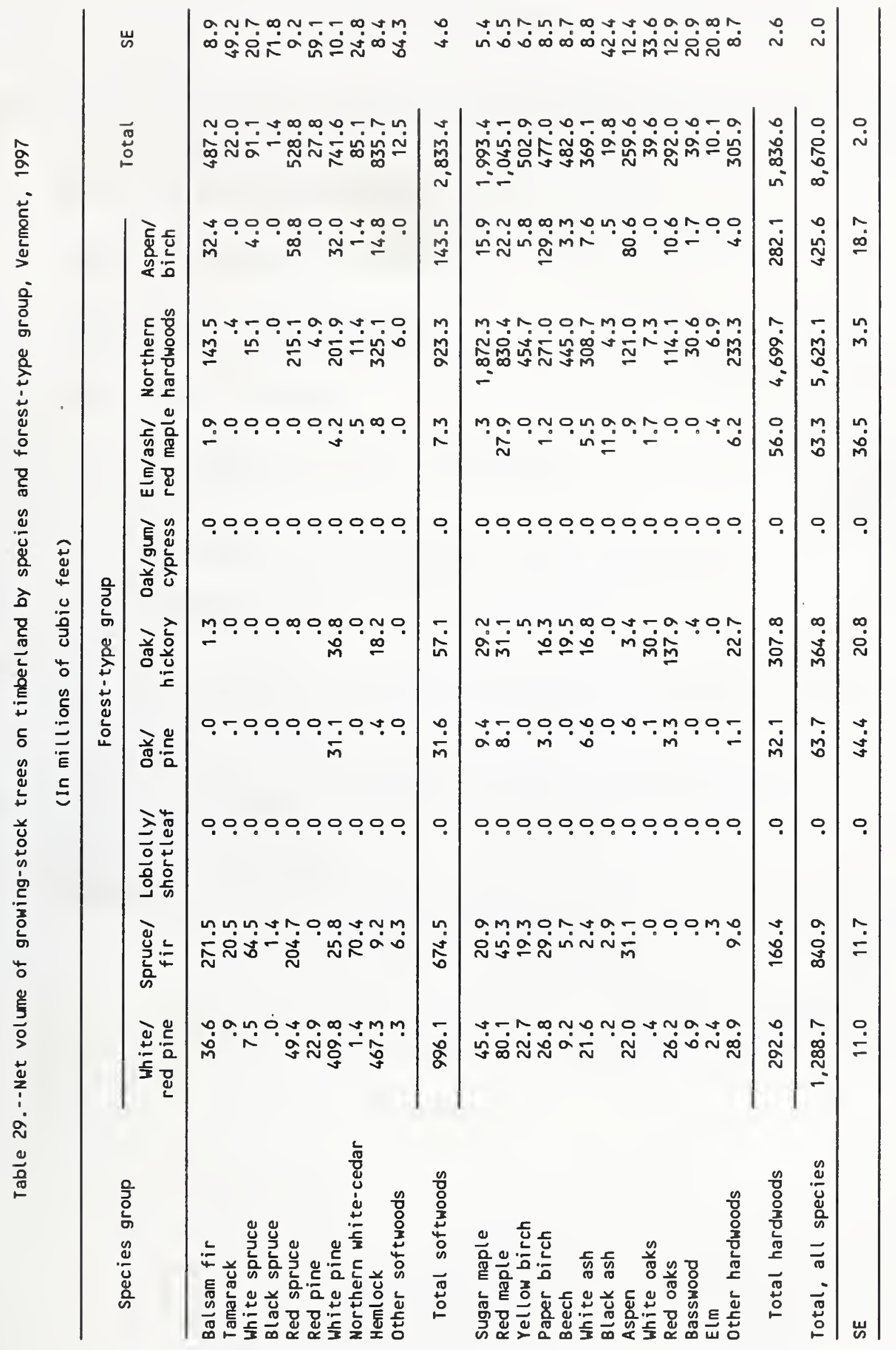




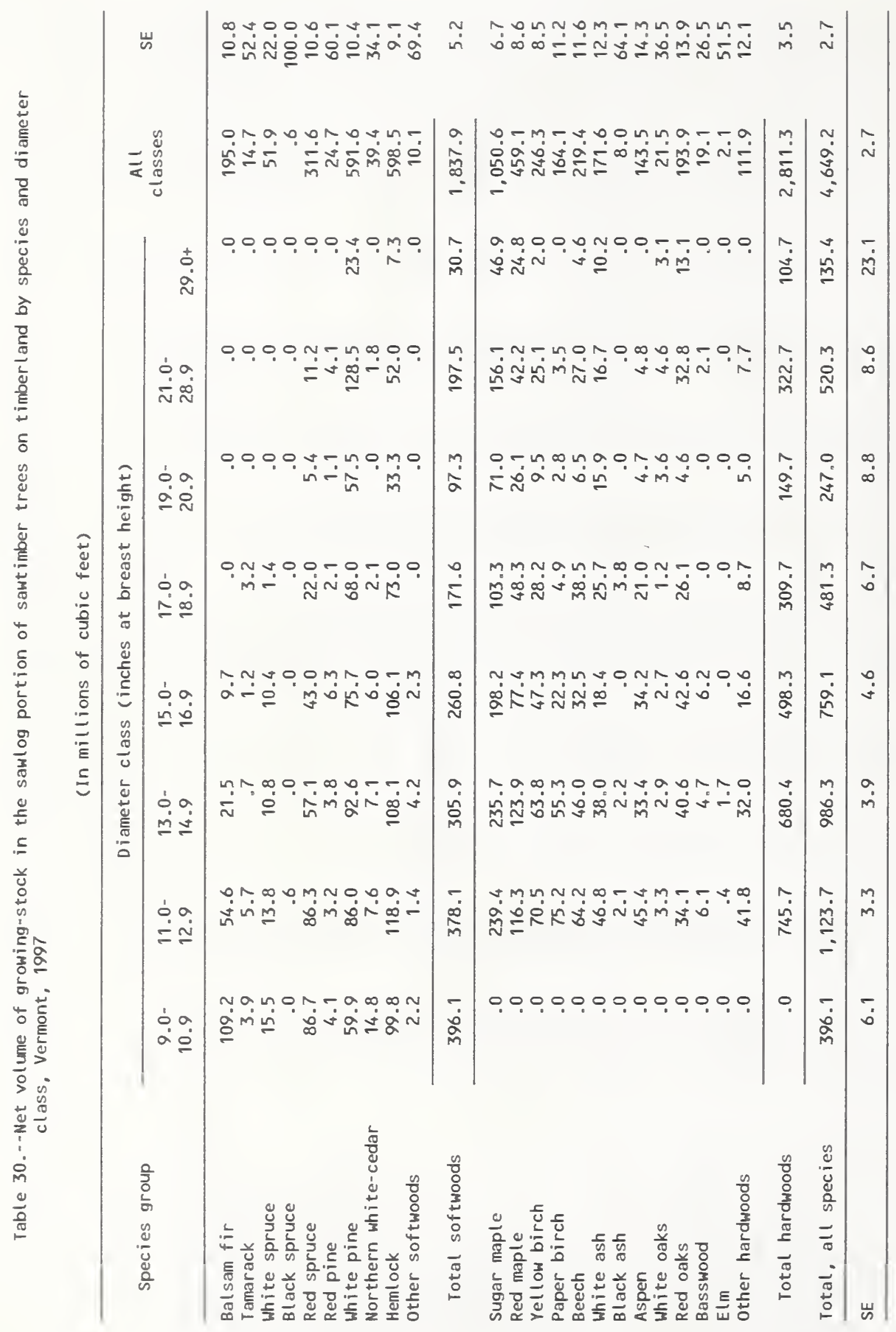


Sawtimber volume on timberland, for selected species and percent change, Vermont, 1983 and 1997

(Volume increased by 47.4 percent for all species)

Sugar maple

White pine

Hemlock

Red maple

Spruce

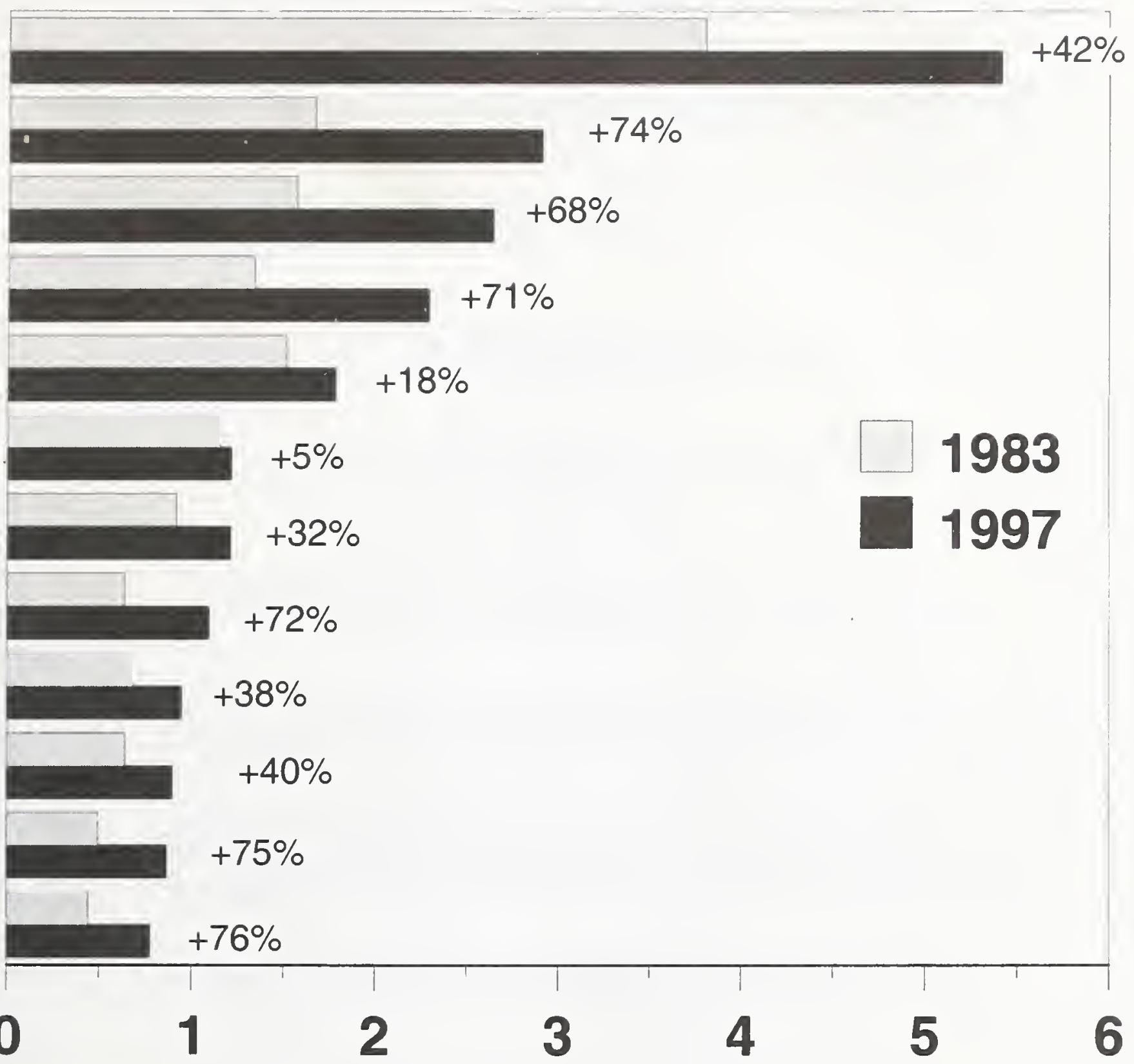

Yellow birch

Beech

Oaks

Ash

Balsam fir

Paper birch

Aspen

Billions of board feet 


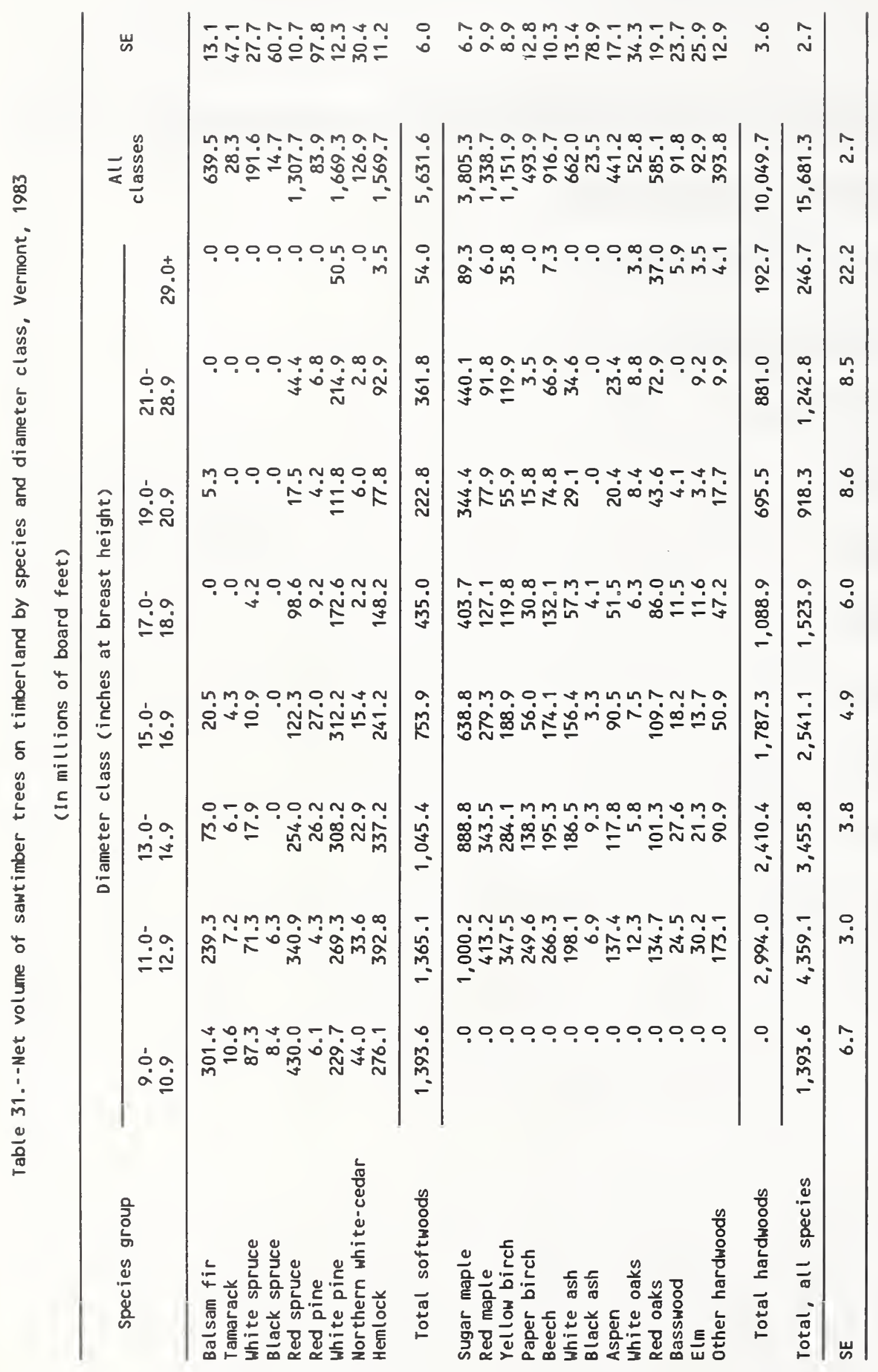




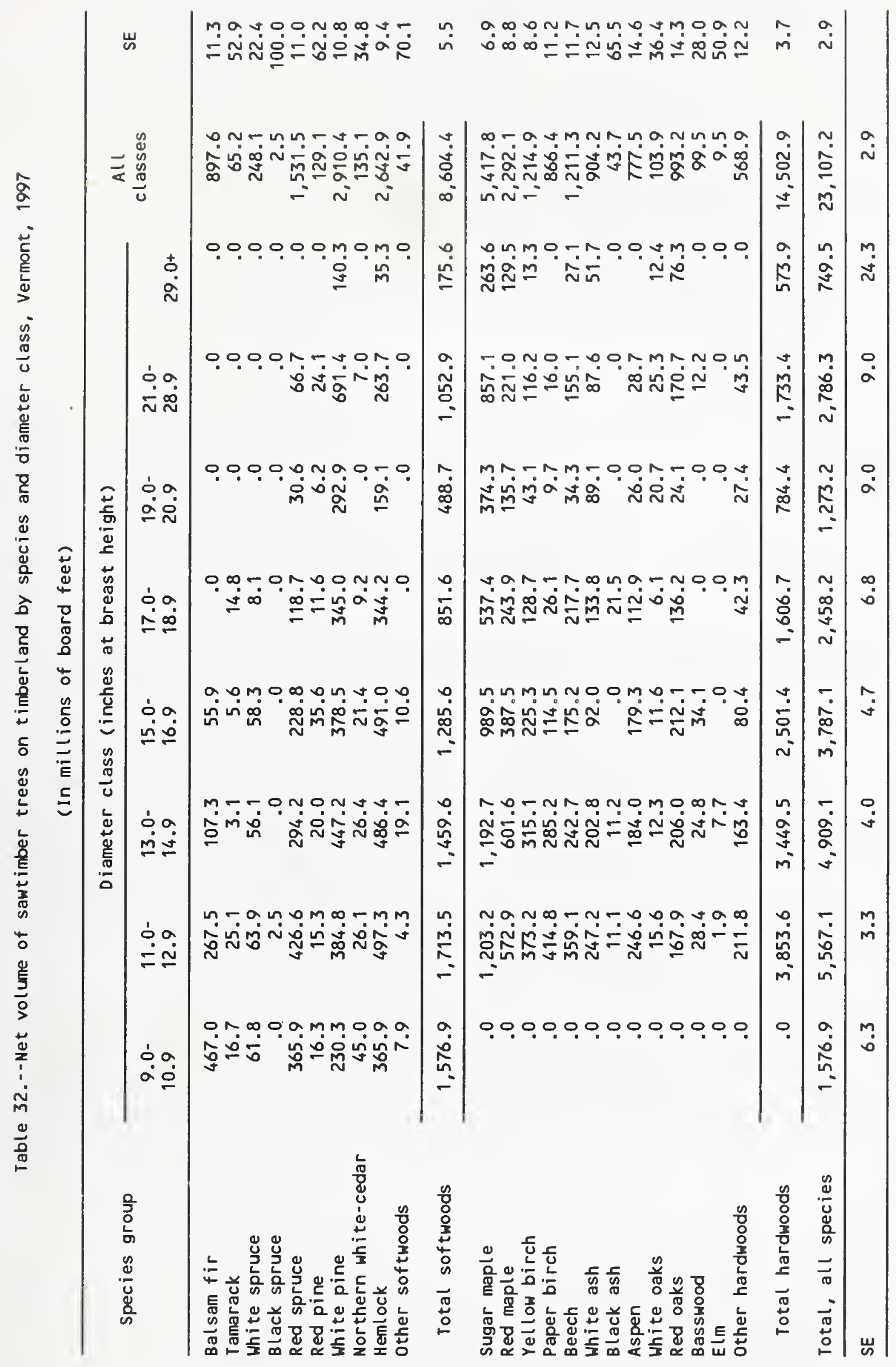




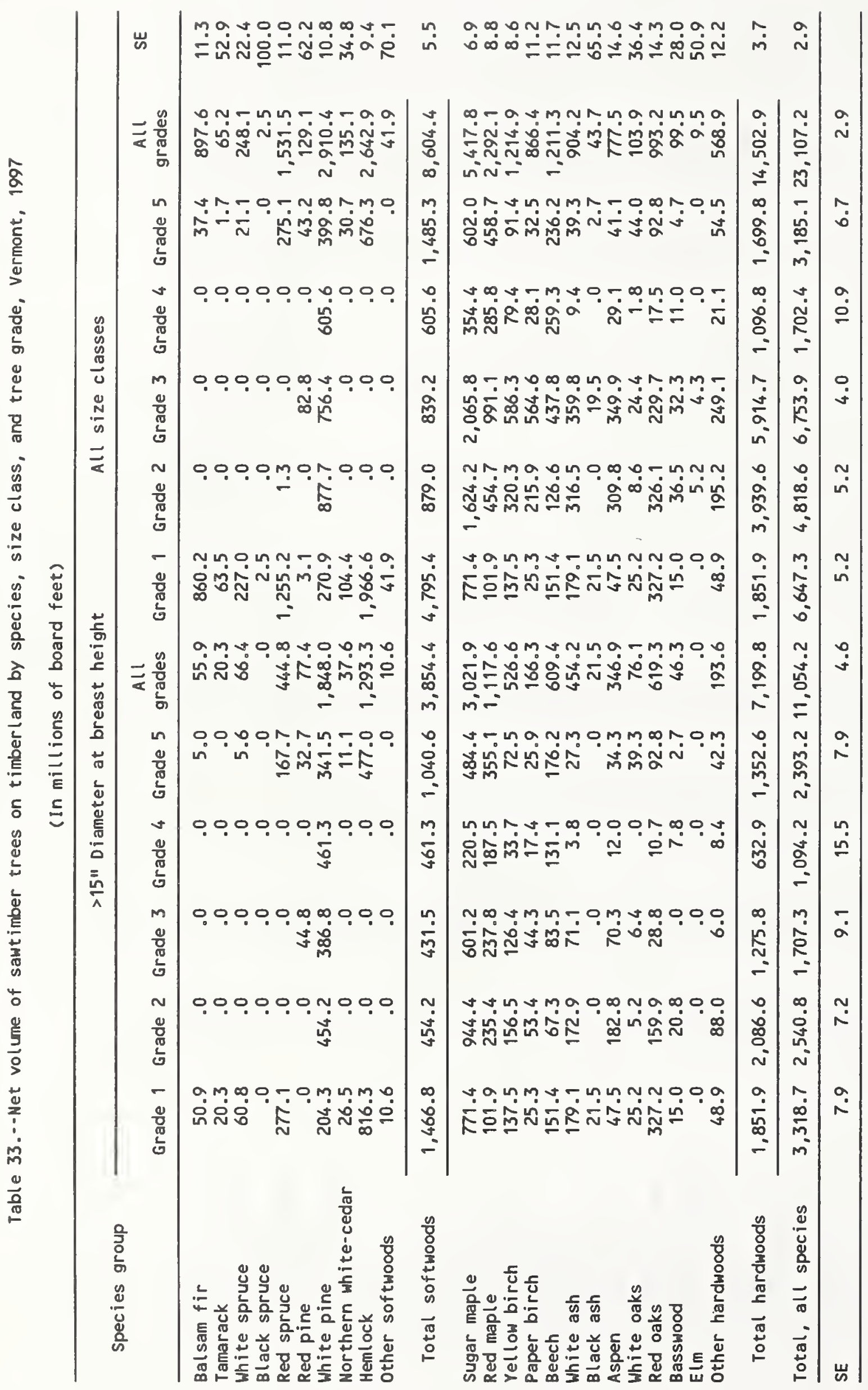




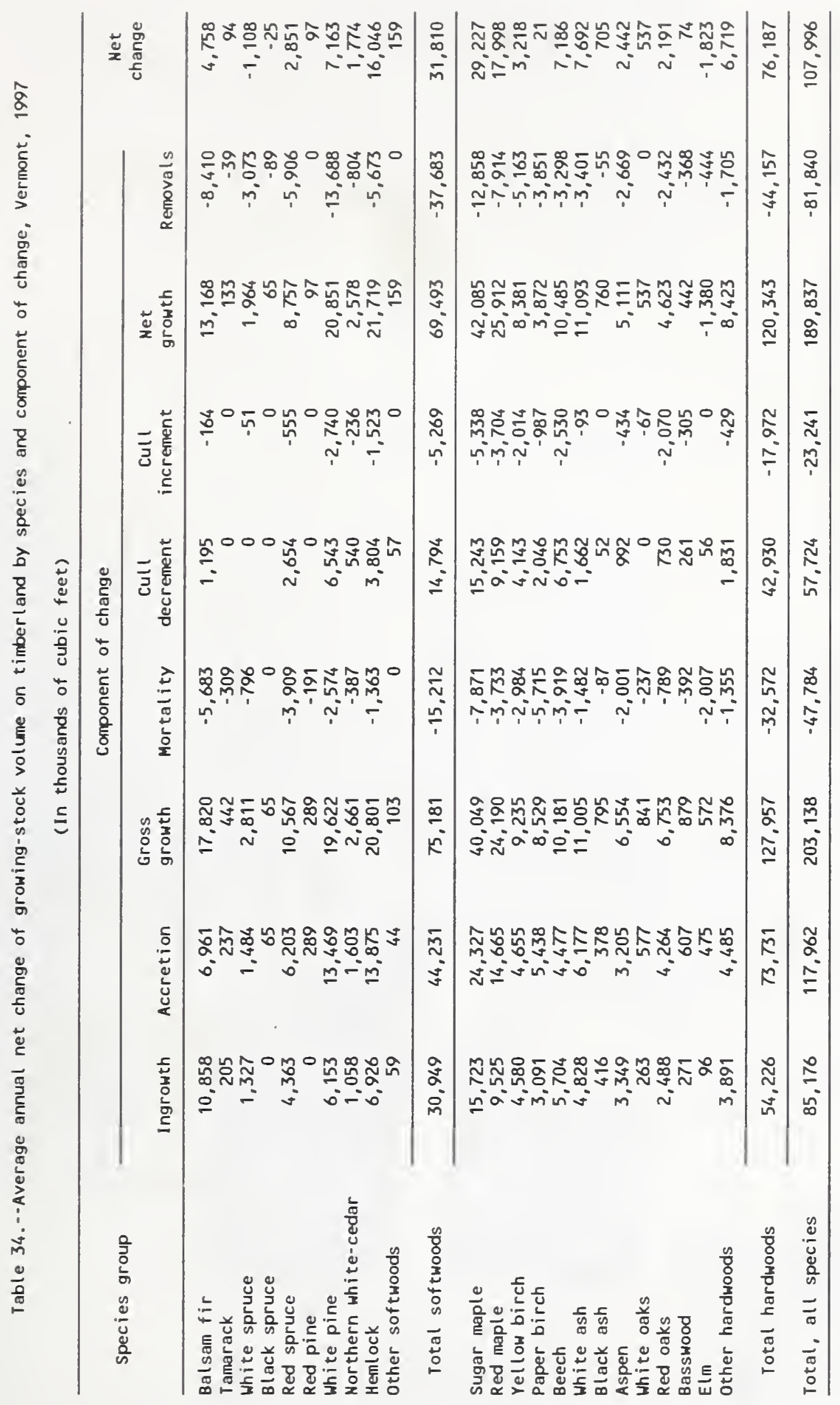




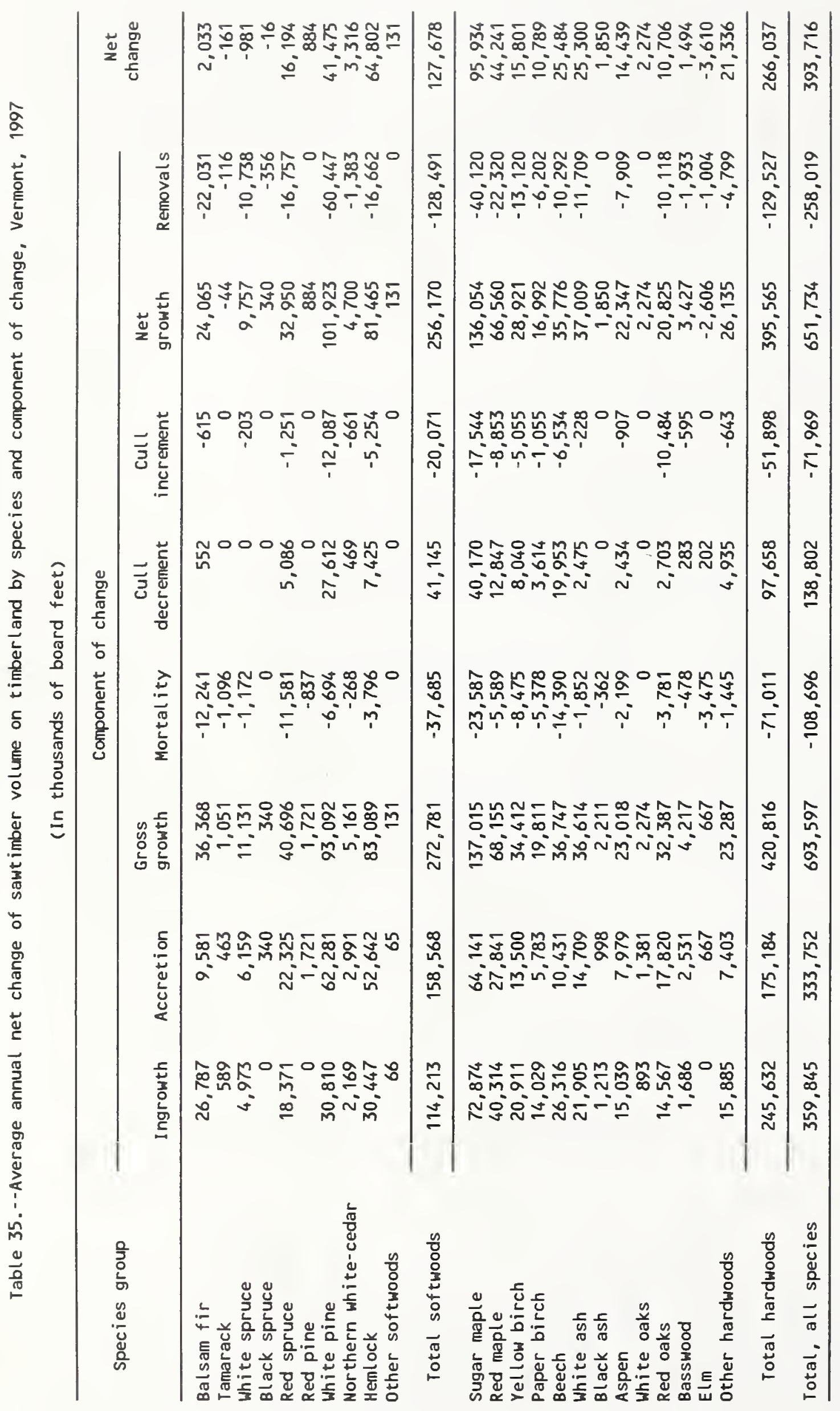




\section{NORTHERN UNIT TABLES}
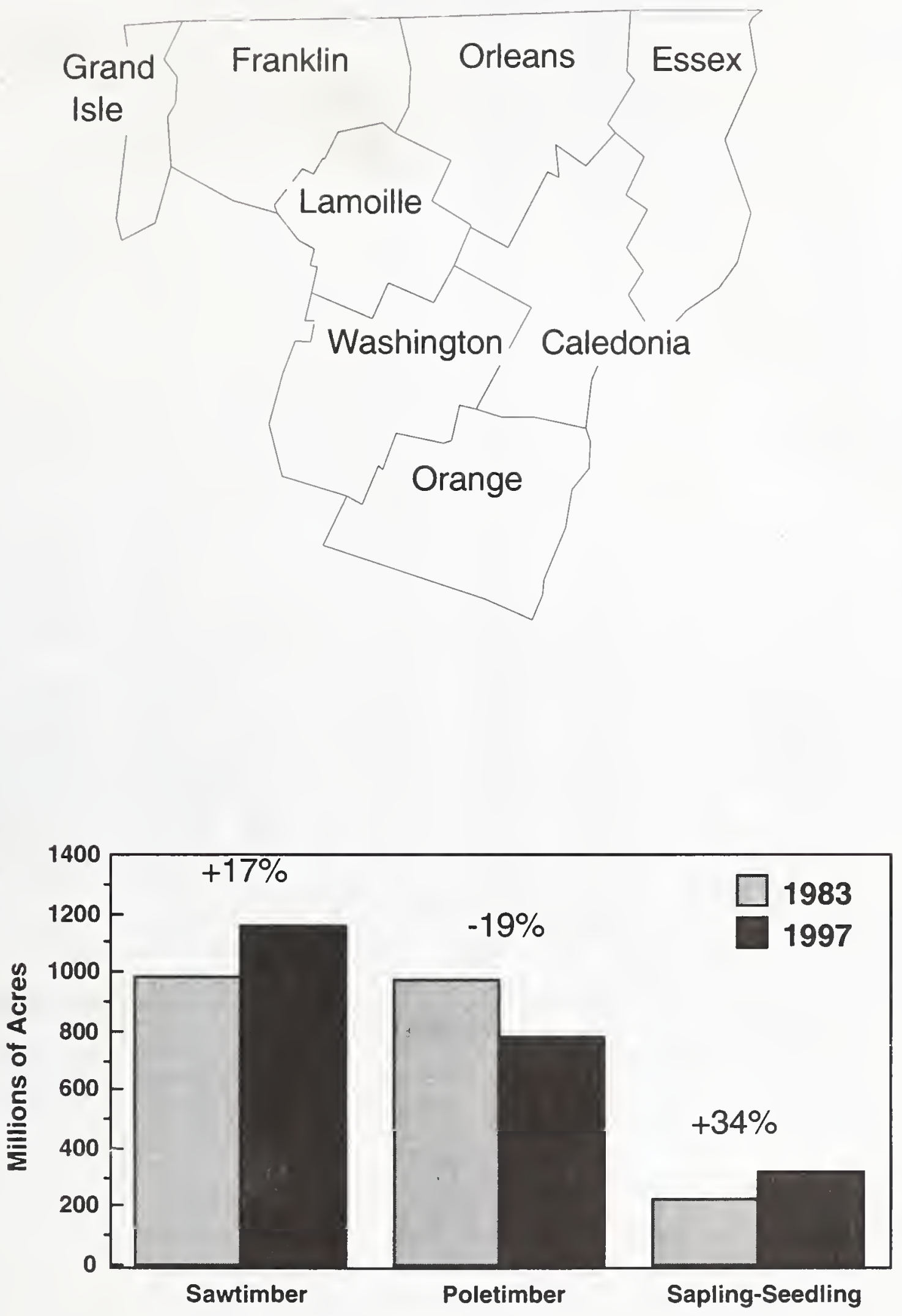

Northern Unit, area of timberland by stand-size class, 1983 and 1997 
Table 36.--Area of timberland by forest type, forest-type group, and stand-size

class, Northern Unit, Vermont, 1983

(In thousands of acres)

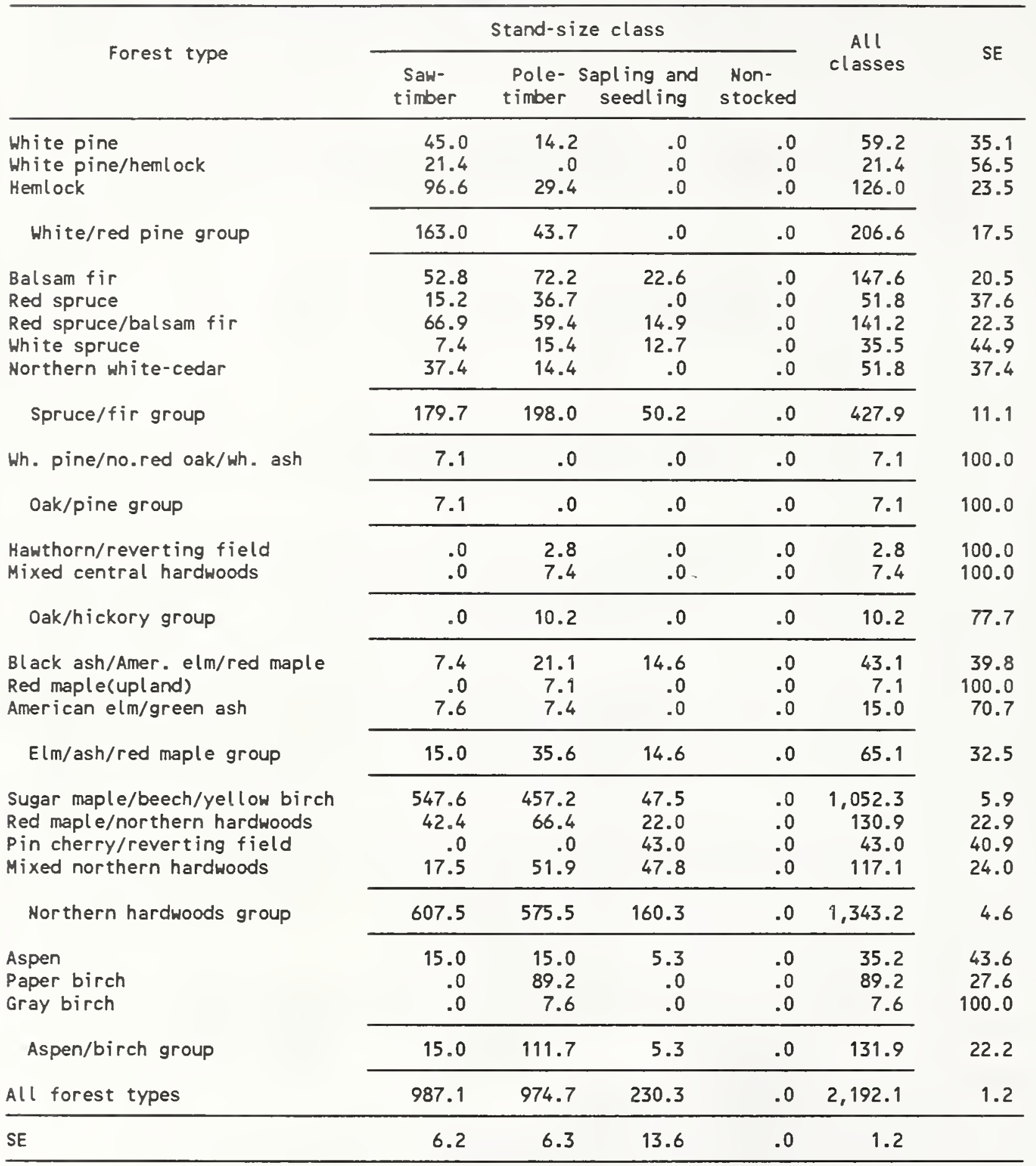


Table 37.--Area of timberland by forest type, forest-type group, and stand-size class, Northern Unit, Vermont, 1997

\begin{tabular}{|c|c|c|c|c|c|c|}
\hline \multirow{2}{*}{ Forest type } & \multicolumn{4}{|c|}{ Stand-size class } & \multirow{2}{*}{$\begin{array}{c}\text { All } \\
\text { classes }\end{array}$} & \multirow{2}{*}{ SE } \\
\hline & $\begin{array}{l}\text { Saw- } \\
\text { timber }\end{array}$ & $\begin{array}{l}\text { Pole- } \\
\text { timber }\end{array}$ & $\begin{array}{l}\text { Sapl ing and } \\
\text { seedl ing }\end{array}$ & $\begin{array}{l}\text { Non- } \\
\text { stocked }\end{array}$ & & \\
\hline Red pine & .0 & .1 & .0 & .0 & .1 & 100.0 \\
\hline White pine & 35.2 & 21.4 & 7.6 & .0 & 64.2 & 28.6 \\
\hline Whit $=$ pine/hemlock & 31.6 & 1.7 & .0 & .0 & 33.3 & 42.2 \\
\hline Heml ock & 135.4 & .6 & .0 & .0 & 135.9 & 19.3 \\
\hline White/red pine group & 202.1 & 23.8 & 7.6 & .0 & 233.6 & 14.3 \\
\hline Balsam fir & 46.8 & 113.8 & 52.0 & .0 & 212.6 & 15.2 \\
\hline Red spruce & 10.9 & 7.9 & .0 & .0 & 18.7 & 51.9 \\
\hline Red spruce/balsam fir & 31.5 & 42.5 & 18.2 & .0 & 92.2 & 23.7 \\
\hline White spruce & 20.1 & 6.5 & .0 & .0 & 26.6 & 47.5 \\
\hline Black spruce & .0 & .0 & 4.8 & .0 & 4.8 & 100.0 \\
\hline Northern white-cedar & 20.4 & 12.6 & .0 & .0 & 33.1 & 41.8 \\
\hline Tamiarack & 6.4 & .0 & .0 & .0 & 6.4 & 100.0 \\
\hline Spruce/fir group & 136.1 & 183.3 & 75.0 & .0 & 394.4 & 10.3 \\
\hline Wh. pine/no.red oak/wh. ash & .0 & 12.4 & .0 & .0 & 12.4 & 70.7 \\
\hline Oak/pine group & .0 & 12.4 & .0 & .0 & 12.4 & 70.7 \\
\hline $\begin{array}{l}\text { Hawthorn/reverting field } \\
\text { Mixed central hardwoods }\end{array}$ & 6.0 & $\begin{array}{r}.0 \\
6.5\end{array}$ & $\begin{array}{r}1.1 \\
.0\end{array}$ & $\begin{array}{l}.0 \\
.0\end{array}$ & $\begin{array}{r}1.1 \\
12.9\end{array}$ & $\begin{array}{r}100.0 \\
70.7\end{array}$ \\
\hline Oak/hickory group & 6.4 & 6.5 & 1.1 & .0 & 14.0 & 65.6 \\
\hline $\begin{array}{l}\text { Black ash/Amer. elm/red maple } \\
\text { Red maple(upland) }\end{array}$ & $\begin{array}{r}3.2 \\
.0\end{array}$ & $\begin{array}{r}12.5 \\
5.0\end{array}$ & $\begin{array}{r}11.9 \\
.0\end{array}$ & $\begin{array}{l}.0 \\
.0\end{array}$ & $\begin{array}{r}27.6 \\
5.0\end{array}$ & $\begin{array}{r}45.8 \\
100.0\end{array}$ \\
\hline Elm/ash/red maple group & 3.2 & 17.5 & 11.9 & .0 & 32.6 & 40.8 \\
\hline $\begin{array}{l}\text { Sugar maple/beech/yellow birch } \\
\text { Black Cherry } \\
\text { Red maple/northern hardwoods } \\
\text { Pin cherry/reverting field } \\
\text { Mixed northern hardwoods }\end{array}$ & $\begin{array}{r}672.8 \\
.0 \\
75.6 \\
.0 \\
18.5 \\
\end{array}$ & $\begin{array}{r}287.0 \\
2.2 \\
123.9 \\
6.8 \\
57.4 \\
\end{array}$ & $\begin{array}{r}63.9 \\
.0 \\
27.2 \\
64.2 \\
22.3\end{array}$ & $\begin{array}{r}.0 \\
.0 \\
.0 \\
2.6 \\
.0\end{array}$ & $\begin{array}{r}1.023 .8 \\
2.2 \\
226.7 \\
73.6 \\
98.2 \\
\end{array}$ & $\begin{array}{r}5.7 \\
100.0 \\
15.7 \\
26.4 \\
23.4\end{array}$ \\
\hline Northern hardwoods group & 766.9 & 477.4 & 177.5 & 2.6 & $1,424.5$ & 4.0 \\
\hline $\begin{array}{l}\text { Aspen } \\
\text { Paper birch } \\
\text { Gray birch }\end{array}$ & $\begin{array}{r}25.6 \\
17.8 \\
.0\end{array}$ & $\begin{array}{r}17.0 \\
43.6 \\
3.3\end{array}$ & $\begin{array}{r}32.1 \\
13.0 \\
1.8\end{array}$ & $\begin{array}{l}.0 \\
.0 \\
.0\end{array}$ & $\begin{array}{r}74.7 \\
74.4 \\
5.0\end{array}$ & $\begin{array}{l}26.8 \\
27.9 \\
57.1\end{array}$ \\
\hline Aspen/birch group & 43.5 & 63.8 & 46.9 & .0 & 154.2 & 18.7 \\
\hline All forest types & $1,158.2$ & 784.7 & 320.1 & 2.6 & $2,265.6$ & 1.4 \\
\hline SE & 4.8 & 7.1 & 11.8 & 100.0 & 1.4 & \\
\hline
\end{tabular}




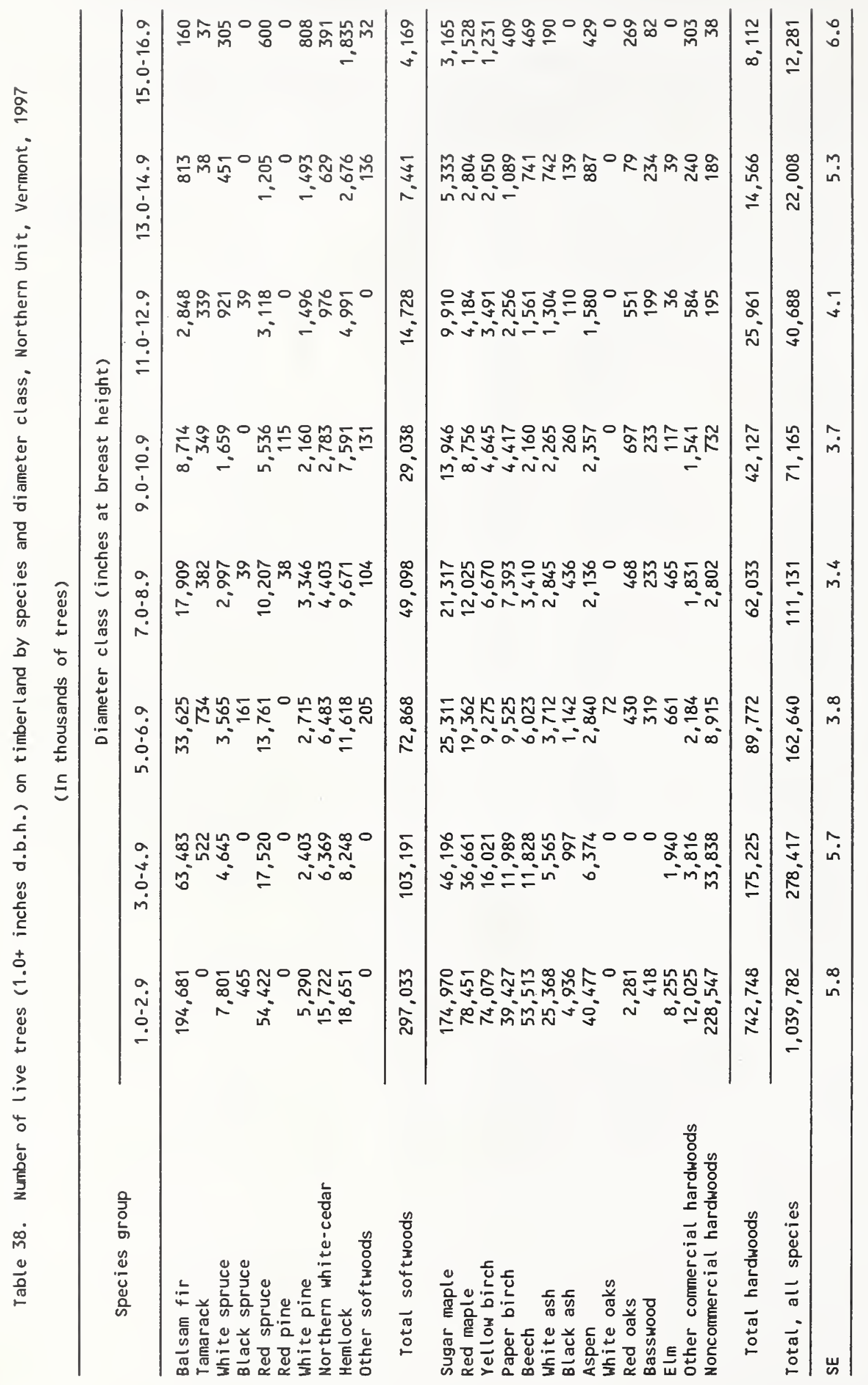




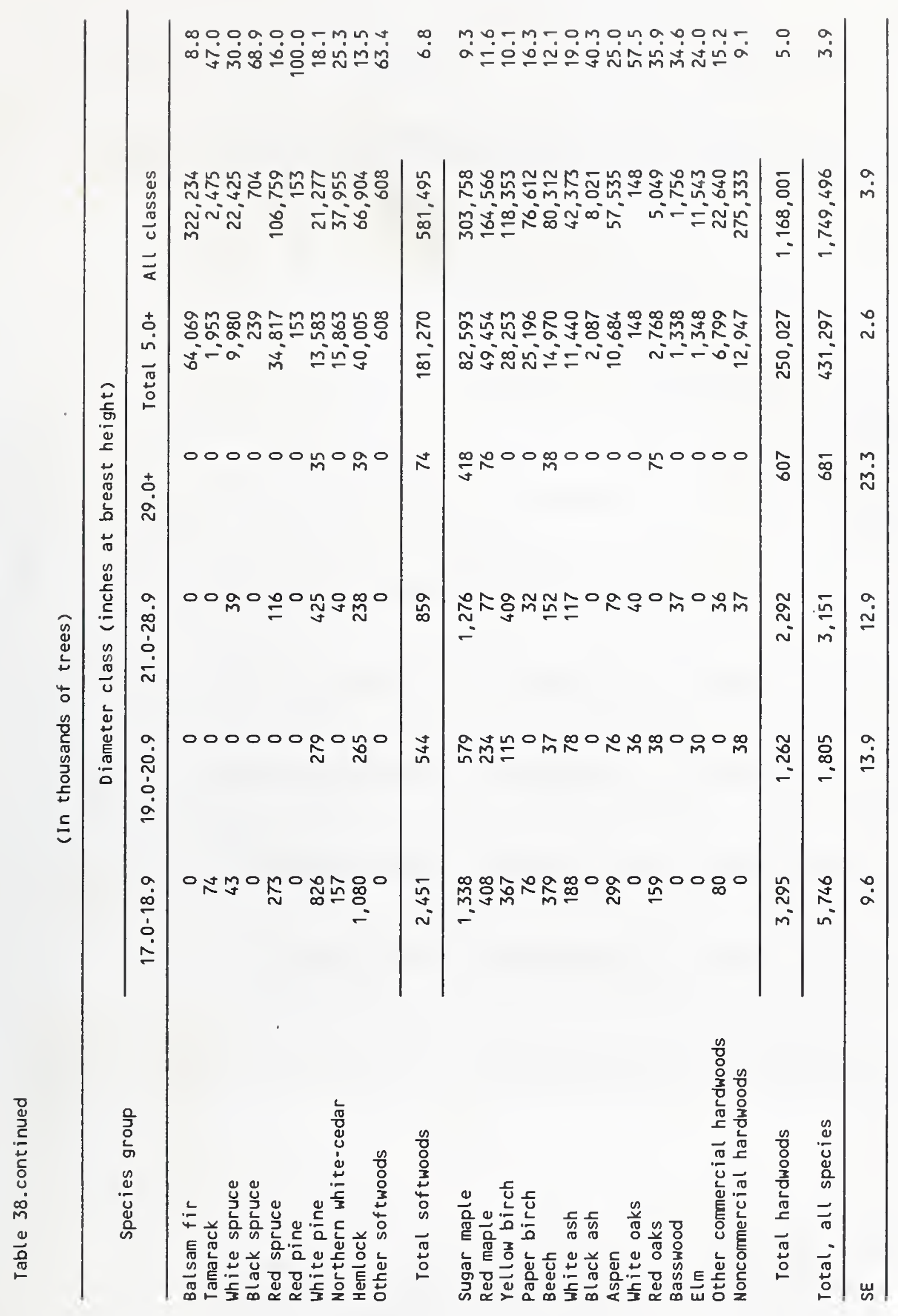




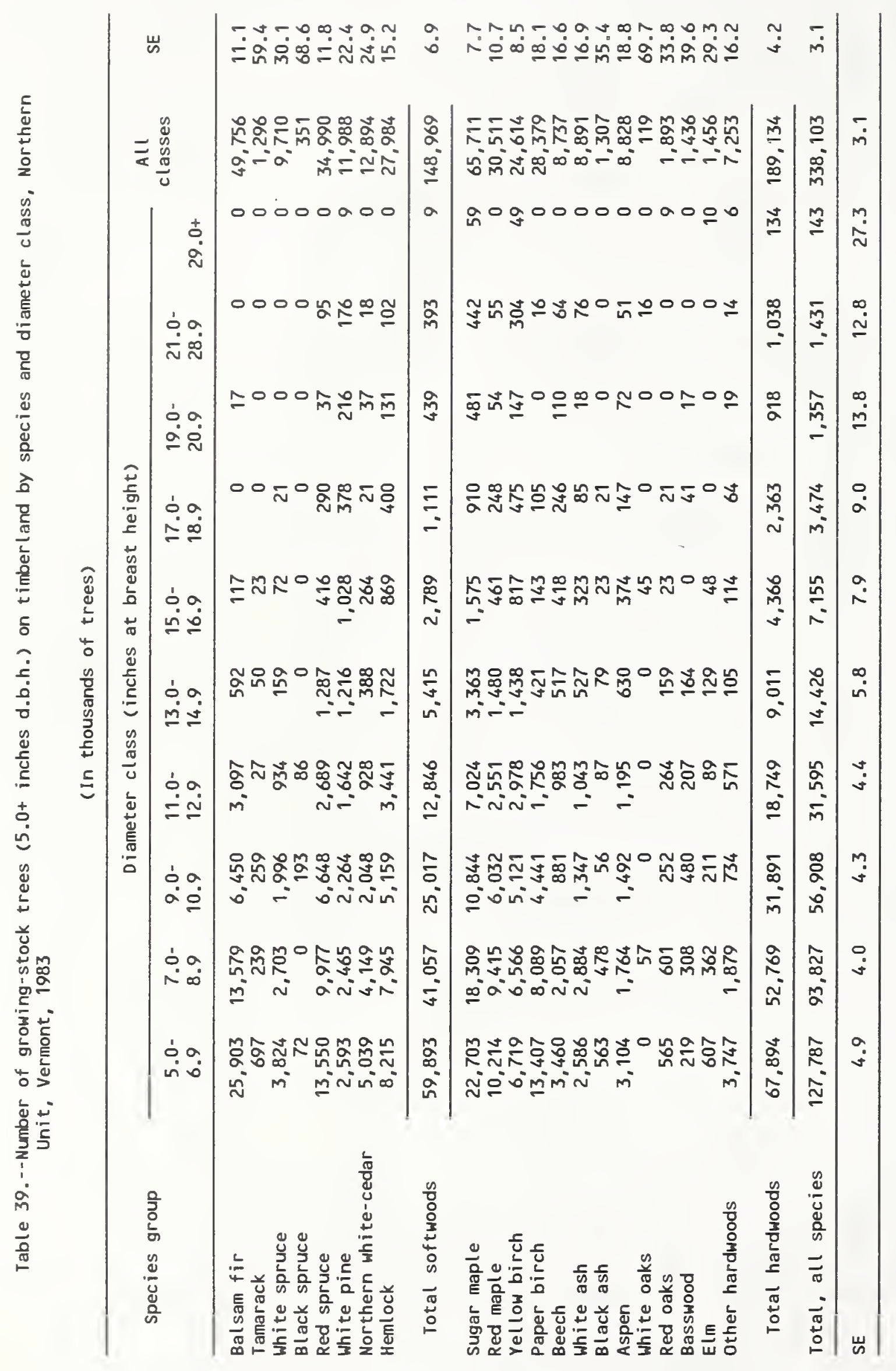




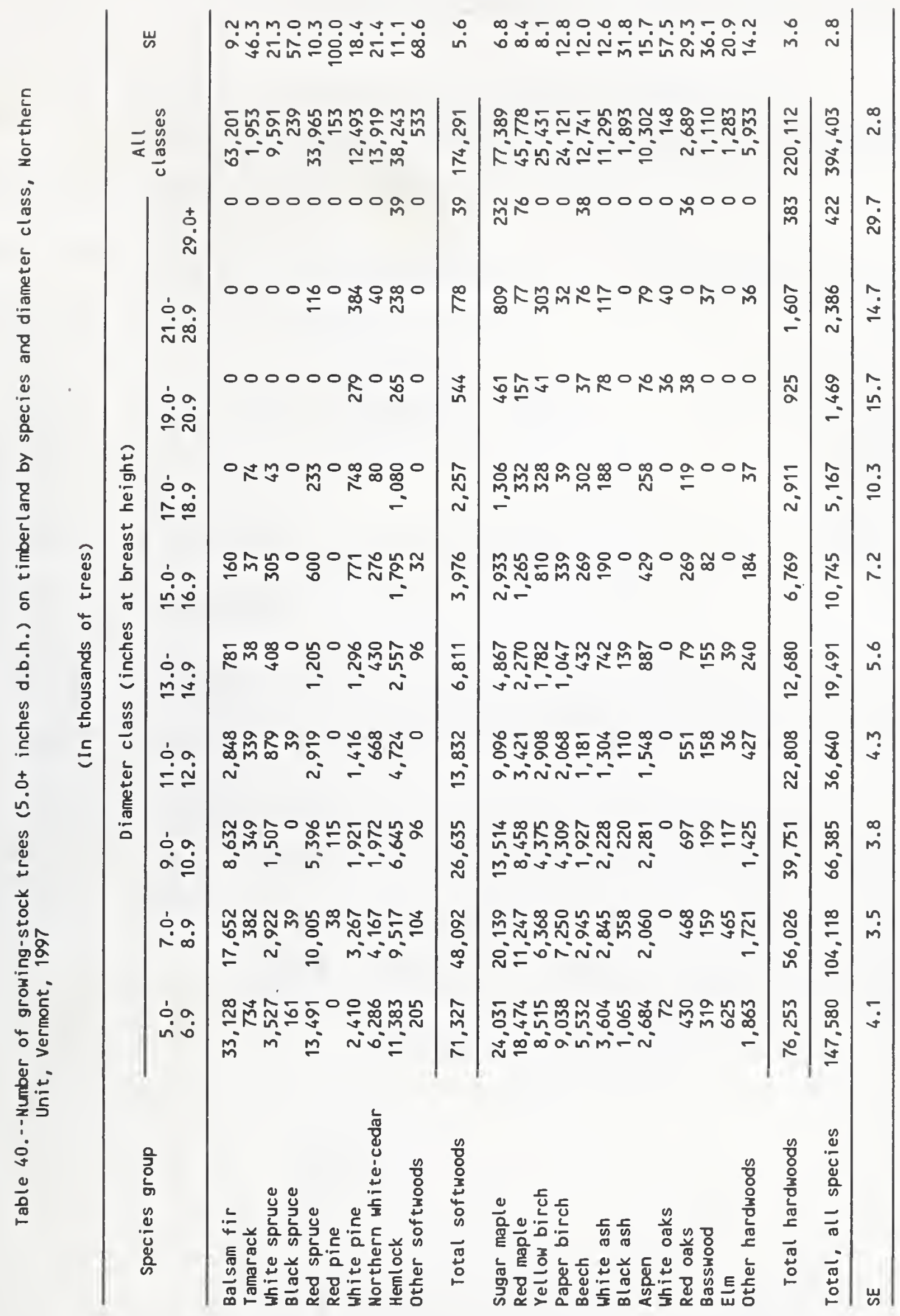




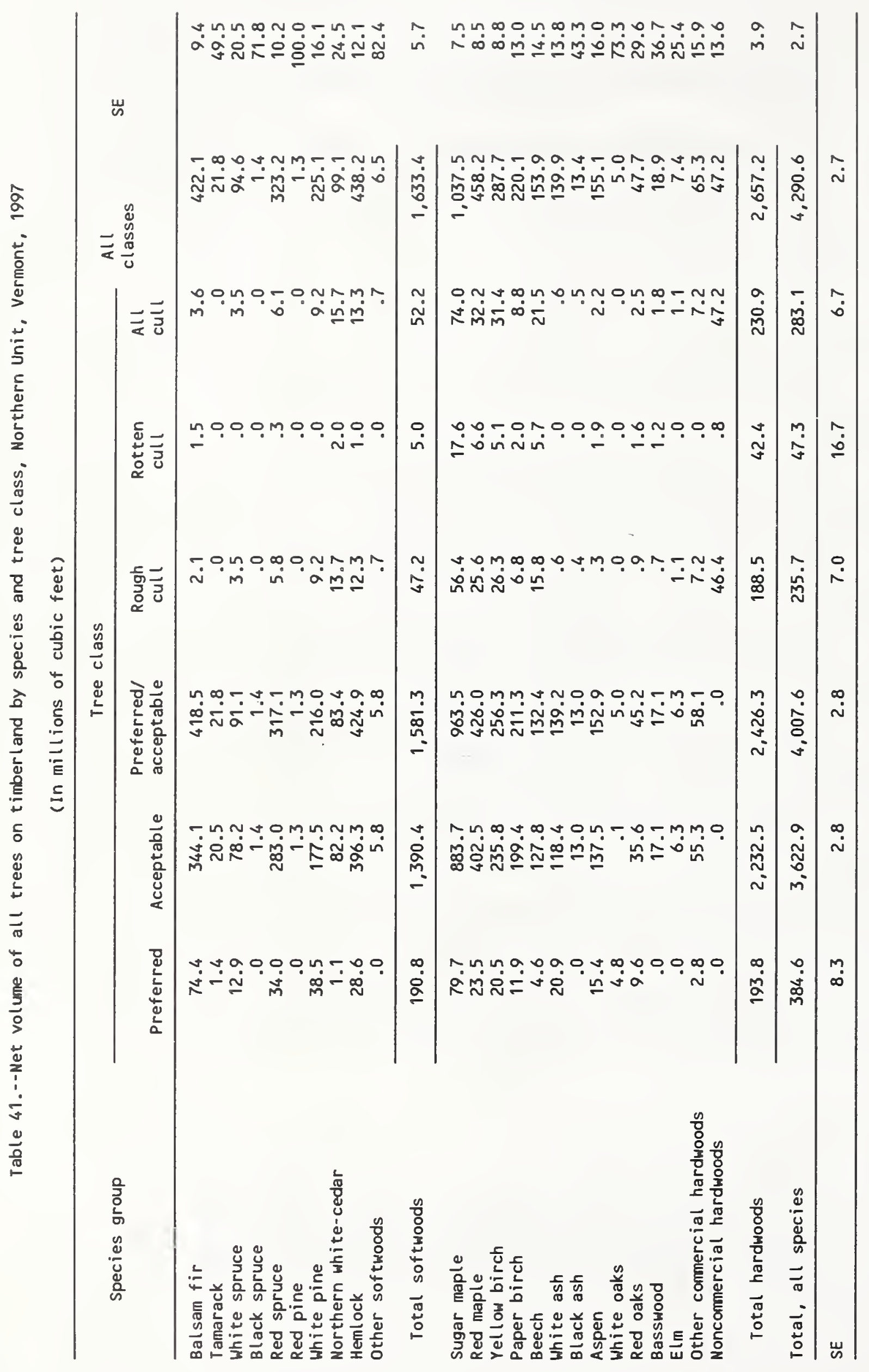


Volume of all live trees on timberland, for selected species and percent change, Northern Unit of Vermont, 1983 and 1997

(Volume increased by 15.5 percent for all species)

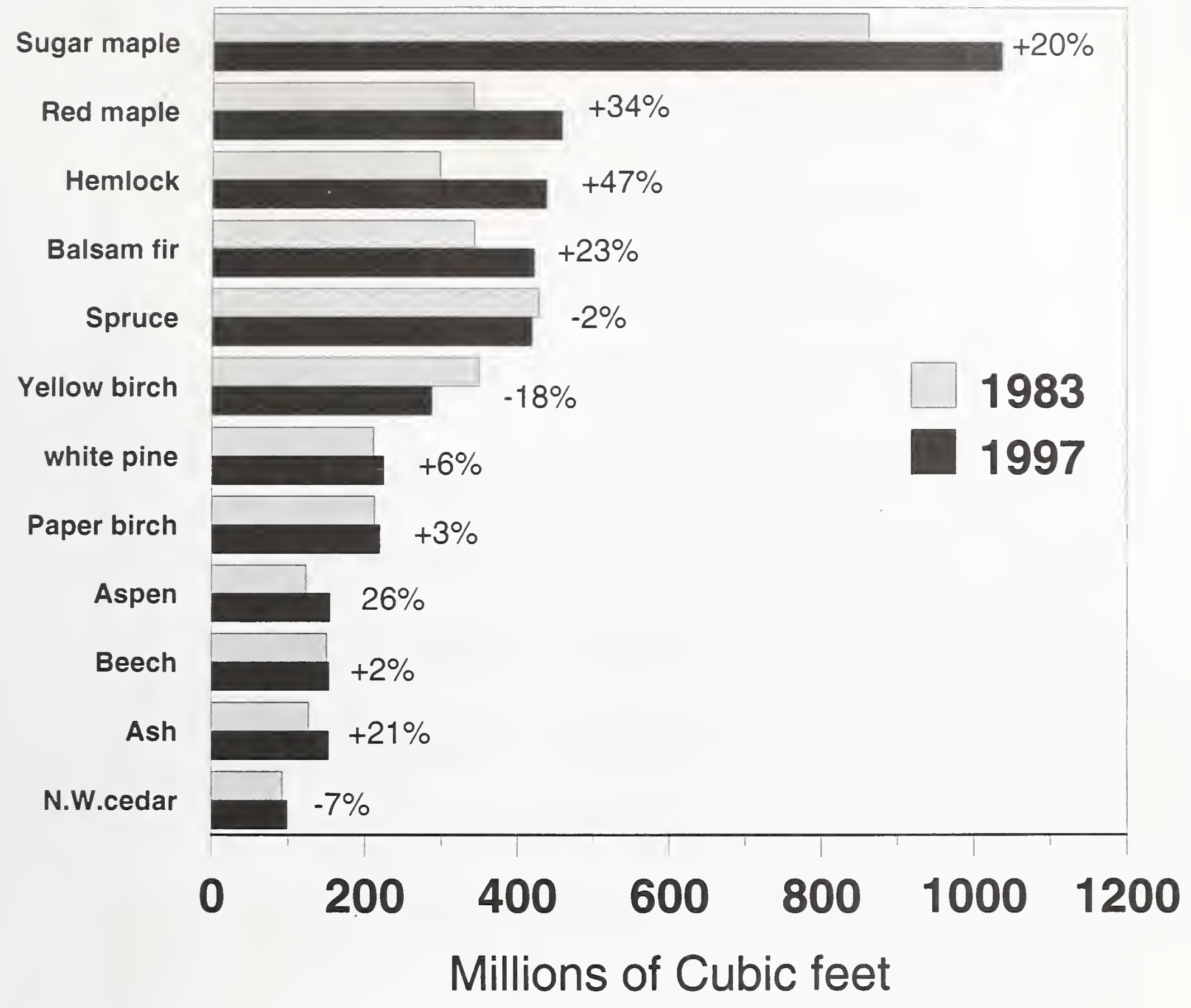




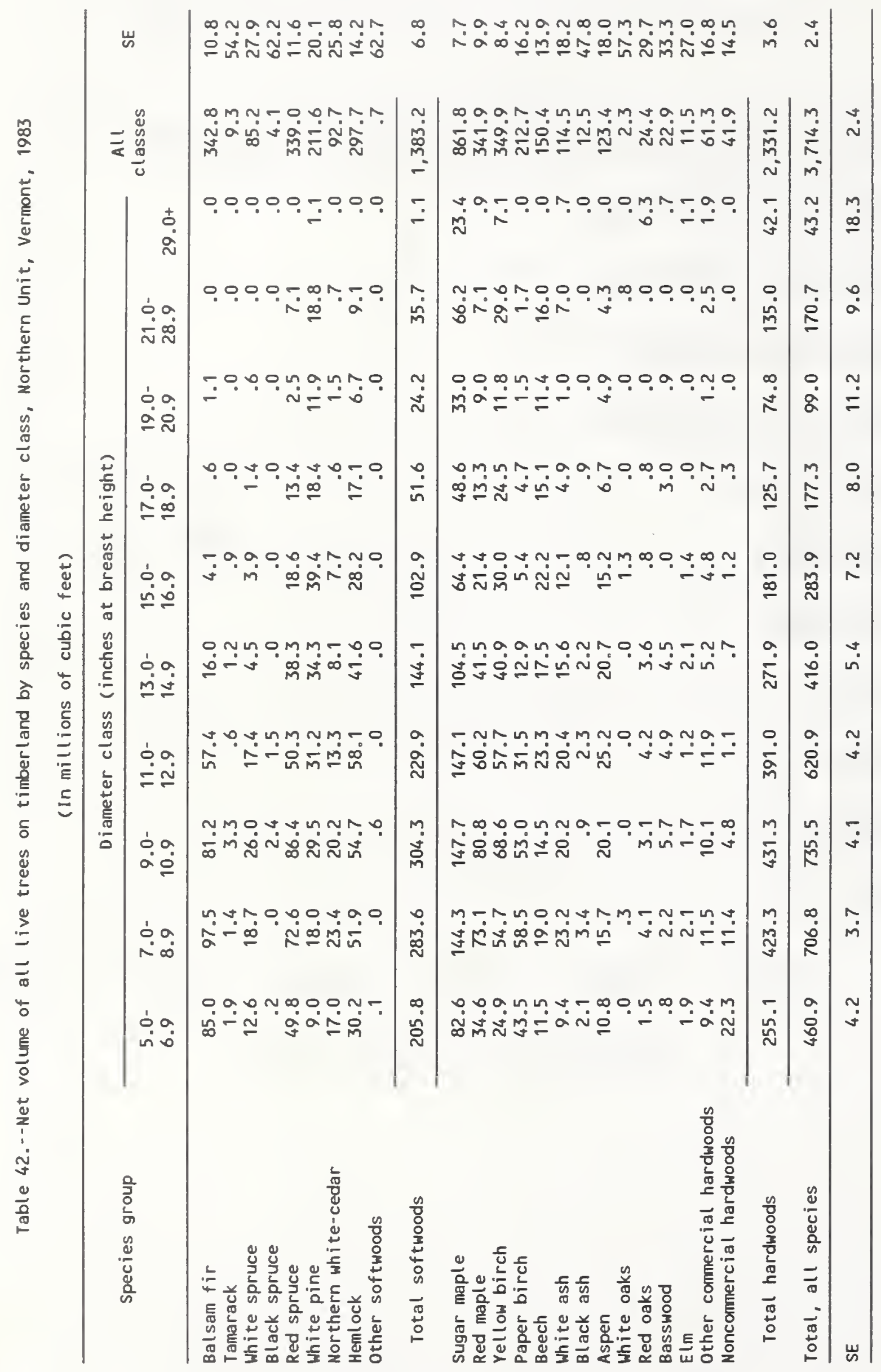




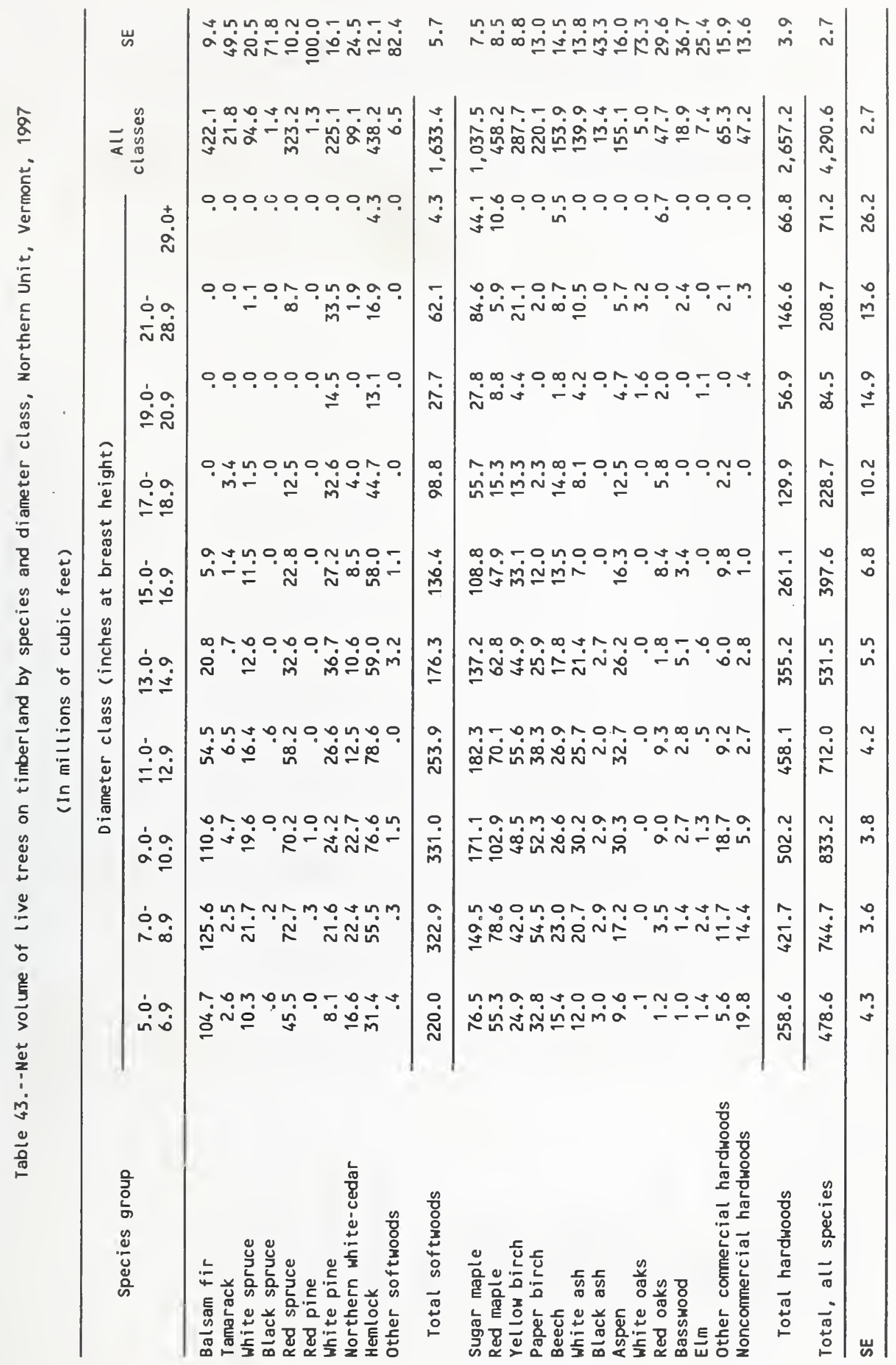




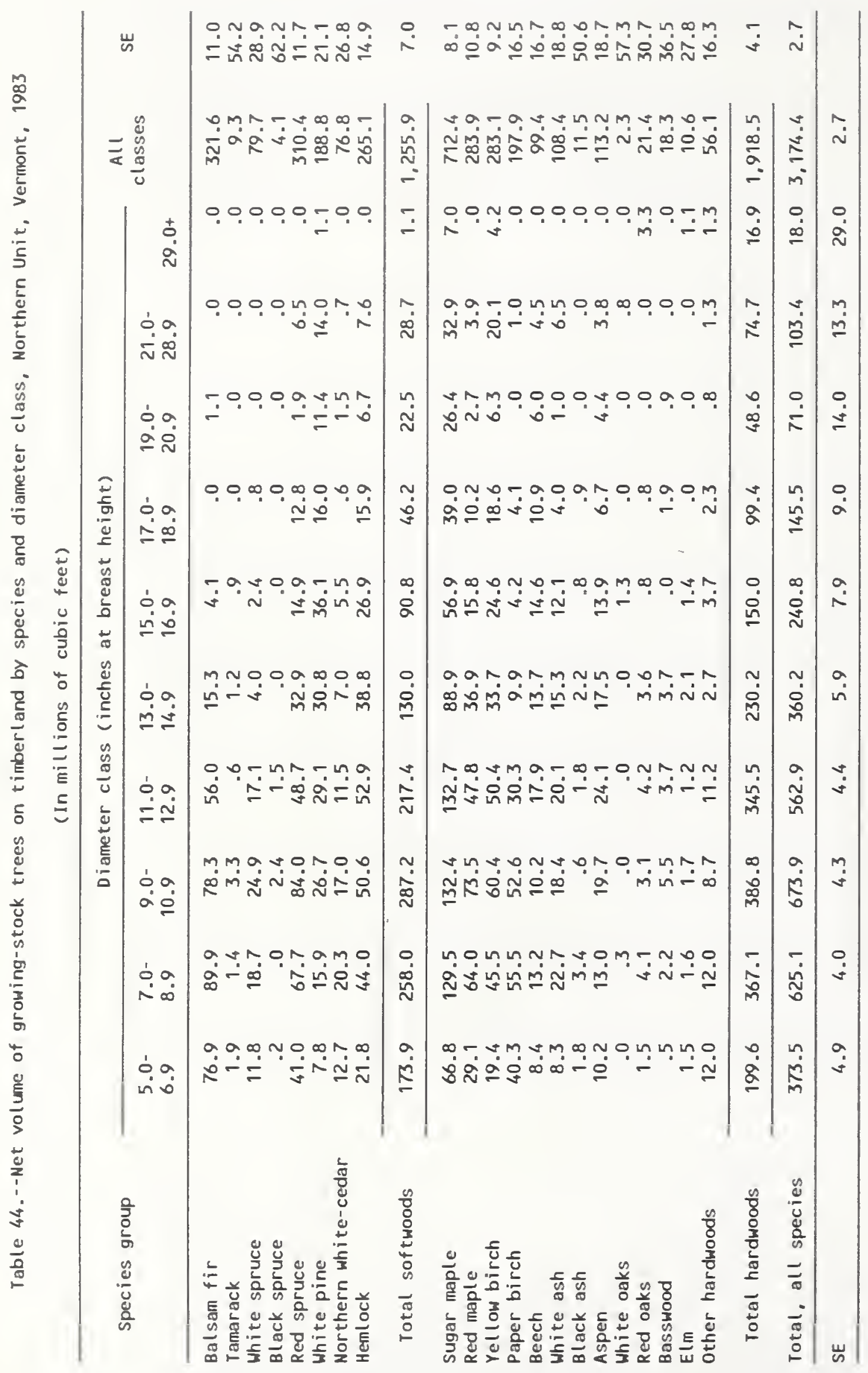




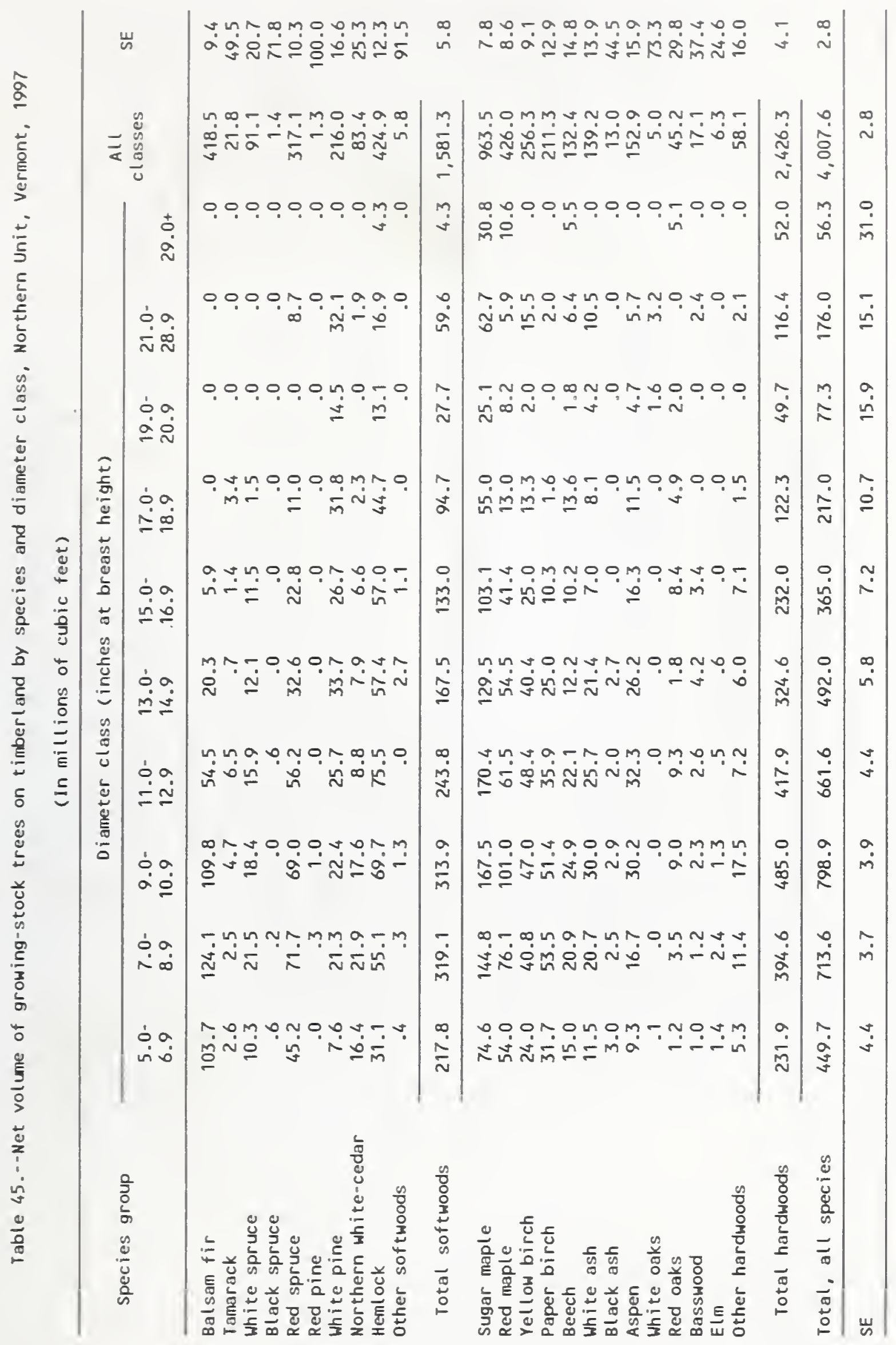


Table 46. - Net volume of growing-stock trees on timberland by species and stand-size class, Northern Unit, Vermont, 1983

(In millions of cubic feet)

\begin{tabular}{|c|c|c|c|c|c|c|}
\hline \multirow{2}{*}{ Species group } & \multicolumn{4}{|c|}{ Stand-size class } & \multirow{2}{*}{$\begin{array}{c}\text { All } \\
\text { classes }\end{array}$} & \multirow{2}{*}{ SE } \\
\hline & $\begin{array}{l}\text { Saw- } \\
\text { timber }\end{array}$ & $\begin{array}{l}\text { Pole- } \\
\text { timber }\end{array}$ & $\begin{array}{l}\text { Sapling and } \\
\text { seedl ing }\end{array}$ & $\begin{array}{l}\text { Non- } \\
\text { stocked }\end{array}$ & & \\
\hline Balsam fir & 152.3 & 162.3 & 6.9 & .0 & 321.6 & 11.0 \\
\hline Tamarack & 1.8 & 7.5 & .0 & .0 & 9.3 & 54.2 \\
\hline White spruce & 36.9 & 37.5 & 5.3 & .0 & 79.7 & 28.9 \\
\hline Black spruce & 2.3 & 1.8 & .0 & .0 & 4.1 & 62.2 \\
\hline Red spruce & 165.1 & 137.5 & 7.8 & .0 & 310.4 & 11.7 \\
\hline White pine & 143.9 & 34.1 & 10.8 & .0 & 188.8 & 21.1 \\
\hline Northern white-cedar & 47.4 & 25.7 & 3.7 & .0 & 76.8 & 26.8 \\
\hline Hemlock & 215.5 & 49.2 & .4 & .0 & 265.1 & 14.9 \\
\hline Total softwoods & 765.2 & 455.6 & 35.0 & .0 & $1,255.9$ & 7.0 \\
\hline Sugar maple & 443.9 & 260.8 & 7.7 & .0 & 712.4 & 8.1 \\
\hline Red maple & 125.6 & 156.9 & 1.4 & .0 & 283.9 & 10.8 \\
\hline Yellow birch & 165.0 & 116.6 & 1.5 & .0 & 283.1 & 9.2 \\
\hline Paper birch & 40.1 & 155.9 & 2.0 & .0 & 197.9 & 16.5 \\
\hline Beech & 73.3 & 25.6 & .5 & .0 & 99.4 & 16.7 \\
\hline White ash & 37.8 & 69.9 & .7 & .0 & 108.4 & 18.8 \\
\hline Black ash & 7.5 & 3.5 & .4 & .0 & 11.5 & 50.6 \\
\hline Aspen & 57.7 & 51.4 & 4.1 & .0 & 113.2 & 18.7 \\
\hline White oaks & 1.7 & .6 & .0 & .0 & 2.3 & 57.3 \\
\hline Red oaks & 7.8 & 13.6 & .0 & .0 & 21.4 & 30.7 \\
\hline Basswood & 5.3 & 12.1 & .9 & .0 & 18.3 & 36.5 \\
\hline Elm & 5.1 & 5.5 & .0 & .0 & 10.6 & 27.8 \\
\hline Other hardwoods & 24.1 & 31.1 & .9 & .0 & 56.1 & 16.3 \\
\hline Total hardwoods & 995.0 & 903.6 & 20.0 & .0 & $1,918.5$ & 4.1 \\
\hline Total, all species & $1,760.2$ & $1,359.2$ & 55.0 & .0 & $3,174.4$ & 2.7 \\
\hline SE & 6.9 & 7.4 & 22.1 & .0 & 2.7 & \\
\hline
\end{tabular}


Table 47.--Net volume of growing-stock trees on timberland by species and stand-size class, Northern Unit, Vermont, 1997

(In millions of cubic feet)

\begin{tabular}{|c|c|c|c|c|c|c|}
\hline \multirow{2}{*}{ Species group } & \multicolumn{4}{|c|}{ Stand-size class } & \multirow{2}{*}{$\begin{array}{c}\text { All } \\
\text { classes }\end{array}$} & \multirow{2}{*}{ SE } \\
\hline & $\begin{array}{l}\text { Saw- } \\
\text { timber }\end{array}$ & $\begin{array}{l}\text { Pole- } \\
\text { timber }\end{array}$ & $\begin{array}{l}\text { Sapl ing and } \\
\text { seedl ing }\end{array}$ & $\begin{array}{l}\text { Non- } \\
\text { stocked }\end{array}$ & & \\
\hline Balsam fir & 166.4 & 222.3 & 29.8 & .0 & 418.5 & 9.4 \\
\hline Tamarack & 19.6 & 1.8 & .5 & .0 & 21.8 & 49.5 \\
\hline White spruce & 57.4 & 27.7 & 6.0 & .0 & 91.1 & 20.7 \\
\hline Black spruce & .0 & .2 & 1.2 & .0 & 1.4 & 71.8 \\
\hline Red spruce & 184.6 & 122.3 & 10.2 & .0 & 317.1 & 10.3 \\
\hline Red pine & .0 & 1.3 & .0 & .0 & 1.3 & 100.0 \\
\hline White pine & 145.1 & 64.7 & 6.2 & .0 & 216.0 & 16.6 \\
\hline Northern white-cedar & 47.9 & 31.6 & 3.8 & .0 & 83.4 & 25.3 \\
\hline Heml ock & 387.7 & 34.3 & 2.8 & .0 & 424.9 & 12.3 \\
\hline Other sof twoods & 5.3 & .0 & .5 & .0 & 5.8 & 91.5 \\
\hline Total softwoods & $1,014.2$ & 506.2 & 60.9 & .0 & $1,581.3$ & 5.8 \\
\hline Sugar maple & 730.6 & 219.6 & 13.3 & .0 & 963.5 & 7.8 \\
\hline Red maple & 234.1 & 184.2 & 7.7 & .0 & 426.0 & 8.6 \\
\hline Yellow birch & 184.8 & 70.0 & 1.5 & .0 & 256.3 & 9.1 \\
\hline Paper birch & 85.2 & 121.8 & 4.4 & .0 & 211.3 & 12.9 \\
\hline Beech & 101.6 & 27.1 & 3.8 & .0 & 132.4 & 14.8 \\
\hline White ash & 86.8 & 49.0 & 3.3 & .1 & 139.2 & 13.9 \\
\hline Black ash & 2.5 & 5.8 & 4.6 & .0 & 13.0 & 44.5 \\
\hline Aspen & 106.3 & 43.7 & 2.9 & .0 & 152.9 & 15.9 \\
\hline White oaks & 3.2 & 1.7 & .0 & .0 & 5.0 & 73.3 \\
\hline Red oaks & 30.7 & 14.4 & .0 & .0 & 45.2 & 29.8 \\
\hline Basswood & 15.9 & 1.2 & .0 & .0 & 17.1 & 37.4 \\
\hline Elm & 3.5 & 1.9 & .9 & .0 & 6.3 & 24.6 \\
\hline Other hardwoods & 23.7 & 30.5 & 3.9 & .0 & 58.1 & 16.0 \\
\hline Total hardwoods & $1,608.8$ & 771.1 & 46.3 & .1 & $2,426.3$ & 4.1 \\
\hline Total, all species & $2,623.0$ & $1,277.3$ & 107.2 & .1 & $4,007.6$ & 2.8 \\
\hline SE & 5.4 & 8.0 & 18.0 & 100.0 & 2.8 & \\
\hline
\end{tabular}


Table 48.-- Net volume of growing-stock trees on timberland by forest type and stand-size class, Northern Unit, Vermont, 1997

(In millions of cubic feet)

\begin{tabular}{|c|c|c|c|c|c|c|}
\hline \multirow{2}{*}{ Forest type } & \multicolumn{4}{|c|}{ Stand-size class } & \multirow{2}{*}{$\begin{array}{l}\text { All } \\
\text { classes }\end{array}$} & \multirow{2}{*}{ SE } \\
\hline & $\begin{array}{l}\text { Saw- } \\
\text { timber }\end{array}$ & $\begin{array}{l}\text { Pole- } \\
\text { timber }\end{array}$ & $\begin{array}{l}\text { Sapling and } \\
\text { seedling }\end{array}$ & $\begin{array}{l}\text { Non- } \\
\text { stocked }\end{array}$ & & \\
\hline Red pine & .0 & 1.3 & .0 & .0 & 1.3 & 100.0 \\
\hline White pine & 96.7 & 28.7 & .1 & .0 & 125.5 & 36.1 \\
\hline White pine/hemlock & 59.7 & 3.2 & .0 & .0 & 62.9 & 43.4 \\
\hline Hemlock & 367.6 & .2 & .0 & .0 & 367.8 & 20.1 \\
\hline White/red pine group & 524.1 & 33.4 & .1 & .0 & 557.5 & 15.7 \\
\hline Balsam fir & 69.1 & 214.5 & 15.1 & .0 & 298.6 & 18.8 \\
\hline Red spruce & 24.5 & 15.8 & .0 & .0 & 40.2 & 51.6 \\
\hline Red spruce/balsam fir & 69.7 & 93.1 & 9.4 & .0 & 172.2 & 27.1 \\
\hline White spruce & 59.8 & 6.3 & .0 & .0 & 66.0 & 52.6 \\
\hline Black spruce & .0 & .0 & 1.8 & .0 & 1.8 & 100.0 \\
\hline Northern white-cedar & 62.5 & 29.6 & .0 & .0 & 92.0 & 42.3 \\
\hline Tamarack & 19.0 & .0 & .0 & .0 & 19.0 & 100.0 \\
\hline Spruce/fir group & 304.4 & 359.2 & 26.2 & .0 & 689.8 & 12.4 \\
\hline Wh. pine/no.red oak/wh. ash & .0 & 29.8 & .0 & .0 & 29.8 & 72.8 \\
\hline Oak/pine group & .0 & 29.8 & .0 & .0 & 29.8 & 72.8 \\
\hline $\begin{array}{l}\text { Hawthorn/reverting field } \\
\text { Mixed central hardwoods }\end{array}$ & 13.0 & .0 & $\begin{array}{r}1.8 \\
.0\end{array}$ & $\begin{array}{l}.0 \\
.0\end{array}$ & $\begin{array}{r}1.8 \\
23.2\end{array}$ & $\begin{array}{r}100.0 \\
71.8\end{array}$ \\
\hline Oak/hickory group & 13.7 & 9.5 & 1.8 & .0 & 25.0 & 67.1 \\
\hline Black ash/Amer. elm/red maple & 8.0 & 18.2 & 7.4 & .0 & 33.6 & 49.4 \\
\hline Red maple(upland) & .0 & 9.9 & .0 & .0 & 9.9 & 100.0 \\
\hline Elm/ash/red maple group & 8.0 & 28.1 & 7.4 & .0 & 43.5 & 43.8 \\
\hline Sugar maple/beech/yellow birch & $1,417.3$ & 430.6 & 21.0 & .0 & $1,869.0$ & 6.8 \\
\hline Black Cherry & .0 & 1.0 & .0 & .0 & 1.0 & 100.0 \\
\hline Red maple/northern hardwoods & 180.8 & 177.8 & 20.1 & .0 & 378.7 & 17.2 \\
\hline Pin cherry/reverting field & .0 & 5.7 & 13.4 & .1 & 19.1 & 48.3 \\
\hline Mixed northern hardwoods & 52.0 & 96.2 & 9.7 & .0 & 157.9 & 28.3 \\
\hline Northern hardwoods group & $1,650.1$ & 711.3 & 64.2 & .1 & $2,425.7$ & 5.3 \\
\hline Aspen & 74.1 & 24.6 & 5.8 & .0 & 104.6 & 37.2 \\
\hline Paper birch & 48.5 & 81.3 & 1.7 & .0 & 131.5 & 32.8 \\
\hline Gray birch & .0 & .1 & .0 & .0 & .1 & 76.7 \\
\hline Aspen/birch group & 122.6 & 106.1 & 7.5 & .0 & 236.2 & 24.6 \\
\hline All forest types & $2,623.0$ & $1,277.3$ & 107.2 & .1 & $4,007.6$ & 2.8 \\
\hline SE & 5.4 & 8.0 & 18.0 & 100.0 & 2.8 & \\
\hline
\end{tabular}


Percent of growing-stock volume by forest-type group Northern Unit of Vermont, 1997

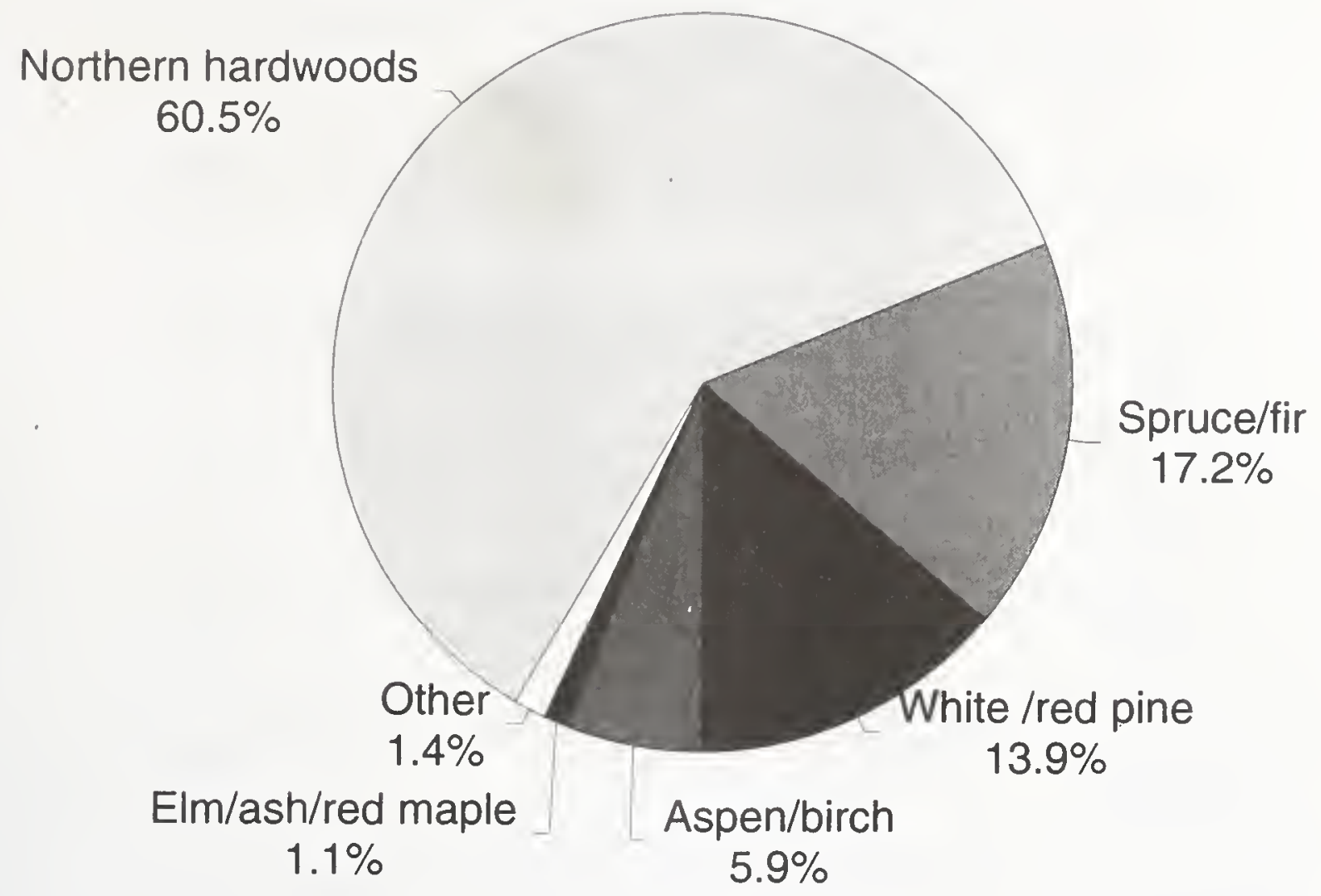




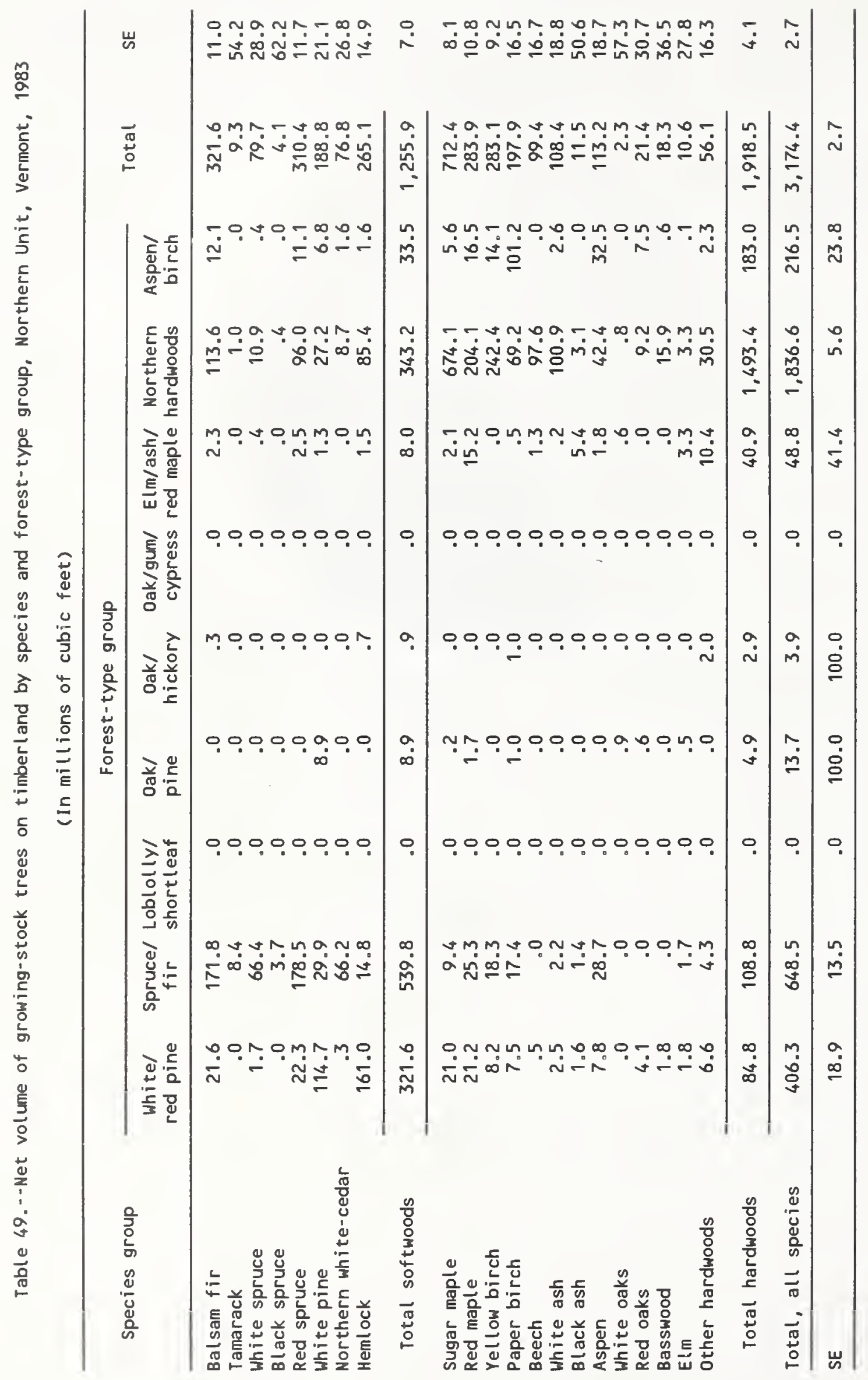




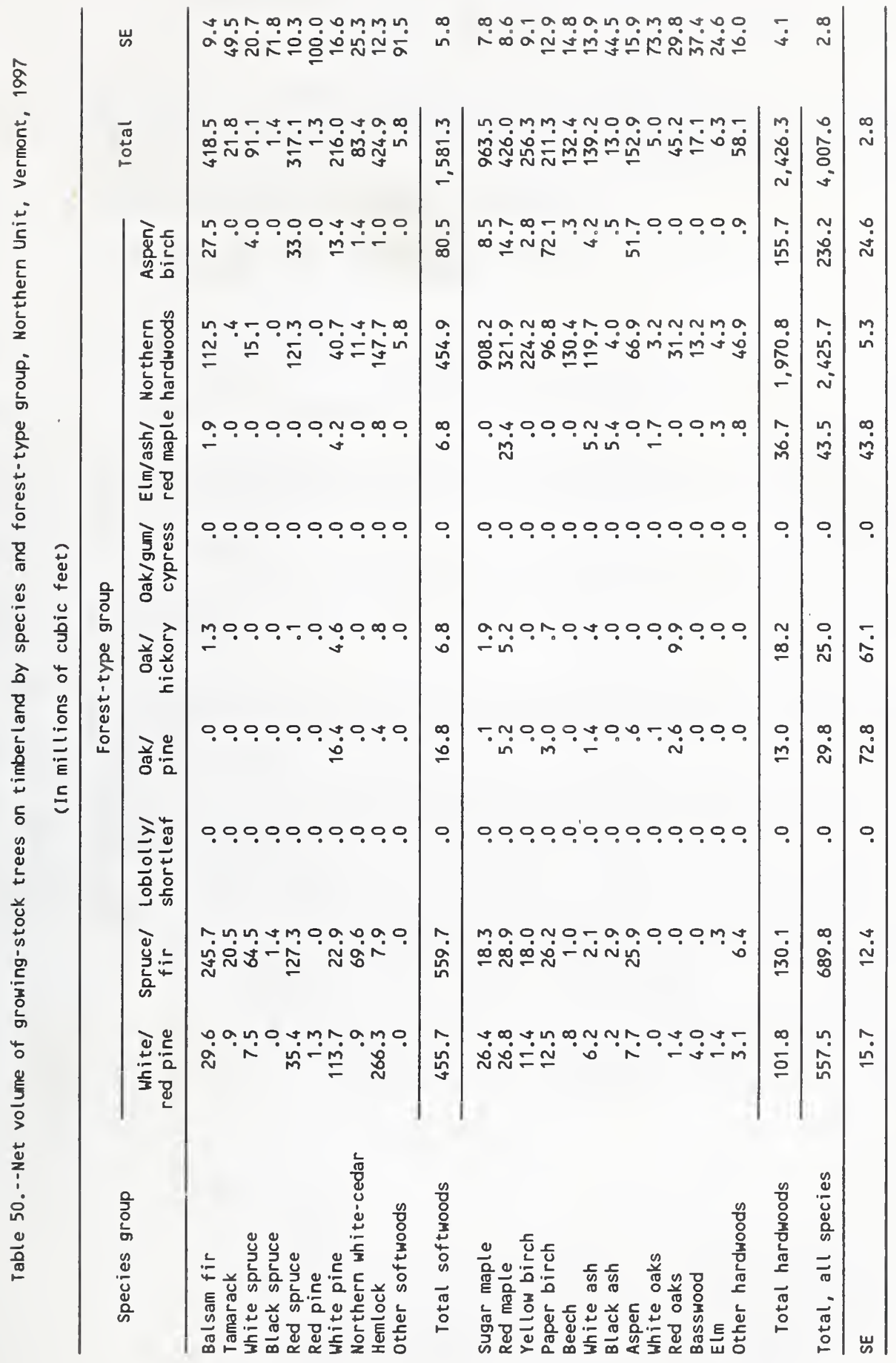




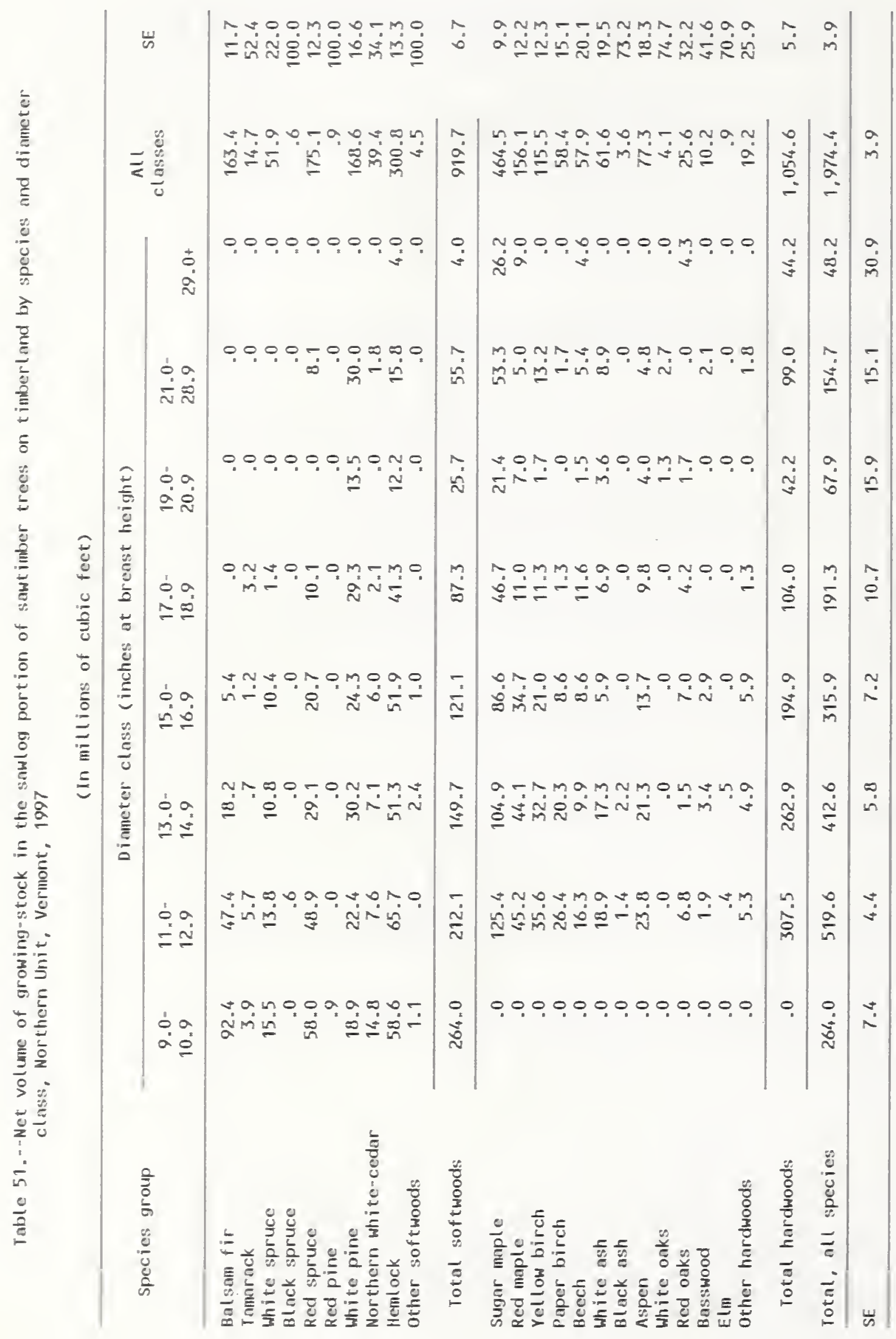


Sawtimber volume on timberland, for selected species and percent change, Northern Unit of Vermont, 1983 and 1997

(Volume increased by 33.8 percent for all species)

Sugar maple

Hemlock

Spruce

White pine

Red maple

Balsam fir

Yellow birch

Aspen

Ash

Beech

Paper birch

Oaks

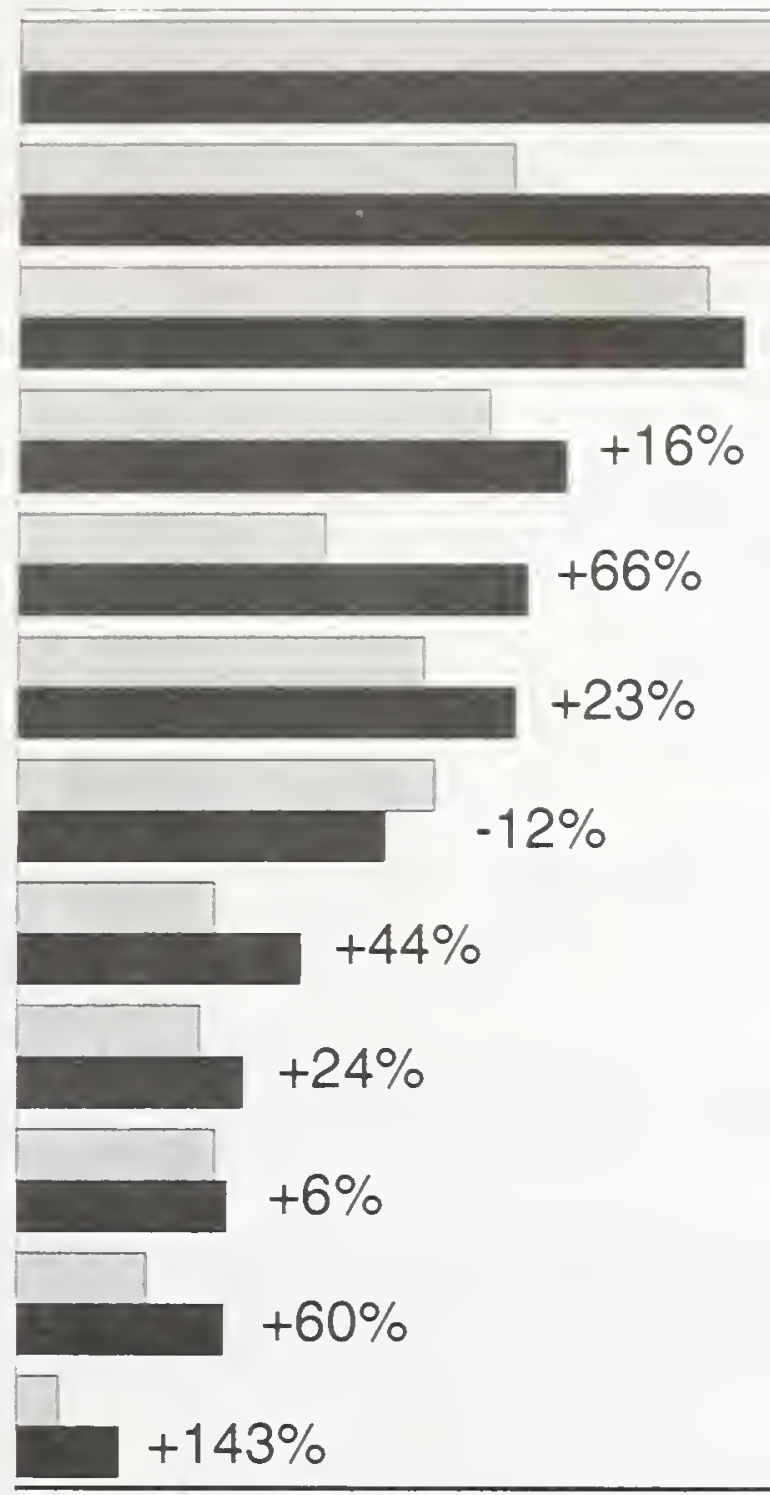

$+5 \%$ 


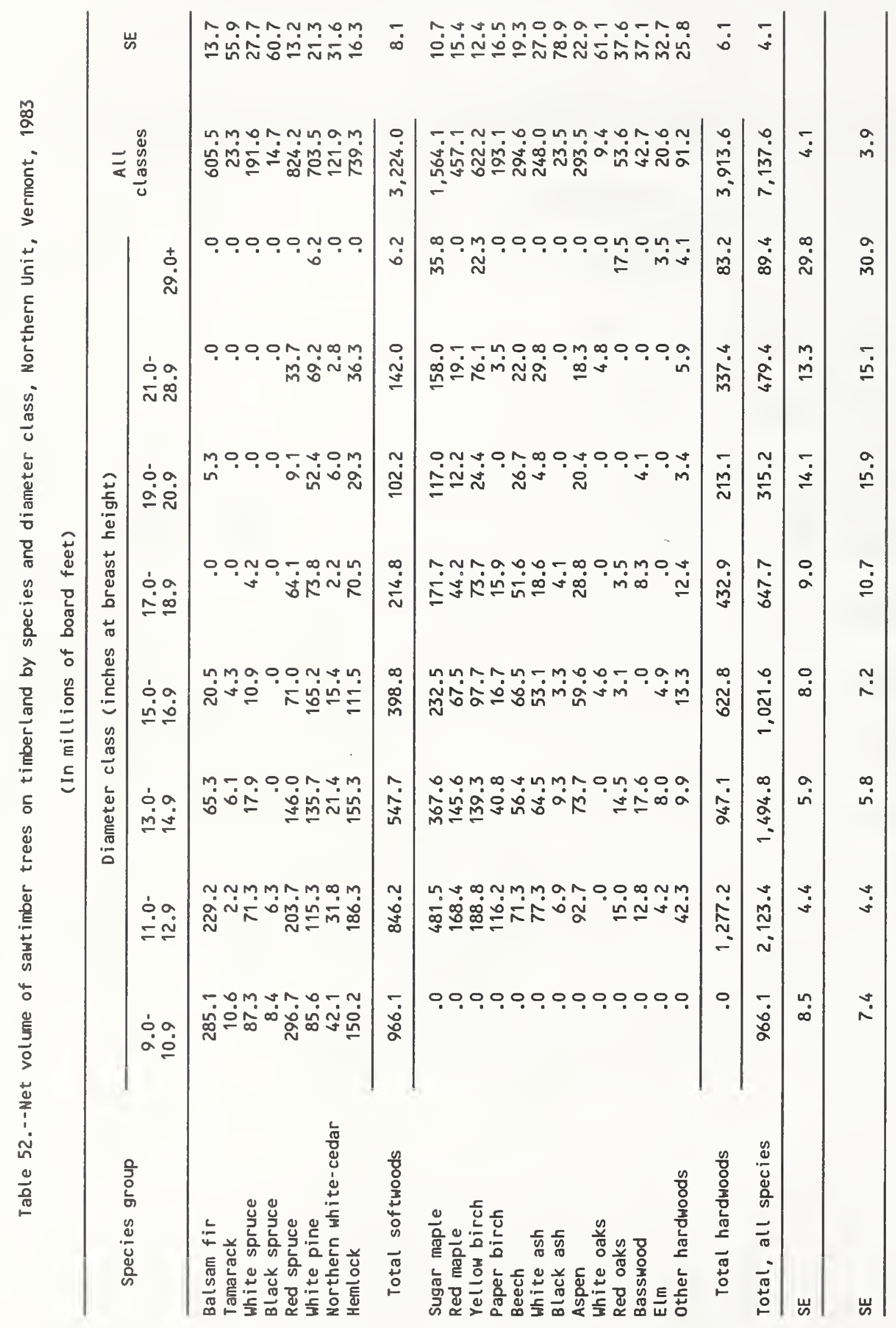




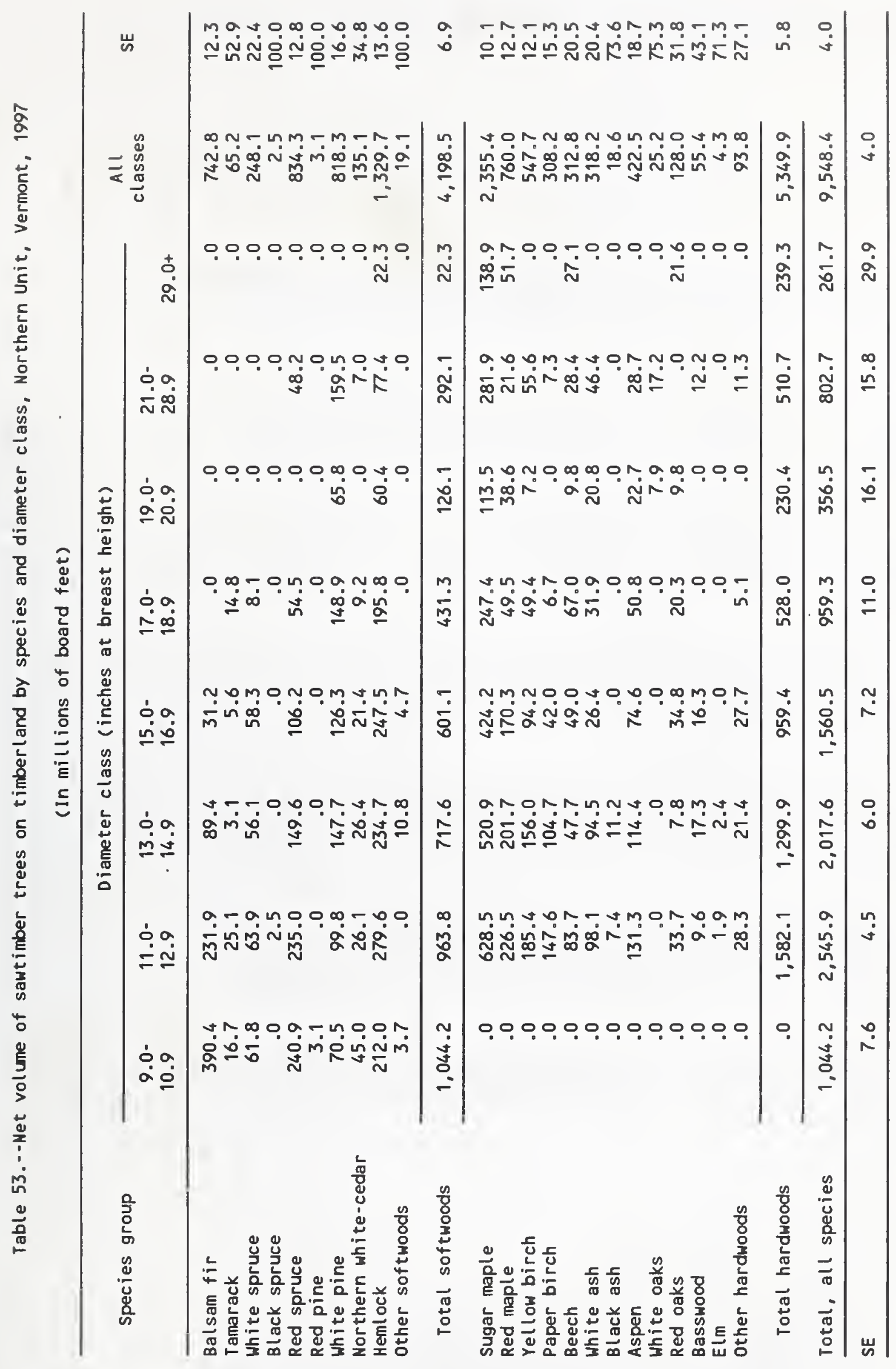




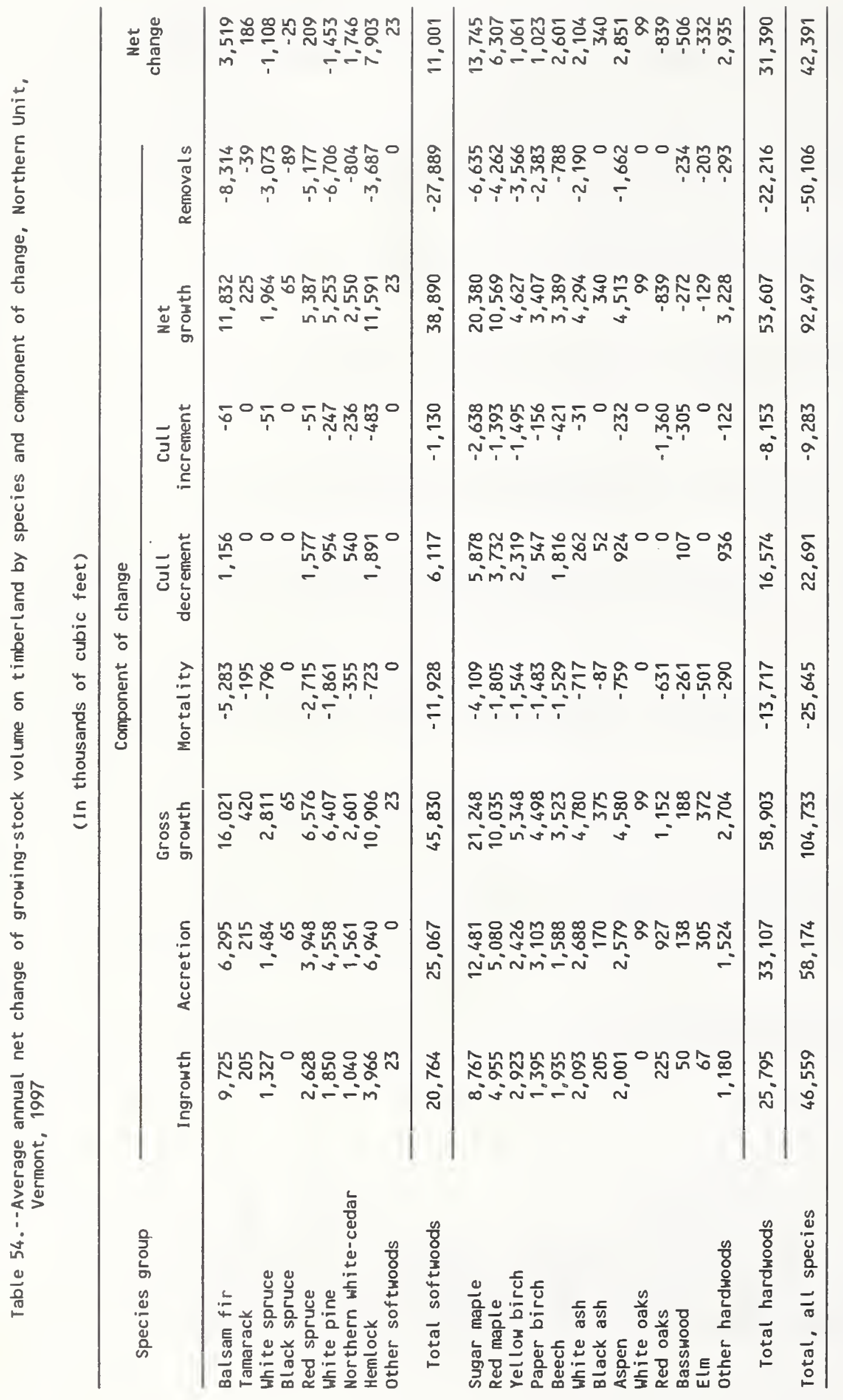




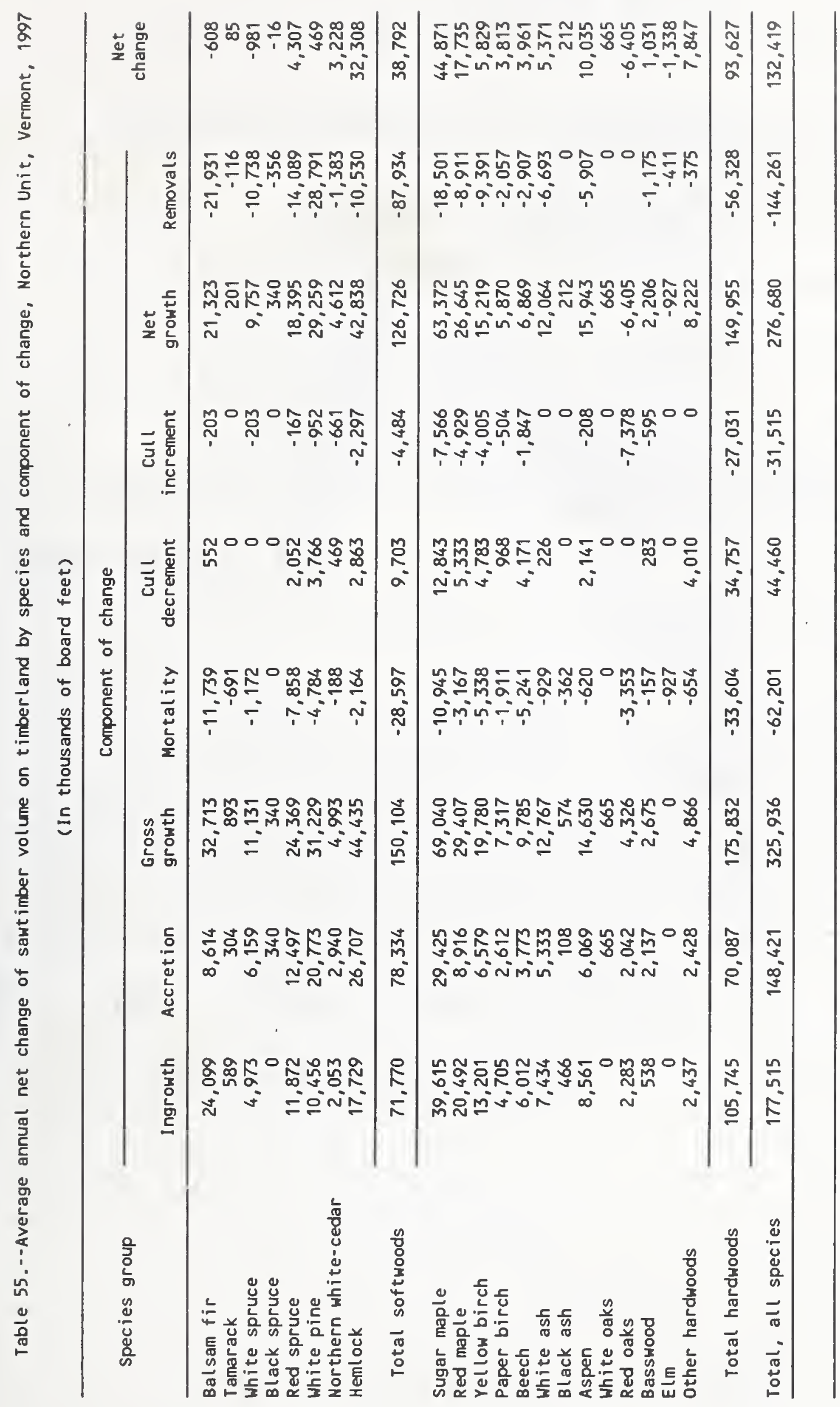


Average annual growth and removals of growing-stock volume and ratio of growth to removals for selected species on timberland, Northern Unit of Vermont, 1983-97

(Ratio of growth/removals for all species is $1.8: 1$ )

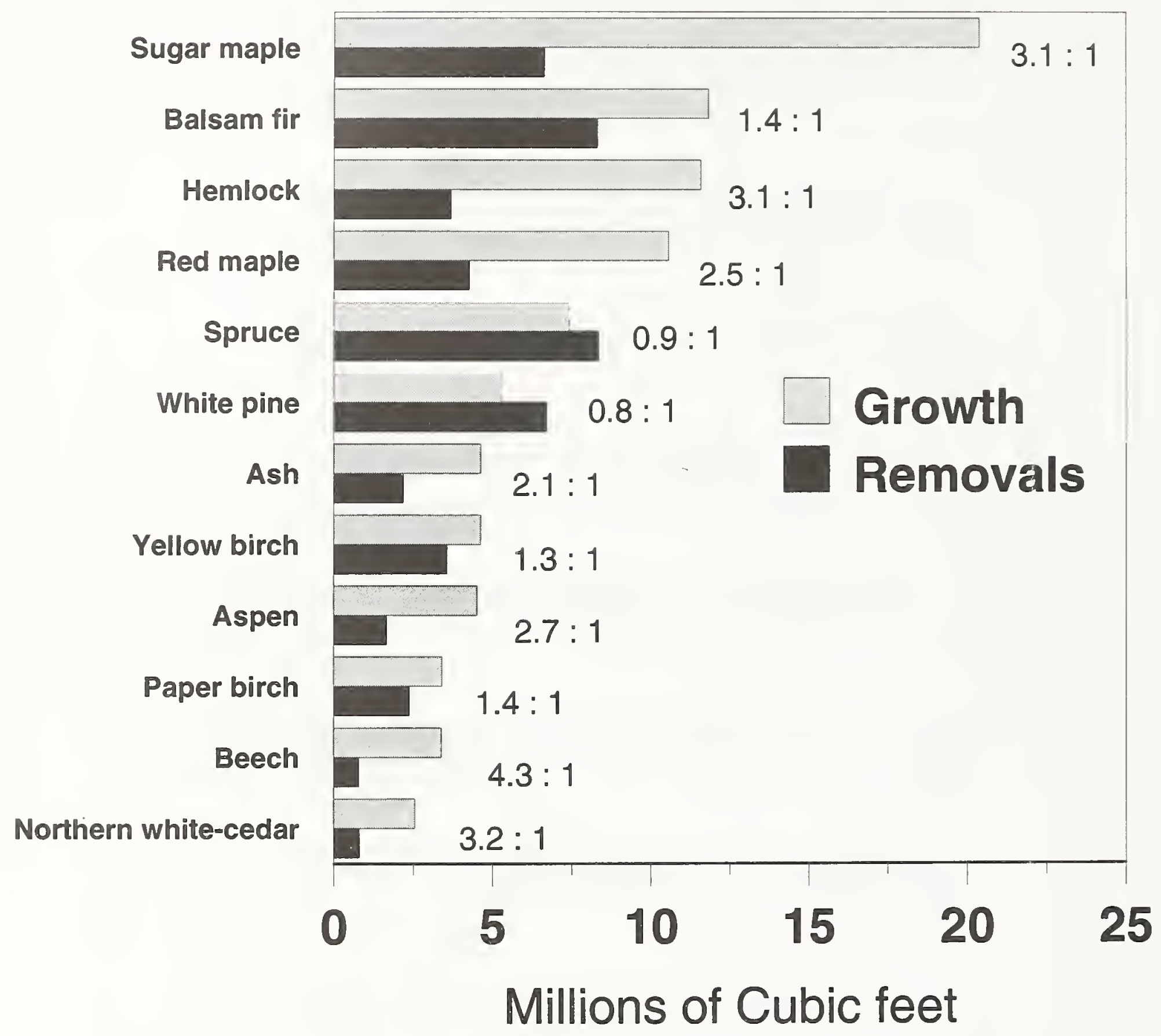




\section{SOUTHERN UNIT TABLES}

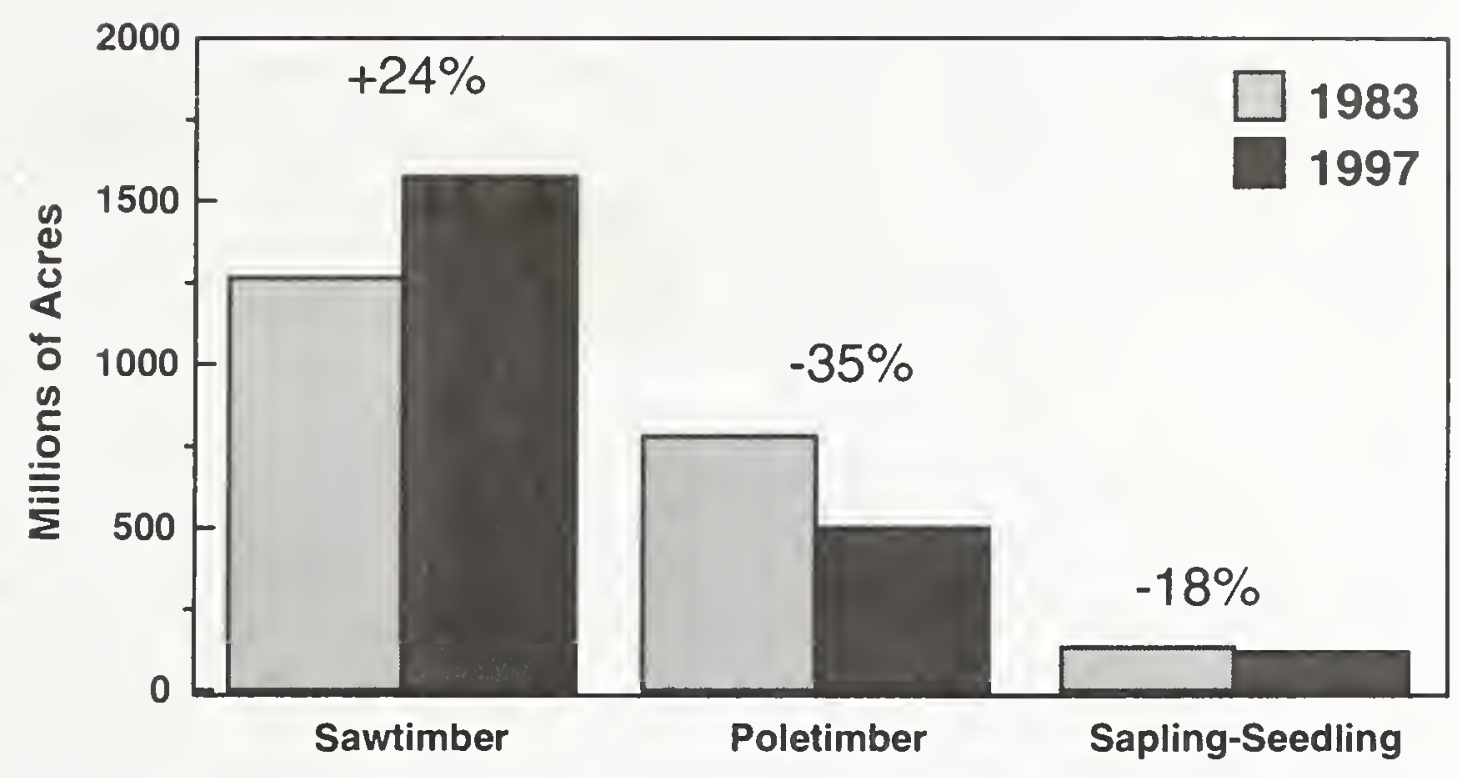

Southern Unit, area of timberland by stand-size class, 1983 and 1997

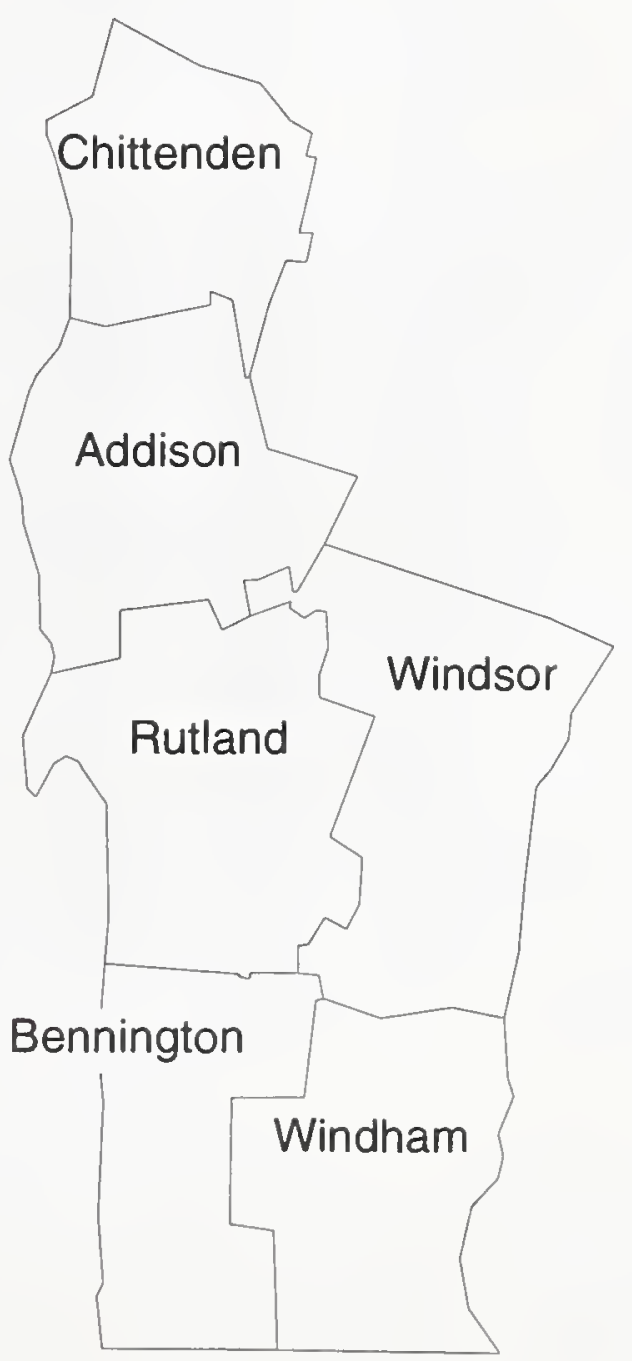


Table 56.--Area of timberland by forest type, forest-type group, and stand-size

class, Southern Unit, Vermont, 1983

(In thousands of acres)

\begin{tabular}{|c|c|c|c|c|c|c|}
\hline \multirow{2}{*}{ Forest type } & \multicolumn{4}{|c|}{ Stand-size class } & \multirow{2}{*}{$\begin{array}{c}\text { All } \\
\text { classes }\end{array}$} & \multirow{2}{*}{ SE } \\
\hline & $\begin{array}{l}\text { Saw- } \\
\text { timber }\end{array}$ & $\begin{array}{l}\text { Pole- } \\
\text { timber }\end{array}$ & $\begin{array}{l}\text { Sapl ing and } \\
\text { seedl ing }\end{array}$ & $\begin{array}{l}\text { Non- } \\
\text { stocked }\end{array}$ & & \\
\hline $\begin{array}{l}\text { Red pine } \\
\text { White pine } \\
\text { White pine/hemlock } \\
\text { Hemlock }\end{array}$ & $\begin{array}{r}7.5 \\
70.8 \\
35.1 \\
85.8\end{array}$ & $\begin{array}{r}.0 \\
41.6 \\
6.7 \\
14.1\end{array}$ & $\begin{array}{l}.0 \\
7.0 \\
.0 \\
.0\end{array}$ & $\begin{array}{l}.0 \\
.0 \\
.0 \\
.0\end{array}$ & $\begin{array}{r}7.5 \\
119.4 \\
41.8 \\
99.9\end{array}$ & $\begin{array}{r}100.0 \\
23.6 \\
40.6 \\
26.4\end{array}$ \\
\hline White/red pine group & 199.2 & 62.4 & 7.0 & .0 & 268.6 & 15.1 \\
\hline $\begin{array}{l}\text { Balsam fir } \\
\text { Red spruce } \\
\text { Red spruce/batsam fir }\end{array}$ & $\begin{array}{r}.0 \\
27.9 \\
6.9\end{array}$ & $\begin{array}{l}7.5 \\
7.2 \\
7.1\end{array}$ & $\begin{array}{r}7.1 \\
.0 \\
.0\end{array}$ & $\begin{array}{l}.0 \\
.0 \\
.0\end{array}$ & $\begin{array}{l}14.6 \\
35.1 \\
14.0\end{array}$ & $\begin{array}{l}70.7 \\
44.7 \\
70.7\end{array}$ \\
\hline Spruce/fir group & 34.9 & 21.8 & 7.1 & .0 & 63.8 & 32.8 \\
\hline Wh. pine/no.red oak/wh. ash & 7.0 & .0 & .0 & .0 & 7.0 & 100.0 \\
\hline Oak/pine group & 7.0 & .0 & .0 & .0 & 7.0 & 100.0 \\
\hline $\begin{array}{l}\text { White oak/red oak/hickory } \\
\text { White oak } \\
\text { Northern red oak } \\
\text { Hawthorn/reverting field } \\
\text { Red maple/central hardwood } \\
\text { Mixed central hardwoods }\end{array}$ & $\begin{array}{r}.0 \\
.0 \\
29.5 \\
.0 \\
.0 \\
28.5\end{array}$ & $\begin{array}{r}20.5 \\
6.7 \\
14.2 \\
.0 \\
6.4 \\
21.9\end{array}$ & $\begin{array}{r}.0 \\
.0 \\
.0 \\
7.1 \\
.0 \\
18.8\end{array}$ & $\begin{array}{l}.0 \\
.0 \\
.0 \\
.0 \\
.0 \\
.0\end{array}$ & $\begin{array}{r}20.5 \\
6.7 \\
43.7 \\
7.1 \\
6.4 \\
69.2\end{array}$ & $\begin{array}{r}57.0 \\
100.0 \\
40.8 \\
100.0 \\
100.0 \\
31.7\end{array}$ \\
\hline Oak/hickory group & 58.0 & 69.8 & 25.9 & .0 & 153.6 & 20.9 \\
\hline $\begin{array}{l}\text { Black ash/Amer. elm/red maple } \\
\text { Red maple(upland) } \\
\text { Cottonwood } \\
\text { Hillow }\end{array}$ & $\begin{array}{r}15.2 \\
.0 \\
.0 \\
.0\end{array}$ & $\begin{array}{r}26.5 \\
.0 \\
7.0 \\
.0\end{array}$ & $\begin{array}{r}7.2 \\
6.4 \\
.0 \\
5.0\end{array}$ & $\begin{array}{l}.0 \\
.0 \\
.0 \\
.0\end{array}$ & $\begin{array}{r}48.9 \\
6.4 \\
7.0 \\
5.0\end{array}$ & $\begin{array}{r}38.0 \\
100.0 \\
100.0 \\
100.0\end{array}$ \\
\hline Elm/ash/red maple group & 15.2 & 33.5 & 18.6 & .0 & 67.3 & 30.7 \\
\hline $\begin{array}{l}\text { Sugar maple/beech/yel low birch } \\
\text { Black Cherry } \\
\text { Red maple/northern hardwoods } \\
\text { Pin cherry/reverting field } \\
\text { Mixed northern hardwoods }\end{array}$ & $\begin{array}{r}776.6 \\
.0 \\
85.0 \\
.0 \\
61.0\end{array}$ & $\begin{array}{r}284.1 \\
4.9 \\
104.6 \\
.0 \\
94.4\end{array}$ & $\begin{array}{r}26.9 \\
7.7 \\
.0 \\
5.6 \\
34.2\end{array}$ & $\begin{array}{l}.0 \\
.0 \\
.0 \\
5.6 \\
.0\end{array}$ & $\begin{array}{r}1,087.6 \\
12.6 \\
189.6 \\
11.2 \\
189.6\end{array}$ & $\begin{array}{r}5.6 \\
72.5 \\
18.6 \\
17.2 \\
17.6\end{array}$ \\
\hline Northern hardwoods group & 922.5 & 488.0 & 74.4 & 5.6 & $1,490.5$ & 3.8 \\
\hline $\begin{array}{l}\text { Aspen } \\
\text { Paper birch } \\
\text { Gray birch }\end{array}$ & $\begin{array}{r}7.0 \\
35.2 \\
.0\end{array}$ & $\begin{array}{r}29.4 \\
77.7 \\
6.8\end{array}$ & $\begin{array}{r}14.0 \\
.0 \\
.0\end{array}$ & $\begin{array}{l}.0 \\
.0 \\
.0\end{array}$ & $\begin{array}{r}50.4 \\
112.9 \\
6.8\end{array}$ & $\begin{array}{r}37.7 \\
24.3 \\
100.0\end{array}$ \\
\hline Aspen/birch group & 42.2 & 113.9 & 14.0 & .0 & 170.0 & 19.8 \\
\hline All forest types & $1,278.9$ & 789.3 & 147.0 & 5.6 & $2,220.8$ & .8 \\
\hline SE & 4.7 & 7.7 & 17.3 & 100.0 & .8 & \\
\hline
\end{tabular}


Table 57.--Area of timberland by forest type, forest-type group, and stand-size class, Southern Unit, Vermont, 1997

(In thousands of acres)

\begin{tabular}{|c|c|c|c|c|c|c|}
\hline \multirow{2}{*}{ For } & \multicolumn{4}{|c|}{ Stand-size class } & \multirow{2}{*}{$\begin{array}{c}\text { All } \\
\text { classes }\end{array}$} & \multirow{2}{*}{ SE } \\
\hline & $\begin{array}{l}\text { Saw- } \\
\text { t imber }\end{array}$ & $\begin{array}{l}\text { Pole- } \\
\text { timber }\end{array}$ & $\begin{array}{l}\text { Sapl ing and } \\
\text { seedl ing }\end{array}$ & $\begin{array}{c}\text { Non- } \\
\text { stocked }\end{array}$ & & \\
\hline Red pine & 3.3 & .0 & .0 & .0 & 3.3 & 100.0 \\
\hline White pine & 98.7 & 3.7 & .0 & .0 & 102.4 & 22.2 \\
\hline Whitc pine/hemlock & 48.4 & 6.4 & 3.5 & .5 & 58.8 & 29.3 \\
\hline Heml ock & 91.8 & 1.7 & .0 & .0 & 93.5 & 24.3 \\
\hline White/red pine group & 242.3 & 11.8 & 3.5 & .5 & 258.1 & 13.3 \\
\hline Balsam fir & 6.0 & 5.2 & 6.6 & .0 & 17.8 & 64.8 \\
\hline Red spruce & 25.9 & .0 & .0 & .0 & 25.9 & 47.5 \\
\hline Red spruce/balsam fir & 8.2 & .0 & 7.4 & .0 & 15.6 & 64.2 \\
\hline Norway spruce & 1.5 & .0 & .0 & .0 & 1.5 & 100.0 \\
\hline Nor thern white-cedar & 4.9 & .0 & .0 & .0 & 4.9 & 100.0 \\
\hline Spruce/fir group & 46.4 & 5.2 & 14.0 & .0 & 65.6 & 30.6 \\
\hline Wh. pine/no.red oak/wh. ash & 17.5 & 4.8 & .0 & .0 & 22.4 & 50.2 \\
\hline Oak/pine group & 17.5 & 4.8 & .0 & .0 & 22.4 & 50.2 \\
\hline Chestnut oak & 7.5 & .0 & .0 & .0 & 7.5 & 100.0 \\
\hline White oak/red oak/hickory & 15.9 & 12.6 & .0 & .0 & 28.5 & 50.4 \\
\hline Northern red oak & 29.3 & 6.6 & .0 & .0 & 35.9 & 44.1 \\
\hline Mixed central hardwoods & 52.4 & 24.6 & .0 & .0 & 77.1 & 28.5 \\
\hline Oak/hickory group & 105.2 & 43.8 & .0 & .0 & 149.0 & 20.5 \\
\hline Black ash/Amer. elm/red maple & 7.1 & .0 & 9.1 & .0 & 16.2 & 57.7 \\
\hline Willow & .0 & .0 & 7.1 & .0 & 7.1 & 79.4 \\
\hline American elm/green ash & .0 & 4.3 & .0 & .0 & 4.3 & 100.0 \\
\hline Elm/ash/red maple group & 7.1 & 4.3 & 16.3 & .0 & 27.7 & 41.2 \\
\hline Sugar maple/beech/yell ow birch & 800.9 & 216.8 & 17.0 & .0 & $1,034.7$ & $\begin{array}{r}5.7 \\
15.1\end{array}$ \\
\hline $\begin{array}{l}\text { Red maple/northern hardwoods } \\
\text { Pin cherry/reverting field }\end{array}$ & $\begin{array}{r}147.0 \\
.0\end{array}$ & $\begin{array}{r}91.8 \\
8.4\end{array}$ & $\begin{array}{r}7.6 \\
39.5\end{array}$ & $\begin{array}{l}.0 \\
.0\end{array}$ & $\begin{array}{r}246.4 \\
47.9\end{array}$ & $\begin{array}{l}15.1 \\
30.0\end{array}$ \\
\hline Mixed nor thern hardwoods & 164.9 & 91.5 & 10.3 & .0 & 266.7 & 14.8 \\
\hline Northern hardwoods group & $1,112.8$ & 408.4 & 74.4 & .0 & $1,595.6$ & 3.5 \\
\hline Aspen & 15.0 & 10.3 & 12.5 & .0 & 37.9 & 40.4 \\
\hline Paper birch & 37.4 & 23.2 & .0 & .0 & 60.6 & 31.3 \\
\hline Aspen/birch group & 52.4 & 33.5 & 12.5 & .0 & 98.4 & 24.1 \\
\hline All forest types & $1,583.7$ & 511.9 & 120.7 & .5 & $2,216.8$ & 1.5 \\
\hline SE & 3.5 & 9.8 & 19.3 & 100.0 & 1.5 & \\
\hline SE & 4.7 & 7.7 & 17.3 & 100.0 & .8 & \\
\hline
\end{tabular}




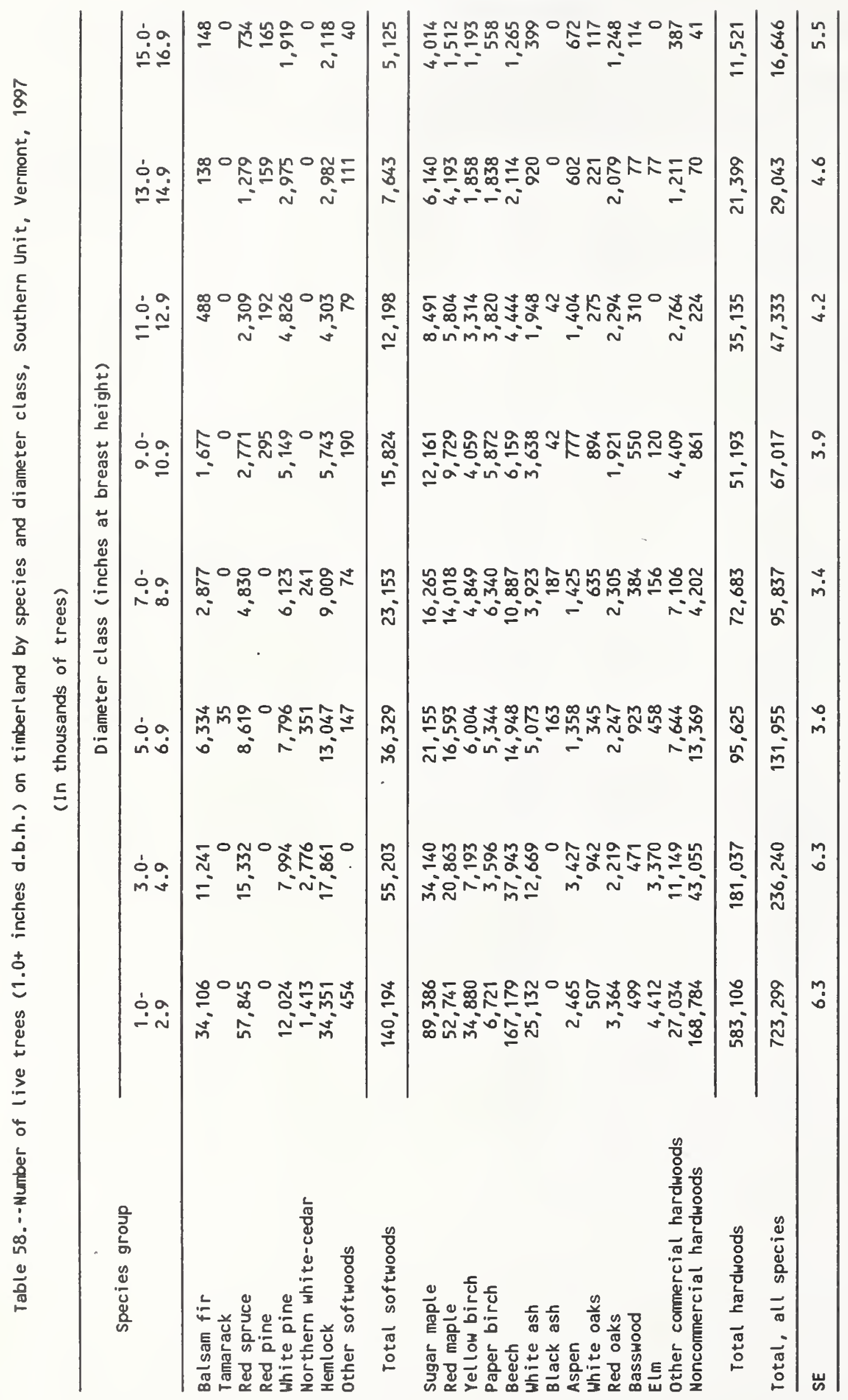




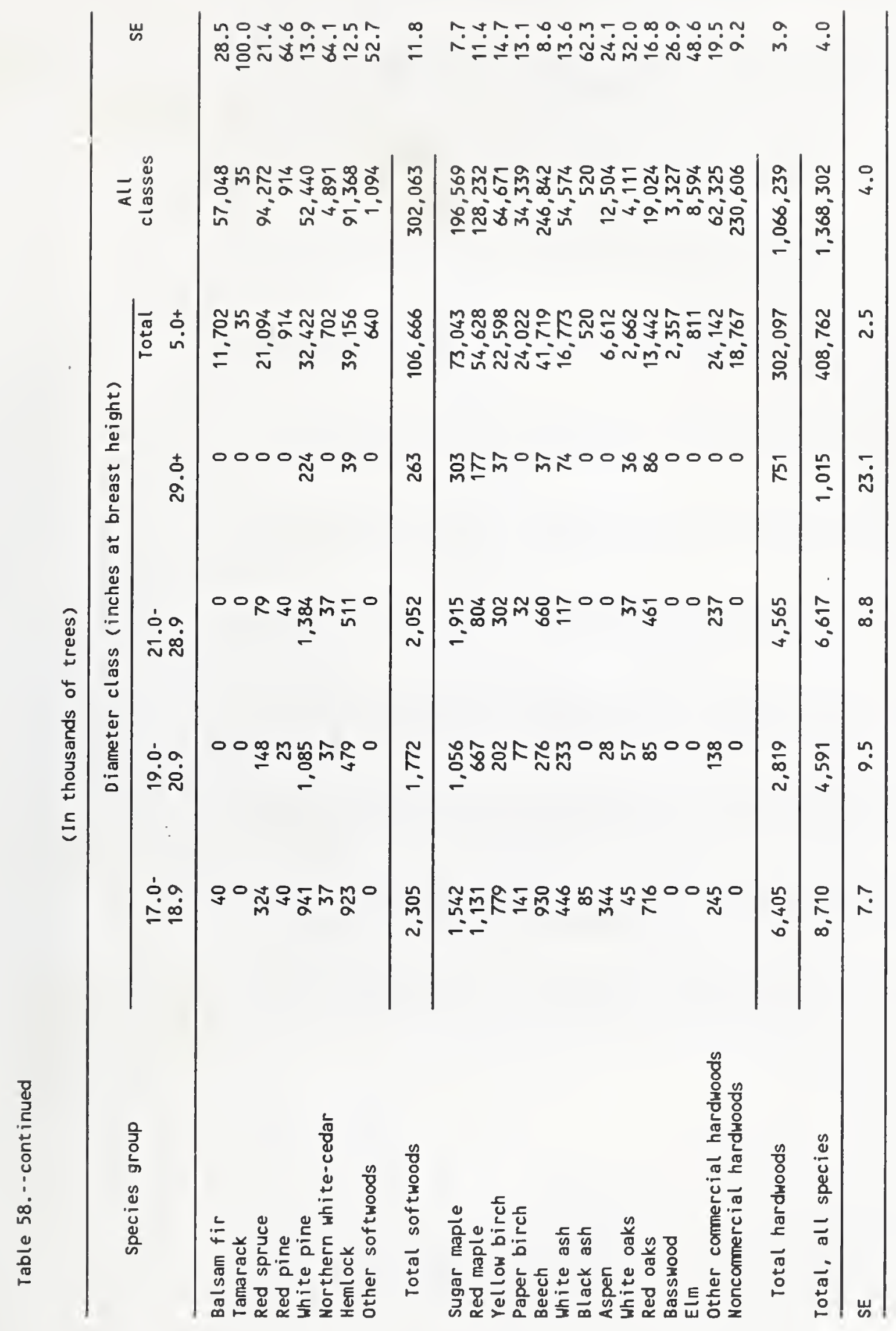




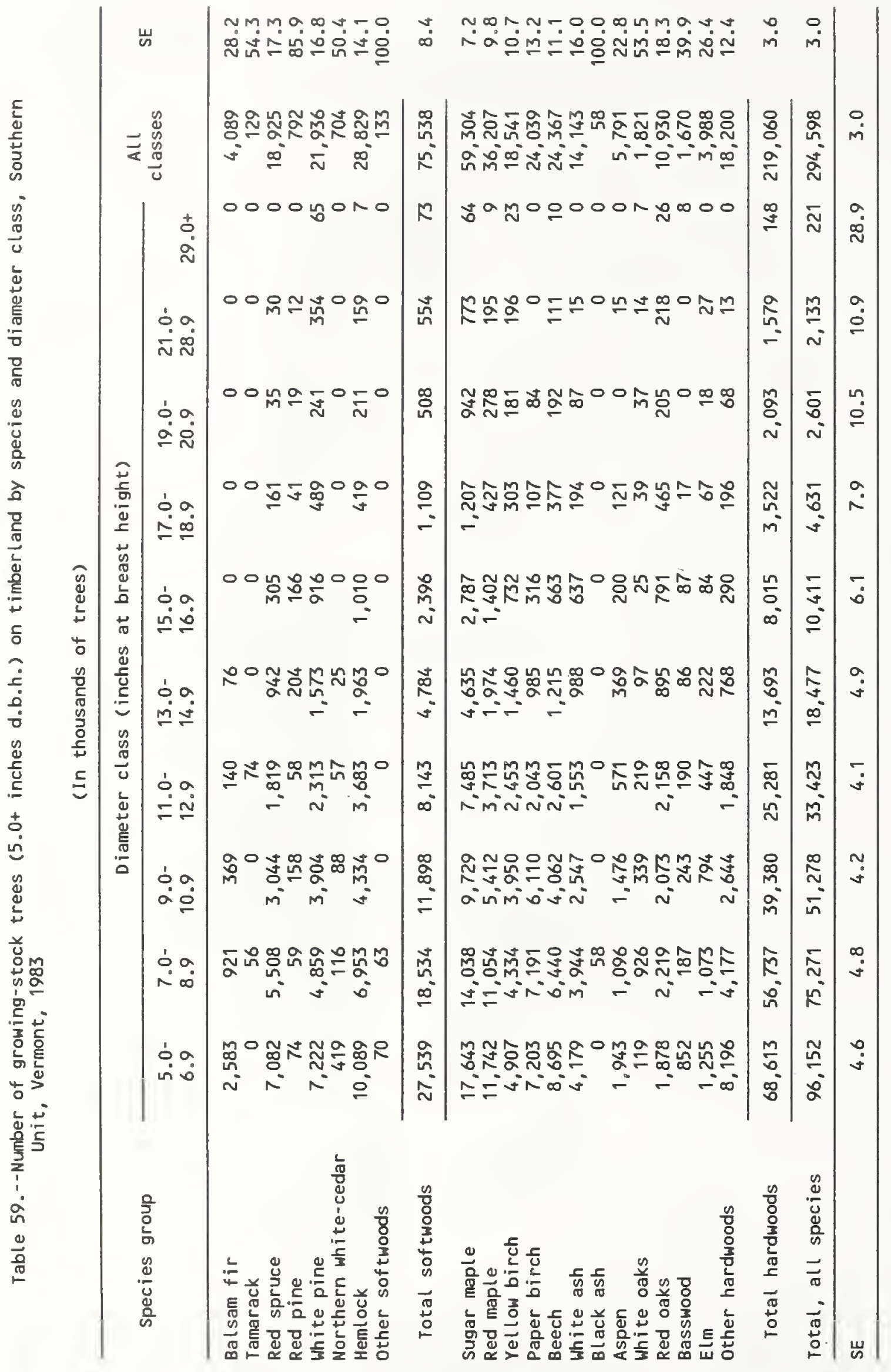




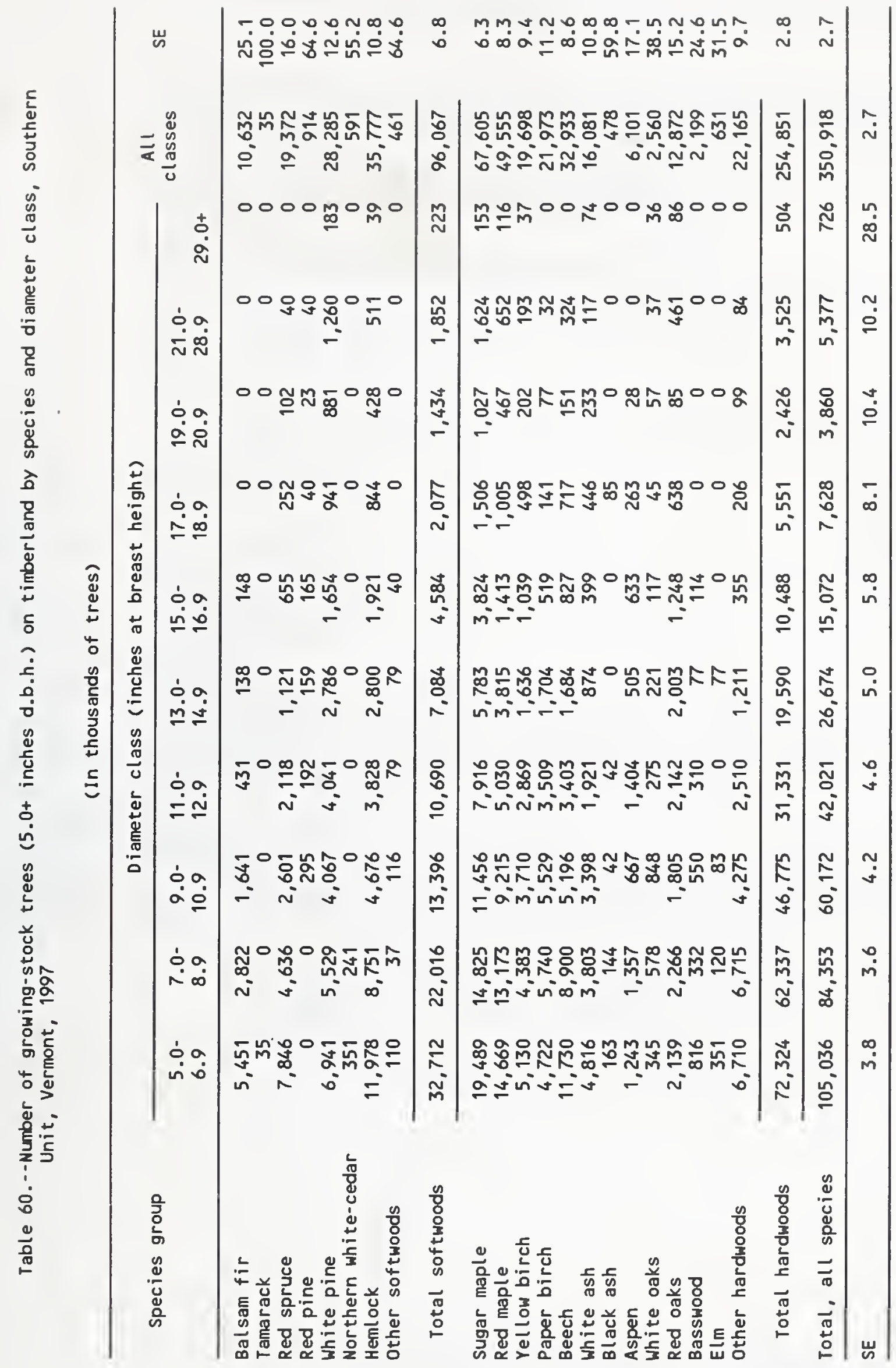




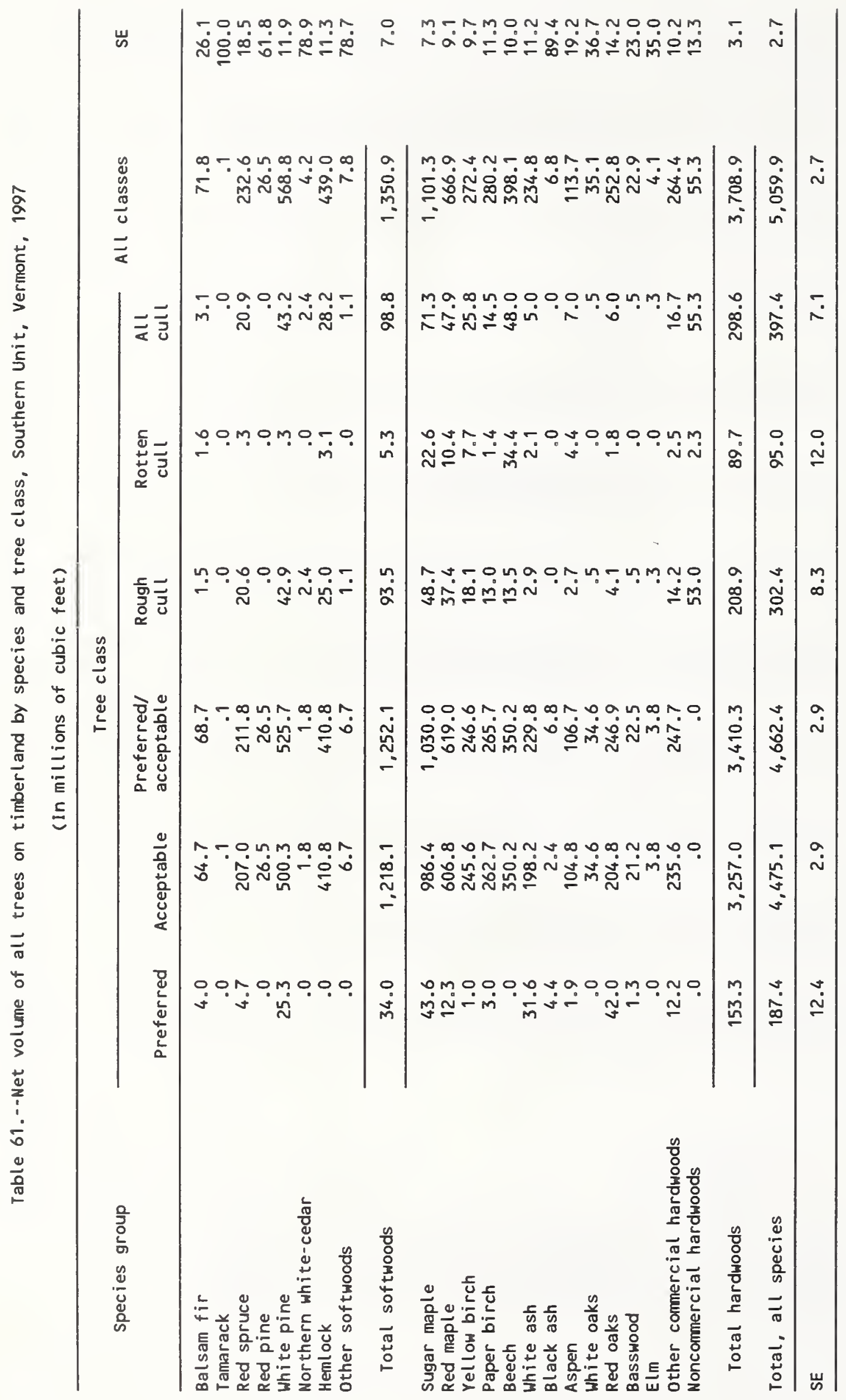


Volume of all live trees on timberland, for selected species and percent change, Southern Unit of Vermont, 1983 and 1997

(Volume increased by 25.1 percent for all species)

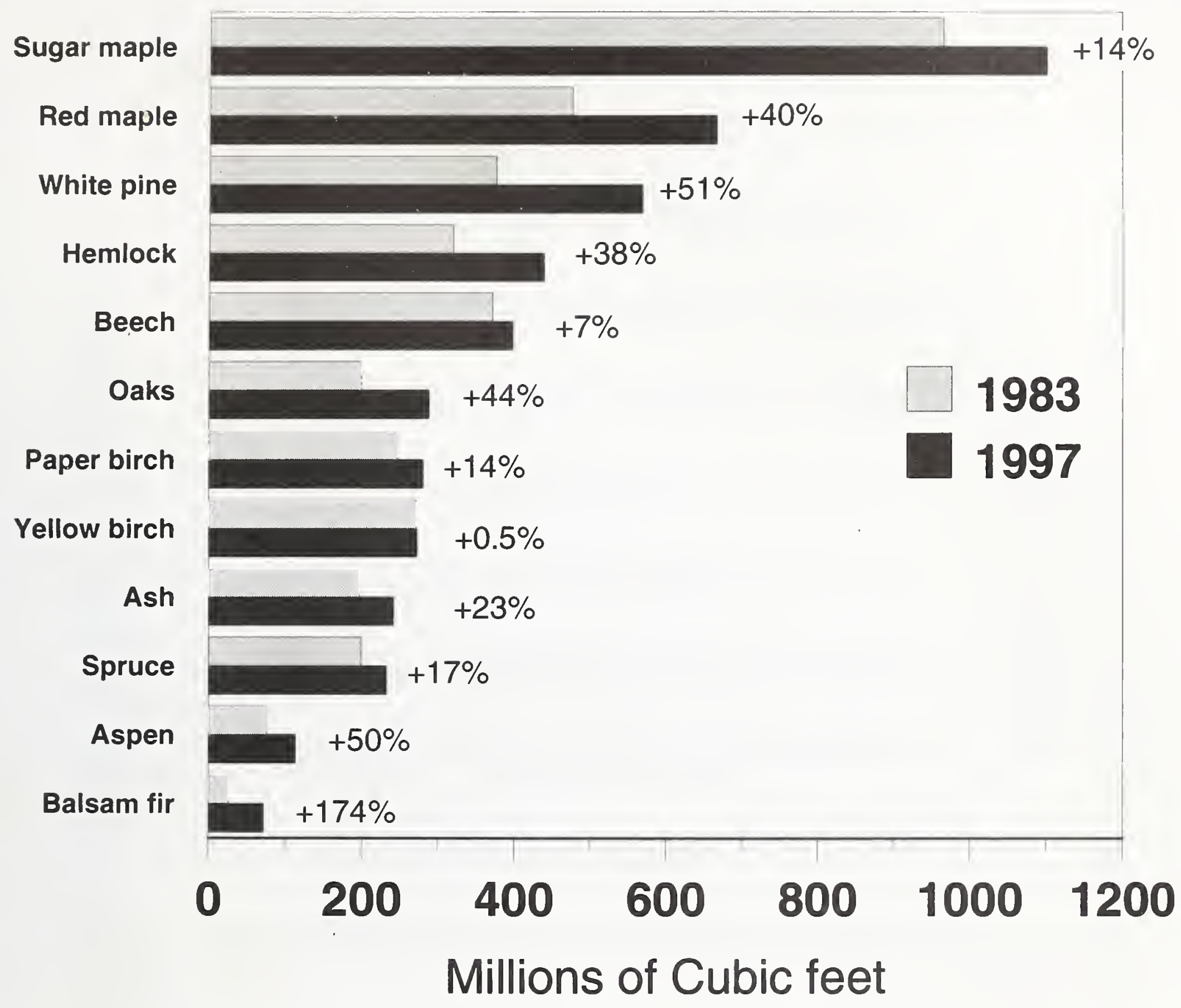




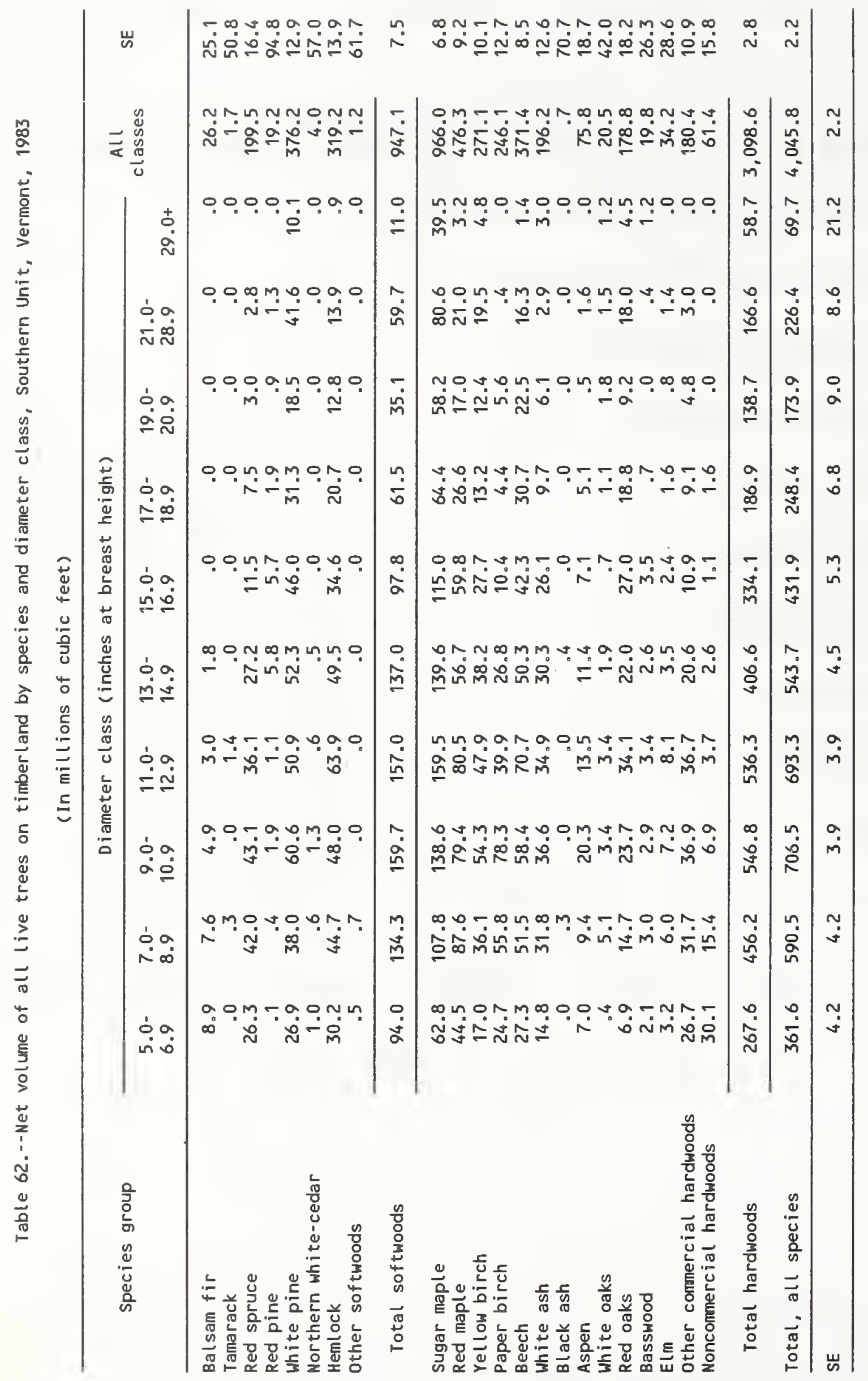




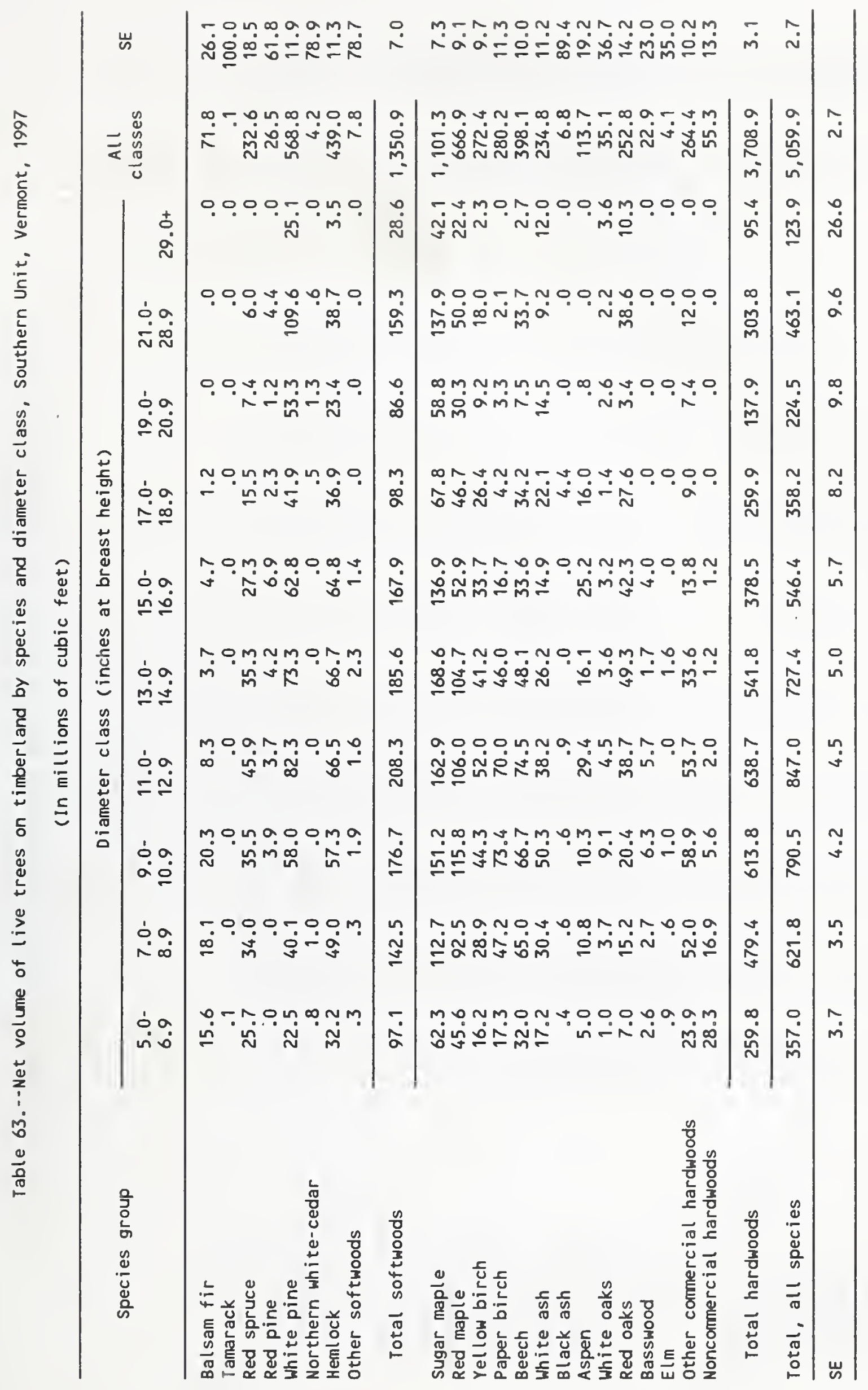




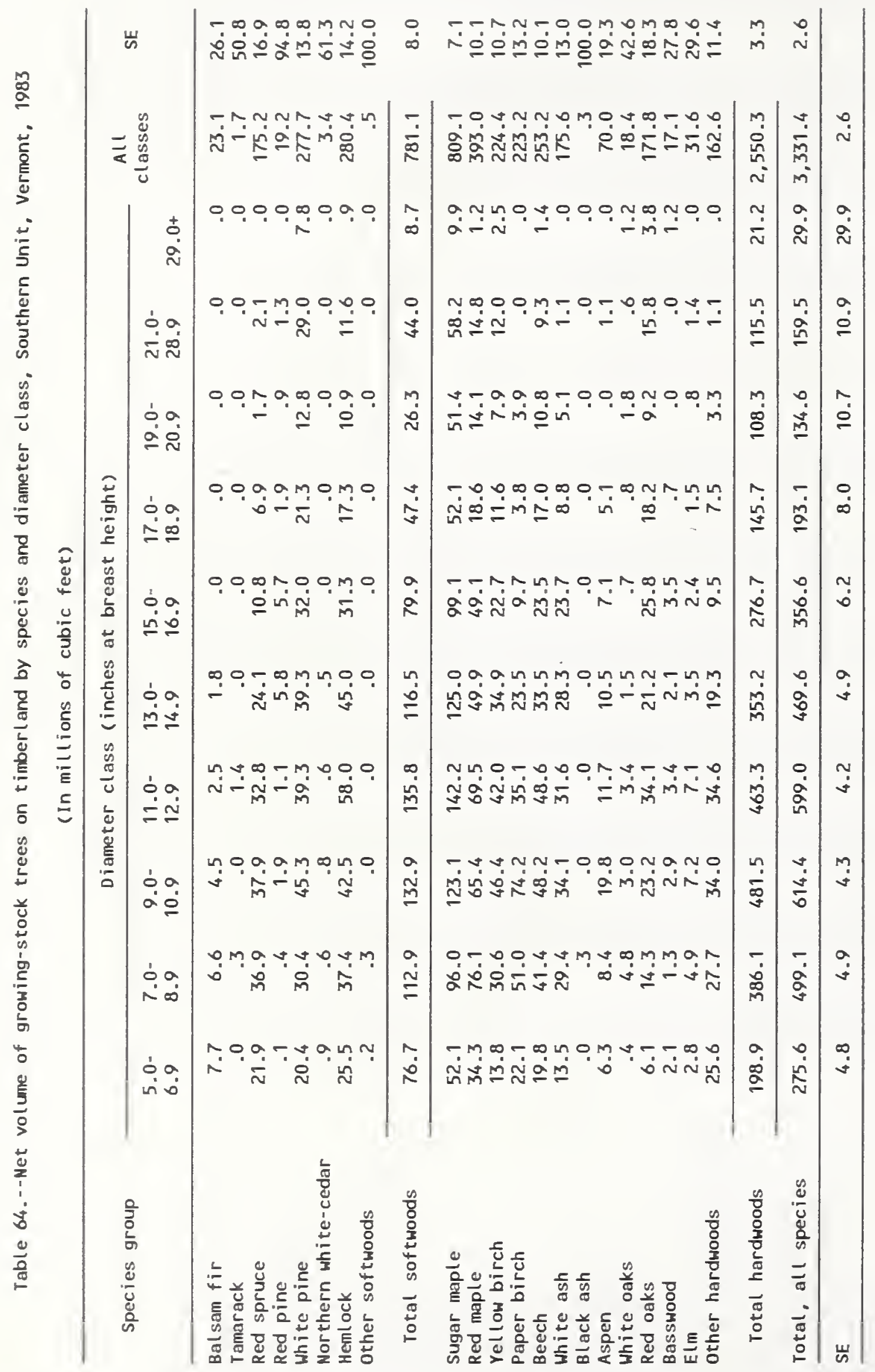




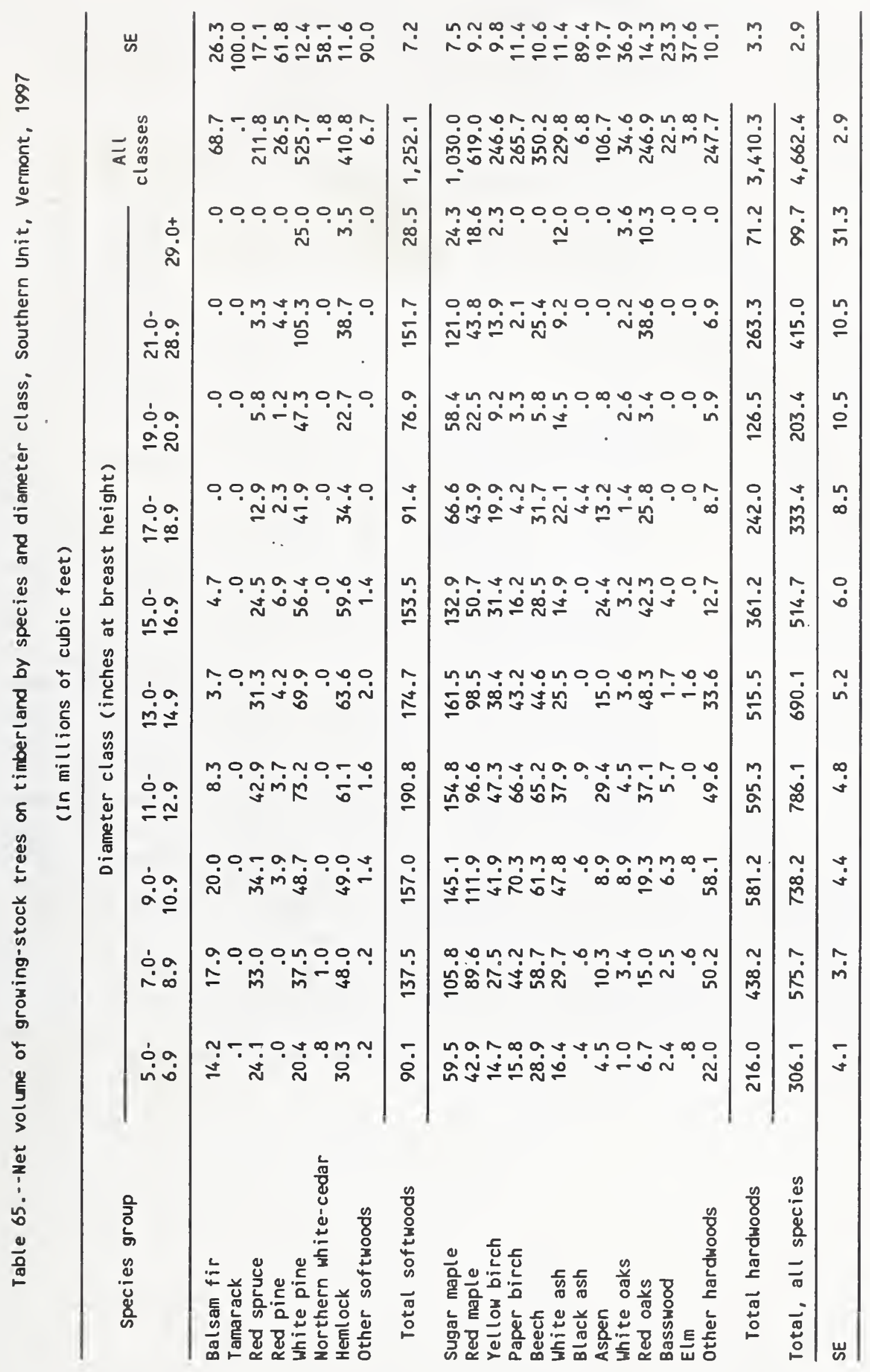


Table 66.--Net volume of growing-stock trees on timberland by species and stand-size class, Southern Unit, Vermont, 1983

(In millions of cubic feet)

\begin{tabular}{|c|c|c|c|c|c|c|}
\hline \multirow{2}{*}{ Species group } & \multicolumn{4}{|c|}{ Stand-size class } & \multirow{2}{*}{$\begin{array}{c}\text { All } \\
\text { classes }\end{array}$} & \multirow{2}{*}{ SE } \\
\hline & $\begin{array}{l}\text { Saw- } \\
\text { timber }\end{array}$ & $\begin{array}{l}\text { Pole- } \\
\text { timber }\end{array}$ & $\begin{array}{l}\text { Sapling and } \\
\text { seedl ing }\end{array}$ & $\begin{array}{l}\text { Non- } \\
\text { stocked }\end{array}$ & & \\
\hline Balsam fir & 15.0 & 7.6 & .5 & .0 & 23.1 & 26.1 \\
\hline Tamarack & .5 & 1.2 & .0 & .0 & 1.7 & 50.8 \\
\hline Red spruce & 111.2 & 63.6 & .3 & .0 & 175.2 & 16.9 \\
\hline Red pine & 18.1 & 1.0 & .0 & .0 & 19.2 & 94.8 \\
\hline White pine & 166.5 & 104.1 & 7.1 & .0 & 277.7 & 13.8 \\
\hline Northern white-cedar & 1.9 & 1.0 & .4 & .0 & 3.4 & 61.3 \\
\hline Hemlock & 232.3 & 48.1 & .0 & .0 & 280.4 & 14.2 \\
\hline Other sof twoods & .0 & .5 & .0 & .0 & .5 & 100.0 \\
\hline Total softwoods & 545.6 & 227.1 & 8.4 & .0 & 781.1 & 8.0 \\
\hline sugar maple & 648.8 & 158.8 & 1.4 & .0 & 809.1 & 7.1 \\
\hline Red maple & 235.4 & 157.6 & .0 & .0 & 393.0 & 10.1 \\
\hline Yellow birch & 156.1 & 68.3 & .0 & .0 & 224.4 & 10.7 \\
\hline Paper birch & 94.1 & 129.1 & .0 & .0 & 223.2 & 13.2 \\
\hline Beech & 186.3 & 66.0 & 1.0 & .0 & 253.2 & 10.1 \\
\hline White ash & 79.1 & 94.8 & 1.7 & .0 & 175.6 & 13.0 \\
\hline Black ash & .0 & .3 & .0 & .0 & .3 & 100.0 \\
\hline Aspen & 25.8 & 42.7 & 1.6 & .0 & 70.0 & 19.3 \\
\hline White oaks & 3.3 & 14.4 & .6 & .0 & 18.4 & 42.6 \\
\hline Red oaks & 97.2 & 72.8 & 1.8 & .0 & 171.8 & 18.3 \\
\hline Basswood & 10.1 & 7.0 & .0 & .0 & 17.1 & 27.8 \\
\hline Elm & 16.0 & 14.3 & 1.2 & .0 & 31.6 & 29.6 \\
\hline Other hardwoods & 92.3 & 69.1 & 1.2 & .0 & 162.6 & 11.4 \\
\hline Total hardwoods & $1,644.5$ & 895.2 & 10.6 & .0 & $2,550.3$ & 3.3 \\
\hline Total, all species & $2,190.1$ & $1,122.3$ & 19.0 & .0 & $3,331.4$ & 2.6 \\
\hline SE & 5.4 & 9.2 & 28.5 & .0 & 2.6 & \\
\hline
\end{tabular}


Table 67.--Net volume of growing-stock trees on timberland by species and stand-size class, Southern Unit, Vermont, 1997

(In millions of cubic feet)

\begin{tabular}{|c|c|c|c|c|c|c|}
\hline \multirow{2}{*}{ Species group } & \multicolumn{4}{|c|}{ Stand-size class } & \multirow{2}{*}{$\begin{array}{c}\text { All } \\
\text { classes }\end{array}$} & \multirow{2}{*}{ SE } \\
\hline & $\begin{array}{l}\text { Saw- } \\
\text { timber }\end{array}$ & $\begin{array}{l}\text { Pole- } \\
\text { timber }\end{array}$ & $\begin{array}{l}\text { Sapl ing and } \\
\text { seedl ing }\end{array}$ & $\begin{array}{c}\text { Non- } \\
\text { stocked }\end{array}$ & & \\
\hline Balsam fir & 40.7 & 25.5 & 2.5 & .0 & 68.7 & 26.3 \\
\hline Tamarack & .1 & .0 & .0 & .0 & .1 & 100.0 \\
\hline Red spruce & 179.0 & 31.4 & 1.3 & .0 & 211.8 & 17.1 \\
\hline Red pine & 21.6 & .0 & 4.9 & .0 & 26.5 & 61.8 \\
\hline White pine & 462.7 & 58.3 & 4.7 & .0 & 525.7 & 12.4 \\
\hline Nor thern white-cedar & 1.3 & .0 & .5 & .0 & 1.8 & 58.1 \\
\hline Heml ock & 392.9 & 17.9 & .0 & .0 & 410.8 & 11.6 \\
\hline Other sof twoods & 6.5 & .3 & .0 & .0 & 6.7 & 90.0 \\
\hline Total sof twoods & $1,104.8$ & 133.4 & 14.0 & .0 & $1,252.1$ & 7.2 \\
\hline Sugar maple & 891.4 & 136.2 & 2.3 & .0 & $1,030.0$ & 7.5 \\
\hline Red maple & 472.9 & 144.5 & 1.6 & .0 & 619.0 & 9.2 \\
\hline Yellow birch & 204.3 & 42.2 & .1 & .0 & 246.6 & 9.8 \\
\hline Paper birch & 195.1 & 70.7 & .0 & .0 & 265.7 & 11.4 \\
\hline Beech & 306.9 & 38.4 & 4.8 & .0 & 350.2 & 10.6 \\
\hline White ash & 160.7 & 66.1 & 3.0 & .0 & 229.8 & 11.4 \\
\hline Black ash & 6.3 & .1 & .5 & .0 & 6.8 & 89.4 \\
\hline Aspen & 82.8 & 21.3 & 2.5 & .0 & 106.7 & 19.7 \\
\hline White oaks & 28.2 & 6.4 & .0 & .0 & 34.6 & 36.9 \\
\hline Red oaks & 189.8 & 57.0 & .0 & .0 & 246.9 & 14.3 \\
\hline Basswood & 19.2 & 3.3 & .0 & .0 & 22.5 & 23.3 \\
\hline Elm & 2.6 & 1.0 & .2 & .0 & 3.8 & 37.6 \\
\hline Other hardwoods & 180.9 & 64.2 & 2.5 & .0 & 247.7 & 10.1 \\
\hline Total hardwoods & $2,741.2$ & 651.5 & 17.6 & .0 & $3,410.3$ & 3.3 \\
\hline Total, all species & $3,846.0$ & 784.9 & 31.6 & .0 & $4,662.4$ & 2.9 \\
\hline SE & 4.3 & 11.3 & 34.7 & .0 & 2.9 & \\
\hline
\end{tabular}


Percent of growing-stock volume by forest-type group Southern Unit of Vermont, 1997

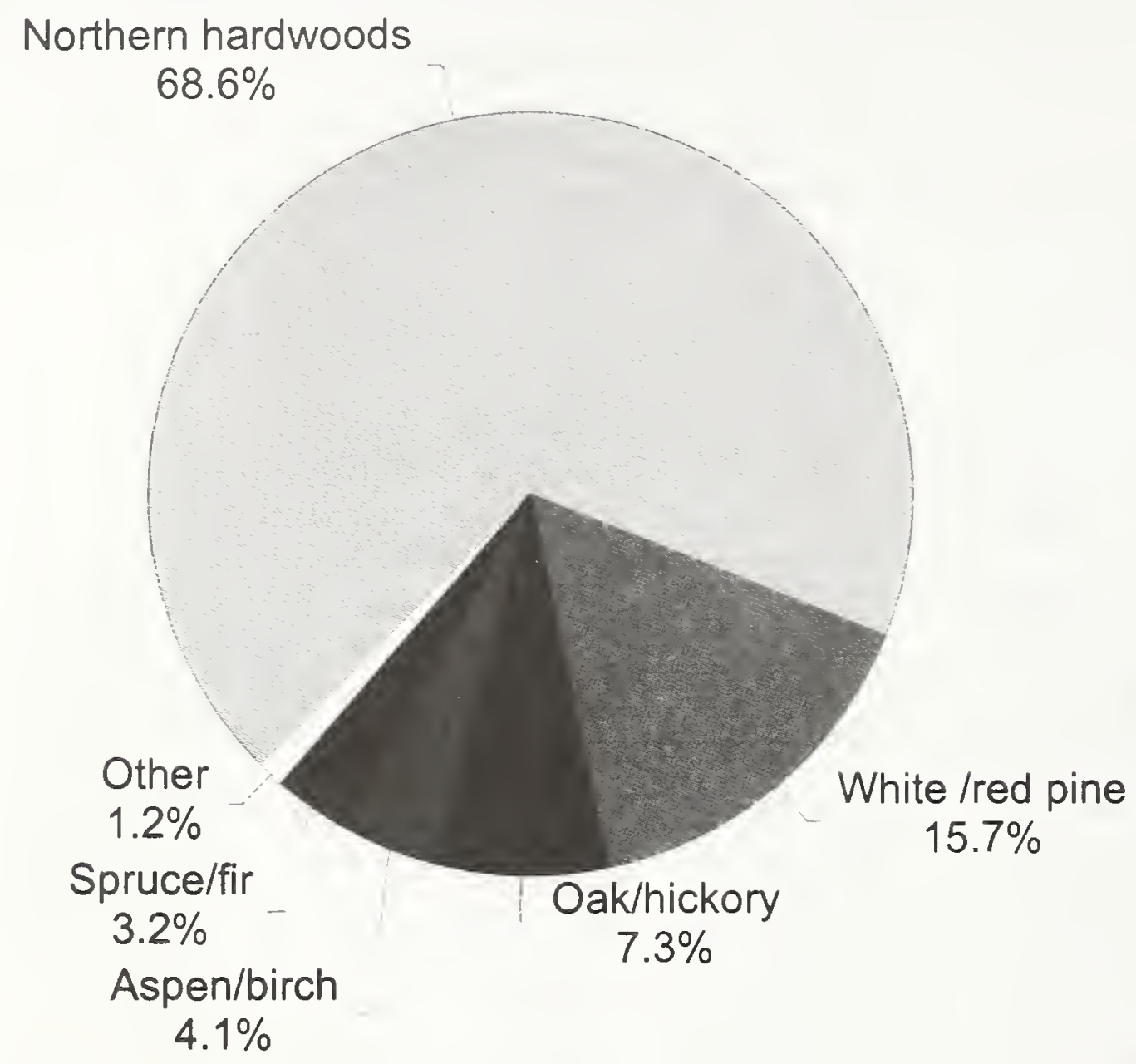


Table 68.-- Net volume of growing-stock trees on timberland by forest type and stand-size class, Southern Unit, Vermont, 1997

(In millions of cubic feet)

\begin{tabular}{|c|c|c|c|c|c|c|}
\hline \multirow{2}{*}{ Forest type } & \multicolumn{4}{|c|}{ Stand-size class } & \multirow{2}{*}{$\begin{array}{l}\text { All } \\
\text { classes }\end{array}$} & \multirow{2}{*}{ SE } \\
\hline & $\begin{array}{l}\text { Saw- } \\
\text { timber }\end{array}$ & $\begin{array}{l}\text { Pole- } \\
\text { timber }\end{array}$ & $\begin{array}{l}\text { Sapl ing and } \\
\text { seedl ing }\end{array}$ & $\begin{array}{l}\text { Non- } \\
\text { stocked }\end{array}$ & & \\
\hline Red pine & 17.3 & .0 & .0 & .0 & 17.3 & 100.0 \\
\hline White pine & 306.8 & .9 & .0 & .0 & 307.7 & 26.4 \\
\hline Wh: te pine/hemlock & 134.3 & 17.7 & 4.4 & .0 & 156.4 & 31.2 \\
\hline Hemlock & 246.4 & 3.4 & .0 & .0 & 249.7 & 25.4 \\
\hline White/red pine group & 704.7 & 21.9 & 4.4 & .0 & 731.1 & 15.2 \\
\hline Balsam fir & 20.8 & 3.7 & 5.0 & .0 & 29.5 & 64.6 \\
\hline Red spruce & 84.8 & .0 & .0 & .0 & 84.8 & 47.7 \\
\hline Red spruce/balsam fir & 22.0 & .0 & 2.9 & .0 & 24.9 & 74.3 \\
\hline Norway spruce & 6.5 & .0 & .0 & .0 & 6.5 & 100.0 \\
\hline Nor thern white-cedar & 5.4 & .0 & .0 & .0 & 5.4 & 100.0 \\
\hline - Spruce/fir group & 139.5 & 3.7 & 7.9 & .0 & 151.1 & 32.2 \\
\hline Wh. pine/no.red oak/wh. ash & 28.4 & 5.5 & .0 & .0 & 33.9 & 53.7 \\
\hline Oak/pine group & 28.4 & 5.5 & .0 & .0 & 33.9 & 53.7 \\
\hline Chestnut oak & 16.3 & .0 & .0 & .0 & 16.3 & 100.0 \\
\hline White oak/red oak/hickory & 33.0 & 30.6 & .0 & .0 & 63.6 & 51.0 \\
\hline Northern red oak & 57.1 & 19.5 & .0 & .0 & 76.6 & 44.9 \\
\hline Mixed central hardwoods & 136.8 & 46.5 & .0 & .0 & 183.3 & 31.1 \\
\hline Oak/hickory group & 243.2 & 96.6 & .0 & .0 & 339.8 & 21.8 \\
\hline Black ash/Amer. elm/red maple & 11.3 & .0 & .9 & .0 & 12.3 & 92.6 \\
\hline Willow & .0 & .0 & 1.1 & .0 & 1.1 & 71.1 \\
\hline American elm/green ash & .0 & 6.4 & .0 & .0 & 6.4 & 100.0 \\
\hline Elm/ash/red maple group & 11.3 & 6.4 & 2.0 & .0 & 19.8 & 65.9 \\
\hline Sugar maple/beech/yell ow birch & $1,777.0$ & 295.8 & 6.8 & & $2,079.6$ & $\begin{array}{r}6.8 \\
16.9\end{array}$ \\
\hline Red maple/nor thern hardwoods & $\begin{array}{r}391.4 \\
.0\end{array}$ & 156.4 & $\begin{array}{l}1.2 \\
2.0\end{array}$ & $\begin{array}{l}.0 \\
.0\end{array}$ & $\begin{array}{r}549.1 \\
8.0\end{array}$ & $\begin{array}{l}16.9 \\
56.7\end{array}$ \\
\hline $\begin{array}{l}\text { Pin cherry/reverting field } \\
\text { Mixed northern hardwoods }\end{array}$ & 417.0 & $\begin{array}{r}6.0 \\
138.6\end{array}$ & $\begin{array}{l}2.0 \\
4.5\end{array}$ & $\begin{array}{l}.0 \\
.0\end{array}$ & $\begin{array}{r}8.0 \\
560.7\end{array}$ & $\begin{array}{l}56.7 \\
16.7\end{array}$ \\
\hline Nor thern hardwoods group & $2,586.1$ & 596.8 & 14.5 & .0 & $3,197.4$ & 4.7 \\
\hline Aspen & 29.7 & 20.9 & 2.7 & .0 & 53.3 & 50.6 \\
\hline Paper birch & 103.0 & 33.0 & .0 & .0 & 136.1 & 35.5 \\
\hline Aspen/birch group & 132.7 & 53.9 & 2.7 & .0 & 189.4 & 28.7 \\
\hline All forest types & $3,846.0$ & 784.9 & 31.6 & .0 & $4,662.4$ & 2.9 \\
\hline SE & 4.3 & 11.3 & 34.7 & .0 & 2.9 & \\
\hline
\end{tabular}




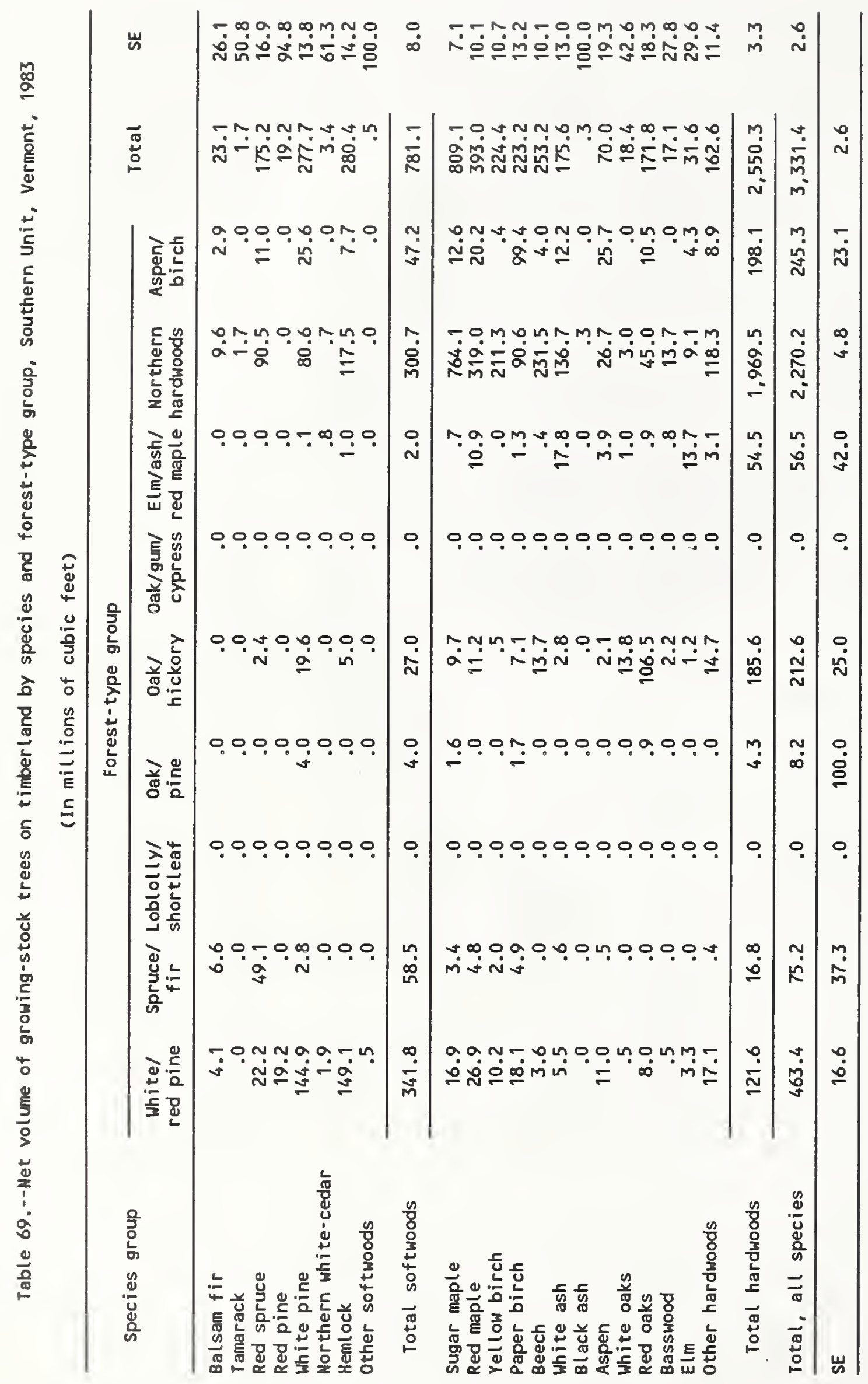




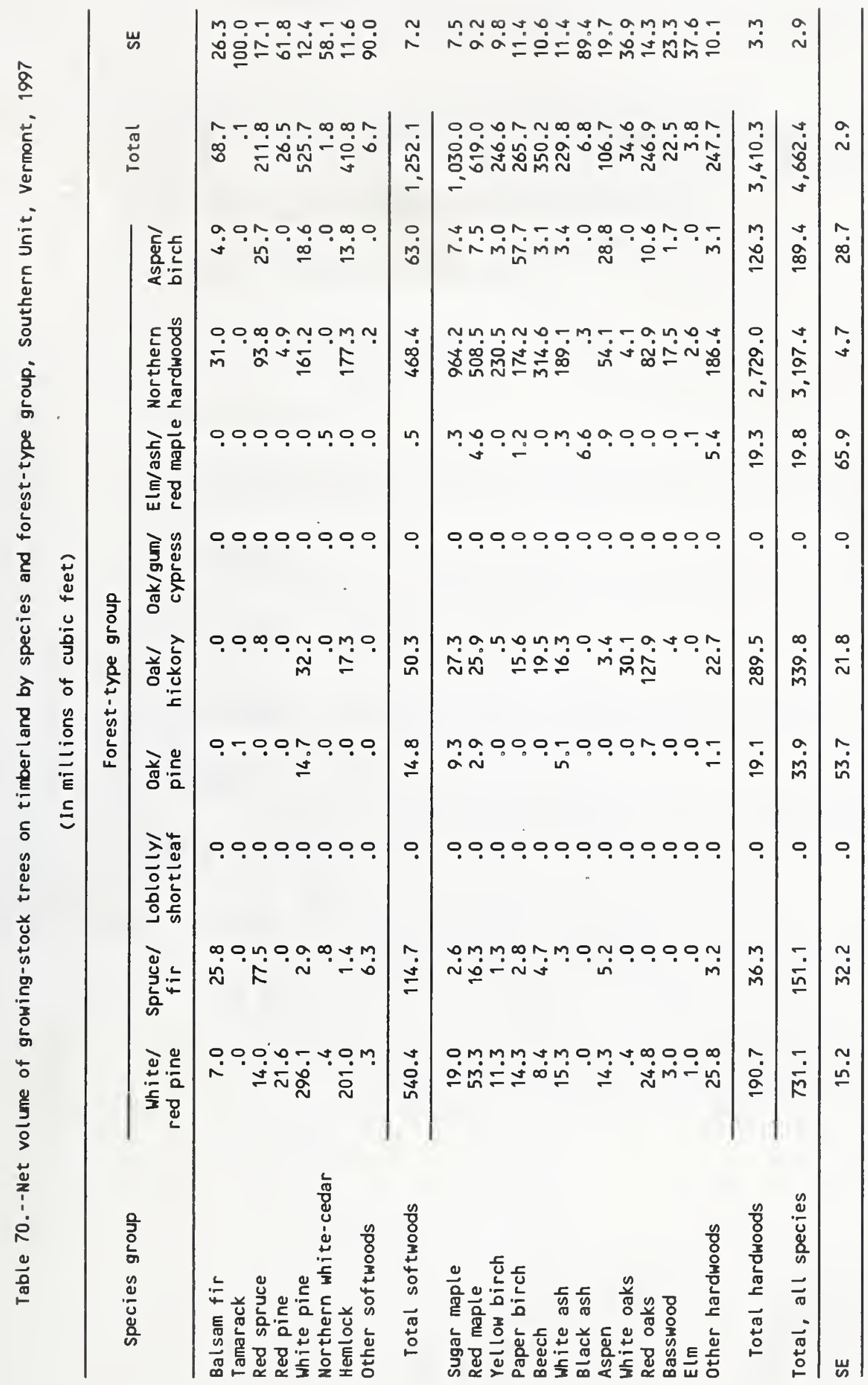




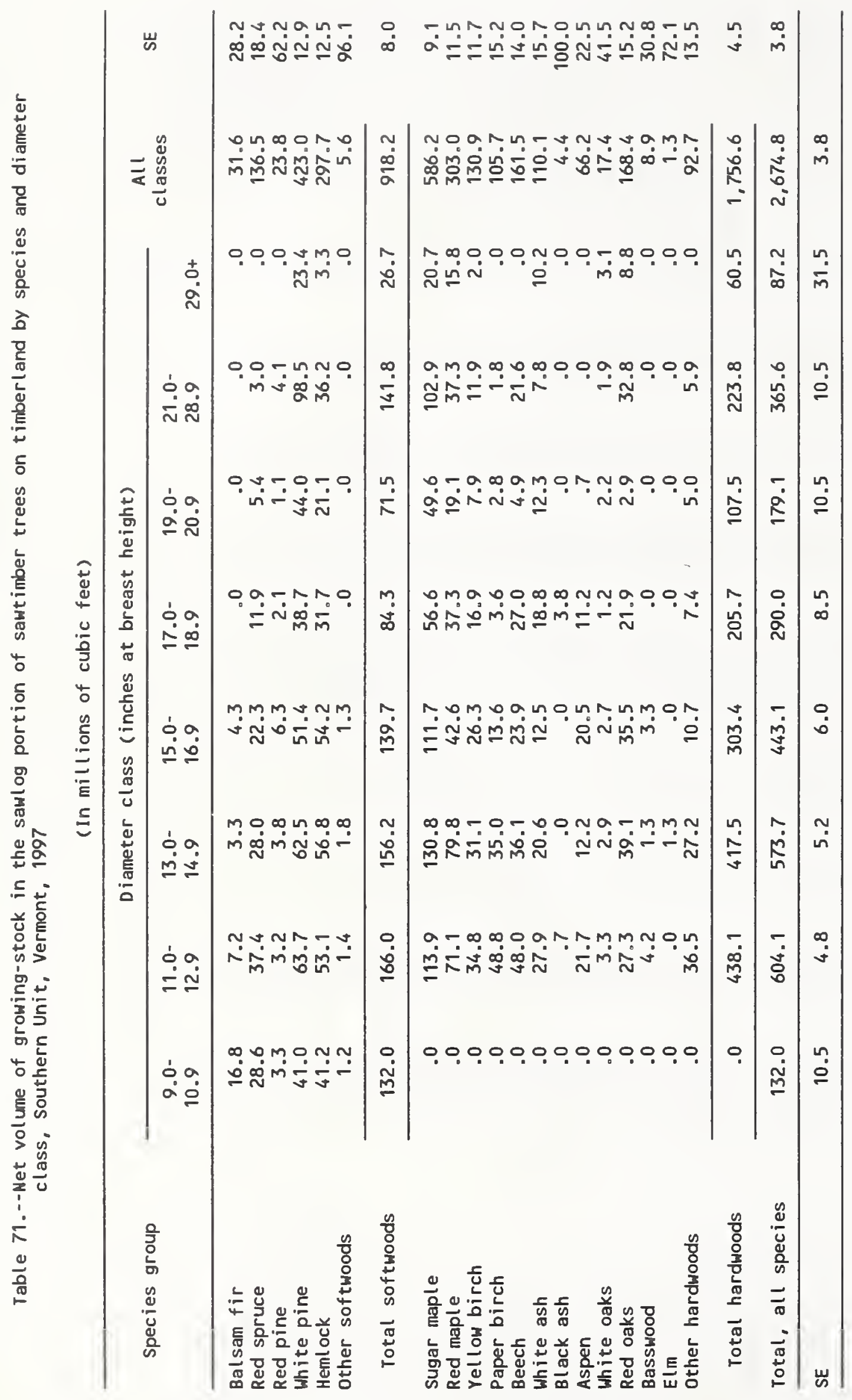


Sawtimber volume on timberland, for selected species and percent change, Southern Unit of Vermont, 1983 and 1997

(Volume increased by 58.7 percent for all species)

Sugar maple

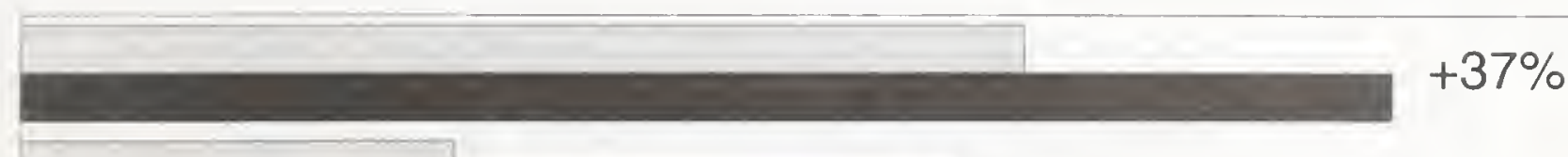

White pine

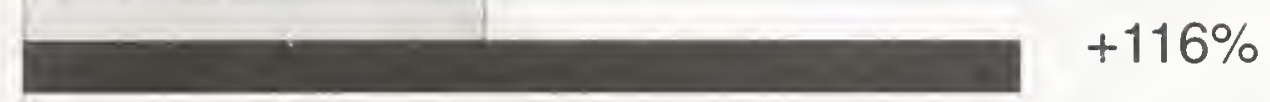

Red maple

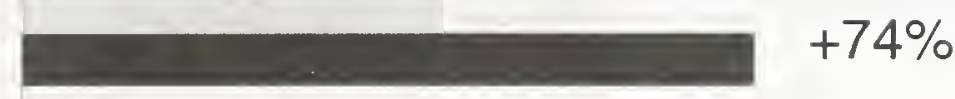

Hemlock

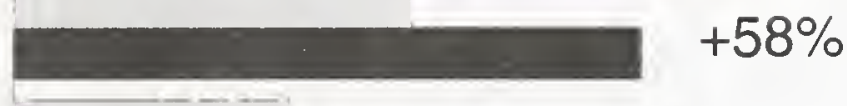

Oaks

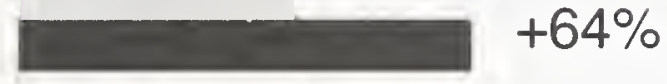

Beech

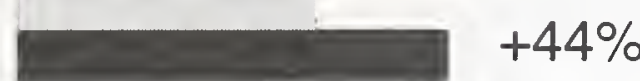

1983

Spruce

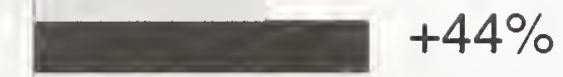

Yellow birch

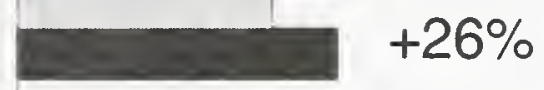

Ash

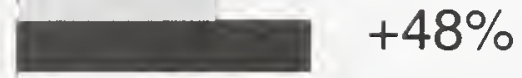

Paper birch

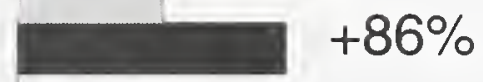

Aspen

$$
+140 \%
$$

Balsam fir

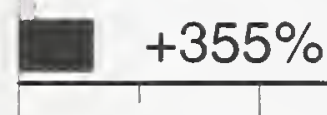

$\begin{array}{llllll}0 & 0.5 & 1 & 1.5 & 2 & 2.5 \\ & & & \text { Billions of board feet }\end{array}$ 


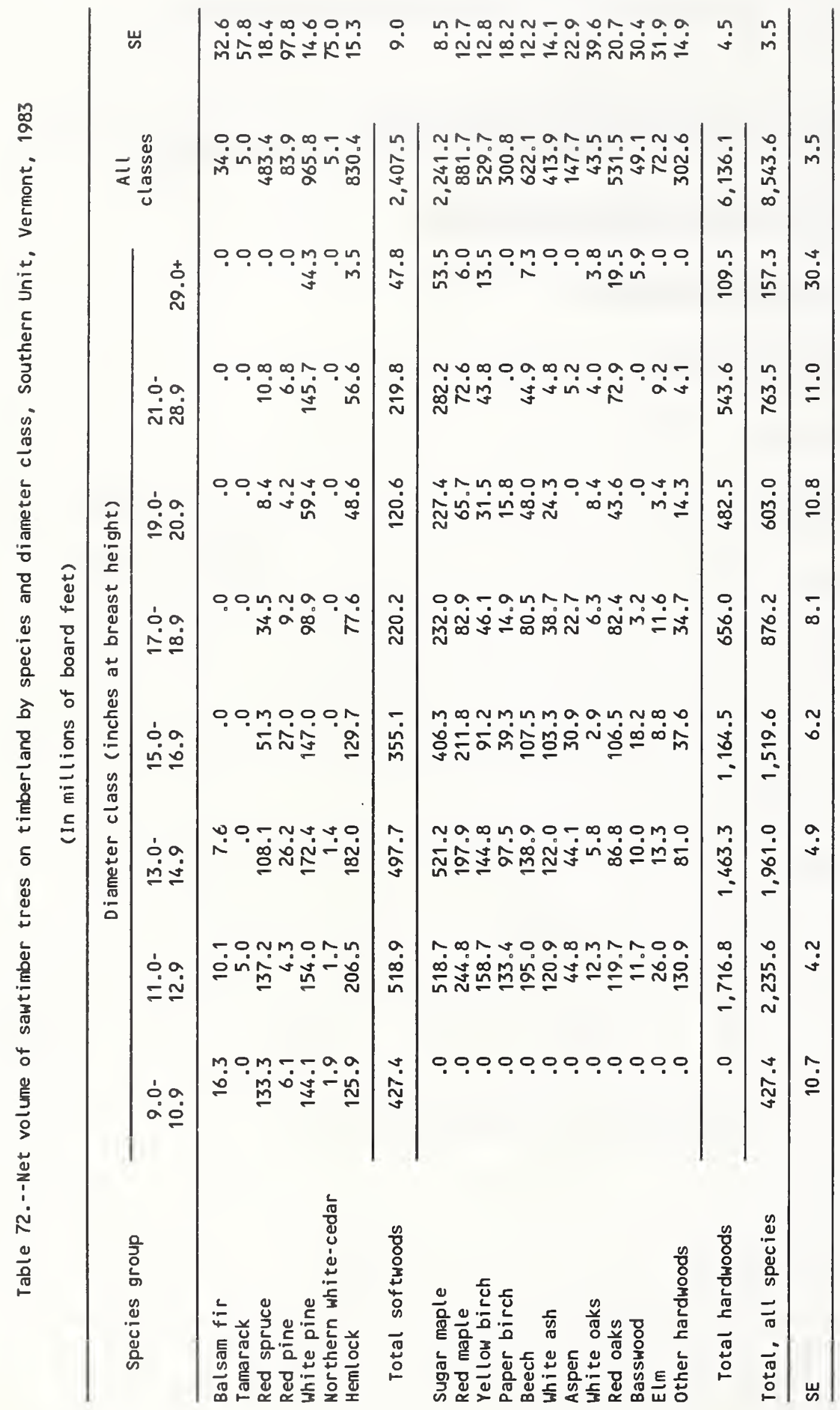




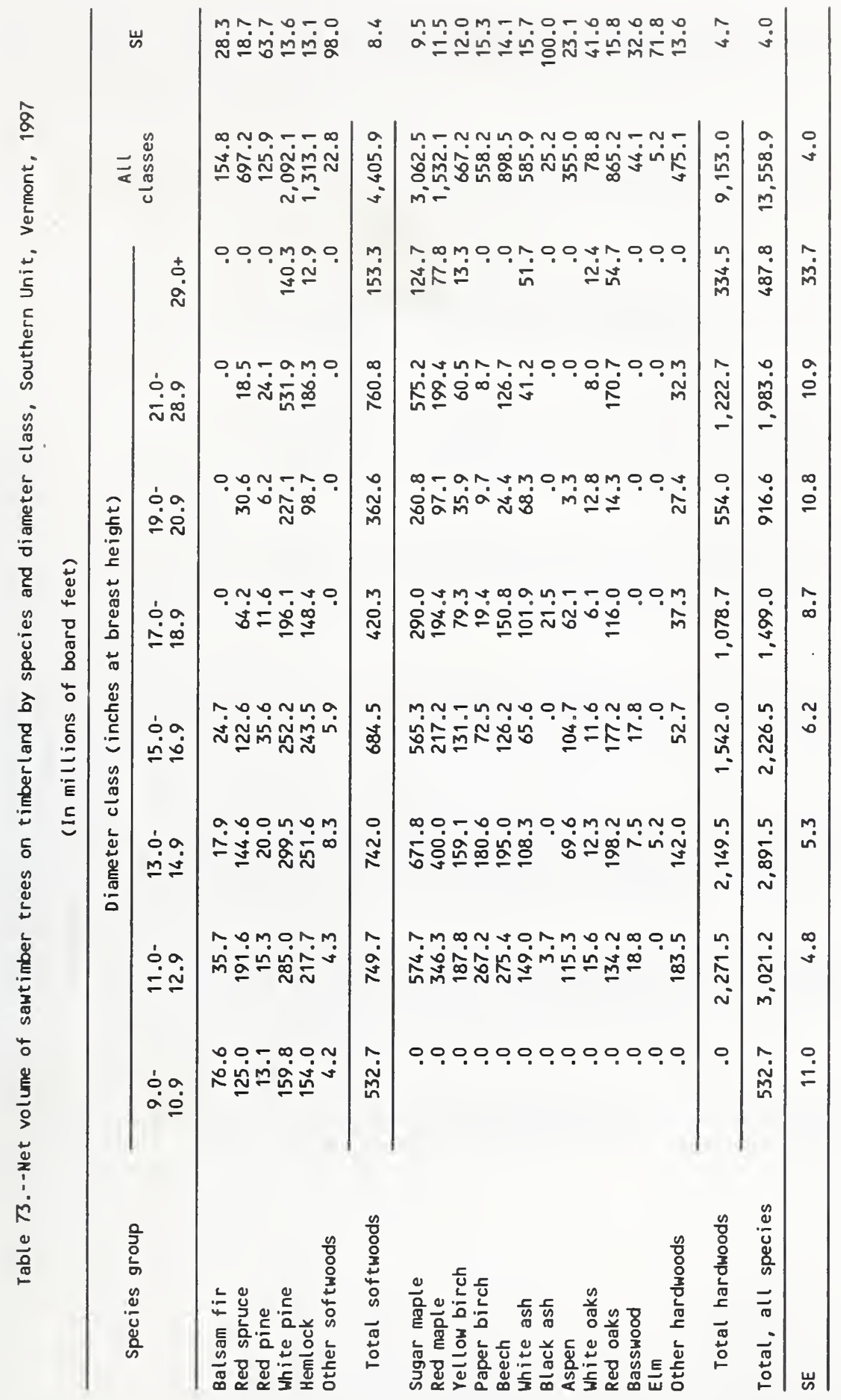




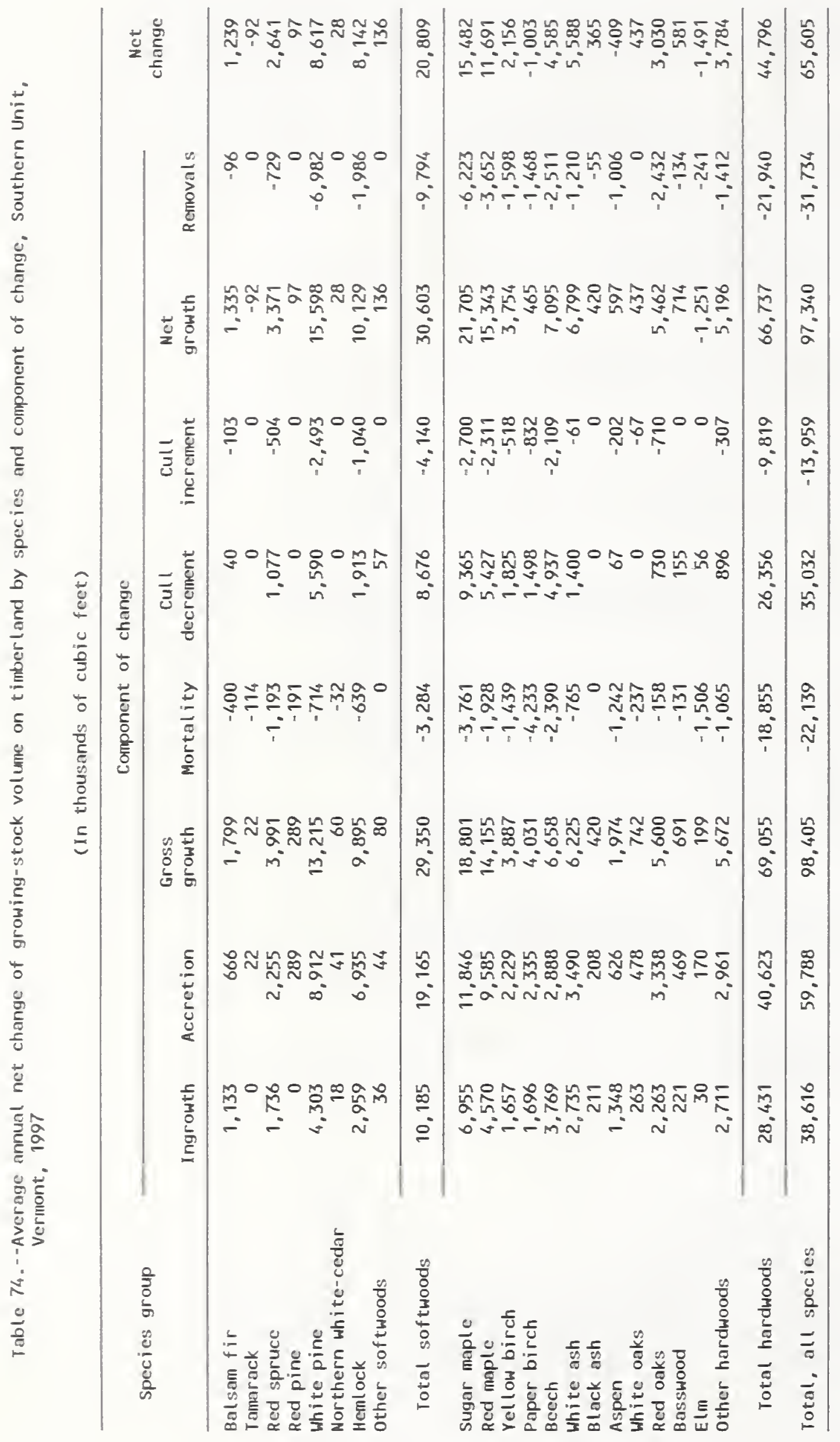




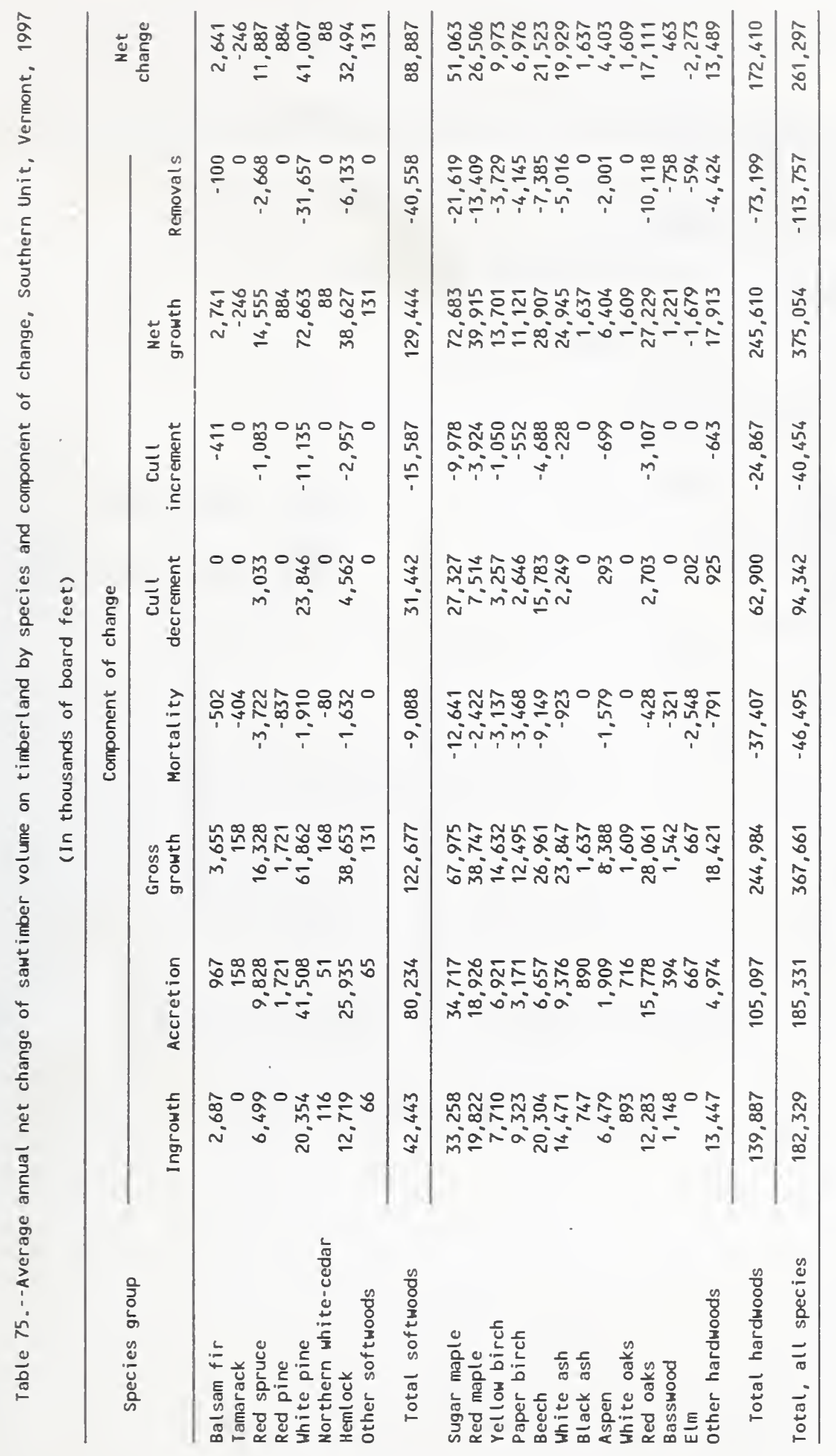


Average annual growth and removals of growing-stock volume and ratio of growth to removals for selected species on timberland, Southern Unit of Vermont, 1983-97

(Ratio of growth/removals for all species is $3.1: 1$ )

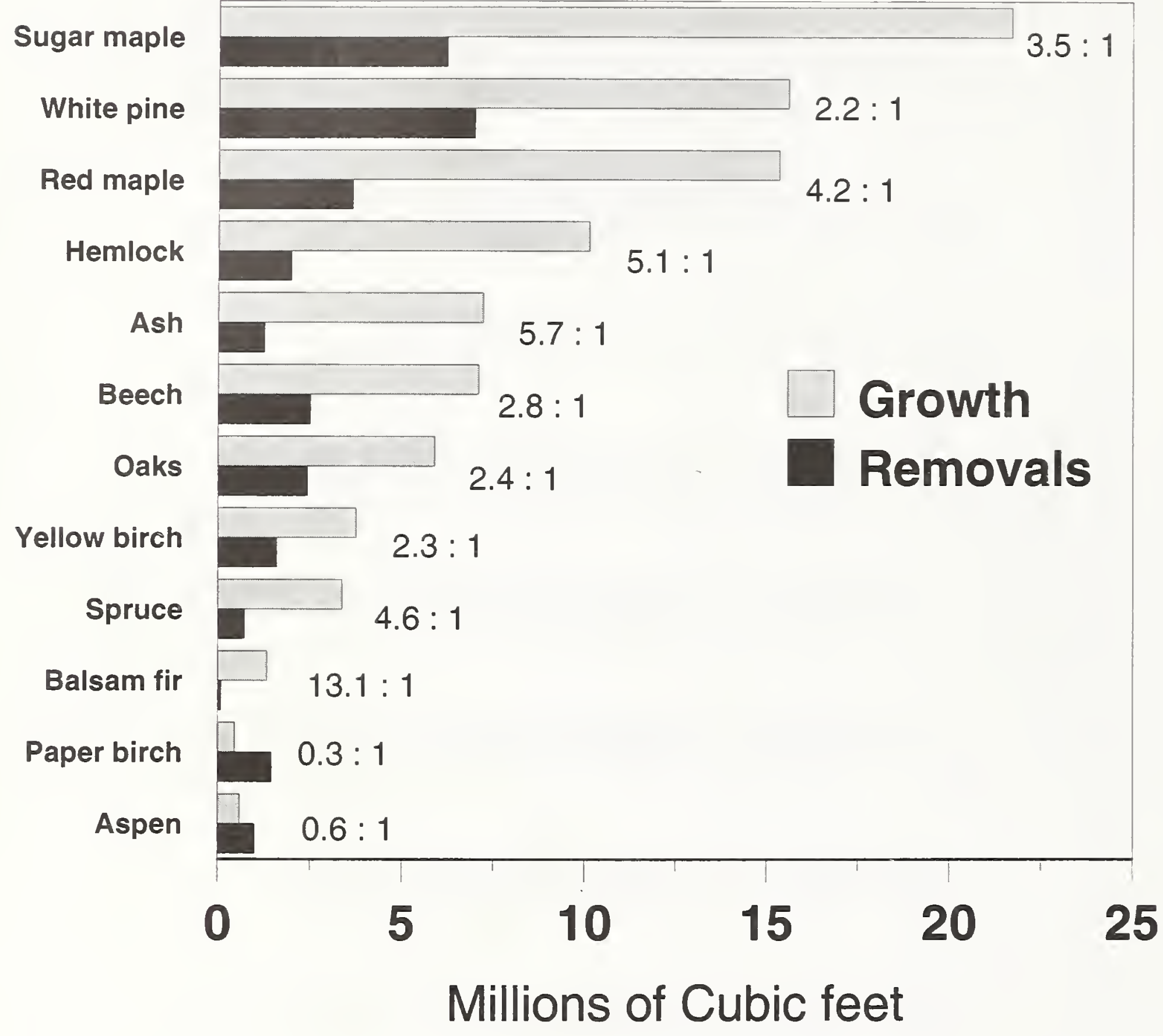




\section{COUNTY TABLES}

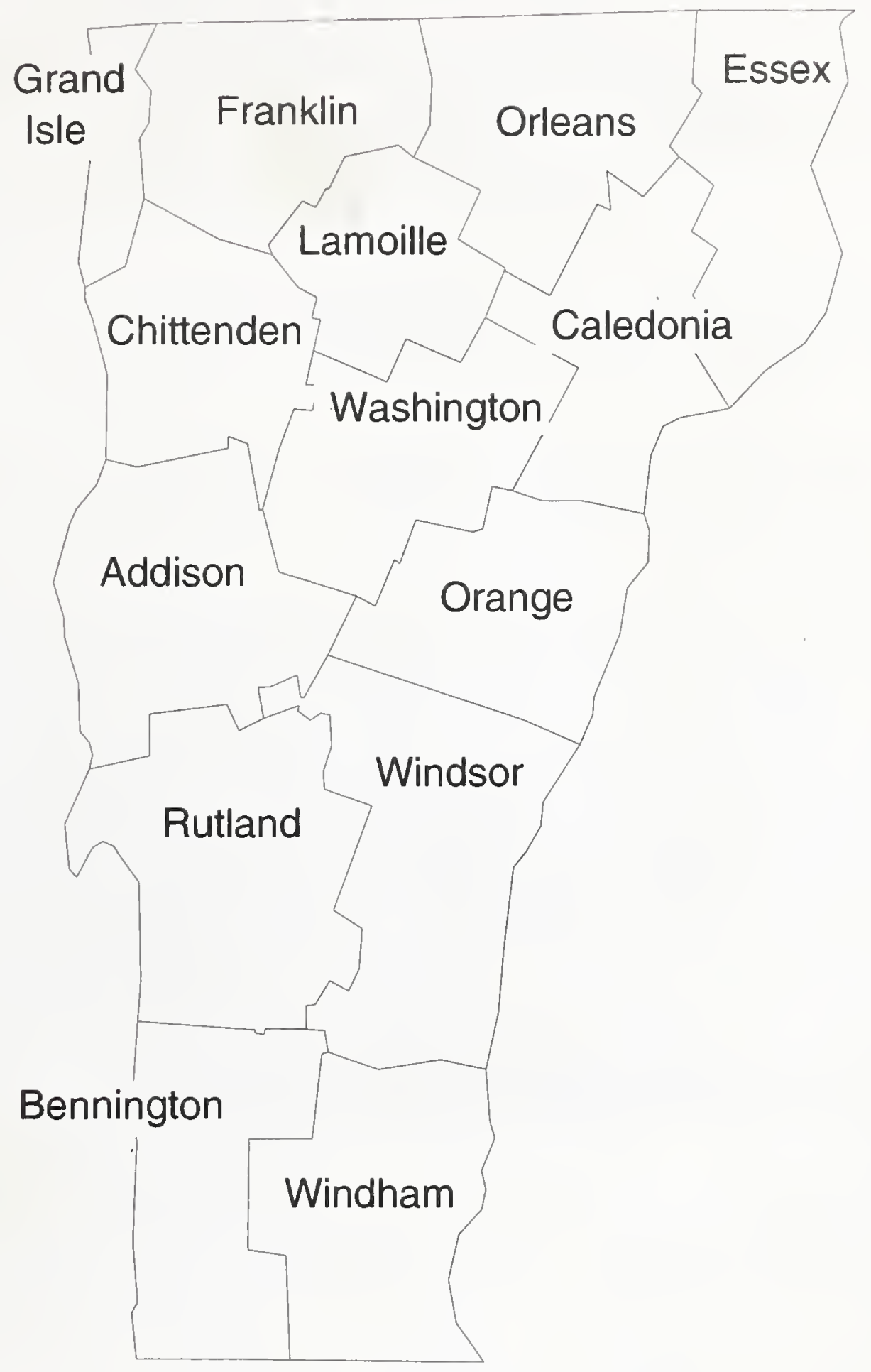




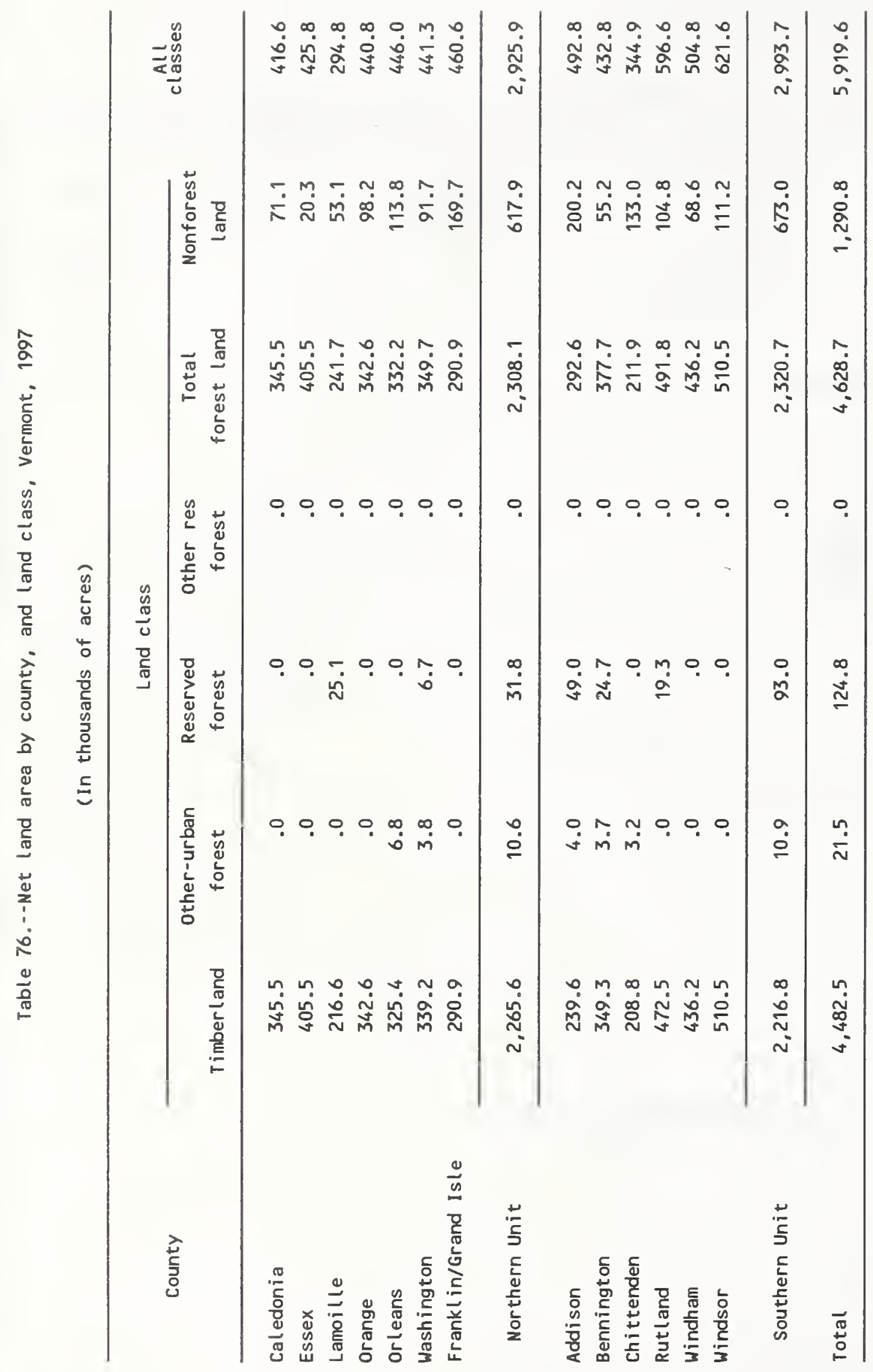




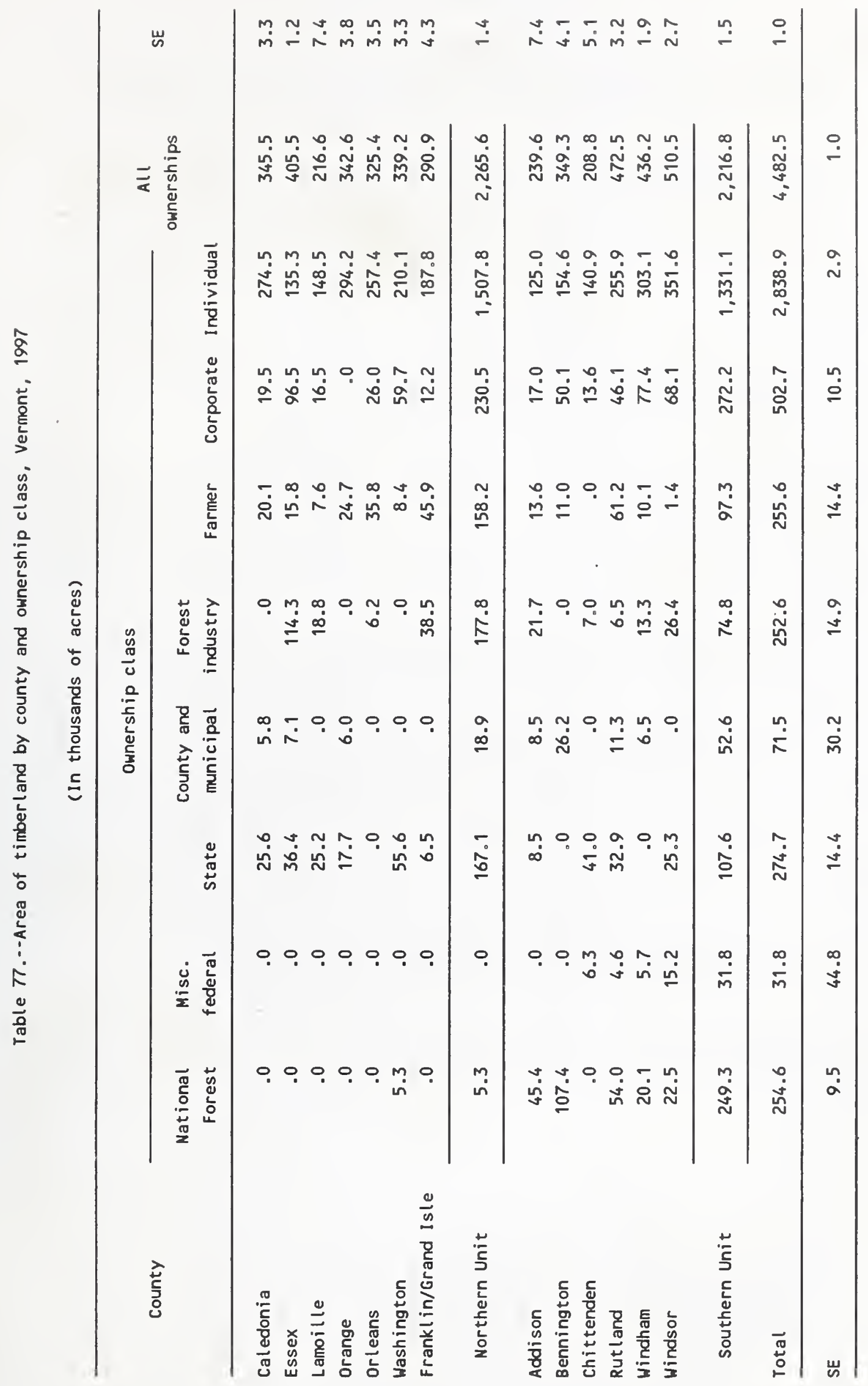




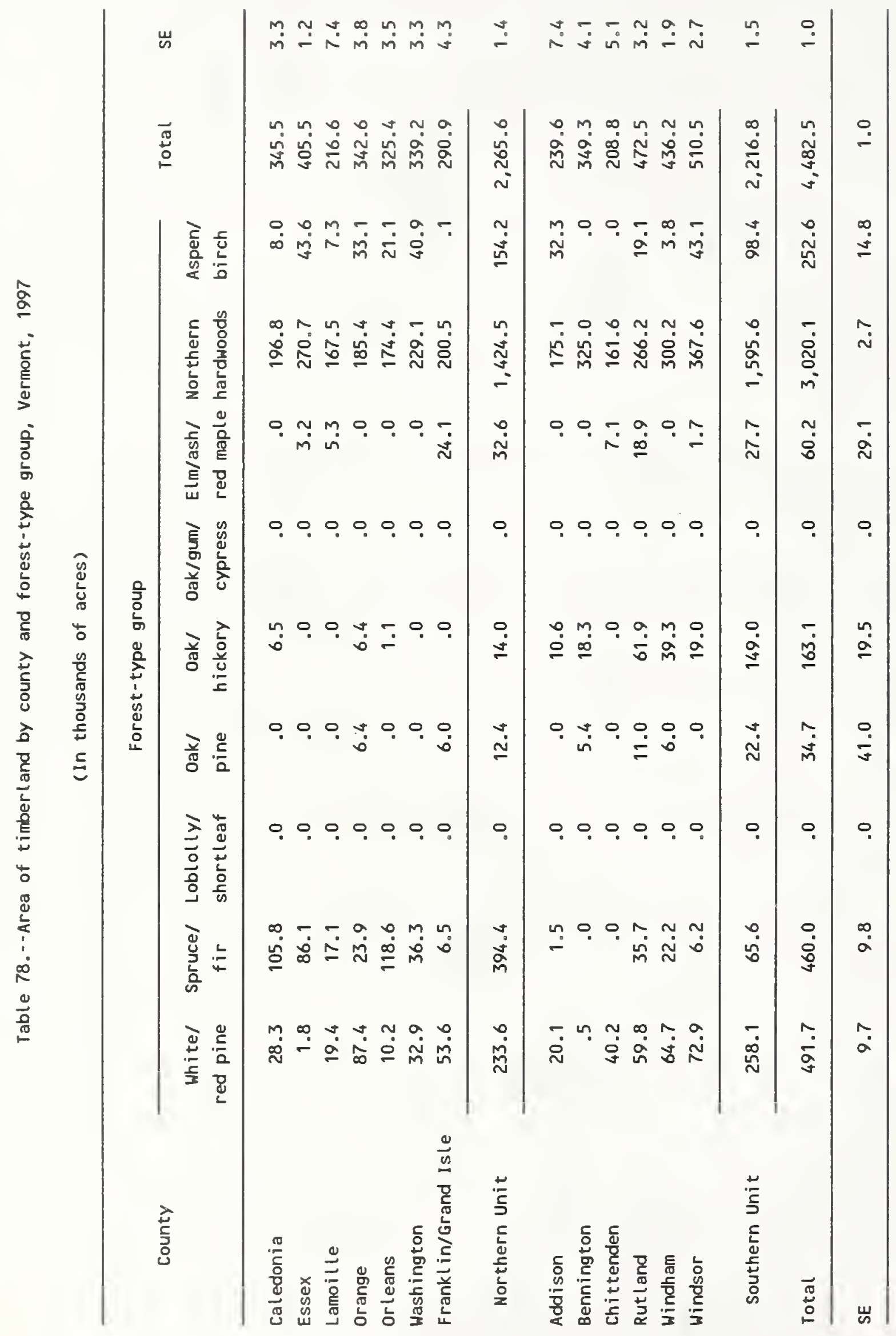


Table 79.--Area of timberland by county and stand-size class, Vermont, 1997

(In thousands of acres)

\begin{tabular}{|c|c|c|c|c|c|c|}
\hline \multirow{2}{*}{ County } & \multicolumn{4}{|c|}{ Stand-size class } & \multirow{2}{*}{$\begin{array}{c}\text { All } \\
\text { classes }\end{array}$} & \multirow{2}{*}{$\mathrm{SE}$} \\
\hline & $\begin{array}{l}\text { Saw- } \\
\text { timber }\end{array}$ & $\begin{array}{l}\text { Pole- } \\
\text { timber }\end{array}$ & $\begin{array}{l}\text { Sapl ing and } \\
\text { seedl ing }\end{array}$ & $\begin{array}{l}\text { Non- } \\
\text { stocked }\end{array}$ & & \\
\hline Caledonia & 138.0 & 111.5 & 96.0 & .0 & 345.5 & 3.3 \\
\hline Essex & 160.8 & 171.5 & 73.2 & .0 & 405.5 & 1.2 \\
\hline Lamoille & 124.9 & 82.5 & 9.2 & .0 & 216.6 & 7.4 \\
\hline Orange & 251.5 & 64.1 & 26.9 & .0 & 342.6 & 3.8 \\
\hline orleans & 148.7 & 112.0 & 64.7 & .0 & 325.4 & 3.5 \\
\hline Washington & 188.5 & 129.8 & 20.9 & .0 & 339.2 & 3.3 \\
\hline Frankl in/Grand Isle & 145.7 & 113.4 & 29.2 & 2.6 & 290.9 & 4.3 \\
\hline Northern Unit & $1,158.2$ & 784.7 & 320.1 & 2.6 & $2,265.6$ & 1.4 \\
\hline Addison & 160.8 & 63.9 & 14.9 & .0 & 239.6 & 7.4 \\
\hline Bennington & 251.5 & 95.8 & 1.5 & .5 & 349.3 & 4.1 \\
\hline Chittenden & 151.6 & 33.3 & 23.9 & .0 & 208.8 & 5.1 \\
\hline Rut land & 345.3 & 100.3 & 26.9 & .0 & 472.5 & 3.2 \\
\hline Windham & 346.2 & 67.3 & 22.7 & .0 & 436.2 & 1.9 \\
\hline Windsor & 328.4 & 151.2 & 30.8 & .0 & 510.5 & 2.7 \\
\hline Southern Unit & $1,583.7$ & 511.9 & 120.7 & .5 & $2,216.8$ & 1.5 \\
\hline Total & $2,741.9$ & $1,296.6$ & 440.8 & 3.2 & $4,482.5$ & 1.0 \\
\hline SE & 2.9 & 5.8 & 10.1 & 85.3 & 1.0 & \\
\hline
\end{tabular}


Table 80.--Area of timberland by county and stocking class of growing-stock trees, Vermont, 1997

(In thousands of acres)

\begin{tabular}{|c|c|c|c|c|c|c|c|}
\hline \multirow{2}{*}{ County } & \multicolumn{5}{|c|}{ Stocking class } & \multirow{2}{*}{$\begin{array}{c}\text { All } \\
\text { classes }\end{array}$} & \multirow{2}{*}{ SE } \\
\hline & Nonstocked & $\begin{array}{l}\text { Poorly } \\
\text { stocked }\end{array}$ & $\begin{array}{c}\text { Moderately } \\
\text { stocked }\end{array}$ & $\begin{array}{l}\text { Fully } \\
\text { stocked }\end{array}$ & $\begin{array}{l}\text { Over- } \\
\text { stocked }\end{array}$ & & \\
\hline Caledonia & 24.2 & 75.5 & 124.2 & 114.9 & 6.7 & 345.5 & 3.3 \\
\hline Essex & 22.4 & 128.6 & 114.7 & 130.9 & 8.9 & 405.5 & 1.2 \\
\hline Lamoille & .0 & 10.5 & 57.2 & 148.9 & .0 & 216.6 & 7.4 \\
\hline Orange & 6.7 & 49.5 & 92.0 & 170.5 & 23.9 & 342.6 & 3.8 \\
\hline Orleans & 11.8 & 88.3 & 151.9 & 71.8 & 1.6 & 325.4 & 3.5 \\
\hline Wash ington & 4.4 & 42.4 & 119.6 & 166.5 & 6.2 & 339.2 & 3.3 \\
\hline Franklin/Grand Isle & 2.6 & 49.7 & 142.1 & 94.6 & 1.8 & 290.9 & 4.3 \\
\hline Northern Unit & 72.0 & 444.5 & 801.8 & 898.2 & 49.1 & $2,265.6$ & 1.4 \\
\hline Addison & .0 & 35.4 & 79.0 & 119.2 & 6.1 & 239.6 & 7.4 \\
\hline Bennington & .5 & 47.6 & 112.6 & 179.1 & 9.4 & 349.3 & 4.1 \\
\hline Chittenden & 22.9 & 19.6 & 89.0 & 72.5 & 4.7 & 208.8 & 5.1 \\
\hline Rut l and & 9.8 & 82.8 & 193.0 & 172.8 & 14.1 & 472.5 & 3.2 \\
\hline Windham & .0 & 30.8 & 128.0 & 259.3 & 18.1 & 436.2 & 1.9 \\
\hline Windsor & 5.4 & 66.5 & 164.7 & 261.1 & 12.8 & 510.5 & 2.7 \\
\hline Southern Unit & 38.6 & 282.7 & 766.3 & $1,064.0$ & 65.3 & $2,216.8$ & 1.5 \\
\hline Total & 110.6 & 727.2 & $1,568.1$ & $1,962.2$ & 114.4 & $4,482.5$ & 1.0 \\
\hline SE & 22.7 & 8.1 & 5.1 & 4.1 & 21.2 & 1.0 & \\
\hline
\end{tabular}




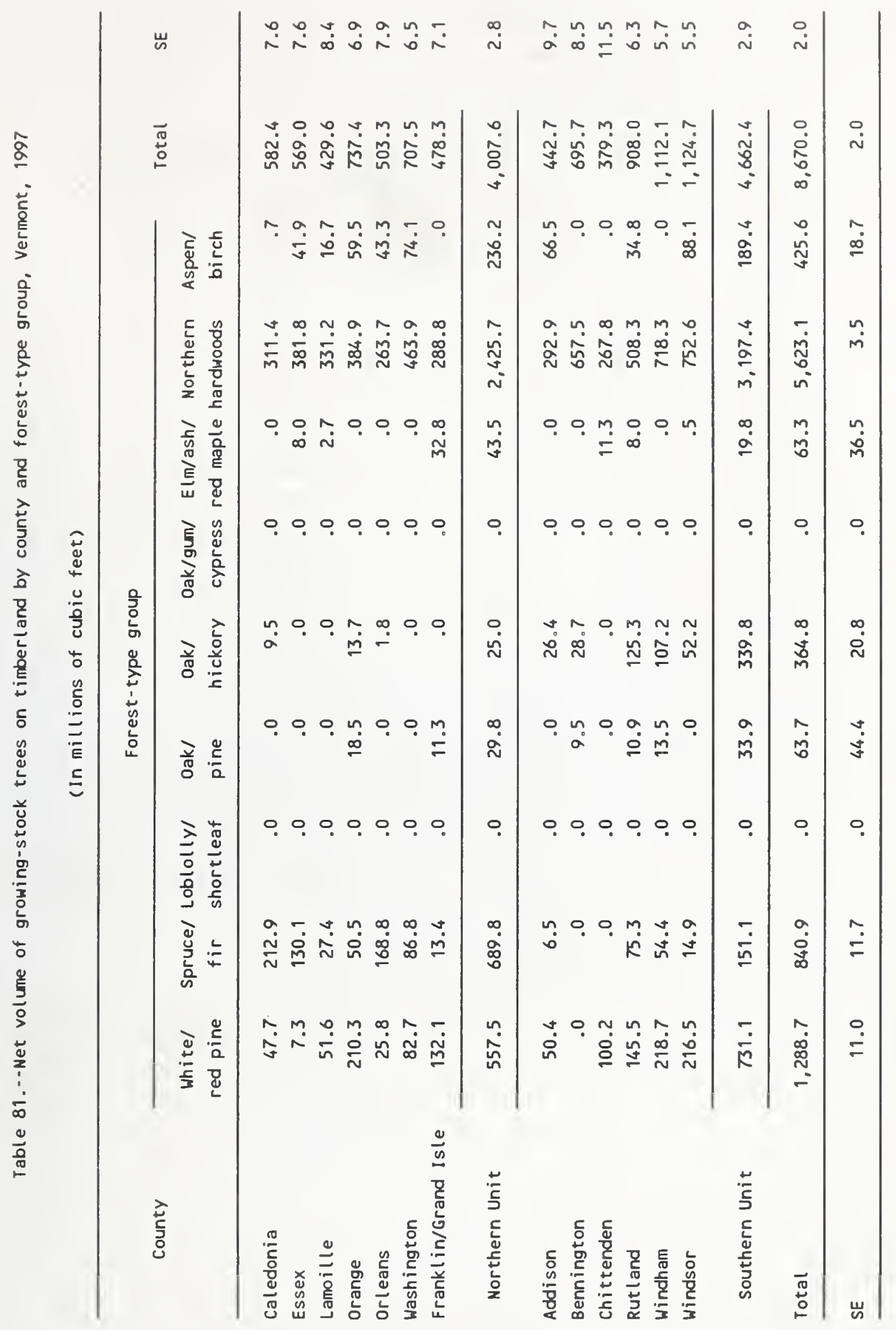


Table 82.-- Net volume of growing-stock trees on timberland by county and stand-size class, Vermont, 1997

(In millions of cubic feet)

\begin{tabular}{|c|c|c|c|c|c|c|}
\hline \multirow{2}{*}{ County } & \multicolumn{4}{|c|}{ Stand-size class } & \multirow{2}{*}{$\begin{array}{c}\text { All } \\
\text { classes }\end{array}$} & \multirow{2}{*}{ SE } \\
\hline & $\begin{array}{l}\text { Saw- } \\
\text { timber }\end{array}$ & $\begin{array}{l}\text { Pole- } \\
\text { timber }\end{array}$ & $\begin{array}{l}\text { Sapling and } \\
\text { seedling }\end{array}$ & $\begin{array}{l}\text { Non- } \\
\text { stocked }\end{array}$ & & \\
\hline Caledonia & 342.7 & 203.2 & 36.5 & .0 & 582.4 & 7.6 \\
\hline Essex & 294.8 & 251.4 & 22.8 & .0 & 569.0 & 7.6 \\
\hline Lamoille & 282.5 & 144.4 & 2.7 & .0 & 429.6 & 8.4 \\
\hline Orange & 619.0 & 114.2 & 4.2 & .0 & 737.4 & 6.9 \\
\hline Orleans & 289.0 & 190.9 & 23.4 & .0 & 503.3 & 7.9 \\
\hline Hashington & 490.4 & 209.7 & 7.4 & .0 & 707.5 & 6.5 \\
\hline Franklin/Grand Isle & 304.6 & 163.5 & 10.1 & .1 & 478.3 & 7.1 \\
\hline Northern Unit & $2,623.0$ & $1,2 \pi 7.3$ & 107.2 & .1 & $4,007.6$ & 2.8 \\
\hline Addison & 328.2 & 113.4 & 1.0 & .0 & 442.7 & 9.7 \\
\hline Bennington & 581.1 & 114.0 & .6 & .0 & 695.7 & 8.5 \\
\hline Chittenden & 341.1 & 36.9 & 1.3 & .0 & 379.3 & 11.5 \\
\hline Rut land & $\pi 59.1$ & 142.5 & 6.5 & .0 & 908.0 & 6.3 \\
\hline Windham & 992.2 & 111.6 & 8.3 & .0 & $1,112.1$ & 5.7 \\
\hline Windsor & 844.3 & 266.6 & 13.9 & .0 & $1,124.7$ & 5.5 \\
\hline Southern Unit & $3,846.0$ & 784.9 & 31.6 & .0 & $4,662.4$ & 2.9 \\
\hline Total & $6,468.9$ & $2,062.2$ & 138.8 & .1 & $8,670.0$ & 2.0 \\
\hline SE & 3.3 & 6.6 & 16.0 & 100.0 & 2.0 & \\
\hline
\end{tabular}




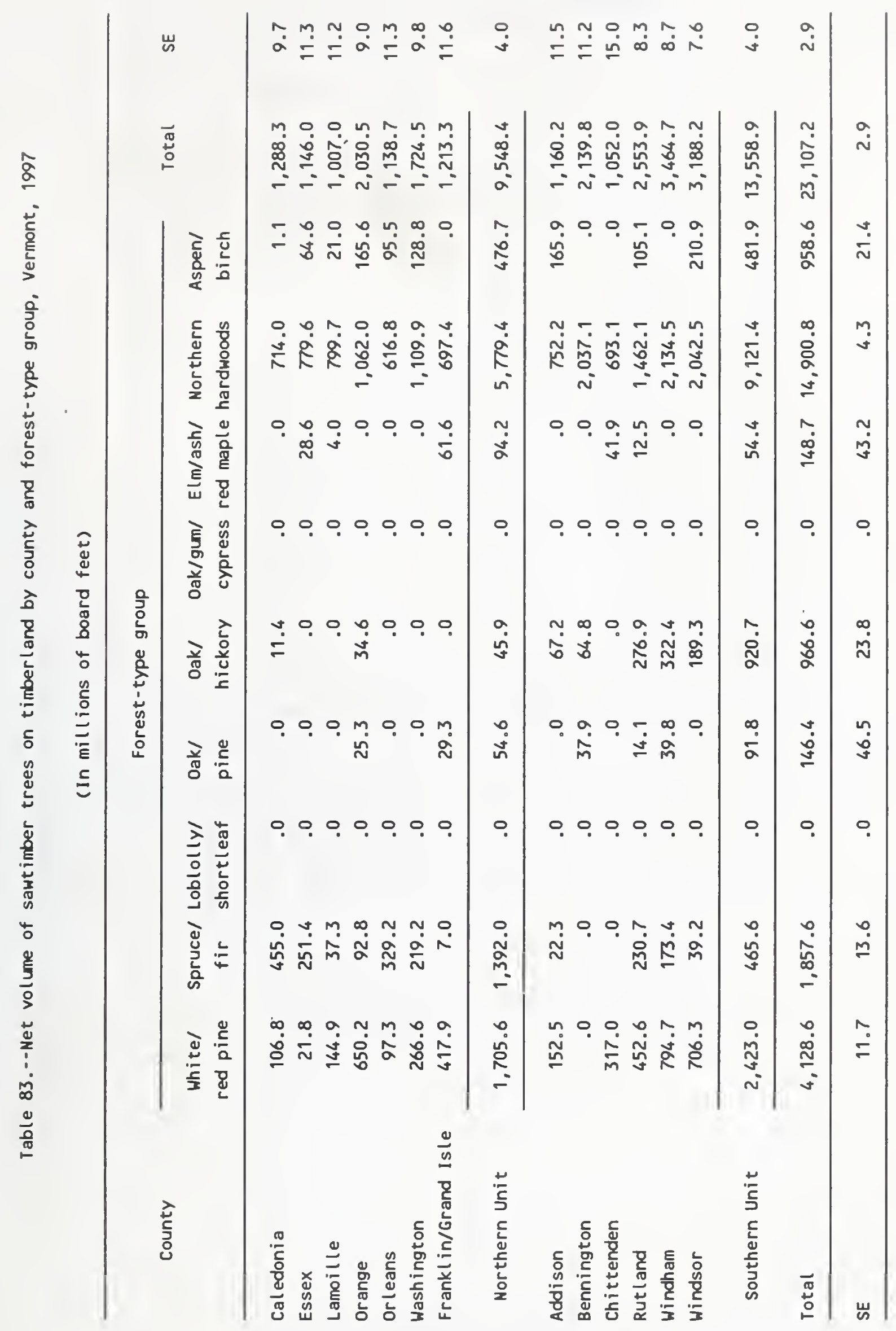


Table 84.--Net volume of sawtimber trees on timberland by county and stand-size class, Vermont, 1997

(In millions of board feet)

\begin{tabular}{|c|c|c|c|c|c|c|}
\hline \multirow{2}{*}{ County } & \multicolumn{4}{|c|}{ Stand-size class } & \multirow{2}{*}{$\begin{array}{c}\text { All } \\
\text { classes }\end{array}$} & \multirow{2}{*}{ SE } \\
\hline & $\begin{array}{l}\text { Saw- } \\
\text { timber }\end{array}$ & $\begin{array}{l}\text { Pole- } \\
\text { timber }\end{array}$ & $\begin{array}{l}\text { Sapling and } \\
\text { seedling }\end{array}$ & $\begin{array}{l}\text { Non- } \\
\text { stocked }\end{array}$ & & \\
\hline Caledonia & 892.8 & 338.4 & 57.1 & .0 & $1,288.3$ & 9.7 \\
\hline Essex & 773.4 & 342.4 & 30.2 & .0 & $1,146.0$ & 11.3 \\
\hline Lamoille & 817.5 & 185.5 & 4.0 & .0 & $1,007.0$ & 11.2 \\
\hline Orange & $1,844.8$ & 178.4 & 7.3 & .0 & $2,030.5$ & 9.0 \\
\hline Orleans & 821.9 & 279.8 & 37.0 & .0 & $1,138.7$ & 11.3 \\
\hline Washington & $1,392.8$ & 324.8 & 6.9 & .0 & $1,724.5$ & 9.8 \\
\hline Franklin/Grand Isle & 938.5 & 246.4 & 28.5 & .0 & $1,213.3$ & 11.6 \\
\hline Nor thern Unit & $7,481.7$ & $1,895.6$ & 171.1 & .0 & $9,548.4$ & 4.0 \\
\hline Addison & 939.3 & 218.5 & 2.4 & .0 & $1,160.2$ & 11.5 \\
\hline Bennington & $1,958.3$ & 181.5 & .0 & .0 & $2,139.8$ & 11.2 \\
\hline Chittenden & $1,017.1$ & 34.9 & .0 & .0 & $1,052.0$ & 15.0 \\
\hline Rut l and & $2,308.2$ & 222.6 & 23.1 & .0 & $2,553.9$ & 8.3 \\
\hline Windham & $3,262.1$ & 178.0 & 24.6 & .0 & $3,464.7$ & 8.7 \\
\hline Windsor & $2,688.9$ & 463.3 & 36.0 & .0 & $3,188.2$ & 7.6 \\
\hline Southern Unit & $12,174.0$ & $1,298.8$ & 86.1 & .0 & $13,558.9$ & 4.0 \\
\hline Total & $19,655.7$ & $3,194.4$ & 257.2 & .0 & $23,107.2$ & 2.9 \\
\hline SE & 3.7 & 7.4 & 23.4 & .0 & 2.9 & \\
\hline
\end{tabular}




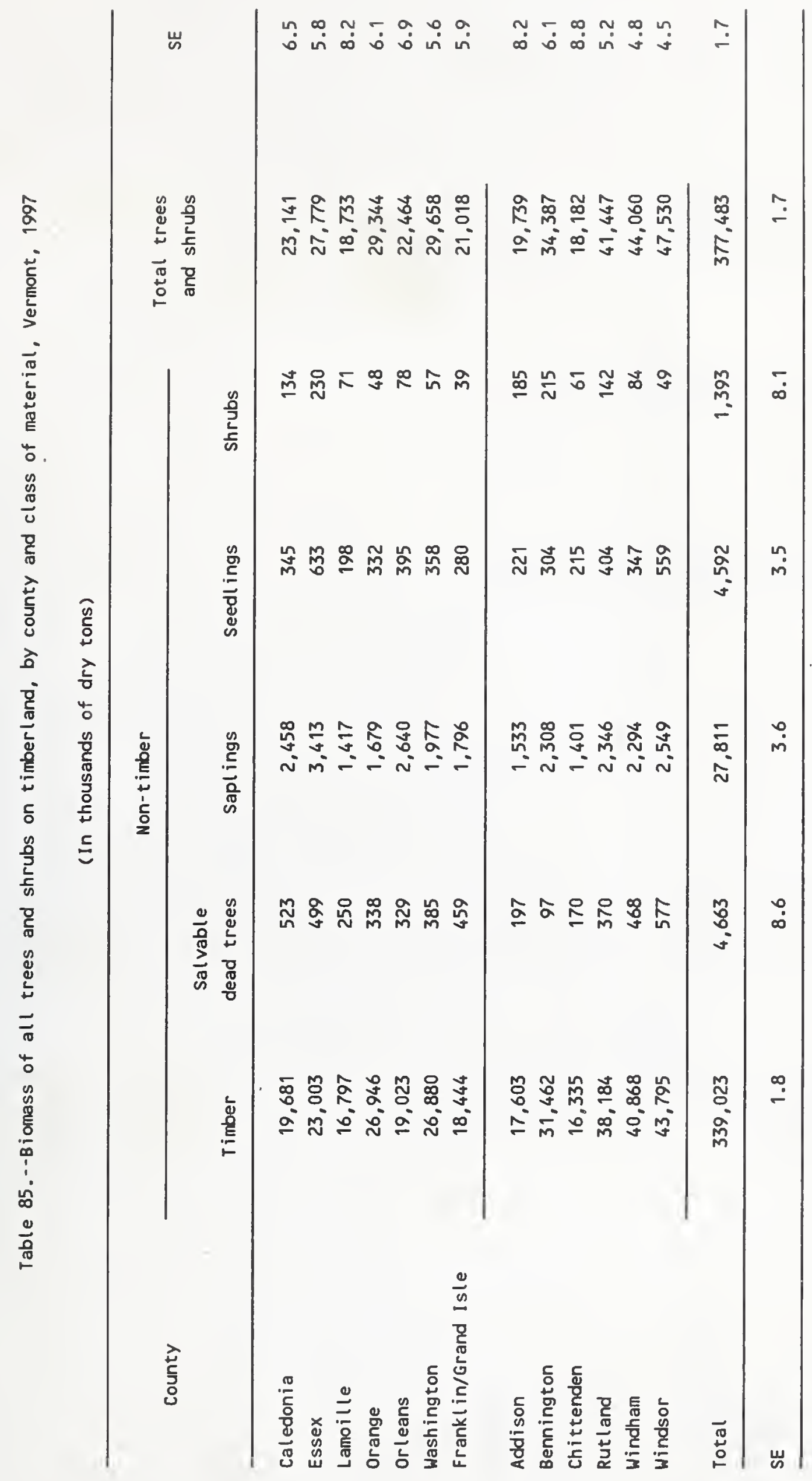




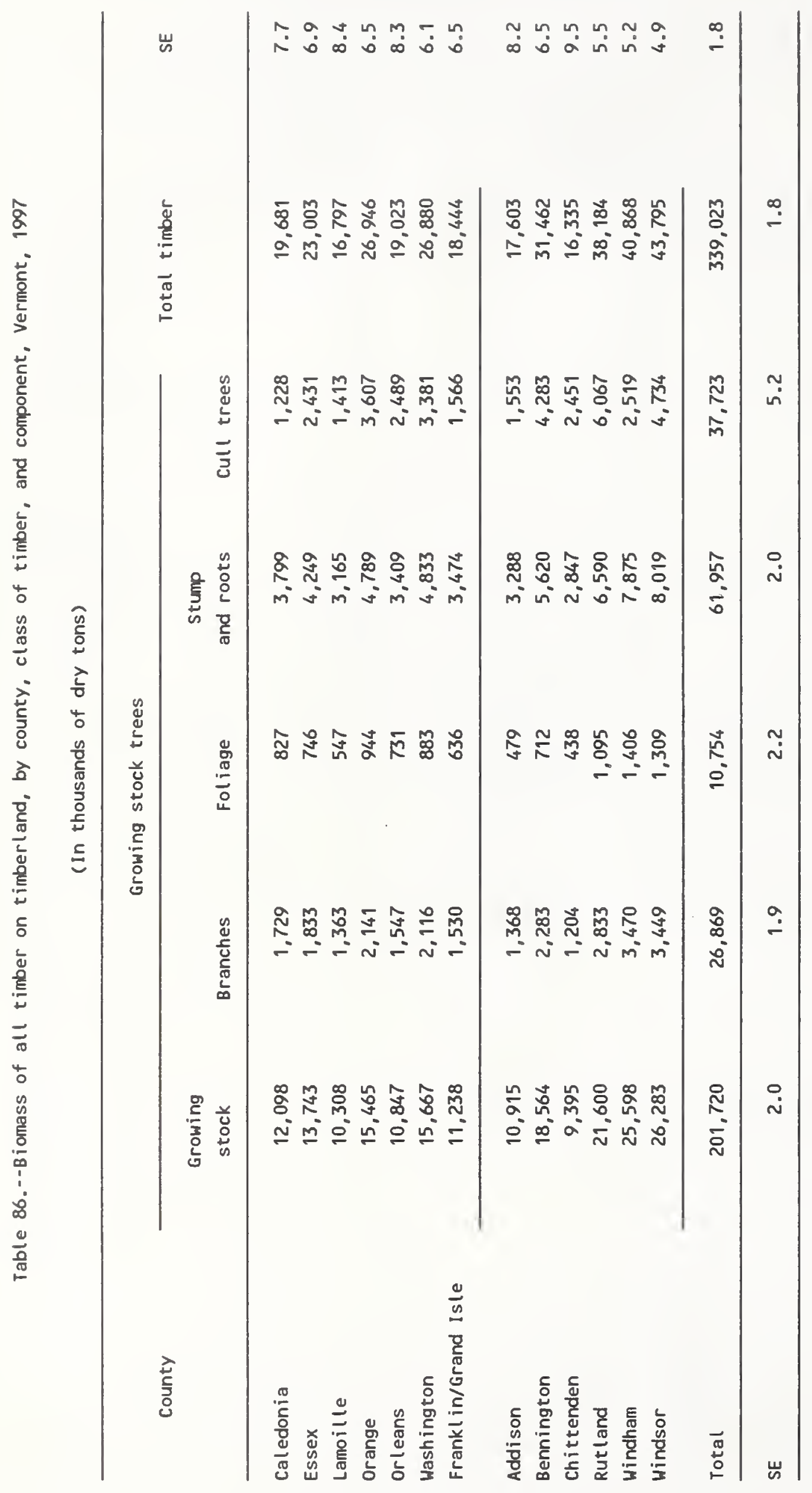




Frieswyk, Thomas S.; Widmann, Richard H. 2000. Forest statistics for Vermont: 1983 and 1997. Resour. Bull. NE-00-145. Newtown Square, PA: U.S.

Department of Agriculture, Forest Service, Northeastern Research Station. 130 p.

A statistical report on the fifth forest inventory of Vermont (1996-1998). Findings are displayed in 86 tables containing estimates of forest area, numbers of trees, timber volume, growth, change, and biomass. Data are presented at three levels: state, county, and region.

Keywords: Forest survey; inventory; area, volume; growth; change; biomass. 


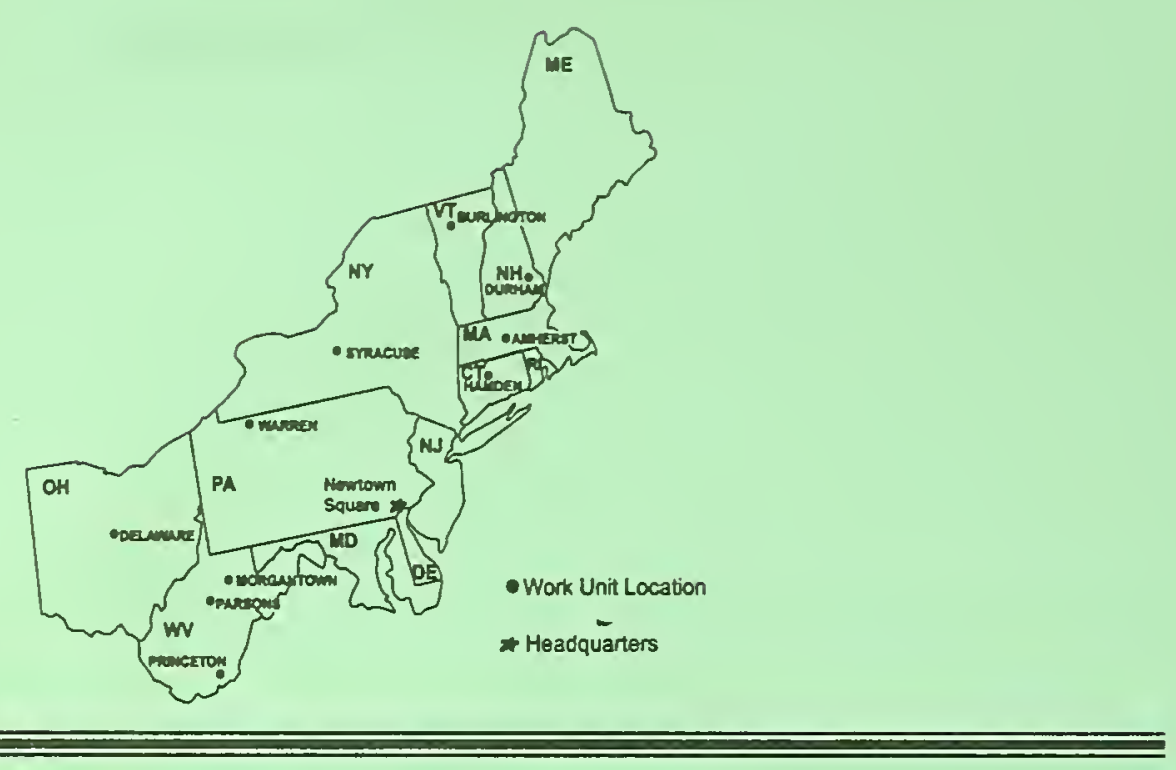

Headquarters of the Northeastern Research Station is in Newtown Square, Pennsylvania. Field laboratories are maintained at:

Amherst, Massachusetts, in cooperation with the University of Massachusetts

Burlington, Vermont, in cooperation with the University of Vermont

Delaware, Ohio

Durham, New Hampshire, in cooperation with the University of New Hampshire

Hamden, Connecticut, in cooperation with Yale University

Morgantown, West Virginia, in cooperation with West Virginia University

Parsons, West Virginia

Princeton, West Virginia

Syracuse, New York, in cooperation with the State University of New York, College of Environmental Sciences and Forestry at Syracuse University

Warren, Pennsylvania

The U. S. Department of Agriculture (USDA) prohibits discrimination in all its programs and activities on the basis of race, color, national origin, gender, religion, age, disability, political beliefs, sexual orientation, and marital or family status. (Not all prohibited bases apply to all programs.) Persons with disabilities who require alternative means for communication of program information (Braille, large print, audiotape, etc.) should contact the USDA's TARGET Center at (202)720-2600 (voice and TDD).

To file a complaint of discrimination, write USDA, Director, Office of Civil Rights, Room 326-W, Whitten Building, 14th and Independence Avenue SW, Washington, DC 20250-9410, or call (202)720-5964 (voice and TDD). USDA is an equal opportunity provider and employer. 